NEIDE HISSAE NAGAE

\title{
DE KATAI A DAZAI: APONTAMENTOS PARA UMA MORFOLOGIA DO ROMANCE DO EU
}

Tese apresentada como exigência parcial para obtenção do Grau de Doutor em Teoria Literária e Literatura Comparada à Comissão Julgadora da Faculdade de Filosofia, Letras e Ciências Humanas da Universidade de São Paulo, sob orientação do Prof. Dr. Homero Freitas de Andrade.

FACULDADE DE FILOSOFIA, LETRAS E CIÊNCIAS HUMANAS UNIVERSIDADE DE SÃO PAULO

São Paulo - 2006 


\section{AGRADECIMENTOS}

A realização deste trabalho só foi possível com o apoio e o incentivo, a compreensão e a colaboração e, acima de tudo, o carinho de pessoas preciosas que acompanharam a minha trajetória, e é com o mais profundo reconhecimento que agradeço a todos, em especial:

Ao Prof. Dr. Homero Freitas de Andrade, meu orientador, que em todos os momentos soube me conduzir com sabedoria, dedicação e paciência;

Aos Professores e funcionários do Departamento de Letras Modernas da Faculdade de Ciências e Letras da Universidade Estadual Paulista "Júlio de Mesquita Filho", Campus de Assis;

Aos Professores e funcionários do Departamento de Teoria Literária e Literatura Comparada da Faculdade de Filosofia, Letras e Ciências Humanas da Universidade de São Paulo;

Aos Professores e funcionários do Centro de Estudos Japoneses da Universidade de São Paulo;

Às amigas e colegas da Área de Japonês da UNESP, Cecília Kimie, Eliza Atsuko e Mônica Setuyo;

À Milana Satie, que auxiliou na elaboração de parte do Apêndice, à Graziela e Ana Luiza pela leitura do trabalho.

Aos meus familiares;

Aos meus pais Ricardo (in memorian) e Olga;

E ao meu marido Kunio e às minhas filhas Charlene, Susana e Jéssica a quem dedico estas páginas. 
De Katai a Dazai: Apontamentos para uma Morfologia do Romance do Eu

Página de Avaliação 


\section{SUMÁRIO}

APRESENTAÇÃO

CAPÍTULO I

O SURGIMENTO DO ROMANCE DO EU

NA LITERATURA JAPONESA.

CAPÍTULO II

TIPOLOGIA DO ROMANCE DO EU.......................................... 34

Narrador e protagonistas.......................................... 36

Narrador e foco narrativo.......................................... 62

Vida Pessoal, representação literária, verossimilhança $\quad 71$

\section{CAPÍTULO III}

PÔR-DO-SOL DE DAZAI OSAMU

— PARA ALÉM DOS HORIZONTES DO ROMANCE DO EU...

CONCLUSÃO

BIBLIOGRAFIA..

APÊNDICE

A prosa japonesa e as influências estrangeiras

ANEXOS

Imagem 1

Imagem 2

Imagem 3 


\section{RESUMO}

O presente trabalho constitui um estudo sobre um conjunto de obras pertencentes ao gênero japonês de cunho autobiográfico denominado Romance do Eu, com o intuito de traçar características comuns a essas obras que sirvam como apontamentos para uma morfologia desse gênero surgido no início do século XX.

Num primeiro momento, situamos o Romance do Eu no contexto históricoliterário do Japão e apresentamos as discussões de estudiosos japoneses na fase inicial de desenvolvimento dessa forma literária, além da visão de dois estudiosos estrangeiros sobre o gênero. Nesse percurso, traçamos ligações entre as obras estudadas com a repressão ideológica e o exercício da liberdade de expressão na postura acuada e resignada dos protagonistas, encontradas num conjunto de obras analisadas num segundo momento, que vão desde 1906, com a obra Futon (Acolchoado), de Tayama Katai, até o final da Segunda Guerra Mundial. Tais obras revelaram uma sensível e rica diversidade quando analisadas pelos elementos da narrativa que estruturam o texto, mas não foi possível encontrar textualmente aspectos que identificassem o protagonista da obra com seu autor. Na realidade, elas se mostraram uma forma velada de contestação ao sistema autoritário do Japão ao centrarem seu conteúdo em fatos da vida pessoal do autor e parodiarem os romances europeus introduzidos na época. Esse dialogismo do Romance do Eu desenvolve-se também no nível textual da obra de Dazai Osamu, intitulada Pôr-do-Sol, escrita em 1947, logo após a rendição do Japão e ainda sob a ocupação das tropas norteamericanas, incumbidas de iniciar a democratização do país. O estudo desenvolvido nesse terceiro momento mostra que o autor utiliza, ainda, outras formas literárias que privilegiaram a ficção na literatura japonesa, elabora personagens que são desdobramentos de si mesmo e que dialogam entre si e faz uso de diferentes formas narrativas, que se mesclam à intertextualidade de obras japonesas e ocidentais, criando, assim, uma obra que dispensa o rótulo de Romance do Eu e assegura a sobrevivência dessa forma narrativa na prosa moderna do Japão. 


\section{ABSTRACT}

From Katai to Dazai: Notes for Morphology of the Novel of the Self consists of a study on a set of literary works belonging to the autobiographical character Japanese genre denominated Novel of the Self, aiming at outlining common characteristics to these works that serve as notes for a morphology of this genre started in the beginning of the XX century.

In a first instance the Novel of the Self is placed in the Japanese historicalliterary context and the discussions of Japanese scholars in the initial development phase of this literary form are presented, as well as the vision of two foreign scholars about the genre.

In this trajectory are outlined connections of the works studied with the ideological repression and the exercise of the freedom of expression in the cornered and acquiescent posture of protagonists, being these connections found in a set of works analyzed in a second instance, comprehending 1906 with the work of Futon (Quilt) by Tayama Katai, up to the end of the Second World War.

Such works have revealed an insightful and rich diversity when analyzed by the elements of the narrative which structure the text, but aspects that could identify the work's protagonist with its author have not been possible to find textually.

As a matter of fact, they have revealed a veiled way of contest to the Japan's authoritative way as they have focused their content on facts of the author's personal life and parodied the European novels introduced at that time.

This dialogism in the Novel of the Self is also developed on the textual level of the work of Dazai Osamu entitled Sunset, written in 1947, right after the surrender of Japan while under the occupation of the American troops charged with the task of beginning the country’s democratization.

The study developed in this third instance reveals that the author uses, in addition, other literary forms that benefit the fiction in the Japanese literature, makes up characters that are developments of himself and that also talk among themselves, and makes use of different forms of narratives that merge to the intertextuality of Japanese and Western works, creating, as a result, a work that excuses the label of Novel of the Self and, assures the endurance of this narrative form in the Japans modern prose. 


\section{APRESENTAÇÃO}

Neste trabalho desenvolve-se um estudo sobre a narrativa de ficção de inspiração autobiográfica conhecida no âmbito da Literatura Japonesa como Watakushi Shōsetsu, ou Shishōsetsu, e que doravante chamaremos de Romance do $\mathrm{Eu}$. Visando encontrar características comuns ao conjunto de obras assim designadas e que sirvam de apontamentos para uma morfologia desse gênero, delimitamos nossa pesquisa às obras que surgiram entre o início do século XX, consideradas inaugurais, e os primeiros anos do pós-Segunda Guerra Mundial, começando pela obra Futon (Edredon, 1906), de Katai Tayama, e terminando em Shayō (Pôr-do-Sol, 1947), de Osamu Dazai.

Watakushi Shōsetsu, que também permite a leitura de Shishōsetsu em função da leitura opcional dos ideogramas que o compõem, é uma expressão que surgiu por volta de 1920. Watakushi significa "eu" e designa a primeira pessoa do singular com uma denotação de modéstia. O termo Shōsetsu significa, literalmente, "história pequena", e foi utilizado pela primeira vez em 1885, pelo estudioso Tsubouchi Shōyō, como tradução da palavra inglesa novel. Desde então, passou a ser utilizado também como correspondente do francês roman e do alemão Roman e, em sentido amplo, para designar várias obras narrativas. Até então, existiam outros termos, como monogatari (narrativa), sōshi (escritos), hon (livro) e bun (texto), para designar a forma em prosa. O termo "prosa" em si, que em japonês é sanbun, foi utilizado um pouco antes, em 1871, por Nishi Amane, mas apesar de já aparecer em textos chineses não era muito utilizado e só consolidou-se muito depois de shōsetsu.

Os japoneses subdividem os shōsetsu em longos (chōhen ou taiga shōsetsu), médios (chūhen) e curtos (tanpen), que poderíamos considerar grosso modo como romance, novela e conto, considerando apenas o critério da extensão e não as características internas e estruturais que são consenso nos estudos literários do Ocidente. Em geral, todos, independentemente de sua extensão, são simplesmente chamadas de shōsetsu e, embora reconheçamos que não seja um termo tão adequado, demos preferência para "romance" como seu correspondente para diferenciá-lo de 
"narrativa", que em geral é a tradução dada para as obras literárias clássicas conhecidas pelos nomes de monogatari e setsuwa.

Inicialmente, procuramos traçar um breve perfil histórico sobre as obras e os autores desse gênero, que foi uma das novidades da prosa japonesa moderna e alvo de reiteradas discussões no meio literário do Japão, no âmbito da crítica japonesa e, mais modestamente, da crítica estrangeira. Assim, acompanhamos o percurso do Romance do Eu desde o surgimento desse gênero e dessa expressão na literatura japonesa até as duas classificações mais conhecidas, formadas a partir de uma interpretação de estudiosos japoneses centrada na crise do protagonista, ou seja, na obra que descreve o processo da crise ou de sua superação. Nesse percurso, apresentamos três momentos de discussões sobre as obras da fase inicial que teriam consolidado o gênero, as discussões geradas no mundo literário em torno do Romance do Eu e a visão de estudiosos estrangeiros.

Depois de situar brevemente o Romance do Eu no universo literário japonês, procuramos traçar uma tipologia do gênero estudando algumas obras assim consideradas pelos críticos japoneses e tecendo considerações sobre seus aspectos narrativos mais significativos, com citações de alguns fragmentos das obras analisadas para ilustrá-los. Nessa busca, encontramos uma diversidade além da esperada para essas obras ditas simplórias e, por isso, tentamos mostrá-las por um prisma de elaboração artística que normalmente lhe é negado. Além de sua natureza autobiográfica, que necessita de um cotejo com a história pessoal do autor, nada foi encontrado concretamente no próprio texto que servisse para identificar o autor com a personagem principal tão mencionada pelos estudiosos japoneses e que costuma servir de base para a leitura dessas obras.

Verificamos, ainda, que os escritores japoneses merecem o crédito de terem contornado as autoridades com seu protesto silencioso e seus críticos com obras que aparentavam ser imitações malfeitas dos modelos mais modernos e valorizados do romance europeu, estando limitadas aos relatos da vida pessoal do autor. Com isso, procuramos, de um lado, inserir o Romance do Eu como um produto do contexto histórico de perseguição e censura ideológica vivida pelos japoneses desde a abertura do Japão ao Ocidente até a chamada democratização do país pelas tropas de 
ocupação norte-americana, ocasião em que a liberdade de expressão é assegurada pela constituição; de outro, mostrar que as obras pertencentes ao gênero não se restringem a narrar a vida pessoal do autor de modo simples e linear, sem nenhuma elaboração artística, e que, em seu alicerce, ocultam raízes da secular literatura japonesa.

Por fim, estudamos a obra Pôr-do-Sol, que narra a vida de uma família de nobres decadentes e foi escrita logo após o término da Segunda Guerra Mundial, quando o Japão passou por um novo período de transformações. Osamu Dazai, seu autor, é pseudônimo literário de Shūji Tsushima, o sexto filho mais novo dos rapazes dentre os dez filhos de uma rica família da nobreza rural de Tsugaru, na região nordeste do Japão. Por causa da saúde fraca de sua mãe, foi criado pela tia e pela ama-de-leite, e cresceu nesse ambiente peculiar do "narrar" dessas mulheres de uma região que é uma das poucas do Japão onde os contadores de histórias fazem parte do cotidiano do povo. Dazai deve ter sofrido desde cedo com as relações humanas, por receber um tratamento diferenciado como filho de um homem poderoso, mas também por depender financeiramente dos irmãos mais velhos e por ser mimado pela tia e por duas irmãs mais novas. Ainda jovem, Dazai participou de movimentos sociais e misturou-se à camada popular que contestava a posição de sua origem familiar, vivenciando, com isso, um conflito interior de uma pessoa sem lugar no mundo. Tentou o suicídio várias vezes, conseguindo concretizá-lo às vésperas de completar 39 anos.

Em nossa análise de Pôr-do-Sol, procuramos defendê-la como uma obra que alcança um grau de sofisticação em que o autor utiliza vários elementos em sua composição, mesclando, na obra, uma síntese de sua vida e de seus pensamentos pessoais por meio de diferentes formas narrativas e criando uma intertextualidade entre obras japonesas e ocidentais na história das quatro personagens principais, como apelo para uma nova vida da protagonista e da prosa de ficção japonesa em um novo tempo. 


\section{CAPÍTULO I}

\section{O SURGIMENTO DO ROMANCE DO EU NA LITERATURA JAPONESA}

Como quer que se traduza a expressão Watakushi Shōsetsu, ela sempre causará estranhamento ao estudioso pouco habituado à terminologia própria da literatura japonesa. Mesmo no âmbito dos estudos literários japoneses, a expressão Romance do $\mathrm{Eu}$ e mais especificamente a forma literária que ela designa provoca controvérsias entre críticos e estudiosos. Não há como negar, porém, a importância da forma no processo de modernização da prosa literária japonesa, iniciado nas primeiras décadas do século XX.

No mundo literário japonês, a expressão ${ }^{1}$ surgiu no início da década de 1920 e foi seguida por outras similares, como watakushi wa shōsetsu (eu sou o romance) e “watakushi” shōsetsu (romance do "eu”). Nessa época, os estudiosos japoneses voltaram sua atenção para as obras de cunho autobiográfico, ${ }^{2}$ preocupados que estavam com sua disseminação. Segundo esses estudiosos, a falta de preocupação dos autores com a estruturação da obra e com a criação da personagem principal, uma vez que tomavam a si mesmos como modelos, poderia causar "prejuízos" ao desenvolvimento literário japonês, pois tais obras traziam um narrador-protagonista, entendido como o próprio autor, e partiam do pressuposto de que o leitor tinha conhecimento da vida do escritor. Daí, mediante a introdução do "eu" na obra, todo o conteúdo restante deveria ser interpretado como fato verídico relativo ao autor. $\mathrm{O}$ mesmo tom de reprovação foi dirigido às obras ${ }^{3}$ pertencentes à categoria jistumei shōsetsu (romance com nome real), publicadas a partir de 1919. Eram um misto de "romance da vida real", uma espécie de registro escrito sobre a vida dos membros

\footnotetext{
${ }^{1}$ A expressão é assinada por Hirano Ken, que se baseia na pesquisa de Ogasawara Masaru e Enomoto Takashi, em Kōichi ISOTA, Shinchō Nihon Bungaku Jiten (Dicionário Shinchō de Literatura Japonesa), p.1388-1343.

${ }^{2}$ Essas obras começaram a aparecer no início do século XX.

${ }^{3}$ Podem ser citadas: Ano Koro no Jibun no Koto (Fatos Pessoais Daquela Época), de Akutagawa Ryunosuke; Tomo to Tomo no Aida (Entre Dois Amigos), de Kikuchi Kan; Ryōyū Akuyū (Bons e
} 
dos círculos literários. Seus autores acreditavam pertencer a uma elite, e despertavam nos leitores o interesse e a curiosidade pelo que diziam ou faziam, ou seja, pela vida do escritor. As críticas ao Romance do $\mathrm{Eu}$, em parte, tiveram origem nesse matiz negativo de seu histórico, associado às obras que se limitavam a descrever fatos da vida cotidiana do autor.

Assim, com o crescente número de obras que narravam a vida privada do escritor, sobretudo revelando aspectos obscuros e utilizando personagens com nomes de pessoas reais, a expressão "Romance do Eu" tornou-se tema de discussão dos círculos literários japoneses à época, inicialmente com um sentido depreciativo de romance simplório e com uma conotação discriminatória e pejorativa pela falta de elaboração formal e por problemas ligados à ficcionalidade, ao caráter ficcional.

O verbete assinado por Ino Kenji em Nihon Kindai Bungaku Daijiten (Grande Enciclopédia da Literatura Japonesa Moderna) começa expondo a dificuldade de se "definir" o Romance do $\mathrm{Eu}$, principalmente quando se trata de enquadrá-lo na idéia de romance ao estilo ocidental. Diz tratar-se de um romance de cunho autobiográfico, um romance em primeira pessoa, e para explicá-lo usa a designação alemã Ich Roman, que, no caso da literatura japonesa, mais complica do que esclarece, pois o Ich Roman é a narrativa escrita em primeira pessoa, mas que não narra necessariamente fatos da vida real de seu autor.

A principal dificuldade de se explicar a expressão decorre, no âmbito dos estudos japoneses, da confrontação da crítica e dos leitores da obra literária com acontecimentos da vida do autor.

Nesse sentido, uma das visões mais adequadas, do nosso ponto de vista, é a de Oikawa ${ }^{4}$, que coloca o Romance do Eu, com base em critérios que levam em conta a técnica narrativa, ao lado do romance de formação, do romance psicológico, do romance de idéias e do romance epistolar.

De modo geral, no entanto, a discussão em torno do que seja o Romance do Eu mistura-se com as avaliações de juízos sobre essa forma narrativa, sua origem e

Maus Amigos), de Kume Masao; Zenshin Akushin (Bons Sentimentos, Maus Sentimentos), de Satomi Ton.

${ }^{4}$ OIKAWA, Bungei Yōgo no Kiso Chishiki 88 (Conhecimentos Básicos de Termos Literários) p. 3589. 
seu desenvolvimento no processo de modernização da literatura, que resultou na versão japonesa do Naturalismo, cujas primeiras manifestações datam de 1906. O Romance do $\mathrm{Eu}$ impõe-se como gênero durante a fase experimental do assim chamado Naturalismo japonês.

Hauser diz:

O naturalismo não é uma concepção homogênea e bem definida de arte, sempre baseada na mesma idéia de natureza, mas muda com os tempos, visando sempre um objetivo especifico e imediato, preocupado sempre com uma tarefa concreta e limitando suas interpretações de vida a determinados fenômenos. Professa-se uma crença no naturalismo não porque se considere uma representação naturalista mais artística a priori do que uma estilização, mas porque se descobre na realidade um certo traço, uma certa tendência a que se gostaria de dar maior ênfase, que se gostaria de promover ou de combater. [...] O naturalismo não ter por alvo a realidade como um todo, não a "natureza" ou a "vida” em geral, mas a vida social em particular, ou seja, aquela província da realidade que se tornou especialmente importante para essa geração. ${ }^{5}$

A despeito desses estudos sobre a escola naturalista, convém ressaltar as limitações de acepção que esse movimento teve no Japão. O estudioso Nakamura Mitsuo traça, por exemplo, o perfil do Naturalismo francês como originário da influência do Positivismo e das ciências naturais e adotado na literatura em meados do século XIX, formando escritores que acreditavam que introduzir o método das ciências naturais na literatura era um meio para a pesquisa da verdade. Segundo Nakamura, ao aplicar a teoria de Claude Bernard, Zola tornou-se a figura central do Naturalismo, pregando que a psicologia e a ação humana são determinadas pela raça e pela sociedade e que o romancista deveria pesquisar a hereditariedade e o meio para apreender a verdade humana, propondo que ele saísse da observação simples para que, por meio da experiência, apreendesse a verdade do ser humano e a vida em sociedade. Cita Maupassant, Flaubert e os irmãos Goncourt como os escritores que mais exerceram influência no Japão depois de Zola.

\footnotetext{
${ }^{5}$ Arnold HAUSER, História Social da Arte e da Literatura, p. 749-51.
} 
Tentativas anteriores de utilização dos procedimentos típicos da escola naturalista foram defendidas inicialmente pelo crítico Tsubouchi Shōyō e pelo escritor Mori Ōgai, que explicitou aspectos do Naturalismo praticado por Zola, em 1889, das obras dos autores da Kenyūsha ${ }^{6}$ - que focalizaram os problemas decorrentes da industrialização e do capitalismo nos anos precedentes e posteriores à guerra sino-japonesa (1894 a 1895) — , bem como no romance social que tratava diretamente das relações do indivíduo com a sociedade. Outras influências da obra de Zola, ainda que em menor intensidade, podem ser percebidas a partir de 1897, nas obras de Tokutomi Roka, Kunikida Doppo e Shimazaki Tōson.

No prefácio de Hatsu Sugata (Primeira Silhueta, 1900) e na obra Hayari Uta (Canção da Moda, 1902), Kosugi Tengai fez uma breve explanação do método de representação realista em que apresenta a hereditariedade e o meio como condições determinantes da vida. Nagai Kafū, por sua vez, segue o mesmo caminho em Jigoku no Hana (Flores do Inferno, 1902). A procura por uma vida melhor e a revelação da natureza animal do homem moldado pela hereditariedade e pelo meio são elementos pertinentes a essas obras, que têm o objetivo de buscar a verdade do ser humano como queria Zola. Tanto para Tengai como para Kafū, o escritor francês serviu de modelo e também de pretexto para o reconhecimento do homem como parte da natureza e como ser biológico, a fim de libertá-lo da moral preestabelecida e da estética tradicional, na tentativa de separar definitivamente a literatura do moralismo e do utilitarismo que a crítica lhe atribuía como funções. Tanto é que, para o historiador literário Takagi Ichinosuke, ${ }^{7}$ o Naturalismo japonês não passou de uma imitação superficial do Naturalismo de Zola.

Já para o historiógrafo da literatura Hisamatsu Sen'ichi, não obstante a tentativa de representar o ser humano sob o enfoque da ciência e livre de maniqueísmos, sob a crença de que estariam combatendo as convenções e a hipocrisia, essas obras constituem apenas objetos de interesse da história da literatura.

\footnotetext{
${ }^{6}$ Primeira associação literária do Japão moderno formada em 1885 sob a liderança do escritor Ozaki Kōyō. V. Apêndice, p. 51.

${ }^{7}$ Ichinosuke TAKAGI, Nihon Bungaku no Rekishi (História da Literatura Japonesa, 1967), p. 351.
} 
Independentemente do recorte que faz o estudioso Nakamura Mitsuo privilegiando a influência de Zola, pode-se dizer que a escola naturalista no Japão, por meio das obras de Kunikida Doppo e Tayama Katai, desenvolveu também outros aspectos do Naturalismo europeu, pinçados nas obras de autores como Maupassant, Turguéniev e Flaubert. Pôs a "sinceridade" acima de tudo, imprimindo um sentido moral à idéia de "natureza" descoberta nos poetas românticos ingleses. No período da guerra contra a Rússia (1904 a 1906), "Naturalismo" e "Natureza" foram palavras que, baseadas numa visão positivista, penetraram em diversas camadas da sociedade japonesa e atraíram os jovens como idéias que se opunham ao poder das convenções, das formalidades e das tradições e que eram vistas como sinônimos de Verdade, Liberdade e Oposição.

O auge da escola naturalista no Japão se dá de 1908 a 1909, tendo o Romance do Eu como forma narrativa predominante. Destacam-se, nesse período, obras como Futon (Acolchoado, 1907), escrito por Tayama Katai; Haru (Primavera, 1908) de Tōson, que reforça essa tendência; Sei (Vida, 1908) também de Katai; Hōrō (Errante, 1910) de Iwano Hōmei; e Kabi (Bolor, 1912) de Tokuda Shūsei, que elaboram conteúdos recolhidos na esfera da vida privada. ${ }^{8}$

O uso e o abuso de procedimentos do Naturalismo acabaram, entretanto, gerando movimentos antinaturalistas marcados pelas obras de escritores como Izumi Kyōka, Natsume Sōseki e Mori Ōgai e das correntes estética Tanbi ${ }^{9}$, estética, e Shirakaba $^{10}$, idealista e humanista, surgidas em 1910. A hegemonia do Naturalismo durou apenas dois ou três anos, mas pode-se dizer que as críticas das tendências opostas a ele constituíram uma extensão da própria escola naturalista, o que se evidencia, por exemplo, na concepção de mundo de escritores da corrente Tanbi, de que o homem é escravo de suas paixões e sentimentos, e pela presunção dos escritores da corrente Shirakaba, que enxergaram a si mesmos como representantes da humanidade eleitos para libertar os homens. Como se pode ver por meio do estudo

\footnotetext{
${ }^{8}$ Os novos escritores, como Masamune Hakuchō, Mayama Seika e Chikamatsu Shūkō, também foram regidos pelo Romance do Eu, mas sem apresentar novidades.

${ }^{9}$ V. Apêndice, p.59-60.

${ }^{10}$ Idem, p. 56-59.
} 
das obras de escritores pertencentes a essas duas correntes, não eram grandes suas diferenças, pois elas também tinham como ponto de partida as concepções da própria escola naturalista.

A partir de 1912, percebe-se uma coexistência ou quase fusão das várias correntes na literatura; alguns anos mais tarde, a diferença artística entre Hakuchō, Tanizaki e Shiga deixa de estar na ideologia ou na escola a que pertenciam e passa a residir na individualidade de suas naturezas. Entre 1912 e 1925, várias obras representativas do Naturalismo - como Arakure (Confusão, 1915), de Shūsei; as cinco obras de Hōmei; Momoya (Infinidade de Noites, 1927) de Katai; e diversas de Hakuchō - foram escritas quando o movimento já estava supostamente terminado. Isso mostra como esse movimento desenvolveu suas possibilidades de modos diversos e por que o Romance do $\mathrm{Eu}$ foi uma das formas ideais dos escritores do período moderno e continuou deixando obras expressivas depois de 1925, como Yoakemae (Antes do Alvorecer, 1929), de Tōson; Desenho Reduzido (Shukuzu, 1941) de Shūsei; e várias obras de Hakuchō, contendo materiais de sua viagem ao exterior.

Assim, o desenvolvimento do Naturalismo confunde-se com a trajetória do Romance do Eu desde seu nascimento, ou seja, com as primeiras obras produzidas após Futon: em 1908, Haru, de Tōson, e Sei, de Katai; em 1909, Tandeki (Libertinagem), de Hōmei, e Tsuma (Esposa), de Katai; em 1910, Ie (Família), de Tōson, e Hōrō (Errante), de Hōmei.

Os historiadores e críticos literários evitam mencionar qual teria sido o primeiro Romance do Eu, possivelmente pela própria dificuldade de defini-lo e por se tentar fazê-lo mediante uma explicação de seu processo de desenvolvimento dentro da história da literatura japonesa. Pelo senso comum, Futon é tida como a primeira, mas, pela exposição acima, Haru mostra-se a mais provável, embora não haja pronunciamentos explícitos nesse sentido.

O fato é que os estudiosos utilizam uma forma de expressão diferente para citar qual seria "o Romance do Eu", que pode ser muito bem identificado ou confundido com "o primeiro", segundo a interpretação de cada qual sobre sua origem. Segundo Nakamura Mitsuo, Kabi é a obra modelo. Hirano Ken, por sua vez, defendeu que a cristalização do Romance do Eu mais representativo surge com 
Giwaku (Suspeita, 1913), de Chikamatsu Shūkō (1876-1944). Já o estudioso Odagiri Hideo atribui a esse estudioso o mérito de ter definido quando e que obra deu início ao Romance do $\mathrm{Eu}$. Reconhece-a como tal não apenas porque apresentou uma história baseada na experiência do escritor, mas porque expõe abertamente a gravidade da falha humana e sua sordidez, revelando detalhes de atos indecorosos do autor que chegam a constranger o leitor - uma obra de destruição sem propósito, impraticável por uma pessoa comum, algo que, antes dele, ninguém havia feito. Odagiri diz, porém, que o surgimento de Giwaku teve seu terreno preparado um ano antes por Kasai Zenzō, que publicou Aishiki Chichi (Meu Saudoso Pai, 1912) na revista Kiseki, e teria sido a primeira se não tivesse caído no esquecimento da crítica em razão da extinção da revista logo no primeiro ano de sua criação, e só veio a ser considerada anos mais tarde.

O Naturalismo foi visto como um movimento que liderou a vida literária japonesa por um curto período e logo dividiu o espaço com outras correntes e autores, que se opuseram ou se mantiveram alheios a ele. Mesmo assim, durante os anos seguintes obras naturalistas continuaram a ser produzidas de modo expressivo, sendo reconhecidas como parte da corrente principal, ao passo que as demais, apesar de valorizadas, continuaram como correntes secundárias. O Romance do $\mathrm{Eu}$ manteve-se como o gênero mais representativo.

As discussões sobre o Romance do Eu, como conjunto de obras literárias, tiveram início na mesma época em que surgiu a expressão que o designa, ou seja, por volta de 1920. Como já visto, a tendência do Romance do Eu se concretizou com Futon, obra naturalista de 1907 escrita por Tayama Katai, que já em 1904 - em Rokotsunaru byōsha (Uma Descrição Nua e Crua) - defendia que tudo precisava ser revelado abertamente, ser verdadeiro e natural.

Katai inspirou-se na obra ${ }^{11}$ do escritor alemão Gerhart Hauptmann para criar Futon, pondo em prática a idéia que o atormentava havia quase três anos: escrever sobre sua “Anna Mahr”, ou seja, Okada Michiyo, sua discípula de 19 anos na vida real. Para o papel de Johannes, com quem o autor se identificava, criou o 
protagonista Takenaka Tokio, pai de família desencantado com a vida de casado e escritor ainda à espera de produzir sua obra-prima; para alvo de sua paixão, a discípula Yoshiko. Nessa época, Katai acabara de voltar da guerra russo-japonesa e arriscou sua reputação com essa idéia, que lhe abriu um novo horizonte e na qual foi bem sucedido. Futon foi uma obra que marcou época.

Os comentários foram de enaltecimento e admiração pelo modo tão aberto com que o autor havia se exposto (uma atitude que até então nenhum escritor tivera ao registrar suas próprias experiências) e pela coragem de sacrificar a vida particular em prol da arte. No entanto, como não poderia deixar de ser, a obra provocou escândalo, e Katai foi ridicularizado por aqueles que entendiam a obra de arte como modelo de vida e pelos adeptos do bom senso. Estes últimos não admitiam uma revelação tão aberta, como a de Futon, sobre o desejo sexual de um homem de meiaidade, casado, com filhos e dono de grande saber e discernimento, com uma posição a preservar. Esse, porém, foi o diferencial da obra que descreveu um homem contemporâneo, revelando as minúcias de seu conflito psicológico. Depois desse feito de Katai, todos se sentiram à vontade para descrever suas próprias experiências e as de outros.

A obra causou à época um alvoroço inédito em mais de vinte anos de vida literária japonesa moderna. Shimamura Hōgetsu e mais dez escritores e críticos da Waseda Bungaku, principal revista da corrente naturalista da época, planejaram uma avaliação conjunta, e também Yosano Tekkan e outros quatro escritores da $M y \overline{o j o}$, principal revista da corrente antinaturalista. Outras revistas, como Teikoku Bungaku e Shinsei, apresentaram suas visões sobre Futon durante aproximadamente meio ano, até sua publicação como obra principal da Coletânea de Katai, em março de 1907. Mesmo depois de décadas, a obra ainda suscita discussões. ${ }^{12}$

A idéia de que não existia uma literatura tão verdadeira quanto aquela que descrevia as experiências vividas diretamente pelo autor era muito forte na época e

\footnotetext{
${ }^{11}$ Katai revela a identificação que tinha com Johannes, de Einsame Menschen (1891), obra que lhe deu a inspiração para escrever Futon, em Trinta anos de Tóquio. Cf. Katai TAYAMA, Futon; Ippeisotsu, p. 107-10.

${ }^{12}$ Tsuneo SŌMA, Kaisetsu (Explicação) In: Katai TAYAMA, Op. cit., p. 111-117.
} 
prevaleceu a imagem de que os romances como Futon representavam o Naturalismo europeu recém-introduzido.

Na interpretação de Odagiri em Watakushi Shōsetsu to Shinkyō Shōsetsu (Romance do Eu e Romance Introspectivo, 1958), a obra não se encaixava na fórmula do Romance do $\mathrm{Eu}$, em que o protagonista é o autor; por isso, viu nela a possibilidade de a prosa japonesa manifestar um espírito crítico voltando-se para outros temas, mas diz que isso não ocorreu em razão do clima de perigo e de tensão da época, pois quando o frágil ego moderno tentou se expandir, aproveitando o crescimento da auto-estima dos japoneses após a guerra com a Rússia, o Japão entrava na fase de dominação capitalista opressora, sob a qual o desejo de liberdade continuou mantido, por parte de alguns poucos intelectuais afastados da sociedade, numa esfera fechada. Os escritores estavam expostos ao risco de não obter bons resultados em suas produções por falta de preparo ideológico e de sensibilidade para apreender a essência e a estrutura da ordem dominadora que os afastava da sociedade e para confrontar o sistema cruel de censura e controle ideológico que existia desde os primeiros anos do governo Meiji (1868 a 1911).

Diante disso, a tendência de Futon, em 1907, foi confirmada por Shimazaki Tōson no ano seguinte, com Haru, obra que descreve os sofrimentos que o autor enfrentou na juventude. A tendência de escrever sobre a própria vida teve continuidade nas obras posteriores de Tōson. Em Shinsei (Renascimento, 1918), ele revela a paixão que sentia pela própria sobrinha.

Hakai (Quebra de Convenções, 1906), focaliza o preconceito social ao narrar o sofrimento do protagonista Segawa Otomatsu, que vive atormentado por ser descendente da casta das eta. ${ }^{13}$ Com essa obra, escrita um ano antes de Futon, Tōson poderia ter dado outro rumo à prosa japonesa moderna que não o do Romance do $\mathrm{Eu}$, mas ele já vivia o clima que cerceara Katai e todos os escritores que foram induzidos a transformar o romance em palco das confissões da vida privada do autor, contribuindo, assim, para consolidar o posição do Romance do Eu no meio literário.

Nakamura Mitsuo, em Nihon no Kindai Shōsetsu (Romance Moderno Japonês, 1954), interpretou que o autor pretendia revelar sua vida íntima ao usar a 
cidade interiorana onde vivera como cenário da obra, e que, nesse sentido, Hakai também demonstrava a possibilidade de o autor adotar o Romance do Eu, como de fato o fez nas obras posteriores. Diferentemente de Odagiri, Nakamura acredita que, como a literatura romântica no Japão não se desenvolveu a contento, a valorização da "realidade" associada à idéia de "natural" do romantismo tornou a "confissão" um novo caminho atraente para os escritores. Katai, por exemplo, conseguiu, com Futon, encontrar uma fórmula fácil e adequada para atender às exigências da literatura da época, enxergando a si mesmo como "natureza" e confessando os "fatos" de sua vida.

Tagaki, o historiógrafo literário já citado, também insere o Romance do $\mathrm{Eu}$ no desenvolvimento do Naturalismo japonês, afirmando que passaram a ser criadas muitas obras que descreviam a vida pessoal do autor ou a vida individual isolada do contexto nacional e social. Ele cita Tayama Katai e Shimazaki Tōson como precursores do gênero na literatura japonesa. No âmbito da história cultural do Japão, os críticos Kitazumi Toshio e Kikuda Shigeo mostram uma visão idêntica à de Takagi e Nakamura.

Com a publicação de Hakai em 1906, Shimazaki Toson consolida a literatura naturalista que se transformou num grande movimento literário, a principal corrente entre 1907 e 1917. Hakai é uma obra do realismo autêntico que estabeleceu um tema sobreposto (duplo), um reflexo do próprio autor que escreve sobre a tristeza dos que despertam e também uma crítica aguçada sobre as contradições da sociedade que envolvem os habitantes dos vilarejos (burakumin). Entretanto, Toson, na sua obra seguinte que é Haru, direciona-se para um estilo autoconfessional (jiko kokuhaku bungei) juntamente com Futon de Katai, abandona o interesse pela sociedade e escolhe o caminho para a literatura confessional. Tokuda Shūsei, Iwano Hōmei, Masamune Hakuchō, Mayama Seika também apresentam essa forte tendência para a autoconfissão e a visão de vida niilista com postura contemplativa não idealista/insolúvel e da tristeza da revelação da realidade, abandonam a ficção e focalizam a verdade da vida.

Shimamura Hōgetsu, Hasegawa Tenkei, Katayama Tengen e outros defenderam várias teorias com base em suas lógicas. Chikamatsu Shūkō, Kasai

\footnotetext{
${ }^{13}$ Famílias que se ocupavam do abate de animais e eram consideradas inferiores.
} 
Zenzō e outros aumentam os elementos confessionais que descrevem o desejo amoroso e a dificuldade da vida e tomam um rumo cada vez mais acentuado para o romance do eu, simbolizando o destino do Naturalismo. ${ }^{14}$

A orientação para o Romance do Eu foi reforçada pelos já mencionados escritores naturalistas Iwano Hōmei, Tokuda Shūsei e Chikamatsu Shūkō, os quais, após a publicação de Futon, seguiram a tendência confessional. A obra Tsukimono (Encosto), de Hōmei, é apresentada por Nakamura Mitsuo ${ }^{15}$ como um Romance do Eu perfeito, no sentido de ter sido escrito do princípio ao fim sob a visão subjetiva do autor. Shūsei, como um dos representantes máximos do Naturalismo, foi alvo das atenções com Arashotai (Nova Família, 1908). Passou a escrever Romance do Eu a partir de 1910, retratando a vida de sua esposa na obra Ashiato (Rastros). Mas, como já foi mencionado, para o crítico Nakamura Kabi é a obra mais representativa desse autor e também o modelo do Romance do Eu naturalista. Nessa obra, Shūsei mostra como símbolo da vida sem ideal e sem solução a história do protagonista Sasamura e seu desdobramento, um homem casado e atormentado pelo insucesso profissional como escritor que a tudo suporta passivamente e sem esperanças. Reconhecido em 1910 com Wakareta tsuma ni okuru tegami (Carta Enviada a minha Ex-esposa), Chikamatsu Shūkō dedicou-se ao Romance do Eu, escrito com uma grande dose de lirismo subjetivo - um escritor que revelou a fraqueza masculina sem a menor hesitação.

A corrente Shirakaba costuma ser citada pelos livros de história da literatura e pelos críticos literários como fonte do Romance do Eu ou como movimento que o impulsionou e o desenvolveu. Especialmente as obras do escritor Shiga Naoya, ${ }^{16}$ que foi mais descritivo e fiel a seus sentimentos e lutou contra as pressões e injustiças das quais se sentia vítima. Hirano Ken, por exemplo, em Geijutsu to Jisseikatsu (Arte e

\footnotetext{
${ }^{14}$ Kindai Bungei no Keisei (Formação da Arte Literária Moderna). In: Ichiro Ishida. Nihon Bunkashi Gairon, Capítulo 30.

${ }^{15}$ Op. cit. p. 12.

${ }^{16}$ Muito mais que um segundo foco que dá continuidade ao Romance do Eu, Shiga é visto como o autor que, principalmente com a obra Kinosaki nite (Em Kinosaki), de 1917, desenvolveu e consolidou o romance introspectivo, um desdobramento do Romance do $\mathrm{Eu}$, que será examinado nas páginas seguintes.
} 
Vida Real), de 1958, considera que o Romance do Eu só se formou quando, ao Naturalismo, foi acrescido o individualismo e o humanismo da corrente Shirakaba.

Odagiri observa que quando os escritores da corrente Shirakaba não conseguiram expandir suas idéias, desgastadas pelos embates com a realidade que os cercava, eles tenderam a expressar sua interioridade, aumentando o número de obras que passaram a narrar o estado de espírito de seus escritores por meio da observação do "eu" e das oscilações de seus sentimentos diante dos fatos particulares.

Apesar de ou de tanto se discutir sobre o Romance do Eu, sua origem acabou cercada de indefinições, cada crítico apontando uma obra como inaugural. Como já foi mencionado, na visão de Odagiri Hideo, Kasai poderia ter sido o criador do primeiro Romance do Eu se Shūkō não tivesse sido reconhecido, já em 1910, com Wakareta Tsuma ni Okuru Tegami, do qual Giwaku é uma continuação. A estréia literária de Kasai ficou sendo em 1918, com a obra Ko o Tsurete (Levando as Crianças). Nas obras desse autor, o lirismo é substituído por abnegação e desapego às coisas materiais, e essa propensão dos autores para imprimir na literatura a peculiaridade e a energia de sua individualidade, como fez esse autor, é uma característica fundamental do Romance do Eu. Kasai é um exemplo de quem viveu numa época em que o desenvolvimento das revistas e dos jornais exigia uma quantidade maior de obras produzidas em um curto espaço de tempo, e exemplo de uma escrita a respeito do sofrimento de não conseguir escrever e também sobre ele próprio narrando esse sofrimento. Em, Kindai Sakka ni Miru "Watakushi”: Tayama Katai to Tokuda Shūsei ( $O$ "Eu” nos Escritores Modernos: Tayama Katai e Tokuda Shūsei), o estudioso Enomoto ${ }^{17}$ diz que com Suikyōsha no Dokuhaku (Confissões de um Decadente), publicada em 1927, já próximo a sua morte, Kasai mostrou que a arte e a vida são inseparáveis e que havia decidido iniciar a partir da destruição.

Em Hirano Ken Sakka Ron Shū (Coletânea de Teses Sobre Autores por Hirano Ken) de 1971, a atitude de Shūkō é vista como uma exposição extrema de quem abandona o convívio em sociedade sem receio nenhum. De acordo com Hirano, essa coragem destruidora, associada ao isolamento no círculo literário, serviu como linha principal e como padrão do Romance do $\mathrm{Eu}$, gerando a confusão que 
levou o leitor a interpretar o "eu" protagonista como sendo o próprio autor. A premissa de que o "eu" é o autor era indispensável no chamado registro entre amigos do círculo literário, e o crítico a inclui entre os fatores que deram origem ao Romance do Eu e que ajudaram a criar essa forma de recepção na qual a identificação do "eu" com o autor leva à dedução de que todo o conteúdo restante é verídico.

A auto-exposição fiel presente nesse tipo de romance surgido entre 1919 e 1920 foi sustentada pela crença dos autores da Shirakaba de que a expansão do ego ligava-se à vontade da humanidade, bem como pela certeza que os escritores tinham de que suas palavras e ações atraíam o interesse dos leitores. Dessa maneira, o Romance do Eu que se baseava na depreciação da vida de seus autores e o Romance do $\mathrm{Eu}$ repleto de otimismo motivado pela consciência de que os escritores pertenciam a uma elite tornaram-se comuns e geraram sucessores nesse período, também com a ajuda da formação dos círculos literários que se isolavam da sociedade. A propósito da formação de círculos literários com tais características, e por extensão, do Romance do Eu, Hirano levanta a suspeita de que eles seriam resultado de um desvio da literatura naturalista, que passou pela perseguição aos socialistas e anarquistas em 1900 e levou centenas de pessoas à prisão, sendo 26 processadas por traição ao Imperador e 24 condenadas à morte.

Segundo Hirano, ${ }^{18}$ a profusão do Romance do Eu não significou que ele preenchera os quesitos para ser importante tendência literária, pois não chegou de fato a ser alvo das considerações dos escritores e críticos. Somente por volta de 1923, ou seja, praticamente dez anos depois da publicação de Giwaku, o Romance do Eu passa a ser visto por todo o círculo literário como uma idéia ou princípio literário, mas sem qualquer teorização a respeito, porque ainda continuava sendo uma questão secundária. Tal demora foi decorrente da falta de estrutura da crítica da época, que se limitava a pareceres baseados em impressões.

O ano de 1916 é visto por Odagiri como de transição na história da literatura moderna japonesa, pois a "literatura trabalhista" alcançou nível artístico, com a obra

\footnotetext{
${ }^{17}$ Takashi ENOMOTO, Revista Kokubungaku Kaishaku to Kanshō, v. 36, n.10, p, 50.

${ }^{18}$ Ken HIRANO, Watakushi Shōsetsu no Niritsu Haihan, p.229.
} 
Kōfu (Carvoeiro), de Miyajima Sukeo; a arte popular começou a ser discutida; e surgiram teorias sobre a extinção da literatura de entretenimento do período prémoderno. Shiga Naoya, que havia se afastado do meio literário, indo para Abiko, retomou suas atividades de escritor em 1917, adotando um estado de espírito mais sereno. Enquanto autores como Katai, mudaram o foco para a religião, a nova geração naturalista composta por autores como Hirotsu Kazuo continuou com uma visão obscura do homem, ao mesmo tempo em que se aproximava do egocentrismo e do idealismo da corrente Shirakaba. Promovendo a aproximação dessas idéias com a vida popular, esses autores convergiram para temas amorosos humanistas, sentimentais e acompanhados de crítica social. Esses movimentos ligaram-se ao desenvolvimento do povo e da classe trabalhadora e desencadearam a assim chamada literatura proletária nos anos de 1925.

As discussões sobre o Romance do Eu começaram aproximadamente nessa época, em que surgem a literatura proletária e os movimentos literários modernistas da corrente Neo-sensorialista ${ }^{19}$, com o intuito de renovar e reformular o Romance do $\mathrm{Eu}$ e o romance introspectivo, e quando aumenta a demanda dos meios de comunicação, ávidos por publicar um maior número de obras. Nakamura Murao foi um dos pioneiros nessas discussões, escrevendo Honkaku Shōsetsu to Shinkyō Shōsetsu (Romance Autêntico e Romance Introspectivo), em 1924. Ele definiu o romance introspectivo como um romance que, em vez de narrar uma vida ou uma sociedade, preocupava-se unicamente em narrar o estado de espírito do autor, e observou que essa tendência se fazia presente de modo significativo nas obras de Satō Haruo, Kasai Zenzō, Nagai Kafū, Hirotsu Kazuo, Shiga Naoya e Uno Kōji. Coloca o "romance autêntico" acima do romance introspectivo, defendendo-o como o verdadeiro caminho da arte literária, e critica o rumo tomado pelo Romance do Eu como uma frustração para o círculo literário.

Em 1925, Kume Masao contesta a teoria de Nakamura Murao com Watakushi Shōsetsu to Shinkyō Shōsetsu (Romance do Eu e Romance Introspectivo). ${ }^{20}$ Nessa obra, Kume explica que utilizou o termo shinkyō — em tradução literal, "estado de

\footnotetext{
${ }^{19}$ V. Apêndice, p. 63.

${ }^{20}$ Masao KUME, Nihon Gendai Bungaku Zenshū 57 Kikuchi Hiroshi; Kume Masao Shū, p. 406.
} 
espírito" - para expressar o estado de espírito no momento da composição da obra, buscando explicar melhor o Romance do Eu, pois, na época, o leitor confiava na veracidade dos romances como expressão do sentimento e das impressões do autor no momento da elaboração da obra, acreditando que ele expunha os fatos tal qual tinham acontecido na realidade, expressando seu próprio "eu" com sinceridade e sem disfarces. O estudioso tentou caracterizar o Romance do Eu como uma obra na qual o autor revelava-se integralmente, mas não como numa autobiografia ou numa confissão. Reconstituiria a vida do autor consciente de seu "eu" interior, sem distorções, exagero ou falta, mas não em seu estado bruto; passaria por um processo de elaboração que condensaria e filtraria esse "eu", fazendo-o renascer mediante uma contemplação sólida e desprovida de erro. Parece-nos que essa visão de Kume aproxima-se do que disse Antônio Cândido, ao traçar o percurso do romance:

Para o estudo do romance moderno é importante assinalar que as narrativas e os romances antigos e medievais se propunham como obra de pura fantasia. Por isso não havia limites à imaginação. $O$ romance propriamente dito aparece quando estabelece limites à fantasia e quando procura aproximar-se da realidade. Nos séculos XVI-XVII, quando o romance começa a abandonar a fantasia, tem uma subordinação excessiva à realidade. Assim, os romances e romancistas procuram dar a impressão de que narram histórias verídicas. [...] $O$ romance só adquire as características atuais quando admite uma terceira atitude: é uma obra de fantasia, que procura aproximar-se o mais possivel da realidade. ${ }^{21}$

$\mathrm{Na}$ prática, no entanto, acreditava-se que o Romance do $\mathrm{Eu}$ ou o romance introspectivo não eram produto de técnicas realistas e sim obras verídicas, fiéis à vida do autor.

Odagiri diz que as visões de Nakamura e de Kume possuíam em comum a ênfase na função do "eu" do autor dentro da obra e a negligência para com o conteúdo da obra e a realidade do "eu". Por isso, discutiam apenas as questões externas à obra. Vários críticos continuaram a fazer o mesmo, mudando apenas as formas de apresentação.

${ }^{21}$ Antônio CÂNDIDO, Análise Crítica do Romance, p. 3. 
Ainda por volta de 1925, pareceres favoráveis como os de Uno Kōji ${ }^{22}$ e Satō Haruo $^{23}$ surgiram ao lado de Kume Masao, ${ }^{24}$ e não favoráveis, como o de Ikuta Chōkō, ${ }^{25}$ ao lado de Nakamura Murao. ${ }^{26}$ Ao final dessa fase de prós e contras, o Romance do $\mathrm{Eu}$ tornou-se uma expressão literária conhecida na literatura moderna japonesa, e autores de diversas correntes literárias o escreveram em situações as mais variadas. Mesmo assim, o tom de reprovação da crítica continuou tanto em relação a seu valor e o que ele representava quanto a sua falta de elaboração estrutural, sua natureza alheia ao contexto social e político do país, ou ainda à alienação de seus escritores fechados nos círculos literários.

Com o avanço da assim chamada literatura proletária a partir de 1925 e sua liderança momentânea no âmbito literário, as discussões sobre o Romance do Eu desapareceram das revistas literárias durante algum tempo, mas mesmo no auge da literatura proletária Kamura Isota, Takii Kōsaku e Kajii Motojirō continuaram com suas produções. Enomoto ${ }^{27}$ expõe que Chichi o Uru Ko (Pai que Vende Filho), 1924, de autoria de Makino Shin'ichi, e Gyōku (Sofrimento), de Kamura Isota, 1928, são obras que ainda tratam do tema da família, nos moldes do Naturalismo, exemplos raros que conseguiram reconhecimento no auge da literatura proletária e se estabeleceram vencendo as novidades da mencionada corrente Neo-sensorialista e da corrente Modernista ${ }^{28}$ surgida logo em seguida.

Em 1932, época da revolta da Manchúria, o movimento que impulsionava a literatura proletária, que produziu obras expressivas como Kani Kōsen (Navio de Caranguejos, 1919), de Kobayashi Takiji, e Taiyō no Nai Machi (Cidade Sem Sol, 1929), de Tokunaga Sunao, e que contou com a atuação de escritores como Nakano Shigeharu e Miyamoto Yuriko, é extinto após receber fortes pressões

22 Kōji UNO, "Watakushi Shōsetsu" Shiken (Minha visão sobre o "Romance do Eu”), Revista Shinchō, outubro de 1925. Aqui, o estudioso mostra uma visão oposta à apresentada em 1920.

23 Haruo SATO, Shinkyō Shōsetsu to Honkaku Shōsetsu (Romance Introspectivo e Romance Autêntico), Revista Chuō Kōron de março de 1928.

${ }^{24}$ Masao KUME, Op. Cit. P.406-411, publicado pela primeira vez na revista Bungei Kōza, jan. 1925.

${ }^{25}$ Chōkō IKUTA, Nichijō Seikatsu o Henchō Suru Akukeikō (Uma tendência que superestima o cotidiano), Revista Shinchō, julho de 1924.

${ }^{26}$ Murao NAKAMURA, Honkaku Shōsetsu to Shinkyō Shōsetsu (Romance Autêntico e Romance Introspectivo), Revista Shin Shōsetsu, janeiro de 1924.

${ }^{27}$ Takashi ENOMOTO, Shōwa Bungakushi - Watakushi Shōsetsu no Isō (História da Literatura Shōwa - Posição do Romance do Eu), p. 51. 
governamentais, que culminaram com a prisão e execução de Kobayashi Takiji, um dos nomes mais expressivos dessa tendência. Em seu lugar, surgiu a chamada literatura de conversão, composta pelos antigos escritores do movimento proletário, obrigados a abandonar seus pensamentos e suas convicções políticas. Seikatsu no Tankyū (A Busca pela Vida, 1937) de Shimaki Kensaku, e Kokyū Wasureubeki (Não se Deve Esquecer a Terra Natal, 1935) de Takami Jun, são algumas das obras escritas depois que a Liga dos Escritores Proletários foi dissolvida pelo governo em fevereiro de 1934, sendo que muitos deles passaram a escrever seus sofrimentos de modo aberto por meio da literatura do Romance do Eu.

$\mathrm{O}$ recuo da literatura proletária traz de volta o vigor do Romance do Eu e do romance introspectivo, com a atuação de Tokuda Shūsei e Uno Kōji, e a retomada das discussões sobre o gênero. Incitados pela trivialização do romance, Yokomitsu Riichi escreveu Junsui Shōsetsu Ron (Teoria do Romance Puro) e Kobayashi Hideo, Watakushi Shōsetsu Ron (Teoria do Romance do Eu), em 1935. Kobayashi repensou o Romance do Eu em termos comparativos com a literatura moderna européia e mostrou que ele era conseqüência não apenas de uma natureza subjetiva do povo japonês, mas também de uma sociedade sem estruturas para criar um pensamento de tipo europeu e de escritores que não sentiam necessidade de se envolver com novas idéias. Diante disso, novamente, Kume $\mathrm{Masao}^{29}$ saiu em defesa do Romance do Eu como habilidade extra de alguém que é levado a expor seu estado de espírito.

A partir dessa época até o início da guerra com a China, em 1937, Tokunaga Sunao e Nakano Shigeharu, ex-escritores da literatura proletária, encontraram meios de focalizar as contradições sociais, escrevendo sobre suas próprias vidas cercadas de pressões sociais, em Romances do Eu ou romances introspectivos. Itō Sei, por sua vez, apresenta uma nova possibilidade para o Romance do Eu como busca da verdade por meio do realismo psicológico defendido pelo Neopsicologismo, ${ }^{30}$ e tenta executar esse método como escritor nas obras Yūki no Machi (Cidade de Monstros), de 1937, e Tokunō Gorō no Seikatsu to Iken (A Vida e a Opinião de Tokunō Gōrō),

\footnotetext{
${ }^{28} \mathrm{~V}$. Apêndice p.63-64.

${ }^{29}$ Masao KUME, Jun Bungaku Yogi Setsu (Teoria da Habilidade Extra na Literatura Pura), revista Bungei Shunjū, abril de 1935.

${ }^{30}$ V. Apêndice, p. 64.
} 
de 1941, raridades durante a guerra, de escassa produção literária. Nelas, focalizou várias questões dos conflitos entre o Japão e a China, a vida e o pensamento de um intelectual da época. Itō diz tê-lo feito com o intuito de descrever a vida de um homem contemporâneo a partir do modelo de Joyce, e não de fazer um Romance do Eu, como diz Enomoto em Watakushi Shōsetsu no Isō.

Com o aumento das pressões do militarismo durante a Segunda Guerra Mundial, os Romances do $\mathrm{Eu}$ foram produzidos e lidos como paliativos para a tristeza. Após a guerra, apesar de os autores não terem sido capazes de se desvencilhar por inteiro da limitação egocêntrica desse estilo de romance, mostraram maior maturidade, e a maioria das obras ficou na esfera do romance introspectivo com Kanbayashi Akatsuki, Dazai Osamu e Tanaka Hidemitsu, autores novos que tentaram ressaltar a pureza da autodestruição.

Em 1948, o Romance do Eu recebeu dois modelos de classificação com Shōsetsu no Hōhō (O Método do Romance), de Itō Sei: o conflituoso e o harmonioso. Os escritores que se isolaram da sociedade e viveram no e para o círculo literário foram descritos como "escravos fugitivos" que conseguiram revelar sua voz interior de forma mais autêntica e franca nesse ambiente de proteção, em que as obras literárias que buscavam o sentido da vida humana eram valorizadas. Transpor suas experiências para o papel era expor o lado mais obscuro de suas próprias vidas e também das de seus familiares ou amigos, era fazer revelações que não permitiam arrependimentos. Assim, as obras, favorecidas pela comoção que causavam no leitor, mas que ao mesmo tempo expunham seus autores à possibilidade de desgraçar a própria vida, foram classificadas pelo estudioso no "modelo conflituoso", e as obras que descreviam a vida do autor levando em consideração sua posição como seres socialis, no "modelo harmonioso". Seus autores foram denominados "gentlemen disfarçados".

Em 1950, Nakamura Mitsuo escreveu Fūzoku Shōsetsu Ron (Teoria do Romance de Costumes), no qual traça as origens e o desenvolvimento do realismo moderno nas obras dos autores japoneses, identificando o nascimento do Romance do Eu a partir de um desvio representado pela obra Futon, de Katai, que acabou servindo de modelo para muitos autores que, independentemente do pensamento ou 
da corrente literária a que pertenciam, quiseram se adequar à literatura ocidental, julgando que a fórmula mais fácil era escrever sobre si mesmos. Hidaka Shōji ${ }^{31}$ diz que Nakamura foi original por ter introduzido como fundamento do Romance do $\mathrm{Eu}$ “o pensamento de que não há coisa mais certa do que escrever sobre si mesmo, pois tratando-se de fatos reais, é impossível que sejam mentiras".

Seguindo uma linha semelhante a de Itō, Hirano Ken expôs, em 1958, na obra Geijutsu to Jisseikatsu, que o Romance do Eu e o romance introspectivo eram obras que aparentemente abordavam temas do cotidiano, mas que no fundo nenhuma delas trazia fatos cotidianos, ordinários. Ou seja, ambas apresentavam uma situação de crise ou de risco e um desejo de salvação ou de superação. No Romance do Eu, essa crise podia manifestar-se ligada à esfera familiar ou sob a forma de uma revelação da situação enfrentada pelo próprio autor, buscando sua salvação e superação na arte. No romance introspectivo, a crise já estaria superada e seria apresentada como processo de busca do equilíbrio na vida real. Nesse sentido, pode-se dizer que Hirano associou o Romance do Eu ao "modelo conflituoso", e o romance introspectivo, ao "modelo harmonioso" de Itō.

Segundo Asami, foi a partir desse desdobramento que o romance introspectivo assumiu um sentido novo, diferente do de Kume em 1925, ou seja, uma expressão para explicar o estado de espírito do autor no momento da criação da obra, tornando-se distinto do Romance do Eu, que, a partir de então, passou a designar as obras que relatavam a crise no exato momento em que ela era enfrentada, sem uma certeza de resolução - uma literatura produzida por escritores que abriam mão do convívio em sociedade e buscavam a salvação na arte, cujo exemplo era a linhagem que ia de Chikamatsu Shūkō a Dazai Osamu, passando por Kamura Isota. O romance introspectivo, ao contrário, relata a superação da crise, e por conseguinte busca a salvação na vida real, o que para Asami teve origem na literatura da corrente Shirakaba idealista e seguiu a linhagem que foi de Shiga Naoya até Ozaki Kazuo, passando por Takii Kōsaku.

\footnotetext{
${ }^{31}$ Shōji HIDAKA, "Kindai Shōsetsu" Riron no Shosō (Aspectos Teóricos do "Romance Moderno"), in: Kōza Shōwa Bungaku Shi 3 Yokuatsu to Kaihō-Senchū kara Sengo e, p. 171.
} 
Como demonstrou Asami, portanto, o Romance do Eu é uma expressão genérica que abrange o "modelo conflituoso" - o Romance do Eu no sentido restrito — e o "modelo harmonioso" - o romance introspectivo.

Tanto a concepção de Itō Sei quanto a de Hirano são extremamente ligadas à sociedade, à relação ou à postura que o autor tem ou assume para com ela; nesse sentido, podemos dizer que eles focalizaram a relação entre obra e vida no Romance do Eu.

A relação íntima que a obra apresenta com a vida na literatura japonesa foi observada por Odagiri como proporcionada por um terreno propício, o mesmo que levou à formação do Romance do Eu: a poesia lírica dos poemas japoneses como o $t \operatorname{tanka}^{32}$ e o haiku $u^{33}$ e as obras em prosa que buscaram efeitos líricos. Segundo ele, a literatura japonesa possui uma tendência marcante a se afastar da realidade social e objetiva, e que os japoneses buscam a satisfação por meio do lirismo em torno de si mesmos, tocados pelas experiências pessoais e pelos fatos que os cercam. Cita como exemplo o lirismo das expressões utilizadas por Murasaki Shikibu na cena de dor do Imperador pela morte de Kiritsubo, ${ }^{34}$ o que tornou secundária a triste história de amor entre o casal, e afirma que a natureza lírica dominou a literatura japonesa em todas as épocas muito mais do que se imagina, com obras que privilegiaram o prazer das oscilações do estado de espírito e da resignação serena, evidenciando essa forte tendência para o "eu".

Devemos lembrar que os diários literários japoneses e os ensaios, que ocuparam parte significativa do período clássico, foram manifestações literárias que procuraram retratar as experiências do cotidiano do autor para representar a realidade vivida, seja pela descrição de acontecimentos relevantes ou marcados por algum evento ou, ainda, fatos considerados comuns, mas que apelam para a sensibilidade dos que compreendem os mesmos sentimentos e vivências e compartilham deles. $\mathrm{O}$ diário surgiu no século $\mathrm{X}$ e firmou-se como literatura que privilegiava os fatos

\footnotetext{
${ }^{32}$ Poema composto por 31 sílabas dispostas em versos de 5, 7, 5, 7 e 7 sílabas.

${ }^{33}$ Poema com 17 sílabas dispostas em versos de 5, 7 e 5 sílabas.

${ }^{34}$ Personagem feminina de Genji Monogatari (Narrativas de Genji), que se torna a preferida do Imperador e atrai para si o ciúme e o ódio de suas outras esposas, o que a leva à morte. V. Apêndice, p. 31,32 e 35 .
} 
verídicos, como demonstrou a autora de Kagerō Nikki (Diário do Pirilampo), ${ }^{35}$ que, se dizendo farta das obras do mundo do faz-de-conta, resolveu registrar sua vida na esperança de servir de referência ou exemplo para a posteridade. Precedido em alguns anos pelo ensaio, seu gênero contemporâneo, compõe com este parte da famosa literatura feminina palaciana que floresceu no Japão entre os séculos XI e XIII. Passado esse momento próspero, o diário tornou-se um gênero menos expressivo nos séculos seguintes, mas manteve-se como um hábito muito comum não apenas dos escritores, mas também dos japoneses de um modo geral.

O ensaio recebeu novo enfoque dentro da Literatura Budista dos Retirados, nos séculos XIII e XIV, e deixou Hōjōki (Registro da Cabana de Nove Metros Quadrados), escrito em 1212 por Kamono Chōmei (1155 ou 1153-1216), e Tsurezuregusa (Anotações no Ócio), de 1331, de autoria de Urabe Kenkō ( $₫ 1283$ 1350). Essas duas obras expressivas compõem a Literatura dos Retirados (Inja Bungaku) ou a Literatura da Cabana (Sōan Bungaku) da Idade Média japonesa. Ambas discorrem sobre a efemeridade, mas a primeira lamenta a inconstância deste mundo, ao passo que a segunda valoriza a inconstância e a diversidade. Nakamura ${ }^{36}$ acredita que os escritores intuíram que só garantiriam sua individualidade fugindo de uma realidade dominada pela moral social, e que a "forma ensaio" lhes serviu para expressar sua voz interior. O ensaio é um modelo adequado para garantir a integridade dos escritores se pensados como "escravos fugitivos" ou os "gentlemen disfarçados" de Itō Sei no contexto social em que foram escritos.

Pela natureza do conteúdo dos ensaios e dos diários, constatamos que constituem registros que partem do ponto de vista subjetivo do autor; os primeiros abordam temas mais gerais, como a efemeridade da vida, ao passo que os outros focalizam temas ligados à vivência cotidiana do autor ou da autora, como é mais comum nos diários do período clássico, abordando suas relações pessoais e suas emoções de maneira bastante realista e com uma dose de lirismo reforçada pelos poemas que muitas vezes quase exercem a função de "diálogos" na comunicação

\footnotetext{
${ }^{35}$ Obra composta por três tomos e que retrata a vida de alegrias e tristezas da autora, conhecida apenas como mãe de Fujiwara no Michitsuna. V. Apêndice, p. 19-20.

${ }^{36}$ Mitsuo NAKAMURA, Fūzoku Shōsetsu Ron - Kindai Riarizumu Hihan (Teoria do Romance de Costumes: Crítica do Realismo Moderno), p. 67.
} 
entre as personagens. Por essa ligação mais direta do diário com o lado emocional de seus autores, sentimos que eles têm uma proximidade maior com o Romance do Eu, diferentemente do que ocorre com o ensaio, de natureza mais filosófica.

Ainda no entender de Enomoto, a tradição dos diários e dos ensaios também serviu para direcionar o Romance do Eu para um mundo de auto-isolamento, no qual os intelectuais não tinham um lugar público para atuar em meio à pressão do governo; para eles, a autoconfissão não significava um confronto com o sistema de valores públicos e sociais desse mundo, e sua consciência crítica buscou um caminho de salvação oriental por trás da bela expressão "espírito de busca". O Romance do Eu produzido durante a guerra foi visto pelo estudioso como resultado da fuga dos intelectuais, ou como deformação de seus sofrimentos, que não conseguiram expressão na sociedade, sendo sua peculiaridade vista como demonstração de uma técnica de alto nível e com grande força de penetração espiritual e mental.

Odagiri viu o afastamento dos literatos, alheio à vontade deles, como característica da tradição literária do Japão, um país constantemente dominado pelo autoritarismo. Diante dessa situação de rígido cerceamento ideológico e psicológico, o desejo de liberdade teve de ser expresso esteticamente numa forma que garantisse a autopreservação e num ambiente isolado da sociedade. Como é do conhecimento geral, a liberdade de pensamento e expressão no país só foi adquirida após o final da Segunda Guerra Mundial, e durante o período moderno o "eu" do autor não tinha forças para tratar das questões humanas ou sociais, muito menos para derrubar a ordem imposta, de modo que o autor anulava a si mesmo como ser social.

Em termos estruturais, o Romance do Eu apresenta o foco narrativo tanto na primeira quanto na terceira pessoa do singular, mas a fórmula "protagonista = autor", que garante a veracidade da obra, gera alguns contrapontos. Não é estranho que apresente um narrador homodiegético, como é o caso do narrador-protagonista, pois temos um autor-narrador falando sobre si mesmo, como numa autobiografia, num romance epistolar ou num livro de memórias. No entanto, o foco narrativo do Romance do Eu na terceira pessoa é inusitado. O protagonista tem um nome que não é o do autor, mas a identidade deste com a do protagonista continua mantida pela fórmula dessa forma de romance, por fatores externos à estruturação da obra que, 
nesse caso, não leva o narrador em consideração. Em termos de classificação feita pela narratologia, o Romance do Eu teria tanto o narrador homodiegético quanto o heterodiegético, pois o foco das considerações japonesas está nos elementos extratextuais, e a identidade entre o autor e protagonista serve sobretudo para garantir a veracidade da obra. Por isso, no caso do Romance do $\mathrm{Eu}$, a diferença entre o narrador homodiegético e o heterodiegético foi irrelevante nos estudos feitos pelos críticos japoneses.

Sabemos que, como diz Wellek e Warren:

Mesmo quando uma obra de arte contém elementos que possam com segurança ser identificados como autobiográficos, tais elementos estarão de tal modo reelaborados e transformados na obra que perdem o seu significado especificamente pessoal e s tornam apenas material humano concreto, partes integrantes da obra. [...]

Pode demonstrar-se que é falsa a própria concepção de que a arte é autoexpressão pura e simples, a transcrição de sentimentos e experiências pessoais. Até quanto entre a obra de arte e a vida de um autor exista uma estreita relação, tal não pode ser interpretado como querendo dizer que a obra de arte é uma mera cópia da vida. O método biográfico esquece-se de que uma obra de arte não é apenas a incorporação da experiência: é sempre a mais recente obra de arte numa série de obras de arte; é um drama, um romance ou poema, determinadoe só na medida em que o pode ser -, mas, ainda assim, determinado pela tradição e pela convenção literárias. ${ }^{37}$

Mesmo sendo uma obra que quer garantir sua veracidade e autenticidade acreditando na sinceridade do autor para relatar suas experiências pessoais, seja na forma de aproveitamento de pequenos episódios ou de sua vida como um todo como obra literária, ela é ficção nos termos definidos por Wellek e Warren quando discorrem sobre a natureza da literatura ${ }^{38}$. Por isso, entendemos o Romance do Eu como representação da vida do autor e, portanto, uma obra de fícção.

Nesse aspecto, devemos lembrar Hayden White, quando diz que até a História que pretende ser verdade é ficção. Diz o pesquisador:

\footnotetext{
${ }^{37}$ René Welle \&Austin Warren, Teoria da Literatura, p. 95.

${ }^{38}$ Idem, p. 25-34.
} 
Trata-se, obviamente, de uma ficção do historiador, a suposição de que os vários estados de coisas que ele constitui na forma de começo, meio e fim de um curso do desenvolvimento sejam todos "verdadeiros" ou "reais" e que ele simplesmente registrou "o que aconteceu" na transição da fase inaugural para a fase final. Porém tanto o estado inicial de coisas quanto o final são inevitavelmente construções poéticas e, como tais, dependentes da modalidade da linguagem figurativa utilizada para lhes dar o aspecto de coerência. Isto implica que toda narrativa não é simplesmente um registro "do que aconteceu" na transição de um estado de coisas para outro, mas uma redescrição progressiva de conjuntos de eventos de maneira a desmantelar uma estrutura codificada num modo verbal no começo, a fim de justificar uma recodificação dele num outro modo no final. Nisto consiste o "ponto médio" de todas as narrativas. ${ }^{39}$

À luz das palavras de White, consideramos uma vez mais que o Romance do Eu é um trabalho semelhante ao do historiador que tenta reconstituir a "verdade", mas acaba criando uma ficção. Como diz o estudioso que defende o texto histórico como artefato literário:

a narrativa histórica não reproduz os eventos que descreve; ela nos diz a direção em que devemos pensar acerca dos acontecimentos e carrega o nosso pensamento sobre os eventos de valências emocionais diferentes.

Isso porque 0

modo como uma determinada situação histórica deve ser configurada depende da sutileza com que o historiador harmoniza a estrutura especifica de enredo com o conjunto de acontecimentos históricos aos quais deseja conferir um sentido particular. Trata-se essencialmente de uma operação literária, vale dizer, criadora de ficção.

O norte-americano Donald Keene, um dos primeiros e renomados estudiosos estrangeiros da literatura japonesa, dedica um de seus volumes sobre a história da literatura japonesa ao Romance do Eu dentro do período moderno e contemporâneo.

Ao apresentar o Romance do Eu nessa obra, ele questiona a falta de definição a seu respeito, mas acaba dando sua própria definição, afirmando que, de um modo geral, ele consiste em uma narração do autor sobre o que ocorreu em sua vida, mas

\footnotetext{
${ }^{39}$ Hayden WHITE, Trópicos do Discurso: Ensaios sobre a Crítica da Cultura, p. 115.
} 
expondo os fatos nua e cruamente sob a forma de confissão. Acredita que seus escritores sentiam prazer nesse ato de escrever sobre aspectos que jamais revelariam em situações normais. Para ele, o que distingue outras obras autobiográficas do Romance do $\mathrm{Eu}$ é que estas se originam do Naturalismo japonês, e apresenta outra corrente $^{40}$ ligada intimamente com a experiência do autor, que consiste em buscar o sentido profundo nos atos mais singelos e nas pequenas nuanças das palavras ${ }^{41}$.

Assim, Keene insere o Romance do Eu como um fenômeno com data e local de nascimento e diz que obras como Maihime (A Dançarina, 1890), de Mori Ōgai, escrito em primeira pessoa, não fazem parte desse "gênero". Na realidade, ao explicar o Romance do Eu, o estudioso apresenta seus autores, na medida em que define serem esses os que escreveram não apenas uma obra autobiográfica, como fez Tanizaki, mas várias, e que não se satisfazendo com uma ou duas confissões debruçaram-se numa repetida auto-análise. Tais revelações da intimidade dos autores, narradas sem algo que se podia considerar como enredo, obtiveram, por vezes, efeitos poéticos, e é isso que, em seu entender, distingue claramente a literatura naturalista prosaística do Romance do Eu, que se limita a bater na mesma tecla, de uma outra corrente do Romance do $\mathrm{Eu}$, desenvolvida dentro dos círculos literários, os chamados romances de registros entre amigos, e os romances com nomes reais escritos a partir do pressuposto de que o leitor sabe quem são as personagens do romance e por isso teria interesse em sua leitura.

Para Keene, Futon é visto como Romance do Eu ou como seu precursor porque foi escrito segundo o modelo de Einsame Menschen, de Hauptmann, e por isso tem um ar de algo fabricado; ${ }^{42}$ também não é uma ou algumas obras confessionais que fazem um autor romancista do Eu, pois, segundo ele, a confissão é uma característica comum na literatura moderna japonesa.

\footnotetext{
${ }^{40}$ Keene não menciona qual, mas dá a entender que seja o romance introspectivo (shinkyō shōsetsu).

${ }^{41}$ Donald KEENE, Nihon Bungaku no Rekishi 14 (História da Literatura Japonesa 14). v. 5. p. 13-16.

${ }^{42}$ Nakamura Mitsuo, como já foi visto, também faz uma análise de Acolchoado como modelo dessa obra do escritor alemão.
} 
Ao falar sobre o surgimento da expressão, Keene salienta que "a invenção de um novo termo não garante o surgimento de uma nova forma" ${ }^{, 43}$ - mas seu comentário a esse respeito não chega a ser desenvolvido.

Keene diz que Hirano considera Giwaku, de Chikamatsu Shūkō, a obra inaugural do romance japonês, bem como que Katai e Tōson tentaram manter um distanciamento entre vida e obra, pois não conseguiam ficar indiferentes aos olhos da sociedade, ao contrário de Shūkō, que não deu a menor importância ao julgamento e à opinião alheios. Por isso, na opinião de Keene, Giwaku define a característica do típico Romance do $\mathrm{Eu}$, com sua confissão fria e indiferente, "sem vergonha" de se expor. Já no caso dos escritores do romance introspectivo, eles descobriram o sentido profundo e a beleza das coisas cotidianas, e Keene sobre isso comenta, dizendo que o crítico japonês Hirano elevou a vivência comum descrita por eles à categoria de sabedoria oriental, segundo a tradição ensaística. Continuando seus comentários sobre os estudiosos japoneses, salienta que Kume considerou o ato de escrever romances como algo que proporciona paz e tranqüilidade e que a leitura deles implica uma confiança integral, uma certeza de que o conteúdo descrito é verdadeiro, e também que Kobayashi acreditou na não-internalização da ideologia ocidental por parte dos escritores, que apenas colheram impressões e idéias que só puderam existir na técnica. Por isso, Keene afirma ser esse o motivo pelo qual o Romance do Eu convergiu para o romance introspectivo. As confissões ou as narrativas de experiências sobre a vida foram aprimoradas em direção à purificação do "eu".

Kasai e Kamura são citados como exemplos de autores que seguiram ao extremo a linha do Naturalismo, resultando na descrição de escritores covardes, autodestrutivos, incapazes de escrever, e que aproveitam a vida decadente como material para suas obras. Em sua visão, o escritor Uno Kōji, como os anteriores, conseguiu criar sua individualidade sacrificando sua vida em sociedade.

Pode-se dizer que, de um modo geral, Keene aceita a visão japonesa de que o Romance do Eu constitui a literatura da destruição, e o Romance Introspectivo, a literatura da salvação; além disso, que essas obras geralmente são curtas para não

\footnotetext{
${ }^{43}$ Donald KEENE, Nihon Bungaku no Rekishi 14 (História da Literatura Japonesa 14). v. 5, p. 16.
} 
descondensar a experiência e que tanto uma quanto a outra requerem o interesse do leitor pelo autor.

Para a estudiosa alemã Irmela Hijiya-Kirschnereit, o uso da expressão não diz respeito apenas ao uso da primeira pessoa, no qual o narrador-personagem diria watashi ou watakushi, e não shi, em função das duas leituras variadas para uma única grafia, mas ao conteúdo (enredo) dessa narrativa - que gira em torno da vida do "eu" como personagem/narrador/autor - e também à própria história dos termos que se deu no mesmo fenômeno literário (gênero), como o "Eu sou o 'romance"”. Pela explicação de Hijiya-Kirschnereit, normalmente tem-se nesse gênero a narração de uma experiência real ou uma história baseada em fatos reais que retratam a vida do protagonista, independentemente de serem narradas em primeira ou terceira pessoa.

Hijiya-Kirschnereit enfatiza que Katai não adotou o Naturalismo europeu e que a literatura européia também não "tingiu" a literatura japonesa, mas que esta absorveu a aproximação com a realidade, a veracidade, e a descrição psicológica. A diferença cultural gerou uma distorção, um engano na interpretação do que era o Naturalismo, e Katai desenvolveu suas obras em torno das concepções de natureza e objetividade. Em seus livros ele cita Darwin e os positivistas Taine e Comte, que influenciaram o método de observação científica do Naturalismo, idéias que estiveram presentes no Japão desde 1890. Mesmo assim, a estudiosa afirma que, nas obras dos escritores naturalistas, não é possível observar o interesse por uma descrição "analítica $=$ científica" de fatores deterministas como a hereditariedade, o meio e as condições históricas; o natural aparece como um automatismo misterioso em suas obras, que ficam em torno da expressão Grande Natureza, e o conceito de natureza racionalista, originário do Naturalismo, acabou desaparecendo nessa compreensão tradicional de natureza ou em meio ao misticismo, ao anti-racionalismo e à predestinação.

A idéia de objetividade também é interpretada de modo distorcido, segundo Hijiya-Kirshnereit. Na estética naturalista, o que se exigiu, segundo a base da ciência naturalista como ciência física, foi a apreensão correta da realidade que devia ser retratada. Mas esse ponto de vista científico não significou nada no caso de Katai. Para a estudiosa, a "narração nua e crua" exigida por ele dizia muito mais respeito à 
idéia de que "tudo deve ser explícito, verdadeiro e natural", e a objetividade passou a ser vista como sinônimo de "coragem, ousadia", "sem receio de ocultar nada", de "modo direto"; em resumo, uma auto-revelação, e foi isso que concretizou a forma literária na obra Futon.

Hijiya-Kirschnereit entende que essa leitura modificada dos conceitos do Naturalismo teria sido feita inconscientemente por Katai, pois ele tinha a convicção de que estava adotando um modelo da literatura européia (por isso criou-se esse fenômeno curioso que era o de seguir o modelo europeu), mas, que na realidade, refletiu, no máximo, um estímulo para que se retornasse de modo despercebido para os elementos tradicionais da literatura e história do próprio Japão. E a autora defende que esse diagrama de recepção aconteceu com o Naturalismo japonês como um todo, e não apenas com Katai. Os jovens aspirantes a escritores debruçaram-se sobre os romances de auto-revelação que surgiram como uma novidade, pois eram um modelo fácil de ser seguido. Hijiya-Kirschnereit cita Yoshida Seiichi ${ }^{44}$ para comentar que Futon foi uma inédita no sentido de obra autobiográfica, comovendo as pessoas ao revelar sinceramente toda a intimidade, pois ninguém, antes, tivera a coragem de expor o seu lado obscuro de modo tão aberto. É desse modo que, segundo a estudiosa, durante alguns anos, o mercado literário ficou repleto de obras de cunho autobiográfico e de romances confessionais.

A estudiosa diz ainda que há uma concordância entre os estudiosos japoneses sobre a definição do Romance do Eu, pois vê os textos críticos japoneses sobre o tema como tentativas de caracterizá-lo de um ponto de vista geral e trazem apenas informações parciais em meio a uma compreensão tácita. Ela comenta que o princípio do Romance do Eu é constituído pelo reconhecimento de algumas características inerentes a ele, mas que não existe uma reflexão sobre a interdependência delas. Sua definição é formada simplesmente por uma somatória dessas características, conferindo-lhe um espaço dentro da prosa literária. Isso significa que há uma indefinição quanto a uma obra ficar fora ou não da classificação do gênero caso lhe falte uma ou mais características ou que tipo de característica. Essa aporia, segundo Hijiya-Kirschnereit, vai sendo reproduzida na forma de 
diferentes expressões, como escritores do Romance do Eu, romancistas do $\mathrm{Eu}$ e Romance do Eu e obras ao estilo do Romance do Eu.

Ao levantar o que, no entendimento japonês, caracteriza o Romance do $\mathrm{Eu}$, Hijiya-Kirschnereit verificou que não ocorreram mudanças no pensamento a seu respeito durante dezenas de anos, e ainda hoje a visão formada nos anos 1920 continua a ser o apoio para seu estudo. Segundo ela, os parâmetros mais importantes para distinguir um Romance do Eu são: "ficção $\times$ realidade", "narração em primeira pessoa $\times$ terceira pessoa", natureza autobiográfica, subjetividade e proximidade com a poesia.

Na questão "ficção $\times$ realidade", Hijiya-Kirschnereit inseriu o Romance do Eu na categoria da realidade; mas, por outro lado, diz que é muito ampla a esfera de possibilidades de interpretação sobre o que entra na categoria do termo artístico literário "real" (veracidade/verídico). Toda a ficcionalidade é eliminada limitando a matéria aos "fatos" que dizem respeito à "experiência vivida pelo autor", pois a isso liga-se a forte exigência de "escrever apenas a verdade".

A compreensão sobre o que é o "real" já apresenta uma divisão tripartite. A primeira delas diz respeito ao caso em que os acontecimentos literários e os acontecimentos relacionados ao universo de vida coincidem um a um. Nesses casos, ainda há pessoas que admitem várias lacunas nos fatos. A segunda delas é a que considera a realidade como um estado psicológico da personagem principal como realidade interior. Quando isso é objeto da obra, a fidelidade à realidade acaba sendo fator secundário, pois o acontecimento passa a ter uma função simbólica. A terceira não está na relação da obra com o autor, mas em como a obra atua no leitor. Outro aspecto levantado é que o romance possui "realidade" quando a obra é vista como "natural", "não fabricada". Ela diz que o maior representante dessa visão é o grande romancista do $\mathrm{Eu}$, Shiga Naoya, que elogia uma obra que não parece ser arranjada e rejeita outra que diz ser "fabricada".

Por fim, Hijiya-Kirschnereit diz que, diante de tantas interpretações, até a tentativa de definir o padrão de "realidade" a partir da distinção com seu par oposto, que é a ficção, acaba frustrada.

${ }^{44}$ Seiichi, YOSHIDA, Kindai Nihon Bungaku Jiten, p. 60. 
Como pôde ser visto até aqui, o Naturalismo japonês tomou um rumo distinto do Naturalismo europeu e não se baseou no espírito científico. Mesmo partindo dele, desenvolveu características próprias, valorizando os fatos, a verdade e a sinceridade. Para tanto, adotou o método realista de representação, apresentou a não-solução, o não-idealismo, voltando-se para a descrição dos instintos sexuais e da realidade dos fatos, gerando obras centralizadas no relato das experiências pessoais dos autores.

Fundindo-se e confundindo-se com o Naturalismo em suas origens e processos de desenvolvimento, o Romance do Eu ocupou uma posição significativa no cenário da literatura moderna japonesa e passou a ser discutido pelos estudiosos e críticos literários, muitas vezes em tom de frustração, em razão de suas características contrárias ao rumo que eles desejaram para a prosa literária japonesa, isto é, seguiam o modelo da literatura ocidental, considerada artística em função de seu alto nível de elaboração e construção e de engajamento social. Com o passar do tempo, contudo, tais insatisfações tornaram-se aspectos secundários diante de seu reconhecimento como forma literária peculiar ao Japão, que resultou de uma adequação ao contexto social e político e à própria tradição literária japonesa.

Assim, os estudos japoneses em torno do Romance do Eu classificam as obras quanto a sua natureza e apresentam ou focalizam questões genéricas abordando suas influências, sua relação com a realidade e a vida do autor. Tais fatores são primordiais nesse romance, mas são avaliações e julgamentos também genéricos, pouco palpáveis, que não auxiliam o leitor a elucidar os aspectos formais desse gênero para que se possam identificar e classificar as obras como romances do eu sem se ater a informações extratextuais.

Donald Keene apresentou uma definição bem geral do Romance do Eu e do romance introspectivo com base nas afirmações dos estudiosos japoneses e focalizou mais os romancistas do $\mathrm{Eu}$ do que as obras em si. Hijiya-Kirschnereit, por sua vez, tentou encontrar características comuns entre as obras, mas no final expôs uma visão genérica de que os romances do $\mathrm{Eu}$ constituem um ritual de auto-revelação, conforme o título de seu livro.

Situar o Romance do Eu e as discussões em torno dele desde seu surgimento não é tarefa fácil, de modo que este capítulo procurou apresentar a visão de 
estudiosos japoneses e estrangeiros sobre o tema, por meio de informações introdutórias e necessárias.

Um dos grandes problemas encontrados no estudo do Romance do $\mathrm{Eu}$ consiste na confusão existente entre ele e o romance introspectivo, ambos vistos como tendências literárias que deveriam ter se limitado a um período, ou seja, ao Naturalismo japonês que lhes dera origem, e no incômodo que o Romance do Eu tem causado ao longo do tempo, tendo em vista sua presença persistente. Outra questão diz respeito ao interesse pelo conteúdo verídico oferecido pelo Romance do Eu e não pela verossimilhança interna que manteve sua estrutura praticamente indefinida e muito dependente das informações sobre a vida e o pensamento do autor dadas por ele mesmo ou pelas considerações dos críticos japoneses. Nosso interesse centrou-se na questão da verossimilhança interna do Romance do Eu, que será abordada no capítulo seguinte, em que faremos o estudo de várias obras de autores e períodos diversos para, mediante análise, tentar propor uma tipologia do Romance do Eu que dê subsídios para identificar ou reconhecer a obra como pertencente a esse gênero. 


\section{CAPÍTULO II}

\section{TIPOLOGIA DO ROMANCE DO EU}

Como foi visto no capítulo anterior, os teóricos japoneses começaram a discutir o Romance do Eu por volta de 1920, e apontaram como berço o Naturalismo japonês, que teve início com a introdução das novas idéias ocidentais em virtude da abertura do país no final do século XIX. Houve época, inclusive, em que se questionou a validade literária do Romance do Eu em virtude do surgimento de muitas obras que se julgavam escritas sem qualquer elaboração e nas quais o autor simplesmente relatava sua vivência em um ou mais episódios e que, por influência do Naturalismo europeu, apresentavam uma tendência para os relatos de aspectos "negros" da vida dos escritores.

Assim como os romances sociais, fantásticos e políticos, o Romance do Eu é definido pela natureza de seu tema (enredo), que é basicamente autobiográfica, memorialista, e, em alguns casos, epistolares. Pode-se dizer que é um romance baseado em fatos verídicos, reais, colhidos na vida privada do autor.

O caráter ficcional do Romance do $\mathrm{Eu}$, contudo, não é questionado neste trabalho; muito pelo contrário, é aceito. Objetiva-se, no entanto, descobrir qual é ou quais são as peculiaridades desse gênero japonês, pois os estudiosos japoneses costumam usá-lo como referência para definir outras obras, classificando-as como pertencentes ou não a esse tipo ou aproximando-as dele.

Para tanto, escolhemos um conjunto de obras com base na produção e nos escritores apontados pelos críticos e estudiosos da literatura japonesa, ou seja, a partir do cruzamento de dados obtidos por meio da lista de obras elaborada por Nakamura Mitsuo, das obras dos escritores do Romance do Eu apontados por Hirano Ken e das obras mais mencionadas por historiógrafos literários como Takagi Ichinosuke, Yoshida Seiichi, Okuno Takeo e Takahashi Hideo. Levamos em conta, ainda, as obras relevantes pelo aspecto histórico do surgimento e desenvolvimento desse gênero, conforme visto no primeiro capítulo, e os autores e as obras 
comumente mencionados nos dicionários de literatura e nos livros de história da literatura japonesa.

Assim, neste capítulo, partir-se-á do estudo das primeiras obras consideradas como Romance do Eu, em 1906, até a época em que sua produção diminui em razão do crescimento da chamada literatura proletária ligada aos movimentos trabalhistas e socialistas, por volta de 1927; em seguida, as obras que surgiram por volta da década de 1930, após o declínio desses movimentos, até os primeiros anos do pós-Segunda Guerra Mundial.

\section{Narrador e protagonistas}

Os protagonistas do Romance do eu vivem casos de amor, questões familiares, problemas financeiros, dificuldade de produzir novas obras literárias e questões ligadas à saúde são os enredos mais comuns dessas obras, que abordam a vida cotidiana do ser humano.

A insegurança e o temor em relação ao desconhecido e ao inevitável cercam a vida das personagens, sobretudo a do protagonista. O ponto central de todas essas questões é a angústia, a incapacidade ou a impossibilidade de vencer os reveses e os percalços diante das quais só lhe resta a resignação - aceitar o que a vida lhe impõe, incapaz de qualquer reação. Trata-se de um abatimento, uma prostração que tende a manter o sofrimento ou aumentá-lo, mas jamais reduzi-lo e amenizá-lo, e muito menos ultrapassá-lo. A única alternativa é suportar sem nunca enfrentar a situação, reagir para vencer e obter o sucesso ou superar-se e sair o vencedor. A presença de uma visão pessimista em relação à vida é mais forte que o momento de prazer que o protagonista poderia sentir.

Quando narrado na terceira pessoa do singular, o protagonista pode ter um nome e sobrenome ou ser identificado apenas como kare - "ele". Um caso interessante é a narração com foco alternado entre otto - "o esposo" - e tsuma - "a esposa" -, embora com ênfase maior no primeiro, para o casal que protagoniza Ie no Naka (Dentro de Casa, 1959) de Shimao Toshio, obra que ficou fora de nossa delimitação cronológica. Obviamente, o uso da terceira pessoa cria um 
distanciamento e uma neutralidade maior do que o uso da primeira pessoa, e a atribuição de nome e sobrenome às personagens reflete a intenção do autor de aproveitar esse ato, realizado por todo pai ao dar o nome a um filho, na construção da personagem, ou seja, que contenha parte da natureza ou do destino que se pretende dar a sua criação. Nesse aspecto, o uso do kare dispensa até certo ponto essa possibilidade e, de modo geral, a caracterização dos protagonistas identificados como kare, ao contrário do que se poderia esperar, são relativamente menos detalhadas.

Nas obras em primeira pessoa, o "eu" narrador ou o narrador-protagonista usa watakushi, ${ }^{1}$ jibun $^{2}$ ou boku $^{3}$ - algumas variantes possíveis para a primeira pessoa do singular em japonês equivalentes ao pronome sujeito "eu". Como os protagonistas das obras em questão são todos do sexo masculino, a diferenciação de gênero no uso desses pronomes sujeitos não vem ao caso, e sim o resultado da opção por um deles, que implica uma sensação de proximidade maior com o uso do boku; de distanciamento e modéstia, com watakushi; e de isolamento e auto-confiança, com o jibun. No caso de Otoko to Kyūkanchō (O Homem e o Pintassilgo, 1963) vez ou outra o narrador protagonista utiliza também a terceira pessoa do plural, envolvendo seus dois companheiros num ambiente de cumplicidade, mas essa obra foi uma exceção entre as estudadas.

De uma maneira ou de outra, o protagonista é passivo, fica à deriva dos acontecimentos. Diante das pessoas, é o observador, o ouvinte, o que acata a vontade e segue alguém. Quando age, é por estímulo externo. Tudo vai acontecendo em sua vida. Não é ele que faz acontecer. Falta-lhe iniciativa diante dos fatos e dos outros quando se trata de algo do cotidiano ou do nível da realização humana, e fica à mercê do tempo quando o assunto depende das circunstâncias e do destino regido pelo que está fora da alçada humana.

Em Futon (Acolchoado, 1906), nem a avidez pelo novo amor acalentado por Takenaka Tokio faz que ele tome a iniciativa de abordar a discípula Yoshiko. É ela quem lhe manda a carta como aspirante à carreira literária, é ela quem insiste em ser

\footnotetext{
${ }^{1}$ Forma de modéstia do "eu" masculino ou feminino que imprime maior formalidade.

2 Equivale à forma polida watashi, em relação a watakushi, e significa "eu mesmo", "eu próprio", também na forma polida, usada pelo sexo masculino ou feminino.

${ }^{3}$ É a forma comum de watashi, com a diferença de ser usada apenas pelo sexo masculino.
} 
aceita por ele. Quando ela sai do interior para morar em sua casa, Tokio se encanta, mas não age, e desperdiça duas chances de manifestar seu sentimento por ela. Mesmo com a insinuação do interesse de Yoshiko, ele é incapaz de tomar uma atitude. Quer, mas não vai atrás. E ele é obrigado a se resignar quando a moça acaba arrumando um namorado, e a faz voltar para a guarda de seus pais. Fica o arrependimento. Só lhe resta cheirar o acolchoado que fora dela e afogar suas mágoas enrolado no quimono que ela usava para dormir.

O protagonista é uma personagem dividida entre o querer e o poder, o ser e o parecer. É um escritor de ficção que ainda não escreveu a grande obra de sua vida e trabalha para uma editora produzindo livros de geografia. É homem, mestre, marido e pai insatisfeito. Em nome de satisfazer seus anseios por uma nova paixão ou seus desejos sexuais, é capaz de manifestar sentimentos cruéis, como imaginar que a esposa morra no parto de seu terceiro filho, ainda em gestação. Premido pela moral no âmbito profissional e familiar, ele oculta a atração pela jovem e consegue manter as aparências perante a esposa quando ela se mostra incomodada com a presença da moça, defendendo-a como modelo das mulheres modernas, mas quando fica sabendo que ela já se entregara ao namorado tortura-se por não ter aproveitado as chances que teve de ter Yoshiko em seus braços. No entanto, não assume o interesse amoroso e sexual pela discípula e camufla o desespero de tê-la perdido para o jovem Tanaka Hideo por causa da bebedeira que toma, preocupado que está com o futuro de sua discípula.

Como diz seu próprio nome, Tokio (toki que significa "hora", "momento", “tempo", e $o$, "homem"), ele é um homem do momento, do instante, muda como o tempo e permanece dentro do bambu, como revela o sobrenome Takenaka (take que significa "bambu" e naka, "dentro", "interior"), incapaz de romper a casca e assumir seus desejos. Por isso, é um indivíduo obrigado a viver de modo dissimulado, mergulhado em seu egoísmo masculino e cruel. Em nenhum momento da obra é revelado qualquer sentimento seu de carinho pela família, esposa, filhos ou cunhada, nem de respeito em relação aos pais de Yoshiko. Sua preocupação é apenas consigo mesmo, com seus desejos e sua reputação perante a sociedade. É obstinada a maneira como ele quer afastá-la de Hideo, chega a faltar ao trabalho para fazer a mudança 
dela e prefere entregá-la aos pais a deixar que fique em Tóquio, perto de si mas continuando a ver o namorado. Contudo, ele nada faz para ficar efetivamente com ela.

Sugita Kojō, o protagonista de Shōjobyō, (Doente por Meninas, 1907) é tão passivo quanto Takenaka Tokio, cujo pseudônimo é Kojō. Sugita, como Takenaka, é casado, tem filhos e está entediado com a vida conjugal. Vive da alegria de observar as meninas na rua, na condução, e se satisfaz com pequenas alegrias, como passar perto delas e ter breves momentos de contato. Kojō não chega a querer um envolvimento com alguma delas, mas sua fixação pelas moças e mulheres mais jovens é tão grande que o leva à morte. Distraído que está olhando para uma moça, cai nos trilhos e é atingido por um trem.

Em comparação com essas obras de Tayama Katai, as de Shimazaki Tōson apresentam maior detalhamento dos protagonistas, um número superior de personagens e enredos que abrangem um tempo da narrativa mais extenso. Kishimoto Sutekichi, de Haru (Primavera, 1907), e Koizumi Sankichi, de Ie (Família, 1910), do mesmo modo que Tokio e Kojō, revelam-se literatos no próprio texto: Kishimoto, por exemplo, submetendo sua mais recente obra à apreciação dos companheiros da revista que editam juntos, e Sutekichi pelos comentários dos parentes sobre a praticidade de seu trabalho, que pode ser levado com ele para onde for. No caso de Tokio, a obra como um todo está relacionada a sua carreira de escritor, em Kojō, sua profissão ligada às letras aparece na forma de lembrança da fisionomia dura do editor da revista em que trabalha.

Os títulos das duas obras de Tōson - Haru, "primavera", e Ie, "família" são, respectivamente, os próprios assuntos. Em Ie, a vida do protagonista gira mais em torno das relações familiares e daí o uso do nome Sankichi, que reproduz o tratamento informal, de proximidade. Já o protagonista de Haru, que tem a vida mais centralizada em sua relação com os amigos, literatos ou não, e conhecidos do que com a família, é denunciado pelo uso predominante de Kishimoto, seu sobrenome como indivíduo, com foco na primavera de sua vida, a primeira paixão e as amizades. Ao contrário, porém, da conotação positiva do título como o período 
alegre e cheio de esperanças, ironicamente ela é, para esse jovem, uma fase amarga e cheia de decepções, perdas e sofrimento.

O envolvimento de Kishimoto com Katsuko, aluna da escola em que ele começou a carreira como jovem professor, obriga-o a sair em viagem e manter-se afastado dos familiares e dos amigos. Ao retornar, consegue encontros furtivos com ela, arranjados pelo amigo, sem que ao menos ele os tenha solicitado. É incapaz de tomar qualquer iniciativa durante o encontro e só depois o sorriso, os gestos e as palavras dela são relembrados longamente, em detalhes. Sua atitude é de aceitação. Katsuko já tem um noivo que admira e, apesar de desejarem que a relação entre eles fosse possível e aceita pela família e pela sociedade, Kishimoto não the pede em momento nenhum que abandone o noivo, nem é essa a intenção da moça. Ela também sofre como ele por esse amor impossível, casa-se com o noivo a quem estava prometida e morre precocemente, mas sua vida com Kishimoto é inconcebível para ela.

$\mathrm{Na}$ carreira literária, Kishimoto sente-se inferior em relação aos companheiros. Aoki é alvo de seu respeito, dele são as obras apresentadas textualmente, e os poemas e obras que ele admira são os transcritos na narrativa. A vida desse amigo que se suicida também é a que ocupa maior número de páginas entre as partes destinadas às demais personagens. $\mathrm{Na}$ ocasião em que Kishimoto ficou desesperado e andou sem rumo, pensando até na morte, sendo acolhido pelo casal Aoki, o amigo também vivia uma situação difícil. Depois de uma separação temporária, em função das dificuldades financeiras, Misao, esposa de Aoki, havia acabado de voltar para junto dele e não conseguia entender porque o marido era incapaz de desfrutar da alegria de estar com a família. Aoki dava aulas e ajudava um missionário com algumas tarefas, mas não produzia nada de seu trabalho. Quando tentava escrever, sentia dores de cabeça e ia deixando os trabalhos inacabados. Para Aoki, o país é apenas um túmulo para os jovens, e Kishimoto chega a estranhar uma ocasião em que o vê sério como nunca, fazendo ataques a vários pensamentos presos aos velhos costumes e formalidades. Se destruíssem tudo, talvez algo novo pudesse surgir. Misao, por sua vez, vivia preocupada com o marido improdutivo no trabalho de que tanto gostava. A doença dele era invisível. Mostrava-se bem na companhia 
dos amigos, mas sozinho não tinha ânimo para nada, e Misao chegou a dizer a Kishimoto que ele se parecia muito com o marido.

Nessa obra, o protagonista é impotente diante das dificuldades da vida. Seus pensamentos e anseios são conhecidos por intermédio do amigo Aoki, que manifesta suas insatisfações muito mais do que ele, e vive encurralado, sem nunca achar uma solução para seus problemas, até que acaba pondo um fim à vida. Seu pensamento pode ser visto em passagens como "Aoki sentiu uma negligência muda, mas ao se comparar com o amigo bem sucedido, não se sentiu inferior", 4 quando está andando com Kishimoto na rua e um ex-colega do curso de Ciências Políticas passa com ar de superioridade em uma carruagem, ou quando Aoki deixa de lecionar e de escrever e responde a Ichikawa, que lhe perguntara se não tinha nada para publicar na revista: "Se me mandarem, escrevo o quanto for necessário. Por mais que escreva, não é a mesma coisa?". 5

Depois do caso com a aluna Katsuko, fato que o obrigara a sair de casa, com vontade até de morrer, Kishimoto passa um longo tempo na região oeste. De volta a Tóquio, Tamisuke, o irmão mais velho, recebe-o bem e acompanha-o até a casa do tio que o criara desde menino e aguardava ansioso por seu retorno. Durante sua ausência, a mãe e os irmãos haviam deixado a terra natal para morar com Tamisuke na capital; como o irmão fora preso por utilizar títulos públicos falsos por influência dos patrões, Kishimoto retorna ao seio familiar, que deixara aos dez anos de idade. A partir de então, irá atender ao pedido da mãe e da cunhada e manter Tamisuke animado e forte, até que seja solto, e acompanhar o longo período de clausura desse irmão, que não tem a menor noção das conseqüências sofridas por toda a família desde sua detenção. O que temos na vida do protagonista é o enfrentamento da realidade mais dura do adulto, que sem sombra de dúvida leva-o ao amadurecimento, mas com momentos de prazer e de alegria quase nulos.

Já Sankichi é um jovem escritor em início de carreira, penúltimo filho da família Koizumi, que tenta manter a ajuda mútua entre os irmãos depois da morte dos pais. De um modo geral, as demais personagens de Ie desempenham papéis de igual

\footnotetext{
${ }^{4}$ Tradução nossa, Haru, p.347.

${ }^{5}$ Idem, p.348.
} 
relevância, mostrando a constituição familiar e os problemas enfrentados com a chegada dos novos tempos. O protagonista desempenha suas funções de componente da família e sofre a tristeza de ver a ruína da família Hashimoto, à qual pertence Otane, a irmã mais velha, abandonada pelo marido, que parte para a Manchúria e enfrenta o desgosto de ver o primogênito Kōsaku e a nora mudarem todo o método de trabalho construído durante longos anos. Além disso, ela perde também Shōta, o filho caçula que era a sua esperança e que morre vítima de doença.

O próprio Sankichi também tem uma vida de sofrimento ao formar nova família junto com Oyuki, em casamento arranjado por Minoru, o irmão mais velho. Após o casamento, opta por viver no interior como professor e lá descobre que, antes de se casar, a esposa mantinha uma paixão por Tsutomu, que acaba tornando-se seu cunhado ao casar-se com a irmã mais nova dela. Sankichi pensa em separação. Mesmo após o nascimento de Ofusa, a primeira filha, mantém o desejo de desfazer a família, mas o irmão faz que ele desista. Continua com Oyuki, com quem tem uma prole numerosa, três meninas e três meninos, sendo que as três primeiras filhas falecem após o nascimento do quarto filho, quando ele já voltara a morar em Tóquio a pedido de um amigo e de um jornalista. Sankichi pensa em conservar um amor de irmão com Oyuki e volta para casa satisfeito depois de levá-la a um restaurante francês, mas percebe que depois de tanto tempo a mulher ainda não entende o que ele pensa.

Minoru, o irmão mais velho, é preso e, depois de libertado, vai para a Manchúria tentar a vida, como fizera Tatsuo depois de abandonar Otane; durante sua ausência, a filha Tsuruko falece e Oshun, sua outra filha, não pode ser a sucessora da família porque já estava prometida em casamento. Sōsuke, o terceiro irmão, tem problemas mentais e vive na dependência dos irmãos mais velhos. Quando o irmão Morihiko vem pedir dinheiro emprestado, Sankichi sugere a ele que pare de ajudar os outros e refaça sua vida no interior: "Nós sempre estamos carregando a velha família". 6 O protagonista de $I e$ acompanha os acontecimentos, mantém-se como expectador, vendo sua vida e a de sua família passar.

\footnotetext{
${ }^{6}$ Tradução nossa, Ie, p. 467.
} 
O dilema de Sasamura em Kabi (Bolor, 1912) também se passa na esfera familiar. Ainda sem estabilidade financeira como escritor, pensa em constituir sua própria família e acaba por formá-la meio ao acaso, mas não se trata de uma história de amor com uma relação planejada. Conhece Ogin, filha da senhora que o ajuda com os afazeres domésticos, depois que se muda para a casa construída por um amigo. Ogin já era separada, e os dois acabam tendo um envolvimento quando a senhora vai cuidar de um irmão enfermo no interior. Ogin engravida, e o menino Shōichi nasce contra a vontade de Sasamura. Ele tem a intenção de dar o filho para adoção e de não ficar com Ogin, mas entre propostas de casamento e de separação Ogin engravida novamente, dessa vez dando à luz uma menina. Logo depois, Shōichi adoece e precisa ser internado, exigindo muita dedicação e amor dos pais, que continuam juntos levados pelas circunstâncias.

Essa obra narra um período decisivo para o protagonista: o início de uma vida de responsabilidades e compromissos que esse escritor ainda em início de carreira reluta em assumir. Sasamura mostra-se permanentemente insatisfeito em relação a Ogin, seja pelas vontades materiais que ele não pode atender, seja pelos inconvenientes que a família dela causa a ele. Ogin, apesar de pouco instruída, é uma boa dona de casa e mãe dedicada. Após dar à luz a segunda criança, ela perde o viço e o encanto. Em Sasamura, temos a figura de um homem despojado dos valores tão caros para Ogin, como seguir as tradições e preservar a imagem. Só que Sasamura não dá a conhecer diretamente quais são seus valores. É um homem acuado, incapaz de agir e de enfrentar a vida, que não sabe impor aos outros o que deseja para si mesmo.

As famílias de Ogin e de Sasamura são do interior e vêem, na cidade grande, uma oportunidade não encontrada em suas regiões para ganhar o sustento. É o caso do sobrinho de Sasamura, do irmão e do pai de Ogin. Os amigos e companheiros de trabalho de Sasamura não possuem uma vida tão melhor que a dele. Alguns se sobressaem um pouco mais, como é o caso de I, que afinal só serve para Sasamura sentir-se diminuído: "Sente entusiasmo na voz de I e um vazio ainda maior". 
Não se trata de um mundo distante e inexistente, muito pelo contrário. As situações do dia-a-dia são bastante comuns. Sasamura sofre do estômago, tem dores de cabeça. A sogra quebra os dentes ao sofrer uma queda. Ogin e Shōichi freqüentam o dentista. Os últimos dias do professor $\mathrm{M}^{7}$ desenganado com câncer, são mostrados de modo bastante natural. Seus discípulos compartilham dos momentos finais da vida de M, pois isso faz parte da vida, assim como a doença de Shōichi, a perseguição de Ogin pelo ex-marido, a proximidade ou distância de Sasamura com o amigo Miyama, de acordo a situação - pequenas questões como dores de dente, compras, passeios.

Antes de conhecer Ogin, o irmão mais velho e a cunhada que moram em Osaka recomendam a Sasamura que se case; na viagem de volta, ele também presencia a felicidade conjugal de um velho amigo, na casa de quem se hospeda de passagem pela cidade de Quioto.

O texto apresenta uma forte relação de amizade e ajuda mútua entre os amigos, seja no caso dos não identificados, como o que transmite o recado de Yamada para que Sasamura ocupe a casa de K, amigo de infância e dono da casa, ainda universitário, ou no caso de um amigo mais velho a quem Sasamura auxilia nos estudos para o concurso em uma vaga num lugar distante, que lhe deixa utensílios domésticos para montar a casa nova ao deixar o alojamento. Com a família ocorre o mesmo. Um sobrinho do interior vem para estudar e mora com ele; os familiares de Ogin vêm para trabalhar e ficam alojados em sua casa. Sasamura hospeda também o amigo Miyama até ele arrumar uma casa na vizinhança. A relação de $\mathrm{M}$ com seus discípulos é enternecedora. Eles sempre se reúnem em sua casa e Sasamura ajuda o professor em seu trabalho.

Os relacionamentos pessoais e as descrições demasiadamente detalhadas deixam a narrativa confusa, prolixa, mas enfatizam a vida de penúria que revela o fracasso profissional de Sasamura. Na realidade, a família, ou pelo menos a mãe, que ficou no interior, espera pelo seu sucesso tanto ou mais que ele. Deseja dar o filho para adoção, mas acaba ficando com o menino por insistência de Ogin, que lhe

\footnotetext{
${ }^{7}$ Segundo informa a nota que acompanha a obra, trata-se de Ozaki Kōyō, mestre de Tokuda Shūsei e líder da Associação Ken’yū, um dos maiores e mais influentes círculos literários do Japão.
} 
mostra as vantagens de manter a família unida apesar dos sacrifícios que lhe são impostos. A vida de quem sai do interior em busca de uma oportunidade como escritor na cidade grande não é nada fácil. E, do mesmo modo que ele, pessoas das mais diversas profissões vão tentar uma nova vida nos centros urbanos.

O quadro de frustração da vida profissional e familiar do protagonista é angustiante. É a vida do dia-a-dia, sofrida, cheia de decepções, em meio à pobreza, à doença e às desavenças. Apesar de ser permeada de alguns poucos momentos de alegria, o que prevalece é o sofrimento e a tristeza. A descrição do filho é bastante negativa. Ogin é cheia de vontades que não podem ser satisfeitas. Sasamura sofre calado, impotente diante das amarguras que precisa enfrentar.

Mudam de casa diversas vezes, e a maioria delas são achados econômicos. Uma delas tem bolor nos armários, mas compensa pelo jardim agradável. Outra foi palco de dois assassinatos e serviu de depósito dos cadáveres até o antigo inquilino descobri-los. Os raros exemplos de felicidade que Sasamura pode proporcionar a Ogin são desejos comuns: a primeira visita ao santuário com o filho, ato muito comum no Japão, equivalente a um batismo, mas sem nenhum cerimonial, e a ida ao restaurante, para que ela saboreie um de seus pratos preferidos, o que torna mais evidente ainda a situação de pobreza enfrentada por essa família.

Sasamura mantém-se indeciso do começo ao fim. Ora pede Ogin em casamento, ora fala em separação, em dar os filhos para adoção, em cada qual ficar com um deles, em libertar Ogin e ele próprio cuidar dos filhos. É a doença de Shōichi e a observação dos sofrimentos alheios que acabam por unir o casal durante a hospitalização do menino.

O número de personagens de Kabi é bastante reduzido, como em Furo Oke (Banheira, 1924), que tem apenas o protagonista Tsushima, um escritor já idoso que sente próximo o final da vida, e sua esposa Sakuko. A obra centra-se na concretização de um desejo de longa data de um pai de família que durante muito tempo teve dificuldades em acomodar a família composta por dez pessoas e que, de modo inesperado, consegue uma casa no mesmo terreno que a sua, onde finalmente dispõe de espaço para a banheira ofuro, o que não é um luxo e sim uma necessidade do dia-a-dia. Tal sonho deve-se à impossibilidade de adquirir uma banheira nova, já 
que as duas anteriores foram danificadas há muito tempo, e ter que passar pelo desconforto de levar as crianças ao banho público.

Tsushima vive com os nervos à flor da pele e não consegue nem sequer concentrar-se numa conversa com outra pessoa. Os dias não têm graça, e ele fica insatisfeito em saber que as coisas boas, como as flores da primavera, só virão no ano seguinte. Assim, o momento em que a esposa está dando instruções ao pedreiro é alvo da atenção de Tsushima, e ao mesmo tempo motivo para irritação. O que se poderia chamar de diálogo ocorre uma única vez, quando ele reclama da voz alta que ela usava para falar com o pedreiro, pois ele conseguira ouvi-la da casa, do outro lado do terreno, e imaginou que os vizinhos também. Ela retruca, afirmando que não falara alto e que, mesmo que fosse o caso, não havia problema nenhum, pois não estava dizendo nada de mais. A insatisfação diante de pequenas coisas é decorrente de problemas financeiros e agravada pelas atitudes do cunhado, irmão mais novo da esposa, que apesar de ter recebido muitos cuidados de Tsushima causou-lhe prejuízos financeiros sem o menor pudor e gerou um clima de conflito com a esposa.

O protagonista sabe que as freqüentes dores de cabeça de Sakuko são decorrentes de suas agressões físicas, mas mesmo assim não consegue deixar de descontar sua irritação na esposa e atribui isso a fatores hereditários. Tsushima muda de idéia e destrói os preparativos feitos pelo pedreiro para iniciar a obra, e somente meio ano depois a banheira é instalada. O protagonista pergunta a si mesmo se não terá que fazer nenhuma outra até o final de sua vida, e imerso na banheira tem a impressão de que ela era seu ataúde. Observamos, nessa obra, um protagonista sem controle emocional, premido pelas privações do dia-a-dia que sofre há longos anos e que, quando consegue finalmente realizar um sonho simples, já atingiu a velhice e só lhe resta esperar a morte bater a sua porta.

O protagonista de Aishiki Chichi (Pai Digno de Compaixão, 1912), identificado por "ele", separou-se da esposa há pouco tempo. O filho de quatro anos fica sob os cuidados da avó, no interior, e não se faz nenhuma referência à mãe da criança. Enfermo e sozinho numa casa miserável, pequena e escura, na capital, o protagonista se lembra do filho olhando os aquários com peixes ornamentais. Tudo que tem limita-se a uma cama, uma escrivaninha e uma prateleira vazia feita de 
paulônia. Como os protagonistas das obras anteriores, é impotente até com o filho. Para não se sujeitar ao desafeto da criança e atender a seu desejo de ganhar uma roupa ocidental, desfaz-se da prateleira de paulônia, única peça que lhe restara para conseguir dinheiro a fim de manter-se vivo.

Essa obra narra algumas semanas da vida desse protagonista, que se intitula "pai digno de compaixão", e reitera ao longo do livro, de seis capítulos, que é kodoku na shijin, "poeta solitário", e kurai shijin, "poeta triste". A morte, sua ameaça iminente, é lembrada em diversas situações que o deixam inseguro. Só no sonho consegue ser positivo. Não tem perspectivas de longo prazo. Seu objetivo é imediato, conseguir dinheiro suficiente para ir ao litoral e por isso, mesmo com muito custo, começa a freqüentar a biblioteca, mas quatro ou cinco dias depois já acorda com febre e sente-se mal. O tempo passa e ele continua tentando escrever poemas. É um homem mergulhado em dificuldades e acomodado, incapaz de ter forças para superar e melhorar de vida.

Diferentemente dos protagonistas que não têm coragem de assumir a paixão fora do casamento, Keichirō, de Gake no Shita (Sob o Precipício, 1928), abandona a família em sua terra natal e foge com Chitose para Tóquio. No entanto, é incapaz de mostrar a ela que se preocupa com o filho e com o pai. Depois de algum tempo sem emprego fixo, quando já está sem dinheiro até para a condução, consegue trabalho num jornal e depois na revista Bungei. Resolvidos os problemas financeiros, são obrigados a deixar a moradia, que ficava num lugar conveniente, porque a proprietária torna-se rude com eles depois que Chitose acaba descobrindo por acaso um defeito físico que ela mantinha em segredo. Keichirō culpa Chitose e não tem coragem de enfrentar a situação. Procuram vários lugares para morar, mas só conseguem uma casa num lugar afastado, bem abaixo de um grande barranco, por indicação da esposa de um médico, freguesa de Chitose.

A infelicidade maior, porém, não era a casa que estava em péssimas condições, mas o amigo que morava no alto do barranco e que aconselhara Keichirō a não tomar decisões precipitadas, assumindo uma vida em comum com Chitose. Vem o arrependimento, e ele fica encurralado, sem poder conciliar a situação. Tem receio de que Chitose fique sabendo que a irmã o mantém informado sobre a ex- 
esposa, o filho, que tinha um tumor no cérebro, e o pai, já idoso, que ficaram em sua terra. Ao sonhar com o filho, que estaria chamando por ele, acorda preocupado, sem saber se Chitose o ouviu pronunciar o nome do menino. Chitose, no entanto, é compreensiva e pensa no futuro, na velhice. Acha que Keichirō precisa ir ao encontro do filho, para que não restem mágoas. Keichirō sente medo das conseqüências de seus atos e do ódio que a ex-esposa e o filho teriam dele. Ao mesmo tempo, preocupa-se com Chitose, que não tem ninguém que possa ampará-la. Ele está perdido e tenta encontrar consolo numa pintura de Rafael iluminada pelo sol.

Shimaki Shinkichi, de Kareki no Aru Fūkei (Paisagem com Árvores Secas, 1933), é um pintor de paisagens que criou um centro de pesquisas de pintura com alguns colegas, entre os quais Koizumi Keizō, amigo desde os tempos da escola de belas-artes, com talento para figuras humanas, a quem admira e respeita. Esse amigo faleceu, deixando inacabada um nu e um quadro que receberia o título de Paisagem com Árvores Secas, exatamente o nome dessa obra, que mostra a história do protagonista com esse amigo. É dele que Shimaki sempre se lembra e, enquanto está pintando uma paisagem com neve, recorda-se de um quadro de quatro ou cinco anos antes, no qual Koizumi utilizou a neve, e de alguns episódios dos 23 anos que conviveu com ele. Nos últimos tempos, o amigo, doente, havia deixado de participar dos encontros no centro de pesquisas.

A ênfase fica na surpresa que Shimaki tem quando ele está diante da "Paisagem com árvores secas" ainda em esboço, que é a nova experiência que Koizumi estava realizando para pintar paisagens. Apesar de se mostrar debilitado fisicamente nos últimos anos, ele trabalhava simultaneamente naquelas duas obras e também pintava um grande número de quadros sob encomenda, arranjados pela esposa, mas sua produção aumentara quantitativa e qualitativamente. Assim, nessa visita que faz à casa de Koizumi, o protagonista entendeu que não deveria baixar a guarda diante daqueles olhos caídos e da falsa modéstia do amigo. O protagonista mostra dois sentimentos paralelos em relação a ele: a tranqüilidade por Koizumi ser mais talentoso com as figuras humanas e daí manter-se no mesmo nível do colega de trabalho, a quem admira e respeita, e a preocupação de vê-lo como ameaça e como rival a partir do momento em que ele amplia seu leque de trabalho e passa a explorar 
as paisagens, pois, embora divida o espaço com o colega, o protagonista parece viver na sua sombra, sentindo-se sempre diminuído em relação a Koizumi, retratado como pessoa cativante e bem-sucedida.

A caminho do funeral de Koizumi, na companhia de outros dois amigos, Shimaki ouve os elogios que eles fazem ao falecido e fica absorto em seus pensamentos. Admira-se com o fato de uma pessoa tão perspicaz e habilidosa como Koizumi viver fechado em sua própria casa naqueles últimos anos, subjugado pelas vontades de sua esposa, e ainda assim deixar trabalhos maravilhosos. Há um misto de louvor e de inveja, e é por isso que, diante daqueles dois quadros inacabados expostos na sala em que estava o ataúde de Koizumi, Shimaki admira mais o Retrato de um Nu Feminino do que a Paisagem com Árvores Secas.

A obra Giwaku (Suspeita, 1913) tem um narrador-protagonista que é abandonado pela esposa e não se satisfaz até confirmar a suspeita de que ela fugiu com o estudante Kojima Sekijirō, que se hospedava em sua casa. Antes de sair à procura dela, reescreve, como consolo de todos os dias, a cena do momento em que será preso pelo homicídio da mulher. É tão passivo que somente dois anos depois vai à polícia solicitar a busca de Shin. Obcecado, ele procura por pistas da mulher na cidade de Nikkō, onde julga conseguir mais informações acerca de seu paradeiro. Sem disposição para ler ou escrever, consegue, com muito custo, arrumar o dinheiro; depois de meses de procura pelas hospedarias, ajudado por funcionários muito solícitos e já sem dinheiro nem para a refeição, consegue confirmar sua suspeita. Sente que sua vida tomou um rumo e um misto de alegria e de raiva invade seu coração. Encontra o cadastro em que consta o nome de sua mulher alterado para Suma, com o sobrenome do amante e com as idades alteradas. Não se incomoda em expor o fato vergonhoso às pessoas da hospedaria em que encontrou o registro da mulher e do amante nem de sofrer humilhações. A amargura daqueles dois anos desaparece, e ele fica aliviado diante da possibilidade de encontrá-los no endereço que constava no registro. Percebemos que mesmo diante dessa confirmação e de perceber por si mesmo que fora ingênuo demais em não perceber que Shin sentia atração pelo estudante há muito tempo, ele ainda continua a alimentar esperanças de encontrar a mulher. 
Como ocorre em Giwaku, o "eu” protagonista de Kurokami (Cabelos Negros, 1922) também vive atormentado pela suspeita; Essa obra fala sobre a sinceridade de uma gueixa de Quioto ao homem que propõe que deixe o trabalho para se casar. A profissão do protagonista não é revelada textualmente, mas trata-se de alguém que reside em Tóquio, distante cerca de $300 \mathrm{~km}$ de Quioto, com tempo disponível suficiente para ir ao encontro dela e ficar longos períodos fora da capital. Solitário, tem sede de ambiente familiar e sujeita-se a uma demorada espera pela decisão dela sobre o momento certo. O relacionamento já dura quatro anos, e eles trocam cartas. Quando finalmente parece que vão ficar juntos, em vez de alívio o protagonista começa a ter dúvidas maiores sobre o que haveria ocorrido nesses anos em que aguardava pela resposta.

Os diálogos em Kurokami restringem-se a conversas telefônicas, de uma ligação feita por ela para combinarem um local de encontro, e aos momentos do próprio encontro, que, na realidade, servem para protelar uma conversa séria e definitiva entre eles, principalmente pela vontade dela. No entanto, no último capítulo, criam uma tensão dramática no diálogo em que finalmente parecem falar de algum assunto específico, ou seja, da existência de um admirador casado e com filhos que se propusera a sustentá-la e de uma gravidez e nascimento supostamente falsos de uma menina. No entanto, como não era do feitio da mulher fazer brincadeiras com assuntos sérios, o protagonista martiriza-se pensando quem seria o pai e por que a criança não era dele. Quando está se lamentando pelo fato de ela, apesar de sua insistência, não ter abandonado a profissão a tempo de evitar problemas semelhantes, ela diz:

- Quer que eu lhe mostre a criança?

-Quero. Mostre-me. Onde está? É menina ou menino?

-É uma menina. Se você quer, vou buscá-la - disse, e levantou-se.

Fiquei pensando de onde ela a traria e fixei olhar nela enquanto me dava as costas, tirou uma caixa comprida que estava sobre o armário, abriu a tampa e tirou uma boneca típica de Quioto bem grande. 
- Que absurdo! Está me fazendo de tolo! - disse rindo em voz alta ao sentir que a agonia que trazia no peito havia se desfeito de imediato. ${ }^{8}$

O diálogo continua até o final da obra, como se dali por diante eles fossem realmente mantê-lo com freqüência, frente a frente, sem segredos. Mas a realidade é bem outra. Ele encontra fotos suspeitas de dois homens dentro do altar budista.

- Ei, quem são estes? - perguntei a ela que estava de costas guardando os quimonos.

Mal ela se virou, levantou-se na minha direção.

- Não é para ficar olhando essas coisas - disse meio contrariada e tomou aquelas fotos de minhas mãos. ${ }^{9}$

Esse é o fim de Kurokami. As suspeitas que o protagonista tinha da sinceridade da mulher até aumentam, mas nada indica que ele a deixará ou que tomará alguma atitude em relação ao engodo. Ele foi e continuará sendo vítima de sua própria passividade.

Em Kinosaki ni te (Em Kinosaki, 1917), o protagonista é levado a um período de repouso nas termas de Kinosaki, depois de um acidente de trem quase fatal. Faz o que lhe resta fazer: esperar o tempo para saber o resultado. Durante a estada, tem a oportunidade de refletir sobre a morte e constatar que teve mais sorte que a abelha, o rato e a lagartixa d'água que observou nas termas. Ele vê que poderia ter enfrentado qualquer das três situações que envolvem a morte desses animais. Poderia ter sido encontrado morto como a abelha e ficar ignorado por seus iguais, que continuariam com suas tarefas até que ele fosse levado para um local fora do alcance da visão deles; poderia sofrer a dor e a agonia que antecedem a morte premeditada, como aconteceu com o rato, que tinha um espeto atravessado na garganta e tentava desesperadamente fugir das pessoas que lhe arremessavam pedras; ou poderia ter uma morte acidental, como a da lagartixa d'água atingida por uma pedra que ele arremessou com o simples desejo de fazer que o animal voltasse para a água. No entanto, seu caso fora bem diferente. Não desenvolveu a doença que seria fatal e teve a vida poupada. Resignou-se e foi obediente na hora em que precisou aguardar, e recebeu com serenidade a noticia de que restabelecera a saúde. Submete-se às

\footnotetext{
${ }^{8}$ Tradução nossa, Kurokami, p. 372.
} 
circunstâncias como lhe é permitido e aguarda com paciência, sem desperdiçar o tempo. O protagonista de Kinosaki ni te tenta não mostrar sua impotência perante o destino mediante uma serenidade e aceitação dos fatos que estão fora da esfera de sua atuação.

Seguidor de Shiga, Ozaki Kazuo parece ter se inspirado nessa obra para escrever Mushi no Iroiro (Diversidade dos Insetos, 1948), fazendo reflexões pessoais por meio da observação de alguns animais. Trata-se de uma obra em primeira pessoa, que usa a comicidade para atenuar um assunto sério e desconhecido, vida e morte, questão enfrentada pelo "eu", narrador-protagonista da obra, quando está convalescendo da nevralgia e reumatismo no espaço restrito de sua casa, onde passa o tempo observando os insetos, que servem para uma reflexão sobre o comportamento deles e dos seres humanos. O protagonista mostra-se resignado com sua situação e reconhece-se na pulga, apesar de desejar ser a aranha, que suporta um longo tempo mesmo sem ter o que comer e, na primeira oportunidade escapa ligeira, ou como o zangão, que voa sem saber que é incapaz, desafiando as leis da física. Questiona se a liberdade existe e se a sua depende de quem a escreve, existe ao acaso ou é cerceada. A única certeza é a morte. Imagina se há alguém que o observa e o controla, assim como ele fez quando encontrou a aranha aprisionada na janela. Se esse ente existe ou somos nós mesmos que o fabricamos, ou ainda no qual nos transformamos, é algo que ninguém lhe pode ensinar. E encerra a narrativa com a façanha tragicômica de aprisionar as patas de uma mosca com as rugas da testa, levando a esposa e os filhos às gargalhadas. A situação cômica deixa-o malhumorado e não sem motivo. O alvo do riso vai além dessa situação momentânea de comicidade, é ele mesmo, que continua na incerteza e sob a ameaça da morte que pode vir a qualquer momento, sem que ele possa agir ou reagir.

Em Remon (O Limão, 1924), temos um protagonista quase sem perfil. É alguém que possui uma doença pulmonar, mas não atribui seu obscurantismo a ela e muito menos a qualquer possível distúrbio psicológico ou às dívidas que contraiu. É menos passivo que os protagonistas das obras anteriores, pelo menos no que se refere à criatividade. Ele age em seu mundo de faz-de-conta como se fosse uma criança que

\footnotetext{
${ }^{9}$ Idem, p. 373.
} 
brinca de plantar uma bomba - um limão californiano que, quando tocado, lhe proporcionou um frescor agradável, livrando-o do mal-estar - no lugar que mais apreciava antes de sentir a insatisfação aparentemente infundada que tomava conta de seu ser, a livraria Maruzen, para destruir tudo que incomodava o protagonista e dar a mesma sensação agradável proporcionada a ele pelo fruto. Nessa vida de degradação, que é sua realidade do momento, satisfaz seu sonho na esfera da imaginação. Associa os vidros coloridos que vê pela cidade à infância reprimida pelos pais, mas também protegida por eles, quando vivia sem as responsabilidades do adulto no qual se tornou.

O narrador-protagonista de $\operatorname{Koi}$ (A Carpa, 1926) louva Aoki Nanpachi por meio dos cuidados que dispensa a uma carpa que esse amigo lhe trouxe de uma pescaria, sobretudo depois de seu falecimento. Para isso, utiliza o próprio título da obra, A Carpa, que faz homofonia com "amor" em japonês. No final, aproveita o gelo e a neve para representar a cor da carpa e da pureza de seus sentimentos pelo amigo. A dedicação pelo peixe e a demonstração de carinho por ele é mostrado com o trabalho que o protagonista tem em "abrigar" a carpa. Depois de deixá-la no lago do alojamento que ocupava, levou oito dias para conseguir pescá-la quando se mudou; deixou-a no lago da casa da namorada de Aoki por não ter outro abrigo para a carpa; quando o amigo faleceu, seis anos mais tarde, precisou de vários dias para resgatá-la. Solta-a no lago artificial da Universidade Waseda, e no verão, enquanto esteve desempregado, ia à tarde passar o tempo junto ao lago, mas sem saber se a carpa continuava viva. Acha o peixe nadando como se fosse um rei, seguido por outros peixes, e fica orgulhoso e emocionado. Suas visitas prosseguem durante o outono, mesmo quando a visão fica impedida pelas folhas que cobrem a água, e também no inverno, quando a superfície do lago fica congelada. Certa manhã de neve, ele pega uma vara de bambu e resolve desenhar um peixe com mais de cinco metros na superfície do lago, seguido por outros peixes menores, uns sem nadadeiras, outros sem olhos ou boca. É assim que ele homenageia o amigo, pela sublimação da carpa branca seguida pelos peixes imperfeitos. Nesse ato de louvor por Aoki, o protagonista diminui a si mesmo como se fosse um dos peixes imperfeitos seguindo a magnífica carpa branca. 
O narrador-protagonista de Fugaku Hyakkei (As Cem Paisagens do Monte Fuji, 1939) narra sua ida no outono de 1938 a Misaka Tōge, a 1300 m de altitude, considerada uma das três vistas mais famosas do Monte Fuji, onde visita Ibuse Masuji, ${ }^{10}$ que estava trabalhando no local desde o verão e que o aguardava para ir a Kōfu apresentar-lhe uma moça. Durante os dois meses aproximadamente em que permanece no local para escrever, vai mudando o pensamento que tinha em relação ao monte sagrado a cada experiência nova. Quando chegou ao local, e o viu pela primeira vez, não gostou; na segunda vez, quando subiu a $1700 \mathrm{~m}$ com Ibuse, não pôde vê-lo por causa da cerração. O primeiro sentimento positivo lhe vem exatamente quando está na casa da moça, e Ibuse chama-lhe a atenção para uma foto do monte na parede atrás dele. Ao voltar para a posição anterior, depois de ver a foto, consegue observar bem o rosto da moça, que não conseguira enxergar quando entrou, e fica agradecido ao Fuji.

A segunda ocasião em que simpatiza com o Monte Fuji ocorre depois da visita de Nitta, um amigo romântico de 25 anos de idade e seus amigos. Nittao comenta que estava admirado de ver que ele era sério e firme, pois Sato Haruo ${ }^{11}$ dizia, num de seus romances, que ele era decadente e de natureza destrutiva. Chamado de mestre, sente-se digno do título pelo menos no tocante ao sofrimento pelo qual já passou. Indo com os jovens a Yoshida, uma cidade comprida e com muitos lagos, conta-lhes sobre a protagonista de um romance de Maupassant, que todas as noites atravessava um rio a nado para ir ao encontro de seu amado príncipe, e discutem sobre uma peça japonesa em que um moço fica separado por um rio de Kiyohime, sua amada e corajosa princesa de 14 anos. Naquela noite, não conseguiu dormir. O Fuji estava maravilhoso no céu enluarado e ele saiu andando, cheio de auto-estima. Nem se importou com a moedeira que deixara cair e resgatou-a, fazendo o mesmo trajeto de volta para a hospedaria. Contou tudo o que aconteceu durante esse passeio à dona da hospedaria de Misaka, e ela o acordou, numa manhã de neve, para que ele passasse a gostar da paisagem do Fuji visto do local.

${ }^{10} \mathrm{O}$ autor utiliza o nome do próprio escritor Ibuse Masuji, que serviu de protótipo para essa personagem, e o texto insere seu nome como se dispensasse apresentações.

${ }^{11} \mathrm{O}$ nome dessa personagem tem um protótipo com o mesmo nome na vida real, que é o escritor Satō Haruo, e na obra ele é mencionado sem qualquer explicação, como personalidade bastante conhecida. 
O protagonista achou muito bom e jogou sementes de prímula amarela ${ }^{12}$ na entrada da hospedaria para que florissem no ano seguinte. Passou a perceber a existência dessa planta quando desceu a montanha para pegar correspondências e ao voltar de ônibus para a hospedaria. Nele, uma senhora de aproximadamente 60 anos estava sentada afastada dos demais passageiros e olhava para o penhasco, ignorando as explicações que a guia do ônibus dava sobre o Monte Fuji. Ela disse: "Olha, prímulas. E o protagonista sentou-se a seu lado, para olhar aquela flor amarela que desabrocha no verão e lhe mostrar que também compartilhava de sua indiferença pelo Fuji. Sentimento semelhante é descrito também enquanto tentava prosseguir com o trabalho que não avançava, e sentia-se atraído mais pelas folhas vermelhas e outonais da montanha do que pelo Fuji. Por isso, achou que não valia a pena escalar as montanhas da região para apreciá-lo. Seu sentimento em relação ao visual do Fuji não mudou muito; o que mudou foi o significado que ele passou a ter. Depois de ser alvo de gratidão, o monte transformou-se numa espécie de divindade, à qual ele fez pedidos de proteção. Foi essa a postura que tomou em relação ao grupo de mulheres que chegou à hospedaria no final de outubro. Pediu ao Fuji que cuidasse delas.

Nessa época, seu casamento com a moça apresentada por Ibuse já estava acertado, e ele sabia que não poderia contar com a ajuda financeira da família. Precisaria de pelo menos 100 ienes, e desceu a montanha até à casa da moça para contar que não receberia auxílio nenhum. Recebeu a compreensão da futura sogra, que se sentiu aliviada em saber que a família dele queria apenas que ele arcasse com os gastos, e não se colocou contra o casamento. Nesse dia, sua noiva fez uma brincadeira com ele e esse momento de felicidade ocorreu diante do Monte Fuji. O casamento seria organizado por um amigo veterano, uma cerimônia simples, mas, para ele, muito nobre. No dia anterior ao de sua partida, chegaram duas moças que ficaram magnetizadas ao olhar para o monte e lhe pediram para tirar uma foto. Diante do imenso Fuji e das duas papoulas - as moças vestidas de casaco vermelho

\footnotetext{
${ }^{12}$ O nome utilizado em japonês significa "erva que olha a lua", e apreciar a lua no outono, estação em que se insere essa narrativa de Dazai, é um hábito cultivado pelos japoneses desde os tempos antigos. Essa planta natural da América do Norte que atinge cerca de $60 \mathrm{~cm}$ dá flores de várias cores, mas são as amarelas que, no verão, montam um lindo cenário no sopé do Monte Fuji e que, ironicamente, afirmam "não olhar" para o tão soberbo monte. V. Anexo, Imagem 1.
} 
-, ele não hesitou em focalizar só o monte e tirar a foto, despedindo-se e agradecendo a ele.

Em Sei Yohane Byōin ni te (No Hospital São João, 1946), o “eu” protagonista relata o período em que acompanha o período de internação da esposa cega e já bastante debilitada no Hospital São João até conseguir sua transferência para um hospital público. As alegrias do dia-a-dia giram em torno dos alimentos, e os desprazeres também. A paciente recebe as refeições do hospital e o protagonista leva sua refeição preparada de casa com os alimentos distribuídos pelo governo. Vez ou outra consegue algo diferente, repartido por algum vizinho, e aproveita para dividir o presente valioso com a esposa. Assim, ora presenciamos a beleza do espírito de compartilhar a comida, ora a descrição dos ressentimentos de não querer ceder o que pertence a cada um.

Há momentos de reflexão sobre os enganos do julgamento, quando ele é confundido com um dos doentes mentais do hospital e quando, por sua vez, pensa que um dos internos é uma pessoa sã. Da mesma forma que ocorrem esses erros de juízo e ao contrário do que deveria acontecer, é ele quem tira o proveito maior com as idas que faz ao hospital para ajudar a esposa. Ela separa para o marido parte do que é mais raro, como o leite, e ele sente-se favorecido, pois na época de escassez em que vivem é graças a ela, a sua necessidade de hospitalização, que ele consegue se manter melhor do que poderia estar. $\mathrm{Na}$ ocasião em que se atrasou e encontrou o hospital fechado, é ela quem o auxilia a entrar. As posições se invertem entre o ajudante e o ajudado. Apesar de querer ser mais amável com a esposa, de se anular por ela, o protagonista fica desnutrido e cansado, sem condições de continuar com o acompanhamento quando a esposa é transferida para o hospital público, e a obra termina antes de mostrar o inevitável desfecho infeliz para os dois.

Dessa maneira, o protagonista do Romance do Eu geralmente é um homem ligado ao ramo das letras, um literato: escritor, poeta ou redator - mais raramente, um pintor. Em geral, não são bem sucedidos e enfrentam dificuldades financeiras. $\mathrm{O}$ grande ponto em comum é sua natureza submissa, passiva. Incapaz de reagir, o protagonista é vítima de sua própria inércia, que gera insatisfações e desgraças. $\mathrm{O}$ 
protagonista e os acontecimentos relativos a sua vida são o foco, mas não há qualquer enaltecimento em relação a sua pessoa. Ele é pequeno, impotente.

Encontramos nesses protagonistas "o caráter como interação personagemautor" e "o tipo como forma de interação personagem-autor" a que se refere Bakhtin. O estudioso denomina

caráter uma forma de correlação entre o autor e a personagem, que realiza o desígnio de criar o todo da personagem como indivíduo determinado, e note-se que esse designio é fundamental: desde o início a personagem nos é dada como um todo e desde o início o ativismo do autor se movimenta nas fronteiras essenciais dela; tudo é percebido como um elemento de caracterização da personagem, tem função caracteriológica, tudo se resume e visa a responder a pergunta: quem é ela? ${ }^{13}$.

O protagonista do Romance do Eu segue o tipo de construção do caráter romântico, e "a personagem é passiva, apenas passa pela vida", ${ }^{14}$ como foi possível constatar nas obras estudadas. Da mesma forma, o protagonista desse gênero japonês mostra-se como o descreve Bakhtin: "o tipo (está) no presente; o ambiente do caráter é um tanto simbolizado, o mundo material em volta do tipo tem foros de inventário. O tipo é a posição passiva de um indivíduo coletivo".

Tal protagonista é o resultado de uma paródia das obras estrangeiras. $\mathrm{Na}$ tentativa de criar obras em prosa que se assemelhassem aos romances estrangeiros, valorizados no processo de modernização e ocidentalização do Japão, os escritores recorreram à imitação; ao fazê-lo, reproduzem o que já existia na tradição japonesa vinda dos diários e dos ensaios da literatura clássica. Retratam as tristezas de suas vidas. Atingem o leitor pelo sentimento de compaixão que despertam nele e pela identificação deles com o protagonista, que é impotente diante das circunstâncias. As demais personagens podem ser mais fortes, mais talentosas e terem mais sucesso; eles, não.

Nas obras, as mulheres assumem um papel de maior firmeza e decisão que os protagonistas, defendendo uma mudança social com a valorização das mulheres. Elas são caracterizadas como figuras que estão se emancipando, modelos de novas

${ }^{13}$ Mikhail BAKHTIN, Estética da Criação Verbal, p. 159-60. 
mulheres que surgem no cenário japonês e são apoiadas pelos escritores. O número de personagens do Romance do $\mathrm{Eu}$, quando não se limita ao próprio narradorprotagonista, é reduzido, e a maioria das obras traz figuras femininas marcantes.

Comecemos por Yoshiko, de Futon, que é modelo da nova mulher, condizente com a modernidade da época. Ela é uma jovem interiorana de 19 anos, natural de Niimi-machi, em Bitchu, mas conhece as alegrias do Natal, sabe rezar e estudou em Kōbe, num internato feminino cristão bem liberal em matéria de literatura, fazendo muitas leituras e aprendendo a criar um ideal para si. Escreve bem, está disposta a enfrentar as dificuldades da carreira pretendida de escritora e é esperta. Mais do que bela, tem um rosto expressivo, diferente das mulheres de quatro ou cinco anos antes, que só sabiam demonstrar ira ou alegria com três ou quatro tipos de expressões diferentes. Além de ter um coração jovem e ser apaixonada por histórias românticas, seus olhos são expressivos e cheios de brilho; usa o penteado moderno da época, conhecido pelo nome de hisashigami; além de estar sempre perfumada, enfeita-se com pentes e laços. É vista pelo protagonista de Futon como a “nova” mulher Anna Mahr, personagem de Einsame Meschen.

Para realçar ainda mais as qualidades desejadas para a nova geração de mulheres japonesas, a esposa do protagonista é dada a conhecer na comparação com Yoshiko e com as outras esposas jovens de seus amigos. Representa a mulher antiga, que nem nome tem na obra, a namorada de antigamente que recebeu educação feminina tradicional e tem vergonha de andar ao lado do marido. Os temores dessa mulher em relação à jovem discípula do marido aparecem, mas de modo bastante inexpressivo, comprovando sua natureza dócil e obediente, fiel e casta.

Em Haru, temos mulheres fortes e batalhadoras, como Mineko, a quem Kishimoto pediu auxílio financeiro, e Tsutsumi, a jovem poetisa que estreou na revista dos companheiros do protagonista. A irmã mais velha compunha poemas waka e passara a escrever romances, e a família era mantida pela força das mulheres. Misao casou-se com Aoki contra a vontade da família dele, e é o esteio do marido. Mantém-se firme mesmo diante da proposta da sogra de que ela volte para a casa de seus pais e ajuda o marido com as aulas que dá para as moças da vizinhança, mas

\footnotetext{
${ }^{14}$ Ibidem, p. 166.
} 
sabe que isso é insuficiente para o sustento e incentiva Aoki para que ele consiga sair para o trabalho.

Ogin, de Kabi, não é mencionada como a mulher moderna, mas é ela quem resolve deixar o marido e assumir o filho com Sasamura para criar uma família. Sai à procura do que acredita ser necessário, e mesmo presa aos costumes tradicionais quer desfrutar do prazer de mantê-los e dar o melhor que pode a seus filhos.

Enquanto o protagonista de Giwaku faz papel de otário durante dois anos, Shin, a esposa que o abandonou, teve a coragem de assumir um novo amor com um estudante mais jovem que ela e de deixar o marido sem que ele percebesse que estava sendo enganado.

Os defeitos das mulheres são minimizados, não são eles os motivos da insatisfação ou do sofrimento do protagonista. O problema está nele mesmo, na sua falta de ação. Quando se põe em evidência seu interesse pelas mulheres, podemos associá-lo à busca do que antes estava a seu alcance, do que lhe era permitido e deixou de sê-lo; que passou a ser um desvio de conduta moral, como no caso de Shōjo Byō.

A mulher como objeto do desejo e a família como responsabilidade indesejada e causa do sofrimento masculino fazem parte dos aspectos focalizados por algumas obras do Romance do Eu. Mais do que uma auto-revelação, como diz a estudiosa alemã Hijiya-Kirschnereit, essas obras assemelham-se a um desabafo por escrito feito junto a amigos e colegas que inicialmente compunham os círculos literários japoneses, uma reunião de colegas de uma faculdade ou de grupos organizados em torno de um escritor ou poeta renomado.

Constatamos a descrição dos desejos libidinosos masculinos das obras naturalistas japonesas como vergonha na vida conjugal. Nesse aspecto, é possível notar um aproveitamento da confissão cristã utilizadas pelos fiéis para se redimir dos pecados, com a diferença de que a confissão é feita em segredo no confessionário a um representante de Deus, e os autores representam a revelação de seus segredos diante do público, como se quisessem obter a compreensão dos leitores.

Em termos históricos, no entanto, sabe-se que o Japão foi tradicionalmente poligâmico, e a mudança para o sistema monogâmico ocorrida após a abertura para o 
Ocidente no final do século XIX, principalmente em função da moralidade sexual cristã, traz novas regras nas relações matrimoniais, criando uma realidade nova para o povo japonês, especialmente para os homens. Nesse sentido, vale observar que não há Romances do $\mathrm{Eu}$ escritos por mulheres - pelo menos os críticos e estudiosos japoneses não apontam romancistas do eu femininas nem obras suas, pelo menos na fase inicial.

Obviamente, nenhuma mudança ou regra de conduta é aceita e praticada de imediato e com tranqüilidade, e as obras já vistas de Katai mostram o conflito interior vivido pelos homens com a incorporação desses novos conceitos. Isso pode ser constatado, ainda, pela existência, desde 1868, de uma instituição cristã feminina de moralização que, de um lado, lutou pela lei seca; de outro, por mudanças nos códigos Civil e Penal, incluindo o pedido de adoção de um só nome, da monogamia e do controle das prostitutas estrangeiras. Em 1916, formou-se, inclusive, um grupo dentro da instituição para erradicar o sistema de reconhecimento legal de amantes.

Tal mudança vai de encontro com o homem japonês, porque gera repressão sexual e moral. Cria-se um atrito entre o desejo de manter o casamento e a família e, ao mesmo tempo, de desfrutar do prazer de amar e de satisfazer os instintos sexuais. A degradação está mais no aspecto social e ético do que no nível socioeconômico, como acontece no Naturalismo ocidental, embora este último também apareça sob a forma da pobreza dos escritores como causa de seu sofrimento e de seus familiares.

Encontramos, assim, o homem casado que se apaixona por uma jovem em Futon; o homem casado que é louco pelas moças e morre atropelado enquanto olha para uma delas em Shōjo Byō; o homem que deixa a família no interior para viver com a amante, mas precisa passar pelo sofrimento de não ver mais o filho, em Gake no Shita; o homem solteiro que é obrigado a casar-se com a mãe de seu filho e, mesmo contra a vontade, continuar com a família, em Kabi.

As revelações sobre os escândalos amorosos e sexuais poderiam ser alvo de interesse geral naquela época, quando fazê-lo publicamente por escrito ainda era novidade, mas o mais interessante nessas obras é que elas parodiam as obras naturalistas ocidentais, inserindo elementos próprios dos japoneses que obviamente não viviam as mesmas condições de produção histórica e social dos países 
estrangeiros que tentavam seguir. Sujeitos à repressão ideológica, os escritores ficaram limitados e retrataram a vida sóciopolítica do Japão, voltando-se para a escrita de si mesmos. No entanto, esse ato de reclusão em seus sentimentos torna-se revelador da própria situação histórica que eles vivenciaram, num país que tenta alcançar a riqueza material e o avanço tecnológico ocidental para se manter como independente e progressista, com o sacrifício do povo em prol de uma política expansionista militar.

É por isso que o protagonista do Romance do Eu sente mais e pensa menos, pois até o final da Segunda Guerra Mundial o japonês teve sua liberdade de pensamento e de expressão controlada. Ele é fadado a ficar circunscrito no espaço restrito da família, dos amigos, ou seja, na esfera particular, e é a visão desse ambiente que as obras nos proporcionam.

Apesar das críticas bastante comuns ao Romance do Eu pela falta de caracterização das personagens, Haru, por exemplo, é uma obra que não se encaixa nesse modelo. Descreve os traços físicos, as vestes, a aparência, a natureza e as atitudes de um número grande de personagens, que não são meros figurantes. Cada personagem tem sua história, e não apenas o protagonista. $\mathrm{O}$ narrador desenvolve os acontecimentos ao longo dos 132 capítulos numa seqüência paralela ao fio condutor da história, que é a vida de Kishimoto, mas focaliza a vida de uma e outra personagem, que têm suas histórias interligadas, em especial a de Aoki. A caracterização de Kishimoto e de seus familiares, bem como a dos amigos Aoki, Ichikawa e Suge e os irmãos Okami, é bastante elaborada, bem como das esposas e namoradas. Mesmo sem as caracterizações do tipo de Haru, a referida crítica não é devidamente adequada, pois a obra literária é muito mais ampla e dispõe de infinitas possibilidades para a composição de suas personagens, e as obras mostram o despojamento e a criatividade dos escritores nessas variedades desconhecidas e inovadoras para aquela situação. 


\section{Narrador e foco narrativo}

O Romance do $\mathrm{Eu}$ apresenta duas variantes narrativas: a primeira e a terceira pessoa do singular. As obras iniciais foram escritas na terceira pessoa, muito provavelmente estimuladas pelos romances estrangeiros que chegaram ao Japão da época, mas é interessante observar que essa forma, mais adequada para criar um distanciamento entre o autor e o protagonista, foi a escolhida para apresentar um conteúdo que se pretende autobiográfico. As obras em terceira pessoa apresentam resultados mais diversificados na técnica narrativa. Em Futon, por exemplo, predomina a narração em terceira pessoa, mas há uma mistura de autor onisciente intruso e narrador onisciente neutro, que se transformam em onisciência seletiva múltipla. O primeiro capítulo começa pelo final da história, com a reflexão do protagonista Takenaka Tokio sobre o malogro com sua jovem discípula, bonita, inteligente e moderna, vinda do interior. O fato já havia ocorrido há dois ou três dias, mas permanece o questionamento sobre o que ele poderia ter feito naqueles três anos antes de perdê-la. Focaliza o protagonista em sua rotina, a caminho do trabalho, enquanto ele se desespera, indignado com o resultado. Acompanhamos sua "descida" denotativa e conotativa, decepcionado com o desfecho dessa história que vem diretamente de sua mente por meio de uma seqüência de vários parágrafos em sumário sobre seu estado psicológico e as impressões que os fatos e as pessoas deixaram.

A narrativa em terceira pessoa cita o pensamento do protagonista Takenaka Tokio, identificado nesse momento como "ele". É um misto de sentimento de indignação consigo mesmo, pai de família, por ter-se envolvido com a discípula Yoshiko, então identificada como "ela", e de esperança de que a moça o amasse. Reconhecemos aí o narrador onisciente seletivo múltiplo.

Tais exemplos, em que o autor traduz detalhadamente os pensamentos, percepções e pensamentos filtrados pela mente do protagonista, podem ser encontrados ao longo da obra. Um exemplo está logo no início:

Inúmeras cartas cheias de sentimento - uma relação a dois nada comum. Não virou uma paixão desenfreada porque envolvia esposa, filhos, sociedade e a 
relação entre mestre e discípula, mas por trás do coração palpitante durante as conversas e do brilho nos olhares trocados, havia o furor de uma tempestade. Uma única oportunidade seria suficiente para romper de uma vez por todas com a moral perante a esposa e os filhos, a sociedade e também essa relação do mestre com a sua discipula. ${ }^{15}$

A exemplo de muitas outras pequenas intromissões do narrador, como " $\mathrm{Um}$ literato que redige livros de geografia?", ${ }^{16}$ esse trecho é intercalado por "Pelo menos, o homem assim acreditava.". ${ }^{17}$ E prossegue com o sumário na mesma linha, apresentando a história pela visão do protagonista:

Não é fácil entender a psicologia de uma moça jovem. Aquele amor caloroso e alentador poderia ser resultado de um desenrolar natural das coisas, muito peculiar às mulheres; a beleza do olhar expressivo, a atitude afetuosa, tudo poderia seria inconsciente, desprovido de sentido, como a gentileza que a flor, na natureza, faz a quem a vê. Mesmo que ela o amasse, estivesse apaixonada, ele era mestre, e ela, discípula, ele tinha esposa e filhos, ela era uma bela flor no auge do esplendor. Não havia condições de nenhum dos dois se permitirem agir conscientemente. Ou melhor, pensando de modo mais ousado, aquela carta ardente revelava por inteiro o seu coração hesitante, como se a força da natureza pressionasse este corpo aqui, e quando veio transmitir seu último sentimento, este corpo não decifrou esse mistério para ela. Que condições ela teria de se aproximar de modo ainda mais aberto se a natureza da mulher é ser discreta. Pode ser que movida por essa psicologia, ela tenha se decepcionado e levada a fazer tudo o que fez. ${ }^{18}$

Nesse trecho, o pronome oblíquo "o" e o pronome pessoal "ele" são revestidos pela própria ambigüidade ou pela natureza contextual característica da língua japonesa, que utiliza o termo jibun para referir-se a si mesmo ou a outrem. Assim, poderíamos "ler" também como "mesmo que ela me amasse, estivesse apaixonada por mim (aqui preferimos omitir o objeto indireto na primeira tradução), eu era o mestre e ela, a discípula, eu tinha esposa e filhos, ela era uma bela flor no auge do esplendor". Da mesma maneira, "este corpo" no contexto pode ser visto

\footnotetext{
${ }^{15}$ Tradução nossa, Futon, p.71.

${ }^{16}$ Idem, p. 72.

${ }^{17}$ Idem, p. 71.
} 
como "este meu corpo". Se nos perguntamos “que corpo?”, “de quem?", naturalmente chegamos à conclusão de que se trata do corpo de Takenaka Tokio, com uma sobreposição do autor onisciente seletivo múltiplo. Esse sumário demonstra bem esse tipo de narração e acrescenta, ainda, todo um erotismo na forma de expressão escolhida.

Ao final desse trecho, surge a fala: "Seja como for, a oportunidade se foi, ela já é de outra pessoa", ${ }^{19}$ e o romance continua com sumários até o final do primeiro capítulo, que se encerra com uma fala semelhante: "Não adianta mais, está tudo perdido!". 20

Essas falas nada mais são do que expressões verbalizadas da reação de Tokio diante do desenrolar dos acontecimentos que ele está rememorando.

O narrador de Futon segue o ponto de vista do protagonista. O que ele pensa e sente começa sendo introduzido com o pronome ou o nome dele, mas logo temos a impressão de que o próprio protagonista assumiu a narração. O narrador fica limitado em relação às demais personagens, o que pode ser percebido por expressões atenuantes, como "rashii" e "sō", ao comentar sobre os pensamentos e sentimentos delas, quando não é possível inserir um diálogo para que elas mesmas possam se expressar ou, ainda, uma carta, à qual recorre muito para dar voz à Yoshiko. Por exemplo, as informações sobre as demais personagens chegam ao leitor como suposições ou impressões do narrador, que as transferem para a personagem. No dia seguinte à chegada do pai de Yoshiko, que viera para buscá-la, o narrador diz: "Yoshiko parecia ter dormido mal, pois na manhã seguinte estava pálida e sem fome" ${ }^{21}$. O narrador vê a moça pelos olhos de Tokio.

O discurso indireto livre também ajuda a identificação do pensamento do protagonista com o do narrador.

O nome do protagonista, até então identificado como "ele", só aparece a partir do segundo capítulo, que começa a narrar a história que teve início três anos

\footnotetext{
${ }^{18}$ Idem, p.71-2.

${ }^{19}$ Idem, p. 72.

${ }^{20}$ Idem, p. 73.

${ }^{21}$ Idem, p. 97.
} 
antes. A partir daí, a onisciência seletiva múltipla continua freqüente, como se pode notar por várias passagens, das quais destacamos:

Após o jantar, o pai retornou à hospedaria. Naquela noite, a angústia de Tokio foi imensa. A irritação era grande só de pensar que havia sido enganado. Ou melhor, ao perder o sentimento e o corpo de Yoshiko, ela por inteiro para um estudante, sentiu raiva de ter mantido a sua paixão com respeito e seriedade. Se fosse assim, se fosse para ela ter entregado o seu corpo àquele homem, nem precisaria ter respeitado a virtude de sua virgindade. Poderia ter aproveitado ao máximo e satisfeito sua vontade sexual. Ao pensar desse modo, viu a bela Yoshiko até então colocada num pedestal como uma prostituta e chegou a suspeitar do corpo dela e até mesmo de suas belas atitudes e expressões. Naquela noite, mortificou-se tanto que quase não dormiu. Vários sentimentos invadiram seu coração como uma nuvem negra. ${ }^{22}$

Na narração final da obra, que mostra a paixão e o desejo de Tokio por Yoshiko quando ela já partiu com o pai e o caso está definitivamente encerrado, predomina, no entanto, um sumário das ações e pensamentos do protagonista com mais clareza no uso do pronome pessoal "ele" ou do nome do protagonista Tokio, como se o narrador quisesse retomar a objetividade perdida e distanciar-se do protagonista. Por exemplo, depois de receber uma carta formal e respeitosa de agradecimento de Yoshiko citando o haikai de Issa - "Neve bem alta, / mais de metro e meio./ Enfim, é meu lar" - para descrever o percurso.

Tokio imaginou o longo caminho montanhoso sob a forte nevasca e a cidade interiorana no meio da montanha quase inteira sob a neve. Subiu ao andar superior que continuava igual depois da separação. Tamanha era a saudade e a paixão que pensara em reavivar as lembranças tênues que dela haviam restado. Era um dia frio com ventos fortes que sopravam de Musashino, e as árvores antigas do quintal faziam um barulho intenso como o da maré. Ao abrir a parte leste da janela de proteção contra a chuva como fizera no dia da separação os raios de luz invadiram o aposento. A escrivaninha, a estante de livros, o frasco, a vasilha de ruge, tudo estava igual. Era possivel pensar que a pessoa amada estaria, como sempre, na escola. Tokio abriu a gaveta da escrivaninha. Nela

${ }^{22}$ Ibidem. 
encontrou abandonado um laço de cabelo manchado de óleo. Tokio pegou-o e cheirou. Depois de algum tempo, levantou-se e abriu o armário. Três grandes baús de vime estavam prontos para serem despachados, e, ao lado, o acolchoado que Yoshiko usava. Embaixo, o de forrar com desenhos chineses de crisântemos e sobre ele, a veste noturna com enchimento espesso de algodão com a mesma estampa. Tokio tirou-os do armário. O cheiro de óleo e de suor da saudosa mulher fez o coração de Tokio palpitar de modo inexprimivel. Ele encostou o rosto no local mais sujo da gola de veludo da veste noturna e cheirou o quanto pôde o olor da saudosa mulher. Logo, o desejo, a tristeza e o desespero tomaram conta de Tokio. Tokio forrou aquele acolchoado, cobriu-se com a veste noturna e chorou com o rosto mergulhado na gola de veludo gelada e suja. O quarto estava meio escuro. Lá fora, o vento soprava violento. ${ }^{23}$

No início da obra, quase não há cenas com diálogos; elas aparecem mais do meio para o final da obra e desaparecem por completo no último capítulo.

O curto diálogo entre Tokio e Yoshiko na segunda oportunidade que lhe fora dada pela moça para abordá-la serve para imprimir o caráter de realidade e objetividade, para não dar margem a suspeitas de que o encontro a sós com a discípula na ausência da cunhada tivesse sido fruto de sua imaginação. No entanto, o discurso em si suscita dúvidas se ela realmente tinha interesse por ele e, isso sim, poderia ter sido um mero desejo acalentado que lhe pareceu real na fala e na atitude gentil da moça. O mesmo pode ser dito do que ele considerou como a primeira chance de confessar seu amor por ela. Yoshiko envia-lhe uma carta dizendo que não servia para ser sua discípula e não estava à altura de retribuir a gratidão que sentia por ele; assim, seria preferível voltar para o interior, virar esposa de um agricultor e ficar confinada em sua terra. Há, portanto, uma prova, mas não muito garantida, em termos de objetividade, de que ela queria chamar sua atenção, pois não aparece transcrita na íntegra como a que Yoshiko endereçara ao mestre pedindo desculpas por ter decidido, sem consultá-lo como deveria, buscar o namorado que a avisara de sua chegada, na última hora, por telegrama, e solicitando sua intervenção junto aos pais para que pudessem continuar com o namoro, e de outras que ela the enviou em diferentes ocasiões.

${ }^{23}$ Idem, p. 101. 
Em Shōjo Byō, cena e sumário se intercalam, mas a onisciência seletiva múltipla aparece em muitas passagens, que mostram os sentimentos, pensamentos e percepções do protagonista diretamente, das quais destacamos duas:

Como era bela expressão dos olhos da moça mais velha. As estrelas, as estrelas do céu, comparadas a ela perderiam o seu brilho, pensou. A barra de crepe de seda de cor chamativa de glicinia que descia bem esticada da região dos joelhos; seu tamanco de três camadas que deixavam as meias brancas com o calcanhar mais alto e principalmente ao imaginar que na região em que o peito estava claramente mais alto desde a parte final da gola branca ficavam seus lindos seios, sentia como se o corpo inteiro fosse tomado por um comichão. ${ }^{24}$

Ao fumar um cigarro entediado com a solidão daquele quarto meio escuro e triste, uma fumaça lilás paira ocupando uma grande extensão. Olhando-a fixamente, as imagens da moça de Yoyogi, das estudantes e da beleza de Yotsuya se misturam e se confundem, parecendo a figura de uma pessoa. Não deixa de pensar que é uma tolice, mas também não parece que é desagradável.

Depois das três, próximo ao horário de saída, pensa na casa, depois, na esposa. Que coisa mais sem graça! É muito triste ter envelhecido. De que adianta ter vivido a juventude sem se importar e agora se arrepender. Que coisa mais sem graça - repete. Por que não vivi uma paixão intensa quando jovem? Por que também não cheirei o suficiente o perfume da carne? De que adianta pensar nisso agora? Já tenho 37 anos. Ao pensar assim, tenho vontade de arrancar os cabelos de tanta irritação. ${ }^{25}$

Diferente dessas obras de Katai, Haru, de Shimazaki Tōson, que um ano depois confirmou a tendência apresentada por Futon, também é escrita em terceira pessoa, mas com um narrador onisciente neutro. A técnica bastante usada pelo narrador é mostrar o pensamento ou a fala das personagens em forma de citação. $\mathrm{O}$ ponto de vista da narração é objetivo. A descrição das personagens é acompanhada de verbos discendi e, quando se trata dos pensamentos e sentimentos da personagem descrita, o sujeito está bem marcado pelos pronomes pessoais ou pelo próprio nome da personagem em foco. Essa diferença extrema com Futon pode ser notada em Ie,

$\overline{24}$ Tradução nossa, Shōjo Byō, p. 68. 
também da autoria de Tōson. Ainda em Haru, merece destaque a técnica narrativa de despertar a curiosidade do leitor com a inserção de pequenos indícios ao longo do enredo que vão sendo desenvolvidos no desenrolar da história. Isso ocorre com as mulheres com as quais Kishimoto se envolve amorosamente, que ficam incógnitas para o leitor quando são mencionadas nas conversas com os amigos, ou com os indícios dos problemas de Aoki apresentados desde o início da narrativa, mas invisíveis aos amigos até que sejam revelados claramente.

Podemos dizer que as demais obras com narração em terceira pessoa não apresentam grandes novidades na narração, mas Kokyū Wasureubeki (Não se Deve Esquecer o Passado, 1935) é uma exceção.

Nessa obra, Takami Jun cria um narrador intruso que começa a obra fazendo um longo sumário inicial sobre Ozeki, o protagonista que precisa cortar o cabelo e finalmente resolve ir ao barbeiro. Lá, o narrador apresenta várias lembranças do passado do protagonista e em dado momento, interrompe a narração para retomar um assunto com um novo parágrafo referindo a si mesmo como "o escritor/este escritor":

$$
\text { [...] }
$$

Bem, o escritor desviou sem querer do assunto, e pediria ao leitor que mais uma vez entrasse no referido refeitório do alojamento estudantil. Em seu interior, várias mesas compridas enfileiram-se [... ${ }^{26}$

Mais adiante, começa a falar de Shinohara Tatsuya, que era bastante amigo de Ozeki, mesmo depois que foi para a faculdade, e continua com a intromissão depois dos parênteses usados para fazer a seguinte observação:

$$
\text { [...] }
$$

(normalmente, as amizades do colégio acabam sendo rompidas devido às diferentes escolhas das carreiras) e por ele ser uma personagem que em um capítulo posterior deste romance irá ter um pequeno desentendimento com Ozeki, prefiro omitir a apresentação de sua natureza e característica física, mas ele, pouco depois, deu o ar da graça de seu corpo comprido. Ao sentar-se [.... ${ }^{27}$

$\mathrm{E}$ a intromissão continua no parágrafo seguinte:

\footnotetext{
${ }^{25}$ Idem, p. 70.

26 Tradução nossa, Kokyū Wasureubeki, p. 32.

${ }^{27}$ Ibidem, p. 32-33.
} 


\section{$[\cdots]$}

Pensando bem, que desvio mais tolo o escritor acabou fazendo! Enquanto o escritor desperdiçou saliva, não é que o nosso protagonista Ozeki Kenji terminou há muito tempo o seu corte de cabelo e já voltou para a sua casa sem graça? Não tenho palavras de excusas ao leitor, pois isso também decorre unicamente da ignorância do escritor, pois acabei com delongas quando poderia ter resumido toda a falação anterior dizendo simplesmente que essa hesitação de Ozeki em entrar na barbearia, que foge um pouco dos padrões, não é causada, de maneira alguma, pela anormalidade fisica dele. Durante certo tempo, ele chegou a pensar que estaria doente, mas $[\ldots]^{28}$

E assim o autor prossegue a narração com interferências semelhantes, nas quais se dirige diretamente ao leitor ou dá explicações em parênteses, técnicas essas que lembram as empregadas por nosso célebre Machado de Assis.

Como autor engajado que foi obrigado pelo governo japonês a fazer a chamada "conversão", deixando de participar dos movimentos proletários e marxistas, Takami Jun, nessa obra, mostra a vida precária do protagonista assalariado de baixa renda que mora no subúrbio com a esposa e a mãe e que reencontra, no hospital em que vai fazer tratamento capilar, o amigo Shinohara, um ex-ativista que está bem de vida e é dono da revista Vogue. Por meio de longos flashbacks intercalados, narra as relações dos dois amigos e de outros companheiros que criaram uma associação de pesquisa socialista e editavam uma revista chamada Botsuraku Jidai - "Época de Decadência" - e as idéias que eles defendiam e as atividades que desenvolviam.

O recurso utilizado pelo autor é bastante inteligente, pois ele consegue tornar público o movimento marxista no Japão com personagens como seus ex-integrantes e, mantendo-se como narrador intruso, inserir observações como a de que

o fato narrado diz respeito à época, e que depois de tantos anos Shinohara e Tomonari dos dias atuais não mantêm mais os traços do passado, isso não é engano do escritor, mas culpa das inúmeras adversidades que sofreram. ${ }^{29}$

\footnotetext{
${ }^{28}$ Idem, p. 33.

${ }^{29}$ Idem, p. 85.
} 
Kabi, Aishiki Chichi e Giwaku ${ }^{30}$ foram escritas muito próximas umas das outras, mas enquanto as duas primeiras obras foram escritas na terceira pessoa do singular, com a diferença de que o protagonista da primeira tem o nome de Sasamura e o da segunda é identificado como kare, "ele"; a terceira obra tem a narração na primeira pessoa, com o uso de watakushi. Tanto em Kabi como em Aishiki Chichi predomina o elemento descritivo, e os sumários do narrador onisciente seletivo são centrados no ponto de vista do protagonista para mostrar seus sentimentos e pensamentos. A narração limita-se à descrição objetiva das ações e dos sentimentos dos protagonistas, Sasamura ou "ele", ou das personagens, como Ogin de Kabi. O mesmo ocorre na exposição do sonho que o protagonista de Aishiki Chichi tem com o filho, da carta da mãe e da resposta que o protagonista envia para a mãe, que aparecem na forma de sumários.

Em termos cronológicos, Giwaku é a obra que iniciou o uso do narradortestemunha com a primeira pessoa do singular watakushi, em 1913. Emprega um ponto de vista subjetivo, como a do narrador homodiegético, que foi seguido pelos Romances do Eu posteriores, como Kinosaki ni te, obra em primeira pessoa escrita por Shiga Naoya com base em uma história verídica do autor e que serviu para consolidar o gênero. Nela predomina o sumário, em que vamos acompanhando os pensamentos solitários e depressivos, mas ao mesmo tempo serenos e agradáveis, em meio ao clima outonal em que começa a narrativa, com o protagonista já nas termas. Ao encarar a morte como um fato inevitável e diante da incerteza de quando ela poderá ocorrer, constata que deveria haver alguma razão para ter sobrevivido ao acidente e estar, naquele momento, aguardando para saber seu futuro. Isso o leva a reflexões sobre sua situação a partir da observação de uma abelha já morta, de um rato diante da morte iminente e da morte de uma lagartixa d'água causada acidentalmente por ele.

Embora esse tipo de recurso narrativo criasse a impressão de maior proximidade do narrador-protagonista com o autor e devesse ter sido o escolhido

\footnotetext{
${ }^{30}$ Respectivamente Bolor, 1912, de Tokuda Shūsei, apontada por Nakamura Mitsuo como o típico Romance do Eu naturalista; Pai Digno de Compaixão, 1912, de Kasai Zenzō, considerado o mais representativo por Odagiri Hideo; e Suspeita, 1913, de Chikamatsu Shūkō, como a mais representativa, na opinião de Hirano Ken.
} 
pelos primeiros escritores para obras de cunho autobiográfico, só foi empregado muito depois, como comprova Giwaku, o que nos leva a seguir o caminho da confirmação de que, no início, as obras japonesas parodiaram as obras estrangeiras e, depois, dispensaram os modelos para seguir o caminho de uma consolidação como produto literário japonês. A partir de então, seguem as duas variantes de narração, na primeira e na terceira pessoa do singular, narração essa que se desenvolve no universo das diversidades possíveis.

Podemos destacar Sei Yohane Byōin, de Kanbayashi Akatsuki, entre as obras com narrador-testemunha que fogem ao padrão das anteriormente citadas. O autor brinca com o leitor, fazendo o narrador-protagonista relatar textualmente que conseguiu concluir sua décima obra literária enquanto a esposa está internada naquele hospital e que costuma ler as obras para ela. Mas, como suas obras versam sobre ela, constrange-se e lê apenas algumas partes. O narrador-protagonista vai mais longe ainda, dizendo que foi no quarto da esposa que escreveu o posfácio que integra essa obra, ou seja, a própria Sei Yohane Byōin, e que, a seu pedido, lê outro trecho transcrito na obra. $\mathrm{O}$ texto traz, ainda, um apêndice que esclarece que a mulher foi transferida em outubro para o terceiro hospital. Estava pele e osso, bem leve, mas melhor. Só não estava satisfeita com a transferência. No entanto, ele já estava desnutrido e não conseguia mais fazer o serviço de acompanhante. E a obra termina a caminho do referido hospital, com a esposa estranhando a respiração ofegante do cachorro, que ela pensa ser um cavalo que a está transportando na carroça. Esse tom humorístico final é ajudado pelo uso do boku para o narrador-protagonista, que cria maior proximidade com o leitor e ameniza a situação trágica desse casal, que vive a doença e a pobreza em tempos de guerra.

\section{Vida pessoal, representação literária, verossimilhança}


Em A Arte da Ficção, Henry James diz: “A única razão para a existência de um romance é a de que ele tenta de fato representar a vida",31. O Romance do Eu compartilha desse pensamento, na medida em que é verossímil e também baseado numa vivência, numa experiência real, continuando, contudo, a ser uma representação da realidade e dos fatos. Mas o principal esteio nos comentários sobre as obras do Romance do Eu é justamente sua identidade com a vivência do autor.

Segundo as próprias declarações de Katai, Futon partiu da idéia de revelar sua paixão recente por uma jovem discípula, mesmo arriscando sua reputação de homem casado e com filhos e preocupando-se com a reação da moça, que na época já havia retornado para a casa dos pais, no interior. Ele tomou a decisão de escrever a obra já pronto para desistir desse amor. ${ }^{32}$

Trata-se da jovem discípula Okada Michiyo, nascida em 10 de abril de 1885, com quem inicia a troca de correspondência a partir de julho de 1903. No final de fevereiro de 1904, a moça é trazida pelo pai Kanjirō (fundador do banco Jōge, da Província de Hiroshima) e, desde então, passa a morar no andar superior da casa de Katai e freqüenta o curso na instituição de ensino conhecida como Tsuda Juku. Em março, Michiyo vai para a casa de Asai, irmã mais velha da esposa de Katai, que mora em Kōjimachi Dote, 3 banchō, exatamente como está na obra. No final de março, Katai vai para a guerra e retorna em março do ano seguinte. Em setembro de 1905, novamente hospeda Okada Michiyo em sua casa, em função da vinda de Eidai Shizuo, o namorado dela, a Tóquio. Em janeiro de 1906, envia a moça de volta para casa e em setembro do mesmo ano visita a discípula quando está em viagem pela região. Os estudiosos japoneses afirmam também que essas pessoas são o protótipo das personagens de Futon.

Pelas notas que acompanham a edição publicada na coleção Nihon no Bungaku, em Haru, o protagonista Kishimoto Sutekichi é o próprio Shimazaki Tōson, que em outubro de 1892 tem um caso com Satō Sukeko, sua aluna, protótipo

\footnotetext{
${ }^{31}$ Henry JAMES, A Arte da Ficção, p. 21.

${ }^{32}$ No $47^{\circ}$ dia de falecimento de Katai, ocorrido em 9 de junho de 1930, Maeda Noboru comentou que essa obra foi resultado da proposta recebida pelo autor da revista Shinshōsetsu logo depois de ter retornado da guerra contra a Rússia. Katai viu nela a oportunidade de retomar as atividades de escritor ao lado de seus colegas já consagrados literariamente, como Doppo e Tōson. Kaidai (Esclarecimento). Trinta Anos de Tóquio (Tóquio Sanjūnen). In: Katai TAYAMA,. Futon; Ippeisotu. 107-10.
} 
de Katsuko na obra, motivo pelo qual Tōson pediu demissão, em janeiro de 1983, e saiu em viagem a Kansai e Shikoku. Esse fato consta da obra, que tem início com o retorno de Kishimoto dessa viagem. Praticamente todos os amigos do protagonista têm um protótipo correspondente na vida real. Kitamura Tōgoku (1868-1894), crítico que mais influenciou Tōson, é o protótipo de Aoki Shun'ichi; Ishizaka Mina, de Misao; Hirata Tokuboku (1873-1943), companheiro da revista Bungakugai, na época estudante do colégio Daiichi Kōtōgakkō, que ficou conhecido como tradutor de literatura inglesa e ensaísta, é o protótipo de Ichikawa Senta; Togawa Akibone (1870-1939), companheiro da Bungakukai e tradutor de literatura inglesa e ensaísta, de Suge Saburō; Hoshino Tenchi (1862-1950), patrocinador da revista e colega da Universidade Meijigakuin; de Okami (o mais velho); Hoshino Yūkei, de Okami Seinosuke (mais novo); Baba Kochō (1869-1940), companheiro da revista Bungakukai e colega da Universidade Meijigakuin, de Adachi Yumio. Ueda Bin (1874-1916), companheiro da Bungakukai, assumiu a posição de líder da revista após a morte de Kitamura Tōgoku; Higuchi Ichiyō (1872-1892), escritora representativa, era amiga de Kochō e Akibone e teve a obra Takekurabe publicada na Bungakukai. Togawa Zanka (1855-1924), membro convidado da revista Bungakukai, poeta, historiógrafo e divulgador do cristianismo, é o protótipo de Suge Chiharu.

Assim, para os críticos, as personagens, desse modo, nada mais são que pessoas reais trazidas para a obra com nomes alterados. O Romance do Eu segue com a sina de ser visto como simples registro da vida do autor, o que se pode observar pelas palavras de Yamamoto Kenkichi, que afirma que Shimazaki Tōson foi o único na historia do Romance do Eu, que já tem meio século, a pôr em prática as palavras de Itō Sei (que Yamamoto afirma terem sido escritas na explicação sobre Sei Yohane Byōin): "as obras são curtas, mas lendo-as como continuidade, trata-se de uma longa narrativa sobre a vida de um escritor, de um pensador" - não em seqüência cronológica, desde o nascimento até a velhice, pois escreveu Oitachi no Ki depois de Haru e Ie. Ele afirma ainda que Kanbayashi Akatsuki é o típico romancista do Eu, muito mais do que Tonomura Shigeru e Ozaki Kazuo ${ }^{33}$.

\footnotetext{
${ }^{33}$ Kenkichi YAMAMOTO, Gendai Nihon Bungaku Zenshū, Takii, Tonomura, Ozaki e Kanbayashi Shī, p. 401.
} 
Ie passa por explicações semelhantes relativas às personagens e aos protótipos da vida real, trazendo uma árvore genealógica elaborada pelo estudioso Nakano Yoshio ${ }^{34}$ para identificar as famílias Koizumi, Hashimoto e seus membros com os protótipos dos membros da famílias Shimazaki e Takase.

De modo semelhante, sabe-se que Giwaku e Kurokami, de Chikamatsu Shūkō, ambas narradas em primeira pessoa, relatam episódios da vida do autor por informações externas ao texto e também pela abordagem do mesmo conteúdo em outras obras que precederam Giwaku, como Wakareta Tsuma ni Okuritaru Tegami (Carta Enviada à Minha Ex-esposa) e Zoku Wakareta Tsuma ni Okuritaru Tegami (Carta Enviada à Minha Ex-esposa-Continuação).

É muito conhecido, também, o fato de que Kinosaki ni te foi escrito em 1917 por Shiga Naoya com base em uma história verídica pessoal, quando ainda tinha dúvidas quanto a seu restabelecimento de um acidente de trem sofrido três anos antes. Com uma narrativa curta em primeira pessoa identificada apenas como jibun, ou seja, "eu" ou "eu mesmo", Kinosaki ni te apresenta, de modo concreto, informações reconhecíveis como parte da vida do autor Shiga Naoya, que é a autoria real de uma obra literária mencionada textualmente, mas mesmo assim sem uma auto-apresentação do narrador-protagonista como autor. Além do próprio enredo, criado a partir da experiência do autor, encontramos em Kinosaki ni te outros dados ligados à realidade de sua vida: o cemitério de Aoyama, em Tóquio, onde fica o jazigo da família Shiga. Na ocasião, ele diz pensar muito sobre o ferimento:

Se algo tivesse saído errado, a essa altura estaria sob o solo de Aoyama de barriga para cima. Com a cara pálida, gelada e dura, com os ferimentos no rosto e também nas costas. Os restos mortais de meu avô e minha mãe ao meu lado. Mas agora, sem qualquer relação entre mim e eles. Tais são as coisas que me vêm à mente. ${ }^{35}$

Han no Hanzai (O Crime de Han), escrito um pouco antes dessa obra, e $A n^{\prime} y a$ Kōro (Trajetória em Noite Escura), romance no qual vinha trabalhando há muito tempo, também são mencionados:

\footnotetext{
${ }^{34}$ Yoshio, NAKANO, Kindai Nihon Bungaku Kan. Shimazaki Tōson I. p. 522.

${ }^{35}$ Tradução nossa, Kinosaki ni te, p. 109.
} 
Pouco tempo atrás, eu havia escrito um conto chamado Han no Hanzai. Era sobre um chinês chamado Han que assassina a esposa pelo ódio da relação que tivera com um amigo seu antes do casamento, e também por uma pressão fisiológica própria. Naquele conto, escrevi principalmente sobre os sentimento de Han, mas agora sentia vontade de escrever focalizando os sentimentos da esposa de Han e a sua quietude sob a sepultura depois de assassinada.

Pensei em escrever "Han ni Korasareta Tsuma" (A Esposa de Han Assassinada por Ele). Acabei não escrevendo, mas essa exigência tomava conta de mim. Fiquei sem ação, pois o sentimento dela era muito diferente daquele do protagonista do romance longo que eu já havia iniciado. ${ }^{36}$

Um fato interessante é que o autor utiliza os verbos no presente para relatar alguns fatos que se referem a Kinosaki. Por exemplo, no $1^{\circ}$ parágrafo usa vim no lugar de "fui" a Kinosaki, como se estivesse fazendo o relato no momento em que está no local, e traz algumas descrições, como a do telhado e da movimentação das abelhas, para o presente. O mesmo acontece com os fatos que mostra como se fossem atualizados no momento em que está escrevendo, ou seja, três anos depois, como se pode ver no $2^{\circ}$ parágrafo: Atama wa mada nandaka hakkiri shinai. (Minha cabeça/mente continua confusa.) Ou no na $6^{\text {a }}$ linha do $3^{\circ}$ parágrafo: Shikashi sore niwa shizuka na ii kimochi ga aru. (Mas nisso tudo, encontro uma sensação serena e agradável.)

Para o Romance do $\mathrm{Eu}$, a recepção foi um elemento importante na história da literatura japonesa, pois os autores aproveitaram-se do interesse que o público tinha pela vida dos artistas e exploraram a emoção que a obra poderia proporcionar, buscando uma identificação do escritor com o protagonista, principalmente nos aspectos que deveriam ser mantidos em segredo, como é o caso da paixão amoral de Takenaka Tokio, da humilhação sofrida pelo protagonista de Giwaku, que procura pela mulher que o traiu, ou mesmo da situação deprimente do protagonista de Aishiki Chichi, que se preocupa com sua reputação diante do filho.

Como foi visto, entretanto, a relação entre a obra e a vida do autor é fabricada por elementos externos, e no nível formal, as obras não permitem nenhuma

\footnotetext{
${ }^{36}$ Idem, p. 111-112. Han no Hanzai foi escrita em 1913, e An'ya Kōro foi iniciada em 1912 e concluída em 1937.
} 
identificação precisa entre as personagens e seus protótipos tirados da vida real. Algumas, como a obra Koi, de Ibuse Masuji, e Fugaku Hyakkei, de Dazai Osamu, apresentam elementos diferenciados, como a inserção do protótipo com seu próprio nome na vida real, ou seja, uma personagem que tem o nome de uma pessoa que fez parte da vida real do autor e foi utilizada como protótipo dessa personagem.

É o caso de Aoki Nanpachi, em Koi, e de Ibuse Masuji, em Fugaku Hyakkei, ambos escritores japoneses contemporâneos dos autores das respectivas obras.

Na obra, Aoki é o amigo que deu a carpa ao protagonista em Koi e que traz, ao lado de seu nome, a informação entre parênteses de que faleceu no ano anterior. Aoki Nanpachi, o protótipo dessa personagem que tem o mesmo nome que ele, é o amigo de Ibuse Masuji, o autor, que no início da carreira literária submete a sua apreciação as obras que escreve utilizando animais. Falece pouco depois, em 1922. Koi foi publicada em 1926, na revista Zuihitsu Zasshi, e em 1928 na revista Mita Bungaku, mas foi escrita no ano seguinte ao falecimento de Aoki Nanpachi, de quem Ibuse se tornou amigo íntimo no primeiro ano em que cursava a Universidade Waseda, em 1919. A utilização do nome real desse amigo do autor, que na obra exerce o mesmo papel, de amigo do protagonista, possibilita uma aproximação do autor e protagonista, mas mesmo assim sem uma identificação precisa dada no próprio texto. Na vida real, a amizade do autor e de Aoki durou quatro anos, segundo mostra a cronologia do autor, mas conforme consta na primeira frase da obra a carpa que ganhara do amigo é uma preocupação de mais de dez anos. Vemos, então, que na elaboração o que prevaleceu foi a idéia de mostrar que a amizade entre eles é muito mais longa e, por isso, aumentada, como para justificar o enaltecimento do protagonista pelo amigo.

Em Fugaku Hyakkei, a personagem Ibuse Masuji é o escritor que apadrinha o casamento do narrador-protagonista com uma moça da cidade de Kōfu. O protagonista chega à hospedaria em Misaka Tōge, em 13 de setembro de 1938, para ir ao encontro de Ibuse, que já estava lá há mais tempo. Na vida real, o eminente escritor Ibuse foi mestre e padrinho de casamento de Dazai Osamu, o autor dessa obra, conhecida como um registro relacionado a sua união com Ishihara Michiko. Segundo a cronologia de Dazai, ele conheceu a moça em 19 de setembro, quando ela 
tinha 26 anos e ele, 29. O noivado ocorreu em 6 de novembro e o casamento, em 8 de janeiro de 1939. Na obra, no entanto, a data em que o protagonista conhece a moça, em Kōfu, consta apenas como "dias" depois de sua chegada, e a data do noivado e do casamento nem são mencionadas.

Tsushima só pode ser identificado com o autor pelo leitor que conhece sua história, pois ela não apresenta nenhum registro que torne possível sua identificação e somente afirmações ${ }^{37}$ como as de Aono, ${ }^{38}$ segundo quem é um Romance do Eu de Tokuda Shūsei, um modelo do romance introspectivo, no qual a descrição é tensa e as nuanças delicadas de seu estado de espírito estão extremamente condensadas e tornam possível a classificação dessa obra como Romance do Eu.

Informações no texto acerca do protagonista e que remetem a um conteúdo extraliterário da obra, que faz parte da vida do próprio autor, são encontradas em obras como Kinosaki ni te, Koi, Fugaku Hyakkei e Sei Yohane Byōin ni te. Embora ainda seja necessário ter o conhecimento do fato real para identificar o conteúdo da obra como parte da vida do escritor, a existência desse seu elo registrado conscientemente na hora da elaboração mostra sua intenção de deixar uma marca da vida real, detectável a quem interessar, mas ainda assim sem revelar sua autoria de modo concreto.

Como ficou evidente, no entanto, nem as obras com foco narrativo em terceira pessoa nem aquelas em primeira pessoa do Romance do Eu trazem uma fórmula semelhante à do pacto autobiográfico de Philipe Lejeune, que identifica autor $=$ narrador $=$ protagonista, como é o caso de As Confissões, de Rousseau, que traz a identificação do narrador com nome e assinatura, ou do narrador de Baú de Ossos, que dá a data de nascimento e a filiação de Pedro Nava, seu autor.

\footnotetext{
${ }^{37}$ Wada Yoshie, ao escrever Na época de Bolor (publicado no Geppō, n. 26 de fevereiro de 1955 do Gendai Nihon Bungaku Zensh̄u), comenta que na época em que a obra foi publicada, quando tinha 42 anos, o escritor e sua esposa estiveram presentes à cerimônia de casamento de Mishima Shimokawa, personagem identificada como Miyama e depois como M, na edição de bolso. Em dado momento, Shūsei agrediu a esposa na presença de várias pessoas porque achou que ela estivera mostrando intimidade demais com Ayabe, repórter da revista Taiyo e padrinho de Mishima, embora nenhum dos presentes tivesse achado nada de íntimo no comportamento dos dois. E ela vê esse fato da vida retratado em Bolor e em Rastros, anos mais tarde, comentando que é uma obra representativa do Naturalismo, criada à custa do sofrimento de alguém.

${ }^{38}$ Shūkichi AONO, Gendai Nihon Bungaku Zenshū 10 Tokuda Shūsei shū, p.422.
} 
No Romance do Eu, a identificação autor $=$ narrador $=$ protagonista se faz tão-somente pela autoria do livro, ou seja, o nome que a obra traz assinado é sua única garantia - se é que assim pode ser considerada - mas frágil, inconsistente. O autor não assume textualmente a identidade do narrador quando a obra é escrita em primeira pessoa, nem a identidade do protagonista quando traz o foco narrativo em terceira pessoa. A obra é elaborada como ficção e, embora se diga que foi criada em cima do pressuposto de que o leitor conhece ou reconhece o enredo como parte da vida do autor, um episódio narrado em fato verídico, o pacto no estilo de Lejeune não existe no texto. Se é que tal pacto é possível, ele acontece na esfera extraliterária entre o autor e o leitor, ou entre o crítico e o leitor, o que poderia significar que o Romance do Eu só é viável dentro de um contexto limitado e definido que precisa ser complementado por informações extras acerca da biografia do autor. A obra sozinha não possibilita a um leitor lê-la como uma obra que expõe um fato verídico da vida do próprio autor, a não ser que ele disponha de informações sobre a história da formação do Romance do Eu e do jogo de criação e recepção dessas obras, que inicialmente estiveram circunscritas aos círculos literários japoneses, com suas revistas formadas por pequenos grupos de literatos, e tente fazer associações e comparações.

Embora tenhamos conseguido observar que as obras estudadas do Romance do $\mathrm{Eu}$ possuem uma verossimilhança interna, entendemos que, para os críticos literários japoneses, o Romance do Eu cria sua verossimilhança fundamentando a obra numa suposta verdade sobre a vida do autor. Entretanto, as obras são uma representação da realidade e possuem sua própria autonomia, como foi demonstrado, em especial no tocante às personagens e ao foco narrativo, que mostram que "o autor primário (não criado) - natura non creata quae creat" secundário (imagem de autor, criada pelo autor primário) - natura creata quae creat" $"$ - nem "imagem da personagem - natura creata quae non creat" ${ }^{41}$, como diz Bakhtin:

\footnotetext{
${ }^{39}$ Natureza não criada que cria. Mikhail BAKHTIN, Estética da Criação Verbal, p.400.

${ }^{40}$ Natureza criada que cria. Ibidem.

${ }^{41}$ Natureza criada que não cria. Idem, 384.
} 
O autor de uma obra só está presente no todo da obra, não se encontra em nenhum elemento desse todo e menos ainda no conteúdo separado do todo. $O$ autor se encontra naquele momento inseparável em que o conteúdo e a forma se fundem intimamente, e é na forma onde mais percebemos a sua presença. A crítica costuma procurá-lo no conteúdo destacado do todo, que permite identificá-lo facilmente com o autor-homem de uma determinada época, que tem uma determinada biografia e uma determinada visão de mundo. Aí a imagem do autor quase se funde com a imagem do homem real.

O verdadeiro autor não pode tornar-se imagem, pois é o criador de toda imagem, de todo o sistema de imagens da obra. É por esta razão que a chamada imagem de autor não pode ser uma das imagens de dada obra (é verdade que é uma imagem de tipo especial). [...] O autor-criador não pode ser criado na esfera em que ele próprio é o criador. Trata-se da natura naturans ${ }^{* 2}$ e não da natura naturata. ${ }^{* * 43}$ Vemos o criador apenas em sua criação, nunca fora dela. ${ }^{44}$ ().

\section{A presença do velho e do novo}

Nas obras, o Japão moderno está em vias de integração com o Ocidente. A atmosfera da época de grande contato com o que é ocidental se faz presente de diversas maneiras. A sala de trabalho de Takenaka Tokio fica numa fábrica em estilo ocidental, aludindo à industrialização japonesa nesse período. Há várias obras ocidentais que servem como referência para o pensamento e o sentimento dos protagonistas, demonstrando uma intenção clara de criar uma intertextualidade com a obra. Em Futon, Fausto, de Turguéniev, foi ensinada a Yoshiko, mas ele nem chegou a indicar Einseme Meschen, drama lido também três anos antes, antes mesmo de conhecê-la e considerá-la sua Anna Mahr e não poder ser o Johannes dessa obra de Hauptmann. Na Véspera, de Turguéniev, é a obra mencionada como estudada por Yoshiko quando Tokio se faz passar por mestre, zelando pelo namoro dela com o rapaz.

\footnotetext{
${ }^{42}$ Natureza geradora.(N. da ed. port.)

${ }^{43}$ Natureza gerada. (N. da ed. port.)

${ }^{44}$ Mikhail BAKHTIN, Estética da Criação Verbal, p. 399-400.
} 
Yoshiko compra livros de Turguéniev, e em sua estante vemos as obras completas de Ozaki Kōyō Ozaki, Sewa Jôruri, de Chikamatsu Monzaemon e livros didáticos de inglês.

Tokio tomava Magda de Sudermann, Nora de Ibsen e Helene de Turguéniev, moças cheias de vontade e sentimento, como modelos para dizer a Yoshiko que ela precisa ser moderna e livre, mas ter consciência e não ser dependente como as mulheres que saem da casa do pai para a casa do marido. Achou-se como o "homem supérfluo" ${ }^{45}$ de Turguéniev quando vira um beberrão, totalmente impaciente, que desiste até de reclamar da esposa e fica totalmente alterado. Tem acessos de ternura e de violência, sem noção do que faz, pois chega a cair e dormir no chão do banheiro enrolado num edredom. Antes, incapaz de perder a razão, arrepende-se por ser dominado por essa natureza. Sofre, mas as pessoas vêem-no como pessoa íntegra e digna de confiança, gerando um conflito interior.

$\mathrm{Na}$ Véspera, de Turguéniev, que foi programação diária dos estudos de Yoshiko, faz com que ela se identifique com a história de amor de Hèlene e de seu fim triste. Quando reflete sobre sua triste relação com a esposa, temos sobre a mesa a obra de Maupassant Fort comme la mort, e ele se lembra de Le père, do mesmo autor, que conta que uma jovem se entrega e depois chora quando pensa no que aconteceria se revelasse sua paixão.

No final da obra, enquanto aguarda a partida de Yoshiko, recorda-se de Púnin e Babúrin, de Turguéniev, que ensinara a Yoshiko, e o sentido da vida descrito por esse grande escritor russo toca seu coração.

Ao mesmo tempo em que há uma introdução massiva dessas obras estrangeiras, as obras japonesas não deixam de fazer parte do cenário. $\mathrm{O}$ autor usa $\mathrm{o}$ haicai de Kobayashi Issa para descrever a paisagem da neve mencionada por Yoshiko na carta que envia depois de chegar em sua terra. Também é citado textualmente que Yoshiko, no internato feminino de Kobe, chegara a ler romances

\footnotetext{
45 Protagonistas da literatura russa como Stavróguin, de Os Demônios, de Dostoiévski, descrito como "egoísta" consciente e "pessoa ociosa"; "homem enfastiado"; que "estava na moda"; "olha com zombaria e ceticismo"; "cétilo e Don Juan, mas só que desolado" e "personagem enigmática e romântica. Cf. Os Arquétipos Literários, p. 242-3.
} 
proibidos pelo Ministério da Educação, como Makaze Koikaze ${ }^{46}$ (Vento Feiticeiro, Vento da Paixão, 1903, no Yomiuri), de Kosugi Tengai, e Konjiki Yasha ${ }^{47}$ (Monstro Dourado, 1898, no Yomiuri/1903, continuação no Shinshōsetsu), de Kōda Rohan; e dessa maneira traz a personagem para um plano próximo à situação do leitor da época.

A modernidade e as mudanças que se processam no Japão não estão restritas a Tóquio como grande capital e centro dos acontecimentos. Yoshiko é natural de Niimi-machi, "Cidade Nova", mostrando que ela deve ser diferente da geração passada. Kobe, a oeste do Japão, e a cidade interiorana de Yoshiko também respiram as novas influências, e nesse aspecto podemos ver que não há uma oposição entre cidade e interior.

Já em Haru, as manifestações literárias anteriores à geração dos companheiros de Kishimoto são atacadas por eles. Enquanto bebem juntos, Aoki começa a atacar a febre Genroku, ou seja, a influência de Ihara Saikaku (1642-1693) manifestada nas obras dos escritores Ozaki Kōyō (1867-1903) e Kōda Rohan (18671947). Fala da necessidade da religião, não no sentido de seguir cerimônias e formalidades, mas de ter forte compaixão forte pela humanidade e ser crítico em relação à vida. Apesar das controvérsias, eram seguidores de Homero, Shakespeare e dos poetas Saigyō (1118-1190) e Matsuo Bashō. Todos foram antigos fiéis do cristianismo, e Ichikawa dizia que eles precisavam pensar em por que a literatura Genroku havia reaparecido. Eles tinham que destruí-la. Aoki exemplifica o que pensa citando Crime e Castigo, obra traduzida por Uchida. ${ }^{48}$

O grupo tem preferência pelos artistas estrangeiros, e Shakespeare e Byron são lidos e fazem parte dos assuntos discutidos pelos companheiros de Kishimoto. As obras estrangeiras não aparecem apenas mencionadas pelo título, como ocorre na maioria dos romances vistos, mas apresentadas por meio de textos originais e de sua tradução. Ao falar sobre Ofélia, Aoki começa a recitar aquele poema formoso,

\footnotetext{
${ }^{46}$ Tragédia amorosa da estudante Hagino Hatsuno e sua amiga Natsumoto Yoshie com seu noivo Natsumoto Togo.

${ }^{47}$ Hazama Kan'ichi torna-se agiota para se vingar de Miya e da sociedade com o poder do dinheiro, depois de ter a noiva, Shigisawa Miya, roubada por Tomiyama Tadao, que era rico.

${ }^{48}$ Uchida Roan, 1863-1929, crítico e romancista, aparece com o nome real.
} 
exibindo um lenço branco no lugar do buquê de flores. Vem a transcrição do poema no original que faz parte do canto de Ofélia, na Cena V do Ato IV de Hamlet: "How should I true love know/ From another one?/ By his cocke hat and ataff,/ And his sandal shoon. [...]", seguida pela tradução do poema com um parênteses no final, indicando como fonte Omokage, uma antologia de poemas traduzidos pelo grupo da Shinseisha centralizado em Mori Ōgai, publicado em 1889. Todos gostam e recitam junto.

O poema Child Harold, de Byron, também aparece no próprio original seguido da tradução em japonês, com parênteses indicando a tradução de Kanbara Ariake. ${ }^{49} \mathrm{O}$ trecho narra a ocasião em que Aoki vai com Kishimoto até a praia declamando o poema:

Roll on, thou deep and dark Ocean - roll!

Ten thousan fleets sweep over thee in vain;

Man marks the earth with ruin - his control

Stops with the shore; upon the watery plain

The wecks are all thy deed, nor doth remain

A shadow of man's ravage, save his own,

When, for a moment, like a drop of rain,

He sinks into thy depths with bubbling groan,

Without a grave, unknell'd, uncoffined, and unknown.

Em Kurokami, a personagem Koharu, da peça Amijima Shinju (Suicídio em Amijima), vem à lembrança do protagonista, juntamente com a descrição da paisagem noturna, quando está ao lado da mãe da gueixa que vai se casar com ele. Cumpre observar que a obra mostra o lado prisioneiro da vida das gueixas, que precisam comprar sua liberdade, como ocorre com as gueixas de País das Neves, de Kawabata Yasunari, ou resolver os problemas advindos de uma gravidez indesejada.

A presença do cristianismo no Japão moderno aparece de modo recorrente nas obras dessa época. Em Futon, os familiares de Yoshiko e o namorado freqüentam a Igreja de Kobe. Em Haru, Kishimoto e seus colegas da revista literária participam

\footnotetext{
${ }^{49}$ Kanbara Ariake (1876-1952) aparece com o nome real. Traduziu o poema especialmente para ser inserido em Haru.
} 
da igreja cristã, e o funeral de Aoki, ocorrido em 17 de maio, ${ }^{50}$ foi feito pelo pastor da igreja a pedido de Misao, mesmo com a família dele sendo de outro credo. O salmo entoado na ocasião é transcrito na íntegra.

É visível a oposição entre o antigo e o novo, as diferenças de época entre os jovens da época e de outrora e entre as mulheres da nova e da velha geração, mas também o entrelaçamento e a coexistência desses pares na vida dos japoneses.

Em termos de significado temático do cronotopo, o Romance do Eu tende para o enfoque da vida cotidiana individual do homem moderno em meio a suas insatisfações e temores. Segundo Bakhtin:

O tempo é o princípio condutor do cronotopo na literatura, na qual ocorre a fusão dos indícios espaciais e temporais, num todo compreensivo e concreto. Aqui o tempo condensa-se, comprime-se, torna-se artisticamente visivel: o próprio espaço intensifica-se, penetra no movimento do tempo, do enredo e da história. Os índices do tempo transparecem no espaço, e o espaço reveste-se de sentido e é medido com o tempo. Esse cruzamento de séries e a fusão de sinais caracterizam o cronotopo artístico. $^{51}$

Bakhtin entende o romance como prosa literária em constante formação e devir que supera as limitações canônicas dos gêneros. $\mathrm{Na}$ "Arte e Responsabilidade"52 identificamos ressonâncias com os Romances do Eu, e especialmente nos cronotopos bakhtinianos encontramos a razão da existência dessas produções literárias japonesas que começam a surgir com a introdução de novas tendências e conceitos tão logo ocorre a abertura do país para o Ocidente, já que o estudioso russo entende que o texto literário dialoga com seu contexto social.

O protagonista do Romance do Eu vive um drama interior; a trama acontece no nível do embate entre o sentimento e a razão que vão se manifestar em determinadas atitudes e comportamento dentro da narrativa. Normalmente, a solução para o conflito interior é a resignação que se reverte em aceitação da condição que lhe é imposta pela situação. Nesse aspecto, é interessante apresentar a visão de Stam

\footnotetext{
${ }^{50}$ Tōgoku morreu em 16 de maio de 1894.

${ }_{51}^{51}$ Mikhail BAKHTIN, Questões de Literatura e de Estética, p. 211.

52 Mais precisamente em "O autor e a personagem na atividade estética" em Estética da Criação Verbal.
} 
de que o discurso é produzido dentro de um contexto social, "engloba o textual, o intertextual e o contextual",53.

Mais do que refletir uma situação pró-textual, o discurso é uma situação pró-textual, o discurso é uma situação. A elocução artística é uma interlocução, um meio-termo entre o texto e um leitor cuja compreensão receptiva é buscada e antecipada, e de quem o texto depende para sua concretização. Tanto Bakhtin como a teoria da recepção resistem ao isolamento formalista do texto; eles postulam leitores reais, ativos, com a diferença de que Bakhtin dá uma densidade social mais especifica dos leitores "virtuais", "implicitos" e "ideais" da teoria da recepção, munindo-os de um endereço concreto, um nome, um gênero, uma classe, uma nação. ${ }^{54}$

Além disso, é outra "vantagem das categorias conceituais de Bakhtin, identificação com a diferença e a alteridade, sua afinidade intrínseca com tudo o que é marginal e excluído" 55 . O estudioso esclarece que "Bakhtin passou a associar arte com espaço aberto, com liberdade, com alternativas utópicas para a cultura oficial" ${ }^{, 56}$, e isso tem muito a ver com o Romance do Eu. Stam diz que, "na relação entre eu e outro, Bakhtin argumenta que cada um de nós ocupa um lugar e um tempo específicos no mundo e que cada um de nós é responsável, ou 'respondível' por nossas atividades". ${ }^{57}$ E continua: "O que vemos é determinado pelo lugar de onde vemos. Diálogo - necessidade e produtiva complementaridade de visões, compreensões e sensibilizações. O eu se constrói em colaboração. A palavra é sempre ideologia por natureza. Segundo Bakhtin: a literatura não pode ser compreendida fora do contexto global da cultura de uma determinada época". ${ }^{58}$ Stam afirma, ainda, que é "só através dos olhos de uma outra cultura que uma cultura estrangeira se revela da maneira mais completa e profunda". 59

O estudioso Ueda Makoko afirmou que a obra de Katai chamou a atenção por expor abertamente a sexualidade, um tema novo, inexplorado. Contudo, antes do

\footnotetext{
${ }^{53}$ Roberto STAM, Bakhtin, da Teoria Literária à Cultura de Massa, p.13.

54 Ibidem.

55 Idem, p. 14.

56 Idem, p. 16.

${ }^{57}$ Idem, p. 17.

${ }^{58}$ Idem, p. 75.

${ }^{59}$ Idem, p. 78.
} 
contato do Japão com as correntes literárias ocidentais, a prosa japonesa já se via às voltas com o mesmo tema, como é o caso de Kōshoku Ichidai Otoko (Um Homem que se Deu ao Amor), do século XVII. Nessa obra é exposta a vida erótica de Yonosuke, filho de um rico comerciante e de uma prostituta, desde os 7 até os 60 anos, parodiando a obra Genji Monogatari (Narrativa de Genji) ${ }^{60}$ do século XI.

No que diz respeito à questão da sexualidade abordada nas obras literárias, nota-se, como já foi dito, um peso maior da influência do cristianismo ${ }^{61}$ em sua corrente protestante introduzida nesse período, uma vez que ela foi alvo do interesse de intelectuais e da classe dominante, e grande número de escritores e poetas conheceu a fé cristã. Uns receberam o batismo, outros foram apenas simpatizantes em algum momento de suas vidas, mas, com exceção de pregadores como Uchimura Kanzō e de fiéis como Arishima Takeo, a maioria acabou por abandoná-la. É natural que os princípios que regeram o comportamento dos japoneses durante séculos não fossem abandonados da noite para o dia. O protestantismo ia de encontro a outros "ismos" enraizados na cultura japonesa, como o confucionismo, o budismo e o xintoísmo. Feito a religião oficial do país nessa época, o xintoísmo prestou-se mais a levar o povo à obediência incondicional ao Imperador e aos governantes.

Fruto de um conflito interior que beira a contradição do novo e dos velhos "ismos", o intelectual cristão japonês precisava se converter (de modo radical) ou tornar-se simpatizante apenas de parte de seus ensinamentos. Esse conflito é o que pode ser constatado na atitude do protagonista de Futon.

$K a b i$, de Tokuda Shūsei, obra também do período inicial do gênero, apresenta traços diferentes da obra de Katai e incita a curiosidade para um universo de possibilidades diversas. O protagonista envolve-se com a filha de uma "empregada", mas aquela não é nem a bela virgem nem inatingível. Dessa relação nasce o primeiro filho do casal, que ora se desejou abortar, ora abandonar, dando-o para ser criado por alguma família. O que faz que duas obras como essas, narradas respectivamente em terceira pessoa e em primeira pessoa, fiquem lado a lado numa única denominação Romance do Eu?

\footnotetext{
${ }^{60}$ Escrita pela dama da corte Murasaki Shikibu em 1001. V. Apêndice p.
} 
Pode-se constatar que essas duas obras apresentam influências do cristianismo ao defender a família e o sistema monogâmico. O protagonista de Futon não sofreria com tal conflito se não conhecesse esse princípio cristão e o código civil não tivesse alterado os hábitos nipônicos, pois os japoneses foram poligâmicos desde sempre, até a abertura para o Ocidente. O mesmo pode-se dizer do jovem Sasamura, que queria se desvencilhar de Ogin e do filho que teve com ela, mas acaba sendo persuadido, obrigado a ficar com ambos. O cristianismo também começa a fazer parte dos rituais do cotidiano dos japoneses, como podemos ver pelo funeral de Aoki, realizado pelo ritual cristão.

O cristianismo continuou a ser divulgado, chegando a ter hospitais como o São João, em que a esposa cega do protagonista de Sei Yohane Byōin ni te ficou internada. Mesmo assim, os tradicionais conceitos confucionistas de giri - "dever" e de ninjō - "sentimento humano" -, e de honne - "sentimento verdadeiro" - e de tatemae - "manutenção da aparência" - são mantidos na vida dessas personagens, acrescidos dos novos elementos da moral cristã que penetram de tal maneira que eles não são capazes de ir contra os novos preceitos e agir conforme seus sentimentos autênticos. É possível ver, nessas atitudes, os princípios de awase - "junção" - e kasane - "sobreposição", "combinação" - apresentados por Matsuoka Seigo ${ }^{62}$, como ocorreu com o kami, divindades japonesas, e com Buda, no Japão.

Ligados a esses dois últimos conceitos, podemos, ainda pensar em outros fatores que levam os escritores e prosadores japoneses a centrar tanto seus enredos em suas experiências pessoais. Como homens representantes de uma época, suas vidas são facetas da vida do povo que vive um mesmo contexto histórico-social, no caso um momento de grande repressão e de censura ideológica. A liberdade de expressão não existe. Militantes e religiosos são os principais alvos das perseguições, mas a censura japonesa está atenta aos escritores e intelectuais, que têm plena ciência disso. Portanto, usam o tatemae para mostrar o honne. É nesse sentido que Shiga

\footnotetext{
${ }^{61}$ A igreja católica foi introduzida pela companhia de Jesus, que chegou ao sul do Japão no século XVI e formou um grande número de fiéis, mas foi banida com o isolamento do país.

${ }^{62}$ Seigo MATSUOKA, NHK Ningen Kōza - Omokage no Kuni, Utsuroi no Kuni, Nihon no Henshū Bunka o Kangaeru (Curso Ser Humano - País dos Vestígios, País das Transposições - Reflexões sobre a Cultura da Edição do Japão, TV NHK).
} 
Naoya, considerado o "deus do romance", nunca deixou de escrever e de vender suas obras. Era divino em saber o que e como escrever. E os demais escritores também lançaram mão desse recurso cada qual, utilizando-se de seus próprios recursos. Dazai Osamu, por sua vez, cria uma obra inusitada com Pôr-do-sol, escrita em 1947, como veremos no capítulo seguinte. 


\section{CAPÍTULO III}

\section{PÔR-DO-SOL, ${ }^{1}$ DE DAZAI OSAMU}

— para além dos horizontes do Romance do Eu.

Pôr-do-Sol (Shayō) foi escrito por Dazai Osamu em 1946. Após o final da Segunda Guerra Mundial, Kazuko, a narradora-protagonista, e sua mãe, ${ }^{2}$ nobres arruinadas, são obrigadas a vender a mansão em Tóquio e morar em Izu, a cerca de $100 \mathrm{~km}$ da capital. Naoji, o irmão mais novo, é um literato iniciante que foi convocado para combater numa ilha do sul do Pacífico e volta recém-recuperado de sua dependência de ópio. Ele vive sem rumo, sempre fora de casa, às voltas com bebida e mulheres, acompanhando o escritor decadentista Uehara Jirō, por quem Kazuko foi cortejada no passado e por quem ainda nutre certa paixão. Ela decide ir atrás desse amor, mas adia o intento por causa da enfermidade da mãe, que adoece e morre logo depois da volta de Naoji. Kazuko, então, resolve seguir o destino que escolheu: ser amante de Uehara e ter um filho dele. Decepciona-se com a vida desregrada que ele leva, mas consegue engravidar e encontra a razão de viver lutando contra as convenções, à espera do filho.

Para estudiosos como Okuno Takeo, essas quatro personagens principais são desdobramentos do autor, e "As personagens dessa história são faces de Dazai: Naoji é a sua imagem da fase inicial, Uehara da fase final e Kazuko e a Mãe mostram o verso e o reverso da mentalidade da sua fase intermediária."3

Em Omoide (Recordações, 1933), a respeito do sofrimento causado pelo vazio que não conseguia preencher Dazai afirma: "Eu tinha dez ou vinte máscaras, e consegui arrumar uma válvula de escape que era a criação literária".

Pôr-do-Sol inicia focalizando a questão da nobreza japonesa, pois é seu declínio e sua extinção que a obra retrata por meio dessa família de nobres

\footnotetext{
${ }^{1}$ Título da obra em português, traduzido do original Shayō por Antonio Nojiri, em edição particular sem data.

${ }^{2}$ Utilizamos a maiúscula sempre que se tratar dessa personagem não nominada, exceto quando identificada em relação aos filhos, Naoji e Kazuko.

${ }^{3}$ Okuno TAKEO, Shinchō Nihon Bungaku 35, Dazai Osamu Shū, p. 648
} 
decadentes composta pela Mãe, Kazuko e Naoji, que são amparados por Wada, irmão da Mãe.

Na obra, a mãe de Kazuko é uma mulher que representa a nobreza decadente, mas uma nobreza nos moldes ocidentais. Essa família também é resultado de uma somatória de conseqüências histórico-sociais. Não pertence à nobreza tradicional, ligada por laços consangüíneos com a família imperial. São os novos-ricos que adquirem a posição pelo poder aquisitivo e passam a fazer parte da elite.

Kazuko e Naoji não se consideram nobres autênticos e sim Mendigos da Classe Alta, incapazes de imitar a Mãe, que é um modelo de nobreza e demonstra classe em tudo o que faz, até ao tomar a sopa de modo errado no final - virando a ponta da colher para colocá-la na boca -, segurar o frango com os dedos para comer ou urinar em pé, no meio dos arbustos e flores. Mas toda essa nobreza e classe assim são vistas como tais por Kazuko, que é filha, e não aos olhos da sociedade. "Sua maneira de tomar a refeição difere absolutamente das que vêm recomendadas nas revistas elegantes." (Cap. I) ${ }^{4}$

A língua japonesa apresenta uma natureza hierárquica bastante marcada e o autor se vale disso para brincar com as expressões. "Ilustríssimo mendigo da classe alta" corresponde, em japonês, a kōtō on kojiki. O prefixo on ${ }^{6}$ atribui o tratamento de respeito e consideração aos termos ligados a pessoas que se quer elevar ou valorizar, e no caso em questão seria equivalente a "Excelentíssimo, Ilustríssimo", normalmente com sentido valorativo, mas é usado justamente para kojiki -

\footnotetext{
${ }^{4}$ Todos os trechos citados da obra estudada neste capítulo foram extraídos de DAZAI, Osamu. Pôrdo-Sol. Trad. Antonio Nojiri. ed. particular, s.d. Assim, a citação será seguida apenas pela indicação do capitulo correspondente.

${ }^{5} \mathrm{Na}$ edição em língua portuguesa, Antonio Nojiri usa a expressão "Mendigos de Primeira Classe".

${ }^{6} \mathrm{O}$ que está aqui, em jogo, é a aparência. Não é a aparência, as atitudes e os modos da mãe que lhe dão a classe que ela tem inata, assim como não é o fraque ou o linguajar afetado usado pelos amigos condes e viscondes de Naoji, que exibem os títulos que demonstram sua nobreza. A Mãe é dotada de pureza de sentimentos. Quem é nobre de verdade não precisa usar de subterfúgios: "O nobre legítimo jamais se vale da desastrada afetação que vê num tipo como Iwajima".(Cap. I) Corresponde ao ideograma que, além de on, possui as leituras de $m i$, o e go, de mesmo sentido, mas usados de modo distinto; geralmente, on, $m i$ e $o$ para as palavras japonesas e go e gyo para as palavras de origem chinesa. Exemplos: ontoki (hora, momento), miyuki (saída, passeio de suas altezas reais), omizu (água), ohanashi (fala, pronunciamento), gohan (arroz cozido), goen (afinidade), gyohitsu (escrita ou caligrafia).
} 
"mendigo" -, que não pertence ao mesmo campo semântico e não receberia nenhum tratamento dessa natureza.

A obra começa em média res, num jantar com mãe e filha na casa em Izu, para onde acabaram de se mudar:

De manhã, na sala de jantar, mamãe sorveu uma colherada de sopa e soltou uma débil exclamação:

$-O h !$

- Cabelo? - perguntei, supondo tivesse encontrado algo desagradável. $-N \tilde{a}$.

A partir desse pequeno diálogo, é inserida toda uma reflexão da narradoraprotagonista sobre a questão da nobreza, rememorando as palavras do irmão, tecendo suas próprias considerações a respeito do assunto, mas tendo em mente o leitor que acompanha sua narração. Por isso, antes de retomar a narrativa no ponto em que parou, a narradora introduz a observação "Desviei-me bastante da conversa sobre a sopa desta manhã" e segue com mais um comentário sobre a nobreza da mãe, que reproduz os hábitos da época dos reis Luís franceses. É como se a narração interrompesse suas reflexões, e não o contrário.

$\mathrm{E}$, assim, voltamos à narrativa:

- Está salgada?

[...]

- Está muito bem feita.

Esse início é bastante elaborado. A descrição da mãe e filha, nobres decadentes, à mesa de jantar introduz a situação do Japão derrotado na Segunda Guerra Mundial. A sopa que a Mãe toma é de "conserva de ervilhas distribuída dias antes pelos americanos", numa alusão clara à ocupação norte-americana no pósguerra em nome da reconstrução e democratização do Japão. Sua exclamação ao tomar a primeira colherada vem da preocupação com o filho Naoji. Ele "fora convocado quando cursava a universidade e partira para as ilhas do sul". Mesmo com o término da guerra, ainda não tinham notícias dele. 
Outro “Oh!”, que Kazuko deixa escapar na seqüência do diálogo com a mãe, serve para atualizar a informação do leitor sobre o passado da narradoraprotagonista, divorciada há seis anos.

Kazuko mostra, logo nessas primeiras páginas, que se sente menosprezada pela mãe, que quer mais bem ao filho, apesar de ele ter sido motivo de constantes preocupações.

A cobra é o símbolo de mau agouro no Japão desde os tempos antigos. A inserção feita a respeito do incidente com as cobras no início da narrativa já era o prenúncio de morte. Elas estavam presentes em grande quantidade no jardim da casa quando o pai de Kazuko faleceu, dez anos antes, e quatro ou cinco dias antes do início da narrativa ela tentara queimar cerca de dez ovos de cobras achados pelas crianças da vizinhança. Elas pensaram que os ovos eram de uma serpente conhecida como mamushi, único espécime venenoso do Japão. Descoberto o engano pela filha de um agricultor, Kazuko desiste de queimar os ovos e, com as crianças, faz um túmulo e um funeral para os ovos, acreditando assim haver neutralizado a má ação.

Sua intenção de proteger a casa de uma ameaça futura, contudo, não evitou que a Mãe, apesar de não ser supersticiosa, visse os ovos de cobra, animal que the passara a causar aversão desde a morte do marido. A Mãe, ao observar o enterro dos ovos, comentou que Kazuko era uma pessoa cruel. O resultado foi até negativo, pois a moça acabou atraindo para si maior rejeição da mãe, que certamente teria “pressentido algum sucesso funestíssimo". Kazuko nada sente em relação às cobras. Elas não têm, para ela, o mesmo sentido que têm para a Mãe, que sente "um temor reverente" pelos ofídios. Diante, porém, do aparecimento de uma cobra, que parecia ser a mãe dos ovos enterrados, sente um mau-presságio e pensa:

Ah, o rosto dela [da mãe de Kazuko] tem qualquer coisa daquela cobra triste (que perdeu a cria). E a outra, feia como um mamushi que habita meu peito, haveria um dia de matar a cobra-mãe tão triste e tão linda.(Cap. I).

Esse mau-presságio é um sinal da morte da Mãe. A existência de Kazuko não é suficiente para manter a mãe viva. Ela aguarda o filho e só morre, serenamente, depois de tê-lo perto de si. O incidente com a cobra poderia ter aparecido depois, como explicação dos fatos, mas estando no início tem um efeito bem maior, assim 
como o pequeno incêndio causado por Kazuko pouco tempo depois, como prenúncio que vem a confirmar o destino de sua família.

Dazai recorre à tradição dos contos populares e maravilhoso que deve ter ouvido quando criança de sua mãe de criação e da ama-de-leite, que viveram na região do extremo norte da ilha principal do Japão, famosa por seus contadores de histórias.

Essas crendices populares aparecem também na morte da Mãe, que só ocorre depois que o filho Naoji volta para o seio familiar, no outono. A Mãe gosta da acácia-de-Constantinopla, uma flor do verão que ela não tem no jardim da casa em Izu. A única flor dessa estação que está ali é a espirradeira, que ela não aprecia. A Mãe comenta com Kazuko, que está cuidando do jardim:

Dizem que quem gosta de flor de verão, morre no verão. [...] Eu prefiro as rosas. Só que, como elas florescem nas quatro estações, a pessoa que gosta de rosas morre na primavera, morre no verão, morre no outono, morre no inverno: tem de morrer quatro vezes, sabe? (Cap. II).

E, assim, ela poderia morrer em qualquer época, desde que tivesse o filho Naoji perto de si.

Essa pequena família, que já não tinha o esteio e chefe, vivia amparada pelo tio Wada e, por recomendação dele, vendeu a casa da família em Nishikata, Tóquio, e mudou-se, no início de dezembro de 1945, para a casa que compram do visconde Kawada, localizada à beira da linha férrea entre Suruga e Izu, cerca de $100 \mathrm{~km}$ a leste de Tóquio, onde tem início a narrativa.

As expressões usadas na obra e que remetem a essa época - "ano em que o Japão se rendeu incondicionalmente"; "Terminada a guerra, e operada a transfiguração do mundo" (Cap. I) - dizem respeito a um período muito controvertido na história do Japão, pois o fim da guerra pareceu a salvação para uns e a perdição total, para outros. Dazai pertence ao segundo grupo, que vê, na democratização e na reconstrução japonesa comandada pelo General MacArthur, o subjugar do povo japonês.

Okuno comenta que, com a derrota na guerra, Dazai sentiu vergonha de ser japonês e se conscientizou de que era a chegada a hora da revolução, que o homem 
precisava mudar radicalmente e que Pandora no Hako (A Caixa de Pandora, 1945) foi escrita com o desejo de renascimento dos japoneses. Decepcionou-se com o fato de que, mesmo depois da derrota, os japoneses e a sociedade não mudaram absolutamente. Revoltou-se contra os Estados Unidos e voltou-se para a autodestruição, a autonegação, como forma de demonstrar sua verdadeira revolta, negação e contrariedade pelo sistema vigente. Nessa época em que procurou virar do avesso toda a moral, surgiram em suas obras expressões como Gi no tame asobu (Viver de brincadeiras para fazer justiça), Kodomo yori oya ga daiji (Os pais são mais valiosos que os filhos), Katei no kōfukuwa shoaku no moto (A felicidade da família é a origem de todos os males), Utsukushii mono wa horobosaneba naranu (Tudo que é belo deve ser destruído), Ningen wa koi to kaikaku no tame umarete kita (O ser humano nasceu para a paixão e para a revolução), ${ }^{7}$ esta última existente em Pôr-do-Sol.

É como se a colonização do Japão estivesse acontecendo depois de ter sido adiada por décadas e numa época em que a maioria das colônias já havia se tornado independente. A ditadura japonesa terminara, mas começava a ocupação americana oficial. A luta pela liberdade nunca haveria de chegar. Não havia esperanças. Naoji não tinha forças para enfrentar a realidade. O estudioso Watabe apresenta uma canção que esteve na moda no Japão por volta de 1946 e que Dazai inseriu na obra Haru no Kareha (Folhas Secas de Primavera) escrita nesse mesmo ano. Anata já/nai no yo/anata jál nail anata o/ mattel ita no já nail. (É você/ não, é não/ é você/não/você/o esperado/não era.). O próprio Dazai teria comentado que "você" se referiria aos Estados Unidos, ${ }^{8}$ mas muito mais que as tropas de ocupação e a cultura americana que invadiram o país, o estudioso acredita que deve haver um sentido mais profundo, ou seja, que "você estaria indicando a cultura leviana do Japão do pós-guerra e essa própria época, contra a qual Dazai se revoltava"9.

Aparentemente, a mãe de Kazuko aceitara a nova situação com desprendimento, confiando às cegas no bom-senso do irmão, mas depois de tudo

\footnotetext{
${ }^{7}$ Takeo OKUNO, Shinchō Nihon Bungaku 35 Dazai Osamu Shū, p. 643.

${ }^{8}$ Segundo Okuno Takeo, Dazai teria dito pessoalmente a Yoshimoto Takaaki.

${ }^{9}$ Yoshinori WATABE, Nihon Bungaku Shiryō Sōsho, Dazai Osamu II, p. 56.
} 
resolvido e prontos os preparativos para a mudança, na véspera da partida, ela mostrou uma fraqueza assustadora e Kazuko ficou sem ação:

Com uma voz envelhecida e fraca, mamãe disse então coisas surpreendentes, que me deixaram estupefata:

- Sabe? Vou a Izu porque você está... porque você está comigo; só porque você está comigo.

Senti um choque no coração e, sem querer, perguntei:

- E seu eu não estivesse?

Ela pôs-se a chorar de repente:

- Melhor morrer. Eu também queria morrer nesta casa em que seu pai faleceu.

Depois de dizer essas coisas entrecortadamene, seu choro se tornou mais forte.

Até então, ela nunca demonstrara semelhante fraqueza, nem jamais chorara assim na minha frente; fosse por ocasião do falecimento de papai; fosse quando me casei, ou mais tarde, quando voltei para junto dela com um bebê no ventre: quando a criança nasceu morta no hospital; quando cai doente e fiquei de cama; e nem mesmo chorara quando Naoji praticou más ações; jamais ela se mostrou tão fraca. Nos dez anos que se seguiram ao falecimento de papai, mostrou-se sossegada e meiga como sempre. Prevalecemo-nos disso e crescemos mimados. Entretanto, mamãe já não tem mais dinheiro. Gastou tudo em nosso proveito, meu e de Naoji, sem nem sequer hesitar. E, dessa maneira, saindo desta casa onde vivemos tantos anos, teremos de recomeçar a vida, abandonadas, sós, numa casinha de campo em Izu. Se ela fosse maldosa e sovina, se fosse dada a nos censurar e, ainda, se, às ocultas, pensasse apenas em amealhar dinheiro; nesse caso sim, jamais ficaria com vontade de morrer, por mais voltas que o mundo desse; e, no entanto, ai que inferno horroroso, miserável e sem salvação é a gente ficar sem dinheiro! Como se o tivesse sentido pela primeira vez na vida, com o coração opresso, querendo chorar e sem podê-lo de tanto pesar (seria esta a sensação do que chamamos a austeridade do viver?), era como se me encontrasse paralisada; fiquei quieta como uma pedra, deitada com o rosto voltado para cima. (Cap. I) 
Essa descrição mostra quão grande foi a dor dos nobres que se viram obrigados a se desfazer de toda a riqueza para sobreviver com as regras da nova sociedade democrática que surgia no Japão.

A mesma dor de Dazai pode ser vista nas palavras de Kazue ${ }^{10}$, a protagonista da peça teatral Fuyu no Hanabi (Fogos de Artificio do Inverno), escrita em 1946:

[...] Dizem que o Japão perdeu, perdeu, mas eu não acho assim. Ruiu, entende? Desmoronou, sabe? Mesmo com o território do Japão sendo ocupado de cabo a rabo, e todos nós, sem exceção, sendo reféns, bem, não se sente vergonha; [...] Afinal, para que estamos vivendo? É realmente incompreensivel. ${ }^{11}$

Foi em dezembro de 1945 que o Quartel General publicou o memorando sobre a reforma agrária, cuja primeira fase teve início em fevereiro do ano seguinte. Logo no início de 1946 ocorreu a declaração pública do Imperador negando sua ascendência de origem divina; em março, foi promulgada lei de controle de preços e interrompeu-se a circulação da antiga moeda iene; em julho, o projeto de lei da segunda reforma agrária foi aprovado pelo Gabinete do Primeiro Ministro; em novembro, a Constituição do Japão foi promulgada.

As novas mudanças e as reformas tiraram todos os privilégios da classe nobre. Não foi sem razão, portanto, que a mãe de Kazuko entrou em estado depressivo e, ao vê-la, a protagonista disse: "A chorar, desejei verdadeiramente morrer ali mesmo, em companhia dela. Já nós duas não precisávamos de nada. Achei que nossa vida havia terminado quando saímos da casa da rua Nishikata” (Cap. I).

Na nova casa em Izu, mãe e filha passaram o inverno e receberam o Ano Novo, a primavera, com a vida aparentemente em ordem e feliz em meio ao ar puro, o clima agradável e a gente hospitaleira do vilarejo. E foi nela que ocorreu a cena da sopa em que a mãe soltou o "Ah?", estopim para toda a reflexão até o momento da narradora-protagonista, incomodada com o sentimento que a mãe nutria por Naoji e que levava no peito a ferida aberta de uma rejeição que se tornou natural em função dos costumes: a valorização do primogênito e o descaso para com os demais, sobretudo para com a mulher.

\footnotetext{
${ }^{10}$ Kazue é composto pelo ideograma kazu, "número", e $e$, "galhos". Kazuko tem ideograma apenas para $k o$, que significa "filha" ou "criança" e serve como sufixo nos nomes femininos.

${ }^{11}$ Tradução nossa. Trecho extraído de Norio OKUBO. Nihon Bungaku Kenkyū Shiryō Sōsho, p. 87.
} 
Kazuko revoltou-se ainda mais com essa sua condição quando a mãe lhe contou que tivera notícias, pelo tio Wada, de que Naoji estava vivo e voltaria depois de se tratar do vício de ópio. Para não dar despesas à família, a Kazuko só restava como alternativa deixar o lar, e o convívio da mãe e do irmão para ir viver como agregada na casa de um príncipe com laços consangüíneos, servindo como professora particular da princesa. Sentiu-se usada, ludibriada pelo amor de sua mãe, que afirmara optar pela continuidade de sua vida em Izu porque tinha a ela, Kazuko; agora, que o filho protegido estava para voltar, era descartada sem a menor hesitação. Kazuko recusou-se a acatar tamanha arbitrariedade e decidiu resolver o problema por conta própria e sair de casa. Essa decisão, no entanto, foi adiada ao fazer as pazes com a mãe e com a chegada do irmão, o que ela caracterizou como o início do "verdadeiro inferno" (Cap. II) para eles.

A guerra não foi penosa apenas para Naoji, que combateu nas ilhas do sul, região considerada a pior de todas as frentes de batalha. Kazuko também prestou serviços braçais mediante convocação "na época em que a evolução da guerra atingiu finalmente um ponto desesperador.” (Cap.II)

Todo o povo japonês teve sua parcela de sacrifício durante a guerra, em maior ou menor escala. Não podemos esquecer que o Japão esteve em sucessivas guerras desde o final do século XIX, iniciadas a partir da guerra sino-japonesa em 1894. Apesar dos intervalos entre uma e outra, a militarização e o avanço ao continente chinês em busca da dominação não deram trégua ao povo.

Kazuko assumiu uma postura de não falar sobre a guerra, mas acabou contando o episódio de sua convocação, ${ }^{12}$ referindo-se a ele como "relato de preciosas experiências", 13 pois naqueles dias de trabalho árduo de baixo de sol e de chuva ela descobriu que era capaz de enfrentar qualquer trabalho pesado. O poema utilizado por Kazuko para retratar suas lembranças sobre aqueles tempos da Segunda Guerra é bastante elucidativo.

\footnotetext{
12 Em julho de 1939 foi promulgada a lei de convocação da população para a guerra; internamente, o Japão mobilizava o povo como recurso.

${ }^{13} \mathrm{Na}$ edição em língua portuguesa do Pôr-do-Sol, "preciosas experiências" estão diluídas no contexto. Seguimos o original em termos de resgatar a expressão kichō naru taiken dan, que vem entre aspas.
} 


\author{
No ano passado não houve nada ${ }^{14}$. \\ No ano retrasado ${ }^{15}$ não houve nada. \\ E no ano anterior a esse, também não houve nada.
}

A vida para o povo japonês não deve ter sido diferente. Não sendo donos da própria vida, nada, realmente, haveria de acontecer de interessante ou de importante para eles, além da continuidade da situação. E podemos ir um pouco além do "não houve nada" que ressoa desses versos - em japonês, nani mo nakatta - se observarmos que a expressão também significa "não tinha nada". Isso equivale a dizer que era um vazio total, no nível material ou no psicológico e espiritual.

Naoji voltou aparentemente curado do vício de ópio e demonstrou seu carinho e preocupação com a mãe, forçada a viver naquele mundo que ele considerava inadequado para ela. Apesar disso, Naoji continuou com a vida ociosa, sempre recebendo mesada da mãe e se ausentando por vários dias. A guerra, para ele, era uma página virada. Convidado por Kazuko a falar a respeito, ele respondeu:

- Não me lembro de nada. Não me ficou nada. Esqueci-me de tudo. Cheguei ao Japão, tomei o trem, e, da janela, os arrozais irrigados me pareceram deslumbrantes. Só isso. Desligue a luz. Não posso dormir assim. (Cap. III)

A mãe era atenciosa e obediente em relação ao filho e Kazuko não continha sua raiva. Seus dias também eram cercados pela sensação de desamparo e vontade de morrer. E ela descobriu que desde muito tempo Naoji também vivia às voltas com o desespero e via a morte como solução.

Kazuko encontrara um caderno do irmão intitulado "Diário de Yūgao"16 cerca de seis anos antes, quando ele se tornara dependente de ópio; ao lê-lo, recordou-se de

\footnotetext{
${ }^{14}$ Grifo nosso. Em japonês, nani mo nakatta significa também "não tinha nada".

${ }^{15}$ Cf. Pôr-dol-sol. Cap. II. "No ano anterior" constante no segundo verso, corresponde a issakunen, ano retrasado. No poema como um todo, percebe-se que se trata do ano anterior ao mencionado no primeiro verso, mas para enfatizar a idéia de retrocesso no tempo preferimos utilizar "No ano retrasado".

16 Calonyction aculeatum, tipo de trepadeira de flores lilases que se abrem ao final do dia. Literalmente, "rosto do entardecer". No Japão, trepadeiras semelhantes a ela recebem o nome popular de acordo com o momento em que as flores desabrocham. Assim, temos asagao, "rosto da manhã"; hirugao, "rosto da tarde"; e yūgao, nome popular de yorugao, "rosto da noite". V. Anexo, Imagem 2. Em Pôr-do-Sol, a nota explica que se trata da corriola, flor que se abre ao entardecer e que faz alusão ao capítulo de mesmo nome do Genji Monogatari. Mais precisamente, trata-se do Caderno 4, e Yūgao é o nome da moça que é morta por um espírito que se apossa de seu corpo. Vizinha da ama do príncipe Hikaru Genji, o protagonista da obra, ele a conhece quando vai visitar a ama enferma e se
} 
que, recém-casada com Yamaki, ela, atendendo aos pedidos desesperados do irmão, passou a dar-lhe dinheiro para saldar as dívidas com as drogas, vendendo inclusive jóias e roupas. Foi então que ela ficou sabendo da existência do escritor Uehara Jirō, aos cuidados de quem deveria enviar as remessas de dinheiro para Naoji que ela mandava a criada entregar. Um dia, preocupada com os valores que só aumentavam, foi à casa do escritor, encontrando-o sozinho - a esposa e filha tinham ido receber suprimentos. Saíram juntos, e beberam em clima agradável e tranqüilo. Antes de pegar o táxi de volta, Uehara beijou-a, e isso se tornou seu segredo e também seu alento, e acarretou a separação com Yamaki e a volta para a casa da mãe.

Quando resolvera sair de casa ao brigar com a mãe, assim que soube do retorno de Naoji, Kazuko mencionara que ela tinha um segredo e a mãe desejou que esse segredo desse bom fruto. Esse segredo foi revelado somente no capítulo seguinte, com a lembrança de que o vício de Naoji teria sido o motivo da separação de Kazuko com o marido, motivo esse mencionado no momento em que começou a expor esses acontecimentos, que servem de ponte para o leitor acompanhar a vida de Kazuko até aquele instante e para sinalizar em direção ao futuro dela.

Kazuko, como narradora-protagonista, vai contando a história, e a partir de uma cena desenvolve um sumário que pode ser do momento presente da narrativa ou que traz um fato passado, uma informação para atualizar o conhecimento do leitor. A narração segue o curso da memória, mas não em termos de fluxo de consciência, em que os fatos vão surgindo sem uma conexão aparente. A memória é resgatada no momento oportuno, revelando um alto nível de elaboração para a composição da seqüência narrativa, trabalhando com sinais e informações que vão sendo complementadas aos poucos.

O capítulo IV é integralmente destinado às três cartas que Kazuko enviou a Uehara. Podemos dizer que elas são as três partes de uma única carta, na medida em que não são datadas e uma complementa a outra. Dirigidas a esse escritor, as cartas revelam a necessidade e o desejo de Kazuko de arrumar sua vida junto a um tal M.C., a quem ela ama e que diz ser casado e com filhos, como Uehara, e conhecido por ele. 
Ao apelar ao destinatário que interpele M.C., Kazuko age conforme o lema que se propôs a seguir, "prudente como as serpentes e símplice como as pombas", palavras estas que ela diz serem proferidas por Jesus e que também menciona na carta. Ela expôs seu amor por Uehara, como se esse amor fosse dirigido a M.C., mas recorreu à sensibilidade dele, trazendo à baila o alento que adquiriu no primeiro e único encontro que tiveram seis anos antes, com aquele beijo inesperado. Para isso, usa figuras de linguagem:

Um dia, há seis anos, um arco-íris delicado e esmaecido desenhou-se no meu peito, e muito embora não se tratasse nem de amor nem de bem-querer, à medida que passavam os meses e os anos, esse arco-íris foi carregando as suas cores com grande beleza, e, até agora, jamais o perdi de vista. O arco-íris que surge no céu limpo depois de uma chuva tem existência efêmera e logo se apaga, mas o que nasce no coração da gente parece que não. Por favor, peço-lhe que o interpele, $O$ que acha realmente de mim? Será que me tem em conta de um arcoiris de depois da chuva? Que se apagou já há muito tempo?

Se assim for, eu também tenho de apagar o meu arco-íris. Mas sinto que ele não quer sumir-se antes de eu mesma terminar com a minha vida. (Cap. IV)

Ela apelou à memória de Uehara e, ao endereçar a carta ao destinatário no final, como é de praxe nas correspondências japonesas, escreveu: "Ilmo. Sr. Uehara Jirō (Meu Tchékhov. My Chekhov. M.C.)", deixando claro o alvo de seu amor, ou seja, ele mesmo.

Por que Tchékhov, afinal? Isso é colocado em suspense para ser elucidado paulatinamente nas cartas seguintes, que cobram uma resposta ainda não recebida e complementam as razões do coração de Kazuko.

$\mathrm{Na}$ segunda carta, a protagonista tentou desfazer a impressão de oferecida e interesseira deixada na primeira, contando que já tivera um pretendente velho e rico, um grande artista plástico, que ela recusara. Reproduziu na carta o diálogo com esse pretendente, em que lhe revelou o desejo de ter um filho e dinheiro suficiente para criá-lo; mencionou, ainda, uma carta na qual Tchékhov teria pedido a sua esposa para que tivessem um filho. Aproveitou também para dizer que atingira os 30 anos, idade recomendada para viver um amor sem sofrimento, segundo o alerta que recebera aos 19 anos de sua professora, que regressava para a Inglaterra. Essa recordação também 
é inserida num passe de mágica, durante seu diálogo com o pretendido. A narração é conduzida de modo tão habilidoso que acabamos esquecendo que se trata de um parêntese, usado nas já mencionadas situações. O comentário maldoso que o pretendente faz sobre uma possível venda da propriedade nos traz de volta ao diálogo que estava sendo travado entre os dois.

Novamente, porém, somos surpreendidos pela citação da famosa peça de Tchékhov, O Jardim das Cerejeiras (1903-4), ${ }^{17}$ comédia em quatro atos, e da personagem Lopakhin, comerciante que adquire em leilão esse jardim "mencionado até nas enciclopédias", ${ }^{18}$ do qual se orgulha sua proprietária Liubov Andréievna Raniévskaia, que diz: "Em toda a região não há outro jardim de cerejeiras tão grandioso quanto o nosso", ${ }^{19}$ contrariando o amigo, que acha melhor derrubar as cerejeiras. Segundo ele, a "grandiosidade desse jardim resume-se ao fato de ele ser tão grande. Mas a produção de cereja é boa só a cada dois anos, quando muito, e mesmo então não se sabe o que fazer com ela. Ninguém a compra". ${ }^{20}$ Enfim, uma inutilidade para os tempos capitalistas, como o é a propriedade da família de Kazuko. Grandiosa, de elevado valor sentimental, mas que mantida como estava não servia para sustentá-la.

A estudiosa Yanagi Tomiko, ${ }^{21}$ que focaliza a recepção de Tchékhov por Dazai, apresenta sua visão de que a imagem de $O$ Jardim das Cerejeiras está em Pôr-do-Sol, visão essa que ela diz ser compartilhada pelos estudiosos Okuno Takeo e Kamei Katsuichirō. Yanagi Tomiko atribui a influência das obras de Tchékhov na produção dessa obra de Dazai, que associa a destruição de sua casa à do sentimento do autor, com base nas cartas escritas em 1944, como a endereçada a Ibuse Masuji, em 15 de janeiro, dizendo: "Minha casa em Kanagi, por exemplo, é um Jardim das Cerejeiras". Uma carta de abril, enviada a Kawamori Yoshizō, conta sobre sua releitura das obras completas de Tchékhov. Na ocasião, no final da Segunda Guerra

\footnotetext{
17 Usamos o título da tradução de Gabor Aranyi, em Teatro II - As Três Irmãs/O Jardim das Cerejeiras, publicado pela Editora Veredas, em 2005.

${ }^{18}$ Fala de Gaiev, irmão de Liubov Andréievna, a protagonista proprietária de terras. Cf. O Jardim das Cerejeiras, p. 82.

${ }^{19}$ Trecho extraído de $O$ Jardim das Cerejeiras, p. 82.

${ }^{20}$ Idem.

${ }^{21}$ Tomiko YANAGI, Nihon Bungaku Kenkyū Shiryō Sōsho Dazai Osamu, 166-176.
} 
Mundial, Dazai estava refugiado em Kanagi, sua terra natal, e de lá acompanhou a queda dos nobres decorrente das mudanças ocorridas em todo o Japão.

A estudiosa menciona a tese de Usui Yoshimi para mostrar que Dazai construiu um romance peculiar com um material bem conhecido e próximo a ele; em uma das personagens, incutiu seu sonho (dōkei); em outras duas, seu espírito, sua alma (tamashii); e na quarta, sua própria imagem (onore no sugata). Segundo ela, ao fazer isso o autor fragmentou sua própria essência e enfraqueceu a independência de cada uma das personagens.

Yanagi Tomiko aponta que a mãe de Kazuko foi construída tendo em mente Raniévskaia, protagonista de $O$ Jardim das Cerejeiras, pois as duas damas são pessoas sem qualquer noção do valor monetário. Para ela, Dazai aproxima-se desse autor russo, que tem os olhos na destruição e que descreve o ser humano que desistiu por completo de lutar para viver e que vive à mercê da correnteza, sem ao menos pensar em sair dela. A estudiosa, para mostrar a semelhança entre Raniévskaia e a Mãe, cita a fala de Ánia e de Kazuko, personagens que respectivamente fazem o papel de suas filhas, criticando a falta de noção de suas mães em matéria de dinheiro. Os trechos correspondentes ao mencionado por Yanagi são:

Em Ánia:

A essa altura já tinha vendido há muito tempo a casa de campo em Menton e não lhe restava nada, mas nada mesmo. A mim tampouco sobrara um único copeque, e foi um milagre divino termos conseguido de algum modo voltar para casa. E além disso, mãezinha não faz a mínima idéia sobre nada... Lá estamos nós sentados no carro-restaurante para comer alguma coisa, e é claro que ela pede logo o prato mais caro e dá um rublo de gorjeta a cada um dos garçons. $^{22}$

E em Kazuko, “[...] mamãe, que em matéria de dinheiro entende menos que uma criança”. (Cap. I)

Desse modo, para Yanagi Tomiko, Tchékhov e Dazai enfatizam essas duas protagonistas femininas como portadoras da beleza de não possuir consciência sobre a classe nobre a que pertencem e de não ser exibicionista, e a originalidade de Dazai

${ }^{22}$ Extraído do Primeiro ato de O Jardim das Cerejeiras, p. 77. 
em relação a Tchékhov estaria no momento da morte da Mãe, ao qual o autor japonês deu um acabamento diferente da personagem de Tchékhov. Diz a estudiosa que, depois que a mansão passou para mãos alheias, a mãe de Kazuko consegue suportar a vida numa casa de campo onde não tem liberdade, mas talvez pelo cansaço mental fica doente do pulmão e morre serenamente. Dazai põe o sentido disso nas palavras de Kazuko:

$A i$, não terminaria como mamãe, não conseguindo sobreviver daqui para diante, pessoas que, sem lutarem contra os homens, os odiarem e nem sequer se sentirem despeitadas, consigam pôr termo à existência de uma forma assim bela e triste? Quem está morrendo torna-se belo. O fato de viver, o fato de permanecer vivo, isso é que me parece extremamente feio; cheira a sangue; é nojento. (Cap. $\mathrm{V})$.

Yanagi Tomiko afirma que, no mundo de Ranievskaia, o pecado e o amor e a destruição e a beleza estão entrelaçados, e neles reside a tristeza do ser humano. Tchékhov valoriza a realidade de Ranievskaia como ser humano, ao passo que Dazai cria a beleza da Mãe, eliminando sua natureza de fêmea voltada para o amor do sexo oposto, retirando-lhe a fetidez humana; para Tchékhov, a destruição e a beleza estão ligadas, mas não de modo absoluto; para Dazai, a vida liga-se à feiúra, e a morte, equivalente à destruição, liga-se à beleza.

As palavras de Kazuko resumem bem as características de sua mãe: “Os maus vivem muito. As pessoas belas morrem logo" (Cap. I). Como mulher da nobreza, a mãe de Kazuko e de Naoji apresenta um requinte digno de sua classe, mas sem perder a simplicidade e a inocência. Ela é uma mãe afetuosa, que ama os filhos de modo incondicional, amparando o filho dependente de drogas e de álcool, que não cria sua independência, e a filha, que volta para casa depois de uma separação conjugal. Vela pelos dois e deles recebe o mesmo amor. Dentro dos limites possíveis, nenhum dos filhos quer abandoná-la. Kazuko adia seu intento de sair à procura de Uehara quando a mãe adoece e espera até que ela melhore; Naoji só decide pelo suicídio depois da morte da mãe. Apegada à casa da família e às lembranças dos tempos de glória, já à beira da morte, a Mãe ainda deseja ver a foto do Imperador, publicada em um jornal - ela acredita que ele estaria mais feliz, agora que é livre -, e 
não se esquece de deixar palavras carinhosas para Kazuko, atarefada com os cuidados para com ela e os visitantes.

Yanagi Tomiko observa, ainda, um aproveitamento em Pôr-do-Sol das personagens principais de $A$ Gaivota, ${ }^{23}$ comédia em quatro atos, também de Tchékhov, escrita entre 1895 e 1896.

Kazuko, segundo Yanagi Tomiko, corresponderia a Nina, protagonista jovem e bela que troca o namorado Trepliov por Trigórin, personagem correspondente a Uehara, escritor de meia-idade que se lhe apresentava como oportunidade para concretizar seu desejo de ser atriz. Descreve-a como alguém que vive o perigo da destruição por seguir seus impulsos e ser fiel a sua voz interior, livre dos padrões do senso comum. A estudiosa admite que Kazuko não corresponderia a Nina se for considerada a afirmação de Kazuko - "Eu não estou amando um autor como a Nina de A $_{\text {Gaivota" }}{ }^{24}$ - e a existência de Ota Shizuko como protótipo dela, mas defende que Dazai criou Kazuko tendo Nina em mente, alegando que em Hi no Tori (Pássaro de Fogo), romance inacabado de Dazai, o autor havia criado a personagem Takano Sachiyo, que faz papel de uma atriz que lembra muito Nina.

Yanagi Tomiko aproxima Kazuko de Nina em sua atitude de arriscar a vida, de não preservar a si mesma; nesse aspecto, observa que Dazai segue outro rumo: Nina concentra-se em seu objetivo de ser atriz sem que as portas estejam fechadas para ela, ao passo que Kazuko foge para um mundo fora dos padrões convencionais, apoiando-se em Uehara e levada por um niilismo desesperado. A estudiosa mostra o sentimento de Kazuko no trecho: "Ideologia destrutiva. A destruição é triste e causa compaixão, mas é bela." (Cap. V). Na obra de Dazai, não existe um único ser humano que ande em direção a um objetivo. Todos hesitam diante da destruição e estão tomados pela natureza da própria destruição.

Nina, ainda segundo Yanagi Tomiko, tem a profissão de escritor em alta consideração e acha que a fama é algo maravilhoso, mas Trigórin não lhe dá razão e revela à moça que não sabe o que é ter tranqüilidade e que é infeliz, sempre

\footnotetext{
${ }^{23}$ Utilizamos a tradução de Rubens Figueiredo, publicada pela Editora Cosac\&Naify em 2004.

${ }^{24}$ Cf. Pôr-do-Sol, segunda carta de Kazuko a Uehara no Capítulo IV.
} 
perseguido pela idéia fixa de que é preciso continuar escrevendo dia e noite. ${ }^{25}$ Kazuko vê Uehara como uma pessoa que "encharcava-se de saquê todas as noites, escrevia somente obras cada vez mais imorais e era maldito e odiado pelas pessoas de bem" (Cap. V) - no entender da estudiosa, a figura inconteste dos últimos anos de Dazai.

Naoji, por sua vez, teria seguido o modelo de Trepliov, jovem literato admirador de Trigórin e que tinha razões concretas para se suicidar, diz Yanagi Tomiko. Sua mãe é amante de Trigórin, para quem ele também perdeu sua amada Nina, cujo amor tenta recuperar em vão. Ele enfrenta a decepção no nível profissional quando começa a ser alvo do interesse das revistas e percebe que sua busca pelas novas formas continua arraigada às formas antigas. Por fim, perde a vontade de viver diante do conflito com a mãe, da decepção amorosa e da incapacidade de descobrir sua missão. No caso de Naoji, há motivos semelhantes aos de Trigórin, mas, como ele próprio diz: "a custo vivo ao ar livre e ao sol desta vida" (Cap. VII). Essa personagem apresenta a insegurança de um ser humano fraco e sua relação com a mãe e a irmã não dá mostras de que ele tenha um conflito forte o suficiente que o leve ao suicídio. Nele, a destruição está nas profundezas da consciência. Yanagi Tomiko explica que, tanto no "Diário de Yūgao" quanto no testamento, são inseridas experiências do próprio Dazai, o que faz que a devastação mental e a psicologia do suicídio de Naoji sejam diferentes do que ocorre com Trepliov.

Dessa maneira, Yanagi Tomiko interpreta que Dazai acrescentou uma dose mais forte de destruição no sentimento de Kazuko, Uehara e Naoji do que a de Tchékhov em Nina, Trigórin e Trepliov.

Sem dúvida, a interpretação de Yanagi Tomiko quanto à utilização das personagens das duas obras de Tchékhov por Dazai demonstra que a proximidade observada é resultado da inspiração que o autor japonês obteve nessas obras russas, e que a distância entre elas evidencia seu trabalho de elaboração em Pôr-do-Sol.

\footnotetext{
${ }^{25}$ Cf. A Gaivota, longo diálogo entre Nina e Trigórin no Segundo Ato. Yanagi deu apenas um resumo do conteúdo discutido pelas duas personagens.
} 
É preciso lembrar, no entanto, que é comum Dazai fazer uso de outras obras em suas criações, como ocorre com a obra Otogizōshi (Contos Maravilhosos, 1945). Ela é composta pelo prefácio e quatro partes que parodiam quatro contos maravilhosos antigos, todo com um fundo moral, e usam títulos semelhantes. Kobutori aproveita o enredo de Kobutori Jiisan (Velhinho que Extraiu o Calombo) também baseado no Oni ni Kobu Toraruru Koto, do Rolo I da coletânea Uji Shūi Monogatari, do século XII - a história de um velhinho que se livra de um grande calombo que tinha na face graças aos ogros que encontrou na floresta. Urashima San (Sr. Urashima) segue a história de Urashima Tarō, personagem lendária que aparece em Yüryakuki, Tango Fudoki, Man'yōshū e Urashimako Den, um pescador que foi levado ao Palácio do Dragão no fundo do mar. Ali, viveu cercado de todo conforto durante três anos, ao lado de uma linda mulher, que na hora da despedida entrega-lhe uma caixa conhecida pelo nome de tamatebako, que ele promete não abrir jamais. Voltando a sua terra natal, no entanto, ele quebra o juramento e dela sai uma fumaça, que o transforma num velhinho.

Kachikachi Yama (Monte Duro como Pedra) usa o mesmo nome do original, provavelmente escrito por volta do século $\mathrm{XV}$, que narra o mérito de um coelho que ajuda um velhinho a vingar sua esposa morta por um texugo. Shitakiri Suzume $(O$ Pardal de Língua Cortada) também tem o mesmo título do original, escrito supostamente no final de Muromachi, que narra a história de um pardal que teve a língua cortada e foi banido por uma velhinha que alegava ter ele ciscado a papa de arroz. O velhinho vai visitar o pardal em casa, e este lhe dá cestos como lembrança. $\mathrm{O}$ velhinho escolhe o mais leve e dele saem tesouros. Invejosa, a velhinha resolve visitar o pardal e dele ganha um cesto bem pesado de onde saem cobras, taturanas e outros animais peçonhentos.

$\mathrm{Na}$ visão do estudioso Watabe Yoshinori, ${ }^{26}$ porém, a obra de Dazai não tem vilões como nas originais. Na história de Kobutori, não há nenhum incidente ruim, as pessoas são boas e nem o velhinho beberrão nem os ogros praticam más ações; o mesmo ocorre em Shitakiri Suzume. Para os demais pardais, a mulher que cortou a

\footnotetext{
${ }^{26}$ Yoshinori WATABE, Nihon Bungaku Kenkyū Shiryō Sōsh,Dazai Osamu II, p. 56.
} 
língua do colega não é má, só estava mal-humorada naquele dia. Ela também recebe a consideração do velhinho, que lhe é grato por estar vivendo bem no momento.

A respeito dessa obra de Dazai, o estudioso Tōgō Katsumi explana:

O Prefácio já contém o tema da obra. Como mostra a combinação de Bōkū Zuka (Esconderijo Antiaéreo) com Monogatari (Narrativa), observa-se a oposição entre realidade e sonho, a vida comum do dia-a-dia e a vida incomum. A mãe (esposa) "reclama" ao pai (esposo), que é o próprio autor, do aperto que é o esconderijo antiaéreo. O pai, no dia-a-dia, é um inútil que não consegue nem cavar uma vala. Mas, mesmo fraco e incapaz na vida cotidiana, ele "não é pouca coisa" em matéria de "possuir a técnica fabulosa de criar uma narrativa" que está além da realidade. $O$ conflito entre uma familia realista e um homem que "não é pouca coisa" apesar de inútil no dia-a-dia, é um padrão que se encontra no Otogizōshi com algumas variações. $O$ velhinho Kobutori é um beberrão solitário, "sempre com cara de insatisfeito" mesmo vivendo numa casa "magnifica" com uma velhinha "solene" e um filho que é "um santo". Urashima Tarō, um "primogênito de uma família tradicional famosa" sai de casa respondendo algo incompreensivel como "as pessoas possuem um destino" às críticas da irmã e irmão mais novos que são realistas. Kachikachi Yama tem uma montagem um pouco diferente das outras três histórias, mas mesmo assim o texugo, feio, tosco e comilão, recebe o troco impiedoso e cruel da coelha, uma linda virgem de 16 anos de idade. E o velhinho do Shitakiri Suzume, na realidade, é "o terceiro filho de um milionário" e no momento é considerado pela família como "tolo frágil e problemático" que também sempre é alvo dos ataques da "velhinha realista". Em suma, essa obra é a história da fuga dos homens imprestáveis que não conseguem viver bem no mundo real. ${ }^{27}$

Dazai traz as personagens do conto de fadas para a realidade do presente. A felicidade só existiria antes do nascimento e depois da morte. Ou no fundo do mar, no palácio do dragão em que a "consciência" já não existe e, conseqüentemente, a censura, a cobrança, a reclamação que geram o medo da vida. As pessoas são como:

Urashima que procura um lugar em que as pessoas não censurem umas às outras e segundo a tartaruga, o palácio do dragão é o local em que isso não acontece. A 
"censura" é a "palavra" que, segundo a tartaruga, "é o que nasceu do medo de viver". Sendo assim, a palavra é a própria consciência, e o medo de Dazai provém da cisão da existência e da consciência. E esse "medo" cria a "palavra" que gera o "cômico". Por conseguinte, o mundo sem "palavras" é o mundo onde não existe a "consciência". E qual seria esse mundo de "claridade opaca" da inconsciência em que não existe a "palavra"? Em termos dogmáticos, seria algo próximo do útero materno antes do surgimento da consciência ou o mundo da morte, após a destruição da consciência. ${ }^{28}$

Encontramos uma fala semelhante de Kazuko, que mostra a felicidade como algo incompreensível e, portanto, inexprimível. Trata-se do momento em que Kazuko está tricotando para disfarçar a apreensão pela morte já aguardada da mãe, ao ouvi-la dizer que não tem nem lágrimas para chorar vendo a foto do Imperador, que ela acreditava ter sido libertado com o fim da guerra, e "rir como se sentisse soledade". Kazuko pensa:

Não estaria ela feliz agora? [...] Isso que se chama sensação de felicidade não seria algo como pepitas de ouro (pó dourado) a brilhar soturnamente (frouxamente) no fundo de um rio de tristezas? Passado o último degrau da tristeza, a estranha sensação de felicidade; então, sua majestade, mamãe e eu certamente somos agora felizes. Manhã quieta, outonal. Quintal de outono, onde batem os raios de sol, suaves. Deixei de fazer tricô, e contemplei o mar brilhando à altura do meu peito. (Cap. V).

Para concluir: “A vida é incompreensível”. E ser complementada pela mãe: “Eu não a compreendo. Não há quem a compreenda, não será assim? Por mais que passe o tempo, todos somos crianças. Não compreendemos coisa alguma” (Cap. V).

A tristeza traz o riso, e a felicidade está submersa n’água como o palácio do dragão no fundo do mar, brilhando soturnamente. Só se pode ter a certeza de que se tratam de pepitas de ouro se mergulhar para encontrá-las. E o brilho soturno pode levar para um outro mundo, o mundo do palácio do dragão, onde Urashima poderia ter encontrado a felicidade ou a morte, uma vez que, em Dazai, a fórmula Vida = Fealdade, Infelicidade e Morte $=$ Beleza, Felicidade é plenamente aplicável e água

\footnotetext{
${ }^{27}$ Katsumi TŌGŌ, Nihon Bungaku Kenkyū Shiryō Sōsho, Dazai Osamu II, p. 212-3.

${ }^{28}$ Ibidem, p. 214.
} 
revela-se como elemento purificador, uma conexão com as tantas frases retiradas da Bíblia que Dazai também utilizou como mais uma obra que merecia ser destacada. Por isso, consideramos que essa obra que leva no título o nome do diário de Ōta Shizuko, e vai além de um aproveitamento das personagens das obras de Tchékhov.

Em Pôr-do-Sol, Dazai parodia sua própria vida, parodiando também as obras que quis enfatizar. Nessa obra, particularmente, observamos uma consonância da conhecida natureza dissimulada do autor japonês, com as duas comédias de Tchékhov. Dazai, como décimo filho de onze irmãos, sexto entre os homens, era a sobra que não fazia diferença na família. Sempre foi reconhecido por sobressair-se nos estudos, mas por volta dos 20 anos sentia-se um peixe fora d'água no convívio com os irmãos. Começou a questionar a vida alegre da família e dos amigos em meio às falsidades. Decepcionou-se com o mundo dos adultos, revoltou-se e sentiu-se inseguro. Não se conformava em ter de aceitar esse mundo sujo e questionava o que é o ser humano, a justiça, a beleza, a verdade e o amor. Tentou manter, por tempo indeterminado, a fraqueza, a pureza e a autenticidade humanas. Achando-se diferente de todos, recorreu ao disfarce de palhaço para tentar manter um relacionamento com as pessoas. Podemos, por isso, dizer que em Pôr-do-Sol o autor é esse mesmo zombador que revela a seriedade, o desespero e o sofrimento.

Não é preciso ter a informação de que Dazai Osamu releu as obras completas de Tchékhov durante o refúgio em sua terra natal logo após a Segunda Guerra Mundial, mais precisamente entre $1^{\circ}$ de agosto de 1945 e 14 de novembro de 1946, para explicar que ele usou as duas peças russas, $A$ Gaivota e $O$ Jardim das Cerejeiras, como referência para escrever Pôr-do-Sol. Os títulos dessas duas comédias vêm citados textualmente nos contextos que lhe são pertinentes; as alusões a suas personagens - como Nina, da primeira, e Lopakhin, da segunda - são claras e o nome de Tchékhov surge num primeiro instante como camuflagem - pelas iniciais "M.C." - e como revelação - pela expressão "My Chekhov", segundo a grafia do inglês que é a mais comum no Japão. Por fim, a carta endereçada a Uehara no final da obra descortina a multiplicidade do M.C. também como "My Comedian", ou seja, alusão ao dramaturgo russo dessas duas comédias sérias mencionadas. A aparente contradição entre o tema da destruição abordada por esse gênero é explicada por 
Rubens de Figueiredo, o tradutor de A Gaivota, no Pósfácio. Tchékhov advertia Konstantin Stanislávski, diretor da companhia de teatro que também representou o papel de Trigórin, que:

Trigórin devia usar um sapato furado, vestir calça xadrex e fumar charuto fedorento, em vez de mostrar-se como um dândi. O dramaturgo também reprovou a concepção de Stanislávski para o final do terceiro ato - a cena da despedida -, em que o diretor imaginara trazer para o palco um grupo de mães e crianças chorosas. No geral, Tchékhov insistia em que os atores evitassem toda ênfase no sentimento. Isso talvez ajude a esclarecer uma dúvida freqüente entre os seus leitores: a rubrica que Tchékhov acrescentou ao título da peça - "comédia".

Afinal, são raros os momentos de riso ou de mera alegria em A Gaivota, ao passo que não faltam, para as personagens, motivos para tristeza ou mesmo para o desespero. O problema pode se tornar compreensivel se lembrarmos que a noção rigorosa de comédia equivale menos ao riso do que ao estilo baixo - em contraste com o estilo elevado, da tragédia. Tchékhov negava crédito aos ideais alçados além da medida do cotidiano e da vida comum. Não pretendia pôr em cena gênios, heróis ou mártires desses ideais, nem os vilões que por força os acompanham. Em vez de fazer soar, no palco, falas graves a todo instante em meio a uma sucessão de acontecimentos terriveis, Tchékhov imaginara personagens que comentavam o calor, o frio ou as doenças, calavam-se por falta de assunto e pouco agiam em uma história quase desprovida de acontecimento. Pois assim a vida se mostrava, na maior parte do tempo, aos seus olhos.

A rigor, em A Gaivota, há antes coisas que não acontecem, em um enredo que parece não caminhar para parte alguma. No entanto, entre diálogos triviais, aspirações e desavenças corriqueiras, apenas rompidas por reflexões idealizadas sobre a atividade do artista, uma crise obscura se avoluma pouco a pouco. ${ }^{29}$

Como se pode ver na terceira carta, que termina com "M.C. (não são iniciais de "My Chekhov". Não estou amando o autor. "My Child")" (Cap. IV), as iniciais são ampliadas para conter o desejo de Kazuko, que quer um filho de Uehara.

Quanto às obras japonesas e estrangeiras mencionadas no livro, há um número expressivo que, diríamos, serve para criar uma intertextualidade e também

\footnotetext{
${ }^{29}$ Rubens de FIGUEIREDO, Posfácio de A Gaivota, p.108-9.
} 
ampliar o conteúdo da obra. Esse tipo de recurso mostra-se comum na tradição literária japonesa, pois o estudioso Kamei Hideo ${ }^{30}$ comenta que os autores prémodernos $^{31}$ do Japão utilizaram o chamado modoki, um tipo de reescrita muito apreciada por eles para facilitar a leitura dos clássicos e que, intencionalmente ou não, acabou criando paródias dessas obras. Ele diz que Dazai também fez uso dessa técnica de modo muito interessante em obras como Onna no Kettō (Duelo de mulheres), utilizando a tradução feita pelo escritor Mori Ogai da obra de mesmo nome de Oirenberugu Herbert para reescrever sua obra, em que o autor do original e ele próprio, Dazai, são personagens.

Nessa mesma linha, existe ainda o recurso estilístico conhecido pelo nome de honka dori, empregado nos poemas waka de 31 sílabas, desde a época clássica, e que basicamente consiste na "técnica de composição poética que aproveita uma parte de um poema antigo visando à complexidade e à sobreposição de expressões e de sentimento, para trazer a imagem do mundo ao qual esse poema antigo pertence". ${ }^{32}$ Independentemente da forma escolhida, o aproveitamento do original sempre deve ser feito sem exagero, mas também sem tanta discrição que o deixe passar despercebido. $^{33}$

Dazai Osamu seguiu essa recomendação em Pôr-do-Sol, selecionando títulos e autores que serviam a seu propósito entre os mais famosos e conhecidos, como é o caso do pintor Ogata Kōrin (1658-1716), um dos grandes nomes do inovador estilo Rin, surgido na cultura Genroku entre meados do século XVII e início do XVIII. A Kōrin, nos últimos tempos gloriosos dos nobres, a família de Kazuko solicitou que fizesse uma pintura numa porta interna da casa. Entre as obras literárias presentes em Pôr-do-Sol que produzem efeito semelhante a essa técnica poética clássica encontram-se Man'yōshū, a antologia de poemas do século VIII, Genji Monogatari,

\footnotetext{
${ }^{30}$ Hideo KAMEI, Nihon Bungaku Kenkyū Shiryō Sōsho, Dazai Osamu II, p. 79-84.

${ }^{31}$ Podemos citar Muō no Rigyo, que faz parte de Contos da Chuva e da Lua, escrito em 1778 por Ueda Akinari (1734-1809) e publicado pelo Centro de Estudos Japoneses da USP, e Nise Murasaki Inaka Genji (Falsa Murasaki, Genji Interiorano, 1829), de Ryūtei Tanehiko (1783-1842). V. Apêndice, p. 41.

${ }^{32}$ Waka Bungaku Jiten (Dicionário de Literatura Waka), organizado por Tamotsu ARIYOSHI, 1982.

${ }^{33}$ Neide H. NAGAE, Recursos estilísticos da poesia japonesa - o kakekotoba e o honkadori, p.345.
} 
a narrativa escrita pela dama da corte Murasaki Shikibu em 1008, e Sarashina Nikki, diário de 1060 da autoria da filha de Sugawarano Takasue.

A referida antologia de poemas e a narrativa de Murasaki Shikibu são citadas na terceira carta de Kazuko a Uehara:

Quero encontrar-me com o senhor mais uma vez, e, então, caso não me queira, diga-o claramente. O fogo do meu peito foi o senhor que acendeu, peço portanto que se vá depois de o apagar. Com minha força apenas, não conseguirei. Seja como for, serei salva se nos encontrarmos, se nos virmos. Isto que estou dizendo pareceria a coisa mais natural do mundo se vivêssemos na época de Mannyoo ou de Genji Monogatari. Meu desejo: tornar-me sua amante e ser a mãe de um filho seu. (Cap. IV).

Nesse caso, o desejo da narradora-protagonista de ser amante desse escritor e ter um filho dele é extremamente natural em todo o período anterior ao século XX no Japão, que tem a poligamia masculina como tradição. Sobretudo entre os séculos VIII e XI, a que essas obras pertencem, a literatura japonesa focalizou a vida das mulheres, que em sua grande maioria eram fadadas a ser amantes, quando muito a segunda, terceira ou quarta esposa. Nos diários femininos, encontramos o relato do sofrimento dessas mulheres, que ironicamente e contrariando o curso natural dos fatos, Kazuko afirma não sentir. A "carta de amor" enviada por ela a Uehara resgata uma prática comum do cortejo amoroso registrado em muitas obras literárias da mesma época. O homem enviava poemas de sua própria autoria para a moça que desejava cortejar, e esta deveria responder-lhe com outro poema, mostrando sua inteligência, sensibilidade e habilidade poética para incitar e manter o interesse de seu admirador. Essas correspondências poéticas eram trocadas antes de se iniciar o relacionamento, ou melhor, eram o próprio relacionamento que havia antes do encontro íntimo.

Notamos que Kazuko revelou-se por inteiro nas cartas endereçadas a Uehara, mostrando possuir os requisitos, e sendo eles suficientes ou não, ela se propôs a ser sua amante à força, sua esposa à força. Como não poderia deixar de ser, a regra dos antigos foi totalmente transgredida. Uehara já havia encostado os lábios nos de Kazuko - teria sido esse o "poema" dele? Seguindo a lógica da obra, esse "beijo" 
teria sido algo semelhante ao kaimami, espiar a dama de longe, pelas frestas da cortina, para ver se vale a pena iniciar a corte, dos tempos modernos, esta, é claro, às avessas. O beijo foi a motivação que Kazuko guardou na lembrança e que, seis anos depois, levou-a a tomar a iniciativa de demonstrar seu interesse por meio da carta; diante do silêncio de seu amado, foi procurá-lo pessoalmente para se impor como amante.

Sarashina Nikki, o nome do diário, é o qualificativo que Kazuko recebeu de uma colega que cortara as relações com ela quando a moça devolveu-lhe o livro de Lênin sem ler. Recordou-se do episódio para dizer que desde então já haviam se passado doze anos e nada tinha evoluído. Continuava como a protagonista do diário, a jovem sonhadora encantada pelo mundo maravilhoso das narrativas, mas se decepcionou com a vida de seus pais, o servir na corte, a vida de casada e o rigor da sociedade, se apoiou em Buda e esperou pela salvação na vida após a morte. É esse o registro de cerca de 40 anos dessa autora, que viveu entre 1008 e 1056 sem outra designação que não fosse o de filha de seu pai.

Cabe lembrar que as mulheres que criaram o glorioso universo da literatura feminina daquela época fizeram parte de um grupo seleto que era preparado para servir na corte e arrumar um bom casamento, se possível com o herdeiro do trono ou o próprio Imperador. Mesmo assim, Murasaki Shikibu, Sei Shōnagon e Izumi Shikibu, por exemplo, não são nomes próprios. Shikibu e Shōnagon são nomes de cargos governamentais; Murasaki é alusão ao Caderno Murasaki no Ue da Narrativa de Genji. Sei é a leitura chinesa do primeiro ideograma que compõe o sobrenome Kiyohara; Izumi é tirado do nome da região de onde o primeiro marido da autora foi governador. São mulheres sem identidade própria. Nesse sentido, há um salto de Kazuko: da menina Sarashina para a mulher que vai à luta.

Por isso, depois de ler o livro de Lênin tanto tempo depois, Kazuko acredita que "é mister que se faça uma revolução" (Cap. V) e diz: "Quero convencer-me de que o homem nasceu para o amor e para a revolução". ${ }^{34}$ Assim, tomou a decisão de seguir seu destino mediante uma mescla da mulher do Japão antigo e do que a encantou na leitura de Rosa Luxemburg: 
[...] a coragem desassombrada de ir destruindo, uma a uma, todas as velhas ideologias, sem nenhuma hesitação. [...] que mesmo contrariando de todas as maneiras os preceitos morais, fosse correndo, sem titubear e indiferente a tudo, para junto do seu amado. (Cap. V)

Kazuko adiara seu encontro com Uehara em função da doença da mãe, que acabou resultando em sua morte. Não havia mais o que protelar. Esse período de incubação serviu para ela ganhar mais força e coragem e confirmar sua determinação de buscar seu amor. Ela mostra-se realmente decidida a encontrá-lo, pois saiu apenas com algumas referências que conseguira de Naoji. Depois de passar na casa de Uehara e enfrentar sua esposa, que está com o marido ausente há vários dias e vivendo em péssimas condições, vai de bar em bar a sua procura, tendo que fazer e refazer caminhos.

Quando finalmente o encontrou, ela ficou na porta de entrada, observando-o:

Senti-me como um sonho. Estava diferente. Seis anos! Tornara-se uma pessoa completamente diferente.

Era este então o meu arco-íris, M. C., aquela pessoa que me fez viver? Seis anos! Os cabelos soltos continuam os mesmos de antigamente, mas estão tristemente ruivos e ralos; o rosto amarelecido e inchado; em torno dos olhos há irritações avermelhadas; está banguela; incessantemente, move e remove a boca. Parecia um velho macaco sentado com as costas arqueadas ao canto do quarto. (Cap. VI).

O homem que ela procura não é encantador. Vai se sentar ao lado dele na companhia dos que compartilhavam a mesma mesa e, ao brindarem com copos de saquê, o clima não era de comemoração.

E logo começa o coro: “Guillotine, guillotine, shur-shur-shur” (Cap. VI), que servia de compasso para o som dos copos brindando com força e virados de uma só vez garganta abaixo. Como explica a nota de tradução, "shur-shur-shur" é a onomatopéia imitando a queda da lâmina da guilhotina. E essa canção que Kazuko chama de absurda é cantada incessantemente a cada trago de bebida. Esses beberrões que escolheram como alternativa "grudar no Jiro Uehara e beber saquê até se

\footnotetext{
${ }^{34} \mathrm{O}$ itálico é do próprio texto em Pôr-do-Sol. Cap. V.
} 
esborrachar” (Cap. VI) são, na realidade os que fizeram a quarta opção, quando a primeira seria voltar à lavoura; a segunda, o suicídio; e a terceira, virar um rufião.

Observa-se que o coro é um enaltecimento ao símbolo da Revolução Francesa que decapitou os nobres. A respeito da guilhotina, encontramos em Kunō no Nenkan (Anuário de Sofrimento), escrito por Dazai em 1946: “[...] Todos os ricos são ruins. Apenas o povo sem dinheiro é correto. Eu apoiei o levante com as armas. Não há sentido numa revolução sem guilhotina".

Na visão do estudioso Komashaku Kimi:

Guilhotin, guilhotin, sur, sur, sur não expressa uma traição à classe social e nem a sensação de inferioridade. O símbolo da guilhotina, muito mais que um sentido de classe, tem um sentido de sofrimento fundamental da existência humana. $^{35}$

Podemos ver a duplicidade de sentido que ele carrega. Para os que desejam a cabeça dos nobres, uma revolução sem guilhotina não tem sentido. Por outro lado, para os nobres que foram destituídos no Japão, a guilhotina é o golpe de misericórdia, que abreviaria o sofrimento, conforme preconizou o médico francês Guillotin (1738-1814), nome do qual deriva esse instrumento.

A teoria da revolução de Dazai nada tinha a ver com o maxisimo ou o leninismo. A ditadura proletária era apenas uma novidade. "Um modo de pensar que se liga à lógica do diário de Naoji”, ${ }^{36}$ defende o estudioso Okiura Kazuteru. ${ }^{37}$

Uehara é um décadent, que confessa achar horrível o saquê, apesar de bebê-lo de manhã à noite, e que acha que chegou ao "crepúsculo da vida. O crepúsculo da arte. O crepúsculo da humanidade". E diz: "Em todo o mundo, tem-se a impressão de que caiu uma geada extemporânea" (Cap. VI).

Filho de lavradores do interior, Uehara diz detestar os nobres por serem arrogantes, e apesar da consideração que tem por Naoji acha difícil conviver com ele. Kazuko conta-lhe que agora ela também é uma pobretona do interior que lavra a terra em sua horta. Ao estar finalmente ao lado do homem no qual depositara tantas

\footnotetext{
${ }^{35}$ Kimi KOMASHAKU, Nihon Bungaku Kenkyū Shiryō Sōsho, Dazai Osamu, p. 43.

36 “A lógica, no final das contas, não passa de amor à lógica. Não amor ao homem." Pôr-do-Sol. Cap. III.

${ }^{37}$ Kazuteru OKIURA, Nihon Bungaku Kenkyū Shiryō Sōsho, Dazai Osamu, p. 3.
} 
esperanças, Uehara perguntou a Kazuko se ela ainda gostava dele e se queria um filho seu e a beija. Kazuko sentiu-se humilhada com a brutal demonstração do desejo sexual de Uehara e chorou, mas acabou se entregando a ele, na casa do pintor em que o escritor foi arrumar pernoite. Identificando o mesmo cheiro que sentia da mãe enferma, Kazuko perguntou a Uehara se ele estava tuberculoso. Confirmando, ele the revelou que ninguém sabia da doença:

- Bebo porque estou disposto a morrer. Não agüento a tristeza de estar vivo, entende? Solidão, soledade - não se trata dessas coisas de luxo. Apenas sinto-me triste. Quando se ouvem, aos quatro cantos, lúgubres suspiros de lamentações, não é possivel arranjar-se uma felicidade particular, só da gente. Quando se compreende que, enquanto está vivo, jamais se pode ter felicidade ou gloria próprios, que havemos de sentir? Esforço - isto apenas servirá de pasto às feras esfomeadas. Há gente miserável em excesso! (Cap. VI).

Uehara reconheceu que só o amor, o amor de que falava Kazuko na carta, traz a felicidade. Sobre esse amor, Kazuko não sabia o que escrever no final do primeiro capítulo, quando disse que "queria escrever tudo, claramente, sem ocultar coisa alguma”, concluindo: "Amor - escrevi, e notei que não conseguia escrever o resto". Esse amor que, quando amanhece junto a quem considerara seu amor, "tinha-se apagado" (Cap. VI). Mas o amor por quem ela chama de "meu arco-íris", "My Child", que estava ali diante dela, com o rosto de quem à beira da morte, fatigado e sacrificado, e ainda parece-lhe o mais belo de todos, ressurge como "Triste, triste realização do amor" e ela não quer mais se separar dele:

- Sou feliz agora. Apesar das lamentações que se ouvem aos quatro cantos. Esta minha felicidade acha-se no ponto de saturação. Sou feliz a ponto de espirrar.

Ele riu:

- Mas como já é tarde! Crepúsculo.

- É manhã. (Cap. VI).

Para Uehara, o sol está se pondo, não há mais esperanças, só resta esperar pela morte. Para ela, é o alvorecer, o raiar de uma nova vida, apesar da morte de Naoji, ocorrida no mesmo momento, e apesar de ser abandonada por Uehara, a quem considera uma vítima da "época de transformações morais" e que deveria "merecer 
dos pósteros alguma palavra de agradecimento". Foi ele quem lhe acendeu a chama da vida para, com o filho que traz no ventre, continuar a "lutar sem tréguas com a velha moral" na revolução que considera incompleta e que faz de suas vítimas o que há de mais belo no mundo em que ela vive.

Naoji renegou sua classe nobre, mas nem assim conseguiu misturar-se ao povo. É uma pessoa sem lugar no mundo, que recorreu às drogas e ao álcool para passear no mundo da fantasia e lá tentar encontrar a alegria e a vontade de viver que não consegue obter no mundo real, no qual também não consegue sobreviver. Decepcionado com as pessoas e com o mundo, a morte é o único caminho que lhe resta seguir, um direito que ele reclama para si como o direito que qualquer homem tem de viver. A morte significa estar livre da vida desagradável.

É estranha a observação de Yanagi Tomiko, que inclui como um dos motivos concretos que Trepliov tinha para cometer o suicídio o amor rejeitado por Nina, que seria o diferencial com Naoji, que morre sem um motivo palpável. Em seu testamento no último capítulo, temos a revelação que ele faz à irmã acerca de seu amor platônico por Suga, a esposa de um pintor amigo, ansiando por quem representa o amor honesto; ${ }^{38}$ é obrigado mergulhar na diversão com outras mulheres para tentar esquecê-la, mas em vão.

Não deixamos de admitir que a imagem do autor está presente em Naoji, mas salientamos que ela não é mera transposição. Naoji é um verdadeiro fracasso na profissão e no amor, a vida inteira:

Eu, que não passo de um capim, a custo vivo ao ar livre e ao sol desta vida. Para continuar vivendo, careço de algo em algum lugar. Algo me falta. Consegui viver até agora, e isso mesmo a muito custo.

Entrei no colégio e, ao defrontar-me pela primeira vez com amigos, fortes e rijos como plantas crescidas numa classe social completamente diferente daquela onde me criei, vi-me impelido pela força deles, mas, não querendo perder, tomei entorpecentes e resisti qual um louco. Depois, quando me tornei soldado, ainda ai me vali do ópio como último recurso para continuar a viver. Para a mana, acho, tudo isto deve ser incompreensivel.

\footnotetext{
${ }^{38} \mathrm{O}$ itálico é do próprio texto: Pôr-do-Sol. Cap. VII.
} 
Queria tornar-me deselegante. Queria ficar forte. Não, brutal. E pensei que este seria o único meio para me converter num igual do povo. [...]

Tornei-me deselegante. Passei a dizer palavrões. Entretanto, metade disso, não, sessenta por cento, não passava de pobre pretensão. Desastrados artificios! Para a turba, eu continuava sempre um homem constrangido, afetado e pretensiosamente composto. Ela não se digna de brincar comigo, abertamente. E todavia, já não posso regressar ao ambiente que abandonei. [...] Já não posso suportar, um segundo sequer, a elegância asquerosa da chamada alta roda. [...] Sem poder voltar à vida que reneguei, do povo só recebi um lugar no auditório cheio de maldade e solenemente idiota. [...]

Os homens são todos iguais. (Cap. VII)

Diz o estudioso Isogai Hideo que a busca do absoluto de Dazai não admitia o meio-termo - era a perfeição ou o nada - e que o autor não crescia, não se tornava adulto, porque não aceitava a relatividade das coisas. Sua revolta era com a falta de sensibilidade da sociedade e não com a estrutura social, e por isso ficava fora tanto do mundo aristocrático burguês como da massa popular. ${ }^{39}$ De fato, nas entrelinhas, as palavras de Naoji revelam essa natureza desconfortável e desesperada de Dazai.

As cartas que Kazuko escreve a Uehara não são inserções ilustrativas. Exercem mais do que uma função complementar, são elos entre as demais partes. Localizando-se exatamente no centro da obra, no quarto capítulo de um total de sete, elas desenvolvem o texto e encaminham-no para o desfecho: a decisão de viver unicamente pelo amor. É assim que ela se torna a sobrevivente dessa família de nobres decadentes: despojando-se da moral antiga, transgredindo as regras, indo à luta.

Cabe lembrar que na terceira carta é retomada a questão do "devasso" ("libertino"), ${ }^{40}$ quando Kazuko conversa com a mãe sobre a alegria que sente ao

\footnotetext{
${ }^{39}$ Hideo ISOGAI, Nihon Bungaku Kenkyū Shiryō Sōsho, Dazai Osamu, p. 13-4.

${ }^{40}$ Substituímos a tradução de "libertino" por "devasso", mas não por discordar da tradução de Antonio Nojiri, pois "devasso" tem acepções semelhantes à de libertino. Procuramos apenas fazer um uso distinto de "libertino", porque esse termo em japonês é empregado para denominar a corrente ou grupo no qual Dazai Osamu é classificado, ou seja, buraiha (no sentido de "vadio", "fora-da-lei"), ideogramas que recebem a leitura de riberutan (do francês libertin), pois em japonês o vocábulo correspondente é furyō.
} 
recordar-se dos elogios que recebeu, e ela, sem qualquer conexão lógica, perguntalhe:- Como é o professor de Naoji?

\section{Senti um calafrio.}

- Não o compreendo bem, mas deve ser um devasso (libertino) fichado, já que é mestre de Naoji.

- "Fichado" - murmurou ela, os olhos irradiando alegria.

- Que expressão divertida! Que ele seja fichado; então pode-se ficar mais tranqüila. Até chega a ser adorável, pois parece um gatinho com seu sino amarrado no pescoço. O que me dá medo é o devasso (libertino) sem ficha. (Cap. IV).

Nesse diálogo, que parece irracional, é como, se sem o saber, a mãe tivesse aprovado o amor de Kazuko, o segredo que ela disse possuir e pelo qual ela torcera que viesse a dar certo. Kazuko conta, na carta, a alegria que sentiu. Depois, afirma que gosta dos devassos (libertinos), especialmente dos fichados; que ela também deseja sê-lo e que, sendo ele o maior devasso (libertino) fichado do Japão, seu interesse por ele é ainda maior.

A palavra "devasso" ("libertino") é mencionada inicialmente no "Diário de Yūgao", de Naoji, sob a forma de indagação, como que justificando sua própria natureza: "Haveria alguém que não seja devasso (libertino)?" (Cap. III). Tempos depois, Kazuko imaginou se o irmão não seria mais feliz se acabasse por se tornar um devasso assumido (completo libertino), constatando ser também ela uma devassa (libertina), assim como o tio e a mãe. "Devasso" ("Libertino") - afinal, não quer dizer meiguice?" (Cap. III), concluiu ela.

A ligação de "devasso" ou mesmo de "libertino" com "meiguice" soa estranha em razão de uma aparente contradição que se vê entre essas palavras. No entanto, yasashisa, o correspondente a "meiguice", tem várias acepções em japonês, ${ }^{41}$ e em português ${ }^{42}$ também encontramos diversas acepções para meiguice, a

\footnotetext{
${ }^{41}$ Segundo o dicionário japonês Kōjien, da Editora Iwanami: ficar retraído, envergonhado; ficar diante de uma situação que é de um requinte constrangedor; ser obediente, condescendente, quieto, tímido, dócil, submisso, complacente; ser sensível, ter compaixão; excelente, ficar admirado com um santuário, um sermão; ter um sentimento de veneração, misterioso, sobrehumano.
} 
palavra utilizada na tradução. É possível verificar que, de alguma forma, “devasso" e "meiguice" cruzam-se no sentido de ser condescendente com seus próprios sentimentos, ser brando e não lutar contra eles.

É essa a natureza de Naoji revelada em seu diário. Naoji é capaz de escrever bem e levar o leitor à comoção, fazendo um romance perfeito, mas prefere deixar essa prepotência de lado:

Ah, as boas obras são justamente aquelas que não aparentam compostura. Eu, só pelo prazer de ver o rosto de meu amigo risonho de real alegria, falho de propósito na elaboração de um romance, escrevo desastradamente, e ponho-me em fuga aos tombos, coça-coçando a cabeça. Ah, o rosto feliz do amigo nessa ocasião!

Péssimo estilo, ordinária apresentação pessoal de quem fica a tocar corneta de brinquedo, eis aqui o maior burro do Japão; tu, entretanto, ainda tens salvação, sêfeliz - por que este meu amor ao próximo? (Cap. III).

Naoji quer ser gentil e amável com as pessoas e segue esse seu sentimento sem opor resistência, mas ao mesmo tempo não consegue se sentir confortável junto às pessoas e sujeita-se ao isolamento, na bebida e na diversão com mulheres, até que chega a seu limite:

Quando fingi precocidade, os homens comentaram que eu era precoce. Quando fingi preguiça, comentaram que eu era preguiçoso. Quando fingi não saber escrever romances, comentaram que eu não sabia escrevê-los. Quando me fingi mentiroso, comentaram que eu o era de fato. Quando me fingi rico, comentaram que eu era rico. Quando fingi insensivel, comentaram a minha insensibilidade. Mas, quando, sofrendo verdadeiramente, soltei um gemido sem querer, os homens comentaram que eu fingia sofrer.

De todo jeito, não dá certo.

Não é que a única solução para o caso é o suicídio?

Estou sofrendo. Só me resta o suicídio. Penso nisso, grito e choro. (Cap.

III)

${ }^{42}$ Pelo Dicionário Houaiss eletrônico, da Editora Objetiva: dotado de sentimentos gentis, ternos; carinhoso. Inspirado pela bondade, gentileza; afável, meigoso. Que causa impressão agradável; suave, ameno, brando. 
Naoji mostra seu lado gentil com as pessoas, de ficar na posição de servi-las, uma característica que Dazai manifestou em toda sua vida, ao lado da já comentada postura de se fazer passar por palhaço, mas nem assim conseguiu se aproximar das pessoas e viver bem com elas. A vida é pura frustração e sofrimento. Essas linhas escritas que Kazuko encontrou no diário de Naoji são apenas confirmadas no testamento que ele deixou antes de se suicidar, na manhã em que a irmã encontrou alento para viver. Diferentemente de Kazuko, que "é capaz de dizer o que pensa a quem quer que seja" (Cap. IV), Naoji só consegue revelar seus sentimentos por meio da escrita. As poucas e curtas falas dessa personagem no texto são tão diretas, irônicas, que chegam a ser agressivas. Quando volta da guerra, depois de tanto tempo fora de casa, vai entrando pelo portão dos fundos sem qualquer aviso, como se as circunstâncias que o levaram à separação da família fossem muito naturais, como se sua presença ali fosse extremamente normal. Cumprimentou a irmã com as palavras:

- Ué, horrivel! Que casa de mau gosto. "Mansão Chinesa”. "Temos shao-mai”. Bote isso numa tabuleta. (Cap. III).

O reencontro com a mãe nem nos é dado presenciar. Indagado por Kazuko sobre o que achara da mãe, ele disse:

- Mudou. Mudou. Mortificou-se. Devia morrer logo. Num mundo como este, alguém como ela não pode viver mais, de jeito nenhum. Tanta pena me dá que nem consigo ficar olhando para ela. (Cap. III).

De fato, ele mantevem distância o quanto pôde, até a morte da mãe, e isolouse da família e do mundo, afogando-se na bebida.

É por meio do Diário de Yūgao e do testamento que são lidos por Kazuko que conhecemos seus pensamentos e sentimentos, expressos de modo fragmentado mas tão incisivo quanto suas palavras presentes nos diálogos. A vida real equivale ao nada. A vida é sofrimento e ele busca a solução na morte.

A narrativa de Pôr-do-Sol, como foi visto, é intercalada não só por textos como o diário e o testamento de Naoji e as cartas de Kazuko, mas também por referências a obras literárias e religiosas, seja por seu título, pelo nome de suas personagens, citações ou menção de partes da obra que ampliam as esferas da narração por meio da intertextualidade, do dialogismo, criado por elas. 
Um fato curioso a ser registrado é que temos a voz feminina de Kazuko, um método utilizado por Dazai Osamu em outras obras, como Tōrō, Yuki no Yoru no Hanashi, Joseito e Villon no Tsuma, citadas pelo estudioso Yanagita Tomotsune ao tecer elogios ao autor, que "utiliza de forma habilidosa a forma confessional feminina, adequando a narração de suas personagens de acordo com a faixa etária e a natureza da personagem"43.

Pelas datas de Tōrō (Lamparina, 1937), Yuki no Yoru no Hanashi (História de uma Noite de Neve), Joseito (A Estudante, 1939 ) e Villon no Tsuma (A Esposa de Villon, 1947), observamos que Pôr-do-Sol é a última de uma série de obras na qual ele emprega a voz narrativa feminina, mas podemos dizer que, como demonstrado em várias passagens da estruturação e montagem dessa obra, sua forma narrativa apresenta um elevado grau de apuração, que alude ao método empregado na obra Tosa Nikki (Diário de Tosa), ${ }^{44}$ a primeira obra em voz feminina na literatura japonesa, escrita em 935 por Ki no Tsurayuki (870-945), um dos antologistas da Kokin Wakashū (Coletânea de Poemas de Outrora e Hoje, 905), a primeira das 21 editadas por ordem imperial ${ }^{45}$ no período clássico.

Renomado poeta da corte, Ki no Tsurayuki compôs um grande número de poemas, mais de 300 constando de coletâneas editadas por ordem imperial. Essa obra inaugurou o novo gênero conhecido como nikki (diários), utilizado principalmente pelas damas da corte, que criaram um período de glória da literatura feminina japonesa já mencionada. Narra a viagem de Tsurayuki e sua comitiva de retorno à capital Quioto, depois de cumprido o mandato como Governador de Tosa, atual Província de Kōchi, de onde partiu em 21 de dezembro de 934.

Tsurayuki foi inovador ao parodiar os diários burocráticos escritos em chinês, denominados niki, e criar um diário poético que abandonou os ideogramas e empregou a voz narrativa feminina como disfarce para justificar essa obra inovadora escrita com os fonogramas hiragana, utilizada, no início, exclusivamente pelas mulheres. Ao mesmo tempo, encenou a vontade das mulheres da época de imitar os homens em seus diários oficiais, registrando os 55 dias de viagem com inserções

${ }^{43}$ Tomotsune YANAGITA. Nihon Bungaku Kenkyū Shiryō Sōsho, Dazai Osamu, p.217.
${ }^{44}$ V. Apêndice, p. 18-19. 
introdutórias e explicativas sobre os poemas supostamente compostos em momentos memoráveis, do início ao fim da viagem. ${ }^{46}$

Em Pôr-do-Sol, enxergamos uma intenção semelhante de Dazai de tornar Kazuko a porta-voz dessa história em que ela é a única sobrevivente do mundo japonês em transformação após a Segunda Guerra Mundial. Dazai cria essa narradora-protagonista, que não deixa de ser uma de suas faces em interação com suas outras faces, que são a mãe, o irmão mais novo e o amante.

Já em Villon no Tsuma, por exemplo, temos uma narradora construída de maneira secundária, na figura de Sachiko como esposa de Otani, um escritor que se ausenta por vários dias seguidos de casa às voltas com mulheres e bebida, deixando-a com o filho deficiente mental passando necessidades. Ela é semelhante aos protagonistas das obras analisadas no capítulo anterior, uma mulher submissa que, apesar de tudo, se importa com o marido e se sujeita ao trabalho pesado para pagar as dívidas dele, sem, contudo, pensar que se trata de um sofrimento ou sacrifício. Como personagem, é o retrato da mulher dedicada que ama incondicionalmente, e observamos nisso uma intenção de criar uma figura ideal. Em termos de elaboração, porém, a obra limita-se a narrar os fatos de modo linear e sem a inserção de elementos que contribuem para seu enriquecimento, como é o caso de Pôr-do-Sol.

Sustentado pelo irmão mais velho até o final da guerra, Dazai mantém-se como um jovem cheio de orgulho e muito sensível, o que normalmente não é viável quando se precisa enfrentar a necessidade do dia-a-dia e batalhar pelo próprio sustento. Dazai não se sente confortável com sua própria condição de descendente da nobreza rural quando começa a ter contato com o comunismo, por volta de 1926, época em que freqüentava o colegial. Essa relação foi mantida na faculdade e depois dela, até meados de 1932. Depois da união com Oyama Hatsuyo, em fevereiro de 1931, logo após sua primeira tentativa de suicídio com uma garçonete, que acaba morrendo na ocasião, os movimentos ilegais de Dazai mudam. Ele despista a polícia com sua vida de cidadão comum, mas oferece a casa como ponto de agitação, local de reunião; por isso, foi detido diversas vezes. Em 1935, faz a segunda tentativa de

\footnotetext{
${ }^{45}$ V. Apêndice, p. 15 .
} 
suicídio. Quando ingressa no curso de Francês da Universidade de Tóquio, chega a fazer panfletagem, e correm boatos de que ele era filiado ao partido comunista, mas não se sabe ao certo até que ponto ele fazia parte do movimento. Ele se identificou com o comunismo por achar que travava a mesma luta com a realidade, mas não por ideologia.

Dazai viveu um período de grande repressão ideológica, que se intensificou a partir do golpe militar de 26 de fevereiro de 1936, quando foi reformulada e promulgada a lei de proteção e observação contra os crimes ideológicos e a vida econômica da população passou a ser controlada. Com o confronto das tropas japonesas e chinesas na noite de 7 de julho de 1937 na Ponte Marco Pólo próximo a Pequim, teve início a guerra do Japão contra a China. Ao contrário da solução rápida que era divulgada, a guerra só intensificava-se. Novas perseguições ideológicas se repetiram, com o intuito de unificar o pensamento dentro do país, e as prisões se multiplicavam.

Ao mesmo tempo, as revistas foram alvo de censura, sofrendo apreensões e proibições de venda. Em abril de 1938, foi promulgada a lei de mobilização nacional, sendo concluídos os preparativos para situação de guerra em todos os setores da vida da população. Em 1939, foi lançada a diretriz para mobilizar o povo diante da guerra e promulgada a lei de controle de distribuição de arroz. A grande derrota para a Rússia em setembro de 1939 numa batalha iniciada desde maio na região de Nomonhan foi mantida em segredo. Em julho de 1939 foi promulgada a lei para convocação da população para a guerra e o Japão entrou no sistema de mobilização do povo também para prestar serviços em geral. Além dessas pressões provenientes do poder político, os círculos literários e o mundo jornalístico também sofreram represálias desde o período áureo do marxismo nos anos de 1926, com o poder que obrigava os profissionais a abandonarem suas ideologias, as acusações sobre aqueles que se manifestavam de modo liberal, acrescidas pelas denúncias anônimas que chegavam às instâncias que cuidavam do controle de pensamento.

\footnotetext{
${ }^{46}$ Neide H. NAGAE, O Surgimento do Diário como Obra Literária na Literatura Clássica Japonesa, p. 93.
} 
À medida que a Segunda Guerra Mundial foi se intensificando, Dazai se tornou mais dócil. Em Shishin (Minhas Crenças, 1941), explana que procurou seguir seus sentimentos e viver de modo reto, simples, para aproveitar cada dia da melhor maneira possível ante a ameaça da destruição; em Ichimon Ichitō (Resposta para uma pergunta, 1942), declara:

Nos últimos tempos, sinto ainda mais que o ser humano precisa ser honesto. [...] A vida torna-se dificil e complicada porque as pessoas tentam usar de subterfúgios. Se formos honestos no que dizemos e no que fazemos, a vida torna-se muito simples. [...] Ter desprendimento também é importante. ${ }^{47}$

Esse sentimento de Dazai, presente, por exemplo, em Fugaku Hyakkei, abordado no capítulo anterior, parece estar latente em Pôr-do-Sol, que, segundo o estudioso Watabe Yoshinori ${ }^{48}$, foi criado a partir da simplicidade, retidão e sinceridade consigo mesmo, presentes em suas obras, alicerçadas no amor e na beleza do sentimento humano. Esse espírito se manifestou de modo mais acentuado nas obras de 1939 a 1940 e foi mantido em novo formato em obras como Otogizōshi. Em Pandora no Hako, os mesmo elementos surgiram como a imagem do ser humano ideal, perseguida durante longos anos por Dazai, mas é esmagada pela podridão da sociedade, ressurgindo depois em Pôr-do-Sol de maneira exemplar.

De acordo com Yoshinori, as quatro personagens também são partes de Dazai. Uehara mostra seu lado mundano, é um beberrão mulherengo, inseguro e desleixado, que vive uma vida decadente, mas não sofre porque é narrado com a devida distância, de modo objetivo. Naoji, na visão do estudioso, é o porta-estandarte do sofrimento, uma personagem que carrega o ideal de derrota de Dazai numa busca desenfreada pelo que é o verdadeiro amor e o verdadeiro ser humano; critica o mundo torturando a si mesmo mental e fisicamente, e vai derrubando tudo que é mundano. Incompreendido pelo mundo, continua a vida decadente e solitária até se matar.

A Mãe é o contraponto de Naoji, diz Yoshinori. Ela concretiza a imagem do ser ideal que abandonou a vida e a ambição e que se encontra no estado de

\footnotetext{
${ }^{47}$ Yoshinori WATABE, Op. cit., p. 53.

${ }^{48}$ Ibidem, p. 65.
} 
"resignação santa", 49 desprovido de "orgulho" e de "ostentação". Naoji e a mãe são a imagem de ser ideal: ela representa o lado positivo; ele, o negativo. No entanto, ambos morrem, e Kazuko nasce a partir da fusão dessa imagem idealizada do positivo e do negativo, revestida com as qualidades de cada um deles: a Kazuko dotada da sinceridade, alegria e meiguice da mãe, e que inicia a luta na segunda parte do romance; após a morte da mãe, mostra as características de Naoji, que tenta lutar contra os valores mundanos em prol da revolução do amor e da moral.

A imagem ideal da mãe e de Naoji, conforme Yoshinori, não teriam nenhuma chance no mundo real, e somente Kazuko, que os utiliza como trampolim, pode ter forças para viver. Por isso, o estudioso afirma que Kazuko é a imagem ideal do ser humano que Dazai preconizou e não conseguiu concretizar em Pandora no Hako. É a nova imagem do ser humano tão ansiado por Dazai, mas que ele não conseguiu encontrar na sociedade japonesa do pós-guerra. Essa imagem do ser humano e também de uma sociedade repleta de pessoas como ela é alcançada em Pôr-do-Sol, mas, como mostra o título, ela é, segundo Yoshinori, a beleza do ocaso do astro rei flamejante que é Dazai e estava fadada a se apagar pouco depois.

Com a criação das personagens de Pôr-do-Sol, Dazai Osamu vai além dos protagonistas dos romances do Eu vistos como formas de revelação de seus próprios autores em suas respectivas obras, sejam eles narradores-protagonistas ou protagonistas narrados e que, como mostramos no Capítulo II deste estudo, não são os esperados narcisistas em nenhum momento, e compartilham de uma natureza passiva e resignada diante de suas dificuldades e de seus sofrimentos, resultantes mais do contexto social e político, do que familiar. Essas obras não transmitem simplesmente o que o autor sente relatando acontecimentos ligados a sua vida e menos ainda constituem pura confissão.

Nossa visão a respeito das quatro personagens de Pôr-do-Sol assemelha-se à de Yoshinori em alguns aspectos, mas difere em relação a vários pontos que resultam numa interpretação diferente no conjunto. Para nós, a Mãe seria o pólo positivo, como diz o estudioso, mas não como pólo oposto de Naoji. Vemos Naoji como pólo

\footnotetext{
${ }^{49}$ Esse termo também é utilizado por Tōgō Katsumi em sua análise sobre o Otogizōshi, citada anteriormente.
} 
negativo em relação ao positivo que é Kazuko, e os dois estariam nos dois extremos de uma linha horizontal, ou melhor, Naoji em algum ponto negativo e Kazuko em outro ponto positivo de uma ordenada X; a Mãe, por sua vez, estaria em algum ponto positivo de uma coordenada $\mathrm{Y}$ e Uehara, em algum ponto negativo dessa linha vertical. Dazai Osamu, o autor, seria a totalidade desse gráfico XY, isto é, estaria em todos os pontos dos quatro quadrantes de uma circunferência que se funde com a representação do mundo, do globo terrestre, com seus quatro pontos cardeais principais - principais porque são limitadas em número, mas permitem infinitas possibilidades.

Em nossa cruz, assim formada pelas quatro personagens-símbolo, a Mãe, com todas as características de pureza, amor e simplicidade sem ostentação, expressa pela "resignação santa", representa a nobreza japonesa em extinção em algum ponto do pólo positivo da linha vertical, uma vez que os nobres poderiam estar acima, abaixo, à esquerda ou à direita, em qualquer um dos pontos, de acordo com suas respectivas naturezas. Uehara, filho de lavradores, representa a camada popular japonesa, no pólo negativo da mesma linha da Mãe, valendo para ele as observações já feitas a respeito do lugar ocupado pela personagem. Naoji e Kazuko representam uma nova geração descendente de nobres em transformação. Naoji tenta ocupar seu espaço junto às camadas populares, mas não consegue defini-lo; no testamento, diz ser um nobre, sem um lugar no mundo, e opta pela morte. Kazuko é aquela que herda traços da mãe e do irmão e não teme as transformações; luta pela revolução e pelo amor e opta pela vida. Ela dará origem à imagem ideal do ser humano sonhada por Dazai.

Nesse cruzamento $^{50}$, inserimos Uehara, representante do povo, no pólo negativo da coordenada $\mathrm{Y}$ por sua origem rural ligada à terra, no oposto da Mãe, que se liga à elite, considerada superior nas relações hierárquicas, mas também por ser descrita como uma imagem sublime - em termos dos pontos cardeais, o Norte tradicionalmente se impõe como superior ao Sul, onde se situa Uehara. Naoji, como pólo negativo, está no Oeste, o poente. A ele só restam átimos de existência visível. Kazuko, no Leste, tem a positividade a seu favor. Começa a tornar-se visível e será iluminada pelo radiante calor do sol. Cada qual em sua posição, segue seu próprio 
sentimento, sem opor resistência, o que significa que cada um e todos têm o direito de fazer sua escolha. Isso liga-se ao anarquismo, mas ao mesmo tempo à liberdade.

Dazai reconhece o respeito ao direito de cada ser humano fazer sua própria opção, como mostra Pôr-do-Sol. Situadas como pares de opostos nas ordenadas e coordenadas, as personagens dialogam entre si e ampliam o diálogo de Dazai consigo mesmo, que simbolicamente não ocupa nenhum lugar dessa circunferência traçada pelas quatro personagens, mas existe como essência de todas elas e está em todos os quadrantes como possibilidade de cruzamentos infinitos. Ao alojar a semente de Uehara em seu ventre, Kazuko dará à luz um herdeiro híbrido, resultado de uma mutação de sua origem nobre e da origem profana de Uehara. É por isso que Kazuko diz, em sua última carta a Uehara:

penso ter rechaçado a velha mora, ainda que em diminuta proporção, na primeira batalha desenvolvida até agora. E estou com intenção de me acometer à segunda e à terceira lutas com a criança que agora vai nascer.

O fato de dar à luz o filho de uma pessoa amada e de criá-lo constitui o coroamento da minha própria revolução moral. [...] Quem passou em meu peito o arco-íris da revolução foi o senhor. Quem também me deu a motivação para viver. [...] a revolução ainda não está, de modo algum, completa. Parece-me que serão necessárias mais e mais vítimas nobres a lamentar.

No mundo atual, o que há de mais belo são as suas vítimas. (Cap. VIII).

A criança, sim, é a imagem do homem ideal que Kazuko irá dar à luz, e terá "uma vida radiosa como o sol".

Sendo Kazuko, a narradora-protagonista da obra, podemos dizer que a começar pelas obras O Jardim das Cerejeiras e A Gaivota, de Tchékhov, Pôr-do-Sol dialoga com Fausto e Sarashina Nikki para sugerir aspectos que fazem parte da natureza das personagens e insere citações de muitas outras, de autores como Fausto, Byron, Rosa Luxemburg e Turguéniev, assim como várias passagens da Bíblia e crendices populares reveladoras dos pensamentos e tendências que movem as personagens em cada situação. Man'yōshū e Genji Monogatari são exemplos de mais

\footnotetext{
${ }^{50}$ Mokiti OKADA, O que é limite, p. 472.
} 
obras que remetem a contextos de outras épocas a fim de serem reconsiderados e comparados com o momento histórico retratado na obra.

Nessa malha de textos de Dazai emergem registros das próprias personagens, nas formas de diário, carta e testamento. O diário e o testamento de Naoji servem como material informativo sobre alguém que não consegue interagir com as pessoas e ser compreendido por elas. Seus memorandos são, em sua maioria, momentos tristes de registros de insatisfações, lembranças desagradáveis e deprimentes, desejos frustrados, manifestações de revolta e desespero diante da situação vivida. Ao revelar esse lado negro da vida, Dazai trabalha como Tchékhov. Compõe uma comédia. A postura palhaça de Dazai aparece aqui, não pelos gracejos que ele fazia para conseguir se socializar, mas por meio da escrita imitativa baixa. Ele não vê a autoconfissão como forma de salvação, mas como alvo do riso.

As cartas de Kazuko posicionadas no centro dos demais capítulos assumem múltipla função como cerne da obra, unindo também conteúdo e forma. Além de declarar seu interesse por Uehara e seus propósitos, atualiza a informação do leitor sobre acontecimentos relativos ao irmão, à Mãe e a ela mesma, sem interromper o desenvolvimento da narrativa. É nelas que grande parte da intertextualidade da obra se faz presente.

Vemos, portanto, que Pôr-do-Sol emana raios de luz, resultantes do entrelaçamento dos fios narrativos de que é tecido, e esses raios de luz não são fortes e ofuscantes a ponto de cegarem os olhos; são antes uma luz visível, como o são as obras escolhidas para tecerem sua narrativa. Nesse aspecto, a estrutura desta obra vai além da linearidade geralmente encontrada nos Romances do Eu estudados no capítulo anterior. Não só, o uso recorrente de elementos de intertextualidade reforça o caráter lietário da obra com o intuito de desvincular a realidade ficcional da realidade factual.

Nessa obra, Dazai revela que o romance não permite o monólogo genérico, mostra que há um diálogo entre os textos admitidos pelo sistema canônico literário e os que não se inserem nele como os diários, os textos religiosos e qualquer forma de expressão inscrita em qualquer cultura de qualquer sociedade. 
Ainda que aponte para a esperança, para a realização do sonho na concretização da imagem do ser humano ideal, a obra reveste-se de uma tristeza profunda, e o título acentua essa sensação.

Depois de Pôr-do-Sol concluiu mais duas obras: Ōtō (Cereja, 1948) e Ningen Shikkaku (Ser Humano Desqualificado, 1948), esta última uma espécie de testamento ou auto-retrato que escreveu consciente de que sua vida não iria durar muito. Já tuberculoso e castigado pela insônia e pelo cansaço devido ao excesso de trabalho e o desgaste físico com a bebida, o autor, sem terminar de escrever a cômica obra Guddobai (Adeus), suicidou-se ${ }^{51}$ jogando-se nas águas do Rio Tamagawa em Tóquio no dia 13 de junho de 1948, como se tivesse mergulhado em busca da pepita de ouro no fundo do rio ou do Templo do Dragão que Urashima encontrou no fundo do mar. Misteriosamente, seu corpo só foi encontrado no dia 19 de junho, ${ }^{52}$ data de seu $39^{\circ}$ aniversário.

\footnotetext{
${ }^{51}$ Anteriormente, Dazai havia feito três tentativas de suicídio. Em 1930, no mar de Kamakura onde se joga com uma garçonete que morre na ocasião; em 1935 nas matas de Kamakura onde tentou enforcar-se e em 1937, depois de ter descoberto que fora traído por Oyama Hatsuyo enquanto esteve internado nas termas de Tanikawa em 1936 para cuidar da dependência de morfina e da tuberculose nas termas de Minakawa em 1936. Hatsuyo morava com ele há seis anos, desde que ele a fizera deixar o trabalho de gueixa.

${ }^{52}$ No primeiro ano de seu falecimento, foi realizado um encontro em sua memória diante de seu sepulcro e desde então, é realizado anualmente sob o nome de Cerimônia Ōtō.
} 


\section{CONCLUSÃO}

Nos primórdios da formação da literatura a herança chinesa inspirou os gêneros e formas da poesia. A prosa iniciou-se com os diários, as narrativas, os setsuwa ${ }^{1}$ e os ensaios, sobretudo depois da criação da escrita fonogramática, que facilitou a expressão escrita dos japoneses. Essa configuração permaneceu até o isolamento japonês, ocasião em que surgiram novos gêneros de grande popularidade, os quais deram lugar a uma literatura de entretenimento baseada na moral confucionista, mas asseguraram a continuidade da composição de poemas em chinês e o estudo da literatura chinesa.

Com a abertura para o Ocidente, as formas literárias assumem outra "roupagem". O estilo ocidental invade aos poucos a arte literária do período anterior, até constituir nova divisão, em que prevalece a prosa constituída por diversos tipos de romances. Na poesia, permanecem os poemas japoneses e chineses e passam a ser produzidos os poemas $s h i$, que seguem a forma ocidental.

Terminado o período de publicação das últimas obras que representavam o período anterior, começa o período de "iluminação", com traduções de obras ocidentais que promovem a divulgação da cultura ocidental e os romances traduzidos. Surgem publicações das modernas concepções ocidentais produzidas pelos próprios japoneses que foram estudar na Europa e nos Estados Unidos, e uma variedade de romances políticos (seiji), de idéias (kannen), trágicos (hisan), românticos, idealistas e de costumes (füzoku) são produzidos. Formam-se círculos literários, como a Kenyūsha, de Ozaki Kōyō, e posteriormente grupos de escritores e poetas reunidos em revistas literárias, que começam a assumir o formato de círculos literários. O Romance do Eu surgiu nesse contexto. Do ponto de vista filosófico e "ideológicos", no entanto, o que se manteve foi o espírito japonês, que institui o xintoísmo como religião oficial.

\footnotetext{
${ }^{1}$ A chamada Narrativa Setsuwa é formada por pequenos episódios budistas ou seculares e que tem Nihon Ryōiki (Os Relatos Milagrosos do Japão), da autoria do bonzo Kyōkai, como a primeira do gênero, surgida por volta de 824, e várias obras até o início do século XIV. V. Apêndice, p. 26-28.
} 
O espírito japonês se manteve desde os primórdios da cultura japonesa, mas o conhecimento chinês que o acompanhava foi substituído pelo conhecimento ocidental. Se considerarmos que mesmo no período do isolamento os meios literários ainda idolatravam os poemas e textos chineses, podemos dizer que a mudança radical se dá efetivamente com a introdução das novas influências da literatura ocidental. Tais influências, contudo, não são absorvidas de imediato e muito menos de modo integral; sofrem adaptações, como ocorreu com a cultura chinesa, introduzida nos primórdios da história do Japão.

Surgido numa época em que o Japão acabara de abrir os portos ao Ocidente, quando, então, entraram simultaneamente o Romantismo e o Naturalismo, o Romance do $\mathrm{Eu}$, de caráter autobiográfico, nasce como os romances biográficos e autobiográficos, que, assim como o romance de formação, são, segundo Bakhtin, produtos do século XVIII.

Pode-se dizer que é um gênero híbrido, resultante desse novo contexto literário, de novas idéias que se fundem ao que já existia no mundo literário japonês, moldado pelas contingências sociais e políticas da época em que o Romance do Eu surgiu e veio a se desenvolver. Sua fama de romance escrito por autores alienados da sociedade tem uma razão de ser, e ele pode ser visto como um subterfúgio, uma camuflagem.

Não seria exagero, portanto, afirmar que o Romance do Eu é resultante da repressão ideológica e política, já que, ao fazer uma contestação contra o regime vigente, os autores o fizeram de maneira velada, nas entrelinhas do texto. Nas primeiras obras, foi possível observar que essa forma literária centrada na vida pessoal do autor é também um fenômeno de repressão social, no nível das relações amorosas, pela modificação no pensamento que rege o casamento, a família, as convenções sociais.

Escritores desse período inicial do contato com o Ocidente e, por extensão, da transformação de valores de todo um povo e de toda uma cultura manifestam, em sua produção literária, aspectos shōjo (modo menor, hinayana, do budismo). Olham para suas angústias, seus sofrimentos, seus sentimentos agravados por uma discordância com a política nacional, fazendo parecer "uma falta de interesse ou de 
compromisso", uma alienação do mundo do qual deveriam fazem parte. Contudo, esse contestar no nível individual, que afeta o cotidiano de uma pessoa, de um cidadão, revela-se uma forma de dizer "não" a todas as mudanças que influenciaram diretamente a vida do povo. É quase uma doença, sintoma de um mal que acomete a sociedade intelectual. Eles se negam a pensar?

Como já mencionado, a repressão ao livre pensamento foi muito intenso no Japão. Os líderes das novas religiões desse período foram tão reprimidos quanto os cristãos, que "abandonavam" a fé ou morriam, no período em que o Japão começou a se fechar para o Ocidente, no governo militar do século XVI. Essa situação não foi diferente para os escritores. A liberdade de pensamento e de expressão só foi obtida após o término da Segunda Guerra Mundial. Não é possível que nada disso tenha deixado de influenciar essa classe pensante. Só resta admitir que ela tenha sido obrigada a ser submissa, pelo menos na aparência. Isso aconteceu em várias fases da história do Japão: a força bruta e tirana do governo sobrepondo-se, impondo-se ao povo. Mesmo quando a assim chamada literatura do proletariado, baseada em idéias socialistas, surge, ganhando força no cenário nacional, os escritores são obrigados em seguida a retratar-se, e a maioria deles passa a escrever Romances do Eu.

Nota-se, nesse gênero, que a escolha do foco narrativo em terceira pessoa é menos comprometedora. Ao passar para o discurso indireto livre, o narrador assume os atos e sentimentos do personagem principal, mas sempre será uma terceira pessoa e não a primeira pessoa, o autor. O Romance do Eu é uma tentativa de enxergar-se a si mesmo, pois cada um enxerga o que está ao alcance de sua visão sem, contudo, enxergar o que o outro vê.

O Romance do Eu, no entanto, não é puro monologismo. Dialoga com seus pares, que estão em consonância com os sentimentos do protagonista, pessoa acuada e sem poder de ação, porque é reprimida e tolhida. Parodia as obras estrangeiras européias que entram no Japão, mas insere o que há de mais inato no japonês, seu próprio eu, a tradição dos ensaios, diários e o lirismo poético.

O enredo do Romance do Eu é um fragmento da vida cotidiana. Focaliza os acontecimentos de um determinado período, que pode ser curto, como o da crônica, ou mais longo, para dar conta da duração do evento ou fato que se quer relatar: 
situações que a vida impõe com as circunstâncias, conseqüências de ações do sentimento, muito mais do que da razão. Pode ser de qualquer período da vida, infância, juventude, meia-idade ou velhice, mas com menor freqüência sobre a infância e a tenra juventude, pois, em geral, as narrativas abordam um passado quase imediato ao da escrita. Não há começo, meio e fim muito definido. O que há é um recorte do conteúdo que se pretende expor.

O mundo em volta e as personagens secundárias muitas vezes transformam-se em pano de fundo para a personagem central. O protagonista fala de si mesmo, de fatos que o cercam no cotidiano, na vida privada. Nota-se uma dificuldade de sair dessa esfera particular, familiar, e de se expressar sobre o alheio, sobre o mundo em que vive. Encontramos, no oculto background do protagonista e das personagens, o que fica evidente por esse modo ensimesmado de se expor ao mundo. Não há espaço para que o autor fale de outros assuntos além daqueles que pertencem à esfera de sua intimidade; quando esse espaço parece existir, o autor prefere restringir o relato a fatos passados, de uma narrativa em terceira pessoa, de um protagonista criado com nome e sobrenome para manter o distanciamento.

Encontramos, nas obras, um testemunho da realidade às avessas; revelar, mantendo-se calado; mostrar sua vida particular, a de um pequeno círculo de amigos, para não mostrar a vida do povo; restringir-se aos assuntos da família, para não tocar nos assuntos coletivos; denunciar, sem nada declarar. A crítica social àquele mundo em transformação, no qual os próprios escritores iniciam sua ascensão, ocorre subliminarmente. Os dados que encontramos nas páginas da narrativa não nos permitem de fato identificar o protagonista com o próprio autor, embora esse elemento de indissociabilidade entre a vida real do escritor e a sua representação literária tenha sido cultivado pelos círculos literários da época, se isso pudesse conferir mais credibilidade à narrativa e acentua sua verossimilhança.

As obras do Romance do Eu normalmente são curtas em extensão e em tempo da narrativa. As mais curtas assemelham-se às crônicas e aos contos. Algumas obras fazem um registro preciso das datas em tempo histórico, seguindo uma ordem cronológica, mas a maioria trabalha o tempo da narrativa de modo criativo, ora iniciando pelo desfecho, ora dando a impressão de que estamos acompanhando a 
escrita, ora à mercê do vaivém temporal da narração, e situa a narrativa sem grande distanciamento temporal da escrita da obra. Por isso, retrata o momento histórico contemporâneo de modo sincrônico.

O espaço privilegiado do Romance do Eu é o urbano, da atualidade - no caso, Tóquio, capital do Japão, localizada no leste do país, e outros centros, como Quioto e Osaka, na região oeste. Quando o espaço é instaurado num lugar distante desses centros, está implícito que esse é um lugar ao qual um escritor radicado na cidade é levado pelas circunstâncias. Vemos, ainda, que a cidade é o grande centro da vida literária, o local procurado pelos aspirantes à carreira. A cidade em processo de ocidentalização, os trens, um dos grandes marcos da modernização do Japão, tudo é focalizado com muitos exemplos concretos presentes na vida das personagens, e esse foco, que é mais nítido nas obras iniciais, vai-se diluído nas mais recentes - o que era japonês vai ficando cada vez mais para trás, mas continua presente no cotidiano.

As transformações sociais e culturais decorrentes do processo de ocidentalização levam os escritores a uma séria de indagações a respeito da própria identidade e de seu papel na nova sociedade em formação. As peregrinações em busca do "eu verdadeiro", constituem, grosso modo, um ritual de passagem presente nesse tipo de narrativa. Nessa atitude, enxergamos um costume cultivado desde os tempos antigos por várias pessoas, a começar pelos imperadores, o chamado shukke, ou seja, abandonar o convívio com a família e a sociedade depois de certa idade, optando pela vida voltada ao aprimoramento espiritual em algum templo, ou na reclusão, como fizeram os famosos bonzos Kamono Chōmei e Yoshida Kenkō, autores dos ensaios budistas Hōjōki e Tsurezuregusa $a^{2}$.

Assim, poderiam assemelhar-se às personagens do romance de viagens, que, segundo Bakhtin, "é um ponto que se movimenta no espaço, ponto esse que não possui características essenciais nem se encontra por si mesmo no centro da atenção

\footnotetext{
${ }^{2}$ Conhecida como zuihitsu, essa forma literária foi iniciada no século XI e ganhou maior expressão a partir do século XIII com essas duas obras, respectivamente, de 1212 e 1331, que discorrem sobre a efemeridade, mas a primeira lamenta a inconstância deste mundo, e a segunda valoriza a inconstância e a diversidade. V. Apêndice, p.17-18.
} 
artística do romancista", ${ }^{3}$ mas distingue-se dele porque não "tem como característica uma concepção puramente espacial e estática da diversidade do mundo". 4

Da mesma forma, algumas personagens do Romance do Eu alcançam a satisfação não encontrada na vida real, levados a reflexões existenciais, principalmente por meio da observação e do contato com a natureza, enquanto estão à espera de uma definição sobre o futuro. Outras não são capazes de enfrentar o mundo real, pois este não lhes dá alternativas senão manterem-se em segundo plano, como é o caso das obras com teor laudatório a outrem ou que mostram a autoflagelação. Os dois tipos de protagonistas continuam dependentes, à mercê dos acontecimentos, e não apresentam uma mudança. Como mostra Bakhtin sobre as peculiaridades das modalidades de construção biográfica, ele "continua essencialmente inalterado"; a narrativa "se concentra nos afazeres", que apresentam os infortúnios vividos, a crise mencionada por Bakhtin, mas sem o renascimento ${ }^{6}$ no sentido positivo, pois a marca comum do Romance do Eu é que existe a crise, mas não o renascimento para as personagens.

As obras narram a aparência, tatemae, sem deixar de mostrar o sentimento verdadeiro que vai no íntimo, honne. Os que conseguem um equilíbrio, ou algo próximo ao equilíbrio em suas vidas, mantendo as aparências, sobrevivem - apenas sobrevivem; não alcançam a notoriedade nem o sucesso artístico, a satisfação individual em termos profissionais ou familiares. São epicuristas, na maior parte das vezes.

Os heróis não são originários da nobreza. Muitos são do interior, e os que já possuíam posição social privilegiada são igualmente submissos e resignados. São protagonistas do Japão moderno na pele de um artista. O fechamento em si mesmo das personagens, e também o de seus autores, é um "suicídio em vida", num Japão que não oferece oportunidades de inserção social, com as intermináveis e sucessivas guerras, realizadas em nome da soberania e do crescimento do país, contra a China, entre 1894 e 1895, e contra a Rússia, entre 1904 e 1905, seguidas pela Primeira

\footnotetext{
${ }^{3}$ BAKHTIN, Mikhail. Estética da Criação Verbal, p. 205.

${ }^{4}$ Idem, p. 206.

${ }^{5}$ Idem, p. 215

${ }^{6}$ Idem, p. 214.
} 
Guerra Mundial, pela invasão japonesa ao continente chinês e pela criação do Império da Manchúria, até chegar na Segunda Guerra Mundial. Essas identificações com a localização histórica definida se fazem presentes de modo sutil nas obras do Romance do Eu. O presente não é a bem-aventurança, a felicidade está sempre por vir. Por isso, as personagens não são impressionantes por suas virtudes e feitos grandiosos, mas por suas fraquezas e insucessos.

Em Pôr-do-Sol, o autor utiliza a voz feminina para narrar a ruína da nobreza imediatamente após a guerra, por meio de personagens que podem ser vistas como seu desdobramento, cada qual com peculiaridades que se complementam e interagem entre si e cujas características são ampliadas por uma intertextualidade variada que abrange obras japonesas e estrangeiras. O texto de Dazai dialoga com essas obras, e as personagens dialogam entre si. $\mathrm{O}$ autor dialoga com ele mesmo nas quatro personagens principais como imagens representativas de seu desdobramento, formando pares de oposição, como vimos no Capítulo III, conforme a ilustração abaixo, à esquerda.

Se interpretarmos a cruz mediante expressões como enten katsudatsu "movimento giratório sem obstruções" - e rinne tensho - "vida que muda de lugar de modo cíclico" -, o modelo pode ser ampliado para a ilustração abaixo, à direita, em movimento anti-horário, que também é o da suástica budista.

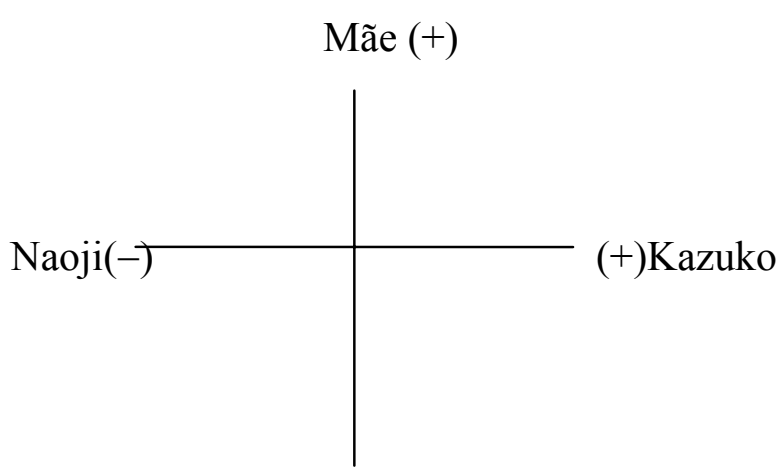

Uehara (-)

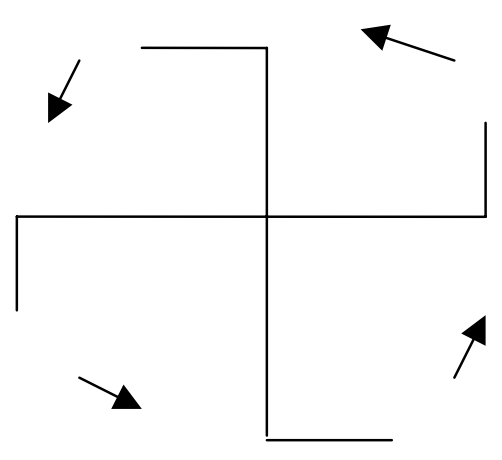

Manji 
A cruz com as quatro personagens principais nas extremidades, em mútua interação neste mundo - que, segundo o conceito budista, é de sofrimento, em que se deve amar ao próximo como a si mesmo, seguindo os preceitos confucionistas de ser uma pessoa dotada de amor fraternal e não deixar de retribuir o bem que lhe foi feito -, transforma-se em manji ou tomoe simbolizada pelo ideograma ${ }^{7}$ ou a figura ${ }^{8}$ que possibilita dois movimentos ${ }^{9}$ opostos, negativo ou positivo.

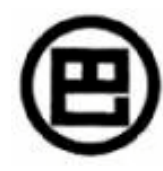

Ideograma

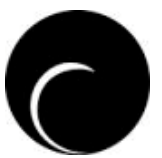

Esquerdo

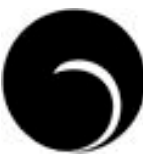

Direito

Em movimento centrípeto, a personagem volta para si mesma, encarando a vida como sofrimento, e o romance fica preso num redemoinho que não encontra saída; em movimento centrífugo, gera uma força de expansão que simboliza o amor infinito que se liga à renovação da vida, ampliando os horizontes da personagem e do romance.

Apesar do título, Pôr-do-sol não é o fim, é a esperança de um novo dia, de um novo tempo, porque a vida é cíclica. O chamado estado de Izunome ${ }^{10}$, "equilíbrio", formado pelo cruzamento do positivo e do negativo, e, por extensão, do Oriente e do Ocidente, do horizontal e do vertical, - shōjo e daijo - simbolizado pela união de duas classes, é a concretização do que Naoji almejou, e ele renascerá como filho de Kazuko com Uehara no novo mundo que está surgindo.

As obras do Romance do Eu na fase inicial acentuam a prática de associação da vida pessoal do escritor com o material narrado, fato este extraliterário, sem dúvida, que contribuiu para a aceitação do gênero. De um lado, a vida pessoal do escritor confere credibilidade à narrativa pela simples referência ao escritor como ser

\footnotetext{
7 O ideograma tomoe está no centro da circunferência.

${ }^{8}$ Há vários tipos de figuras. V. Anexo 3.

${ }^{9}$ Mokiti OKADA, Obediência ao Caminho Perfeito, p. 455.

${ }^{10}$ Mokiti OKADA, Espírito de Izunome, p. 193.
} 
humano; de outro, torna aceitável ao público uma forma que não é japonesa e que estava sendo introduzida.

Décadas depois, subvertendo os modelos originais e carnavalizando seus elementos compositivos, Dazai renova as possibilidades de sobrevivência da narrativa de cunho autobiográfico no âmbito da ficção. Ele utiliza o Romance do Eu e o romance introspectivo, além de autores como Natsume Sōseki e Mori Ōgai, contemporâneos ao surgimento dessas formas e que privilegiaram a ficção, pretendendo com isso garantir o lugar do Romance do Eu na prosa moderna japonesa, para além do rótulo que inicialmente o identificava. 


\section{BIBLIOGRAFIA}

ABE, T. et al. Nihon Kodaishi Kenkyū Jiten (Dicionário de Pesquisa da História Antiga do Japão). Tóquio, Tōkiodō Shuppan, 1995.

ADORNO, Theodor.W. Posição do Narrador no Romance Contemporâneo, in: Notas de Literatura I. Tradução de Jorge M.B. de Almeida. São Paulo, Duas Cidades; Ed. 34, 2003, p. 55-63.

AEBA, Takao. "Watakushi” o Koeru Mono (O que vai além do "eu”). Revista Kokubungaku Kaishaku to Kanshō, v. 36, n.10 Kindai Bungaku ni okeru "Watakushi", p. 43-50, setembro de 1971. "Watakushi" Shōsetsu to wa Nanika.(O que é o Romance do Eu). Revista Bungakukai, ed.especial de primavera, 1982.

Dazai Osamu no Hito to Sakuhin. (Osamu Dazai, vida e obra), in: Kanshō Nihon Kindai Bungaku 21 Dazai Osamu. Tóquio, Kadokawa, 1981.

AGUIAR, F; MEIHY, J. C. S. B. e VASCONCELOS, S. G. T. (org.) Gêneros de Fronteira. Cruzamento entre o Histórico e Literário. São Paulo, Xamã, 1997.

AKASE, S. Honkadori, Honsetsu, Honmon. Koten Bungaku no Kiiwaado.(Palavras chaves da Literatura Clássica - Honkadori, Honsetsu e Honmon). Revista Kokubungaku Kaishaku to Kyōzai no Kenkyū, p.20-21, setembro de 1985.

AKIYAMA, Ken. "Ōchō Joryū Bungaku ni okeru Sanbun Seishin to Kyokō ni tsuite. - Kagerō Nikki kara Genji Monogatari e". ("O Espírito da Prosa na Literatura Feminina da Corte Imperial — do Diário de Kagerō às Narrativas de Genji”), in: Nihon Bungaku Kenkyū Shiryō Sōsho 13 (Coleção Documentos de Pesquisa de Literatura Japonesa 13) Heianchō Nikki I. (Diário literário da corte Heian I). Tóquio, Yūseidō, 1974. P. 285-293.

Nikki to Nikki Bungaku (Diário e Literatura de Diário). Revista Kokubungaku Kaishaku to Kanshō, No 792, maio de 1997.

AKUTAGAWA, R. "Watakushi" Shōsetsu Ron Shōken. (Visão sobre a Teoria do romance do "Eu"), in: Nihon Gendai Bungaku Zenshū 56 Akutagawa Ryūnosuke Shū. ed. rev. Tóquio, Kōdansha, 1980, p. 446-448.

AMAGASAKI, Akira. Nihon no Retorikku (Estilística Japonesa), Tóquio, Chikuma Shobō, 1994.

AONO, Shūkichi. Kaisetsu (Explicação). in: Gendai Nihon Bungaku Zenshū 10 Tokuda Shūsei Shū. Tóquio, Chikuma Shobō, 1955, p. 419-425.

AONO, Yasujirō. et al. Shinpan Shakaika Söjiten (Dicionário Geral Shinpan de Sociologia), Tóquio, Meibunsha, 1974, p.1187

ARA, Masahito. Watakushi Shōsetsu Ron (Teoria do Romance do Eu). Revista Bungakukai, setembro de 1952.

ARIYOSHI, Tamotsu (org.). Waka Bungaku Jiten (Dicionário de Literatura Waka), 1982.

ASAI, K \& HAYAMI, H. Nihon Bungakushi no Matome (Resumo da História da Literatura Japonesa). Tóquio, Meiji Shoin, 1980.

ASAMI, Fukashi. Watakushi Shōsetsu Kaishaku no Hensen.(A Mudança na 
Interpretação do Romance do Eu), Revista Kokubungaku, Kaishaku to Kyōzai no Kenkyū, v. 11 n.3, p.10-15, março de 1966.

AUERBACH, Erick. Mimesis. 4. ed. São Paulo, Perspectiva, 2002. 507 p.

BACHNIK, J M. Introduction, Uchi/soto, Challenging Our conceptualizations of Self, Social Order, and Language. Situated Meaning. Inside and Outside in Japanese Self, Society, and Language. In: Self, Social Order and Language. Princeton, Princeton University Press, 1994.

BAKTHIN, Mikhail V. Problemas da Poética de Dostoievski. Tradução de Paulo Bezerra. 2. ed. revista. Rio de Janeiro, Forense Universitária, 1997. - Questões de Literatura e de Estética, a Teoria do Romance.

Tradução de Aurora Fornoni Bernadini et al. 4. ed. São Paulo, UNESP/Hucitec, 1988. . Estética da Criação Verbal. Tradução de Pauzo Bezerra. 4. ed. São Paulo, Martins Fontes, 2003.

BARTHES, Roland. Introdução à Análise Estrutural da Narrativa, in: Análise Estrutural da Narrativa. São Paulo, Vozes, 1973.

BENJAMIN: Walter. O Narrador, Considerações sobre a Obra de Nikolai Leskov, in: Magia e Técnica, Arte e Política, Ensaios sobre Literatura e História da Cultura. Tradução de Sérgio Paulo Rouanet. 7. ed. São Paulo, Brasiliense, 1994.

BRAIT, Beth. A personagem. São Paulo, Ática, 1990, Série Princípios.

BOSI, Alfredo. "As Fronteiras da Literatura”, in: Gêneros de Fronteira Cruzamento entre o Histórico e o Literário, São Paulo, Xamã/Centro Angel Rama 1977, p.11-19.

CÂNDIDO, Antonio. Ficção e Confissão. Rio de Janeiro, José Olympio, 1956. Assis, 1964. Análise Crítica do Romance. Palestra proferida na UNESP-

$$
\text { Literatura e Sociedade - Estudos de Teoria e História }
$$

Literária,

8. ed. São Paulo, T. A. Queiroz, 2000. 193 p.

CÂNDIDO, Antonio et al. A Personagem de Ficção. São Paulo, Perspectiva, 1995. $119 \mathrm{p}$.

CARVALHO, Antonio L. C. de. Foco Narrativo e Fluxo de Consciência: Questões de Teoria Literária. São Paulo, Pioneira, 1981.

CHIKAMATSU, Shūkō. Kurokami. (Cabelos Negros), in: Gendai Nihon Bungaku Taikei 21 Iwano Hōmei, Kamitsukasa Shōken, Mayama Seika, Chikamatsu Shūkō. Tóquio, Chikuma Shobō, 1970, p. 359-373 Giwaku (Suspeita), in: Nihon Gendai Bungaku Zenshū. 45 Chikamatsu Shūkō; Kasai Zenzō. Ed. Ampliada e revisada, Tóquio, Kōdansha, 1980, p. 41-75.

Wakareta Tsuma ni Okuru Tegami. (Carta Enviada a minha Ex-esposa), in: Nihon Gendai Bungaku Zenshū 45 Chikamatsu Shūkō, Kasai Zenzō Shū, ed. revista e ampliada, Tóquio: Kōdansha, 1980, p. 7-41.

CHIKANO, Shigeru. Nihon Kamon Sōkan (Registro Geral dos Emblemas de Família), 2. ed. Tóquio, Kadokawa Shoten, 1994, p. 708-709; 1058-1059.

DAZAI, Osamu. Fugaku Hyakkei (As Cem Paisagens do Monte Fuji). In: Gendai 
Nihon Bungaku Kan 36 Dazai Osamu. Bungei Shunjū, 1967. P. 371-385. Nihon Bungaku Zenshū 70 Dazai Osamu Shū, 7. ed. Tóquio,

Shūeisha, 1975, $435 \mathrm{p}$.

$108 \mathrm{p}$.

Pôr-do-Sol. Tradução de Antonio Nojiri. s/local de publicação, s/d.

Ningen Shikkaku; Guddo Bai; ta ippen (Ser Humano

Desqualificado; Adeus e mais um conto), 18. ed. Tóquio, Iwanami Shoten, 1995, 217 p.

Shayō; ta Ippen (Pôr-do-Sol e mais um conto), 12. ed. Tóquio,

Iwanami Shoten, 1995. $206 \mathrm{p}$.

DIMAS, Antonio. Espaço e Romance. 3. ed. São Paulo, Ática, 1994.

DOI, Takeo. Amae no Kōzō (Anatomia da Dependência). Tóquio, Kōbundō, 1971. Amae Zakkō (Textos Diversos sobre a Dependência). Tóquio, Kōbundō, 1975.

DOWER, John, W. The Elements of Japan Design. New York; Tóquio, Weatherhill, 1971, p. 145-146.

EAGLETON, Terry. Teoria da Literatura: Uma Introdução. Tradução de Waltensir Dutra, 5. ed. São Paulo, Martins Fontes, 2003.

ENDŌ. Shūsaku. Otoko to Kyūkanchō (O Homem e o Pintassilgo). Shinchō Nihon Bungaku 56. Tóquio, Shinchōsha, 1969, p.487-503

ENDŌ Yoshimoto. Izumi Shikibu no Shōgai. (A vida de Izumi Shikibu), in: Nihon Koten Bungaku Taikei 20 Tosa Nikki, Kagerō Nikki, Izumi Shikibu Nikki, Sarashina Nikki, 7. ed. Tóquio, Iwanami, 1964, p.384-394.

ENOMOTO, Takashi. Kindai Sakka ni Miru "Watakushi”, Tayama Katai to Tokuda Shūsei. ( O "Eu" nos Escritores Modernos, Tayama Katai e Tokuda Shūsei). Revista Kokubungaku Kaishaku to Kanshō, v. 36, n.10, Kindai Bungaku ni okeru "Watakushi", p.63-68, setembro de 1971.

Watakushi Shōsetsu no Isō (História da Literatura Shōwa:

Posição do Romance do Eu ). In: Nihon Bungaku Kenkyū Shiryō Sōsho Shōwa Bungakushi. Tóquio, Yūseidō, 1981, p. 47-63.

FIGUEIREDO, Rubens. Um Pássaro na Mão - Posfácio, in: TCHÉKHOV, Anton, $A$ Gaivota, Tradução de Rubens Figueiredo, São Paulo, Cosac\&Naify, 2004, p. 99-111.

FORSTER, Edward.M. Aspectos do Romance. Tradução de Maria Helena Martins. 2.ed. Porto Alegre, Globo, 1974, 135 p.

FRYE, Northrop. Anatomia da Crítica. São Paulo, Cultrix, 1973.

FUJIOKA, Tadami; NAKANO, Koichi \& INUKAI, Kiyoshi. Izumi Shikibu Nikki, Murasaki Shikibu Nikki, Sarashina Nikki, Sanuki no Suke Nikki.(Diário de Izumi Shikibu, Diário de Murasaki Shikibu, Diário de Sarashina, Diário de Sanuki no Suke), in: Nihon Koten Bungaku Zenshū 18 (Coleção Literatura Clássica Japonesa). Tóquio, Shōgakukan, 1971.

FURUBAYASHI, N. Kindai Sakka ni Miru "Watakushi”, Ōka Shōhei to Mishima Yukio (O "Eu" nos Escritores Modernos, Ōka Shōhei e Mishima Yukio). Revista Kokubungaku Kaishaku to Kanshō, v. 36, n.10 Kindai Bungaku ni okeru "Watakushi", p.106-113, setembro de 1971.

FURUI, Yoshikichi, "Kaisetsu" Shotai no Yukue ("Explicação", o Destino da 
Família), in: TOKUDA, Shūsei. Arashotai, Kabi, Bunguei Sensho. Tóquio, Fukunaga Shoten, 1983, p. 255-263.

GANCHO, Cândida Vilares. Como Analisar Narrativas. 4. ed. São Paulo, Ática, 1997, $70 \mathrm{p}$.

GOTŌ, Akio. "Konketsu to Bunretsu - Nihon Kindai Bungaku ni okeru Watashi" (Mestiçagem e Divisão - o Eu na Literatura Japonesa Moderna), in:

NAKANISHI, Susumu (org). Nihon Bungaku ni okeru "Watashi" ( $O$ "Eu”" na Literatura Japonesa), Tóquio, Kokusai Nihon Bunka Centaa, 1993, p.127146.

HAGITANI, Boku. Tosa Nikki Zenchūshaku (Notas explicativas completas do Diário de Tosa), 17. ed. Tóquio, Kadokawa, 1992.

HASEGAWA, Izumi. Kindai Nihon Bungaku Shichōshi (História das Tendências na Literatura Japonesa Moderna. Tóquio, Shibundō, 1966.

HASEGAWA, Izumi. Watakushi Shōsetsu to Jiden Bungaku (O Romance do Eu e a Literatura Autobiográfica). Revista Kokubungaku Kaishaku to Kyōzai no Kenkyū, v. 11, n. 3, p.59-64, março de 1966.

HASEGAWA, Izumi. Kindai Sakka ni Miru "Watakushi”, Kawabata Yasunari to Yokomitsu Riichi (O "Eu" nos Escritores Modernos Kawabata Yasunari e Yokomitsu Riichi). Revista KokuBungaku Kaishaku to Kanshō V. 36, n.10, Kindai Bungaku ni okeru "Watakushi", p.85-90, setembro de 1971.

HASEGAWA, Izumi \& TAKAHASHI, Shintarō (org. ) Bungei Yōgo no Kiso Chishiki (Conhecimentos Básicos de Termos literários), 1993.

HASEGAWA, Masaharu. Nihongaku toshite no Retorikku, Chūko Nihongo "Waka to Tsukurimono no Retorikku" Oto no Kankiryoku - kakekotoba no baai. Nihongo no Retorikku, Chōhatsusuru Gengo. (Retórica como Japonologia, Japonês Clássico. "A Retórica do Poema Waka e das Criações", O Poder de Sedução do Som - o Caso do Kakekotoba. Retórica do Japonês, Idioma Expansivo), Revista Kokubungaku Kaishaku to Kyōzai no Kenkyū, p. 77-81 janeiro de 1999.

HAUSER, Arnold. História Social da Arte e da Literatura. Tradução de Álvaro Cabral, São Paulo, Martins Fontes, 1994, 1032 p.

HIDAKA, Shōji. "Kindai Shōsetsu" Riron no Shosō (Aspectos Teóricos do "Romance Moderno"), in: Kōza Shōwa Bungaku Shi 3 Yokuatsu to KaihōSenchū kara Sengo e. Tóquio, Yūseidō, p. 164-173.

HINOTANI, Hirohiko, 1994, p. 6

HIJIYA-KIRSCHNEREIT, Irmela H. Watakushi Shōsetsu, Jikobakuro no Gishiki. (Romance do Eu, um Ritual de Auto-revelação), Tradução para o japonês de Mishima Ken'ichi et. al. Tóquio, Heibonsha, 1992. 584 p.

HIRANO, Ken. Watakushi Shōsetsu Ron (Teoria do Romance do Eu), in: HISAMATSU, Sen'ichi \&YOSHIDA, Seiichi. Kindai Nihon Bungaku Jiten. Tóquio, Tōkyōdō Shuppan, 1959. Shinchō Nihon Bungaku Shō Jiten (Pequeno Dicionário Shinchō de Literatura Japonesa) Hirano Ken Sakkaron Shū (Coletânea de Teses sobre Autores por Hirano Ken) Tóquio, Shinchōsha, 1971. Watakushi Shōsetsu no Niritsu Haihan.(A Antinomia do Romance do 
Eu), in: Kanshō Nihongendai bungaku, Tóquio, Kadokawa Shoten, 1985, p. 224-247.

HIRAOKA, Toshio. Watakushi Shōsetsu no Kyokōsei (A Ficcionalidade do

Romance do Eu). Revista Kokubungaku Kaishaku to Kyōzai no Kenkyū. V. 11, n. 3. p.81-87, março de 1966.

Kindai Sakka ni Miru "Watakushi”, Kitamura Tōgoku to

Shimazaki Tōson (O "eu" nos Autores Modernos, Kitamura Tōgoku e Shimazaki Tōson). Revista Kokubungaku Kaishaku to Kanshō V. 36, n.10 Kindai Bungaku ni okeru "Watakushi", p. 52-58, setembro de 1971.

HIRAOKA, Toshio \& TŌGŌ, Katsumi. Nihon Bungaku Shi Gaisetsu (História da Literatura Japonesa, Considerações Gerais), v. Era Moderna. Tóquio, Yūseidō, 1979, Taishō Zenki. Nishigaki Tsutomu (org.)

HIROTSU, Kazuo. Tokuda Shūsei Ron. (Tese sobre Tokuda Shūsei), in: Gendai Nihon bungaku zenshū 10 Tokuda Shūsei Shū, Tóquio, Chikuma Shobō, 1955, p. 398-418.

HISAMATSU, Sen'ichi. Nihon Bungaku Shi (História da Literatura Japonesa), Tóquio, Shibundō.

HISAMATSU, Sen'ichi \& YOSHIDA, Seiichi (org.) Kindai Nihon Bungaku Jjiten (Dicionário de Literatura Moderna) ed. Revista e ampliada, Tóquio, Tosho Insatsu Kabushikigaisha, 1979.

HISAMATSU, Sen'ichi et al. Gendai Nihon Bungaku Daijiten (Grande Dicionário de Literatura Japonesa Contemporânea), ed. revista e ampliada, Tóquio, Meiji Shoin, 1968.

HOSHŌ, M. Senjika ni Okeru Watakushi Shōsetsu Sakka - Kawasaki Chōtarō no Baai (Os Escritores do Romance do Eu durante a Guerra - no Caso de Kawasaki Chōtarō. Revista Kokubungaku Kaishaku to Kyōzai no Kenkyū. V. 11, n.3, p.46-52, março de 1966.

IBUSE, Masuji. Koi; Sanshōuo; Yōhai Taichō; ta nana hen. (A Carpa; A Salamandra; Comandante Devoto à Distância e outros sete contos), 43.ed. Tóquio, Iwanami Shoten, 1994.

ICHIKO, Teiji. Nihon Bungaku Zenshi. (História Geral da Literatura Japonesa), Tóquio, Gakutōsha, 1978.

(org.). Nihon Bungaku Zenshi 2 Chūko (História Geral da Literatura Japonesa 2 Média Antigüidade), 2. ed ampliada e revisada, Tóquio, Gakutōsha, 1993.

IKEDA, Kikan. "Nikki Bungaku to Kikō Bungaku” (Diário Literário e Relato de Viagem Literário), in: Nihon Bungaku Kenkyū Shiryō Sōsho Heianchô Nikki I Tóquio, Yūseidō, 1974. . (org.) Joryû Nikki Bungaku to wa nani ka. (O que é o Diário Literário Feminino), in: Joryū Nikki Bungaku Kōza, v. 2, Tóquio, Benseisha, 1991.

. Heian Jidai no Bungaku to Seikatsu. (A Literatura e a Vida da Era Heian) Tóquio, Shibundō, 1973.

IKUTA, Chōkō. Nichijō Seikatsu o Henchō Suru Akukeikō (Uma tendência que superestima o cotidiano), Revista Shinchō, julho de 1924.

IMAI, Takuji. Kodai no Nikki, Kikō Bungaku. (Diário Literário; Relato de Viagem 
do Período Antigo), in: Iwanami Kōza Nihon Bungaku Shi, v. 3 Kodai, Tóquio, Iwanami Shoten, 1959.

(org.) Joryū Nikki Bungaku Kōza (Curso de Literatura de Diário

Feminino) v. 1, 2, 3, 4, 5 e 6, Tóquio, Benseisha, 1991.

IMAZEKI, Toshiko. Chūsei Joryū Nikki Bungaku Ronkō (Estudos sobre a Literatura de Diários Femininos do Período Médio), Osaka, Izumi Shoin, 1987.

INAGAKI, T. Watakushi Shōsetsu o Megutte (Em torno ao Romance do Eu), Kokubungaku, Kaishaku to Kyōzai no Kenkyū, v.11, n.3, p. 8-10, março de 1966.

INO, Kenji. Nihon Kindai Bungaku Daijiten (Grande Enciclopédia da Literatura Japonesa Moderna)

INOUE, Kiyoshi. Nihon no Rekishi (Chü). (História da Literatura Japonesa) v. 2, Tóquio, Iwanami Shoten, 1965

INSTITUTO ANTONIO HOUAISS. Dicionário Houaiss da Língua Portuguesa, Versão 1.05.5a. Rio de Janeiro, Editora Objetiva, 2002.

INUMARU, Giichi \& NAKAMURA, Shin'ichirō. Monogatari Nihon Kindai Shi

2, (História da Narrativa Moderna 2), Tóquio, Shin Nippon Shuppansha, 1970.

ISHIDA, Yoshisada. Chūsei no Nikki, Kikō Bungaku. (Diário Literário, Relato de Viagem do Período Médio), in: Iwanami Kōza Nihon Bungaku Shi (Curso Iwanami da História da Literatura Japonesa), v. 4, Chūsei, Tóquio, Iwanami Shoten, 1958.

ISHIDA, Ichirō (org.) Kindai Bungei no Keisei, (Formação da Arte Literária Moderna), in: Nihon Bunkashi Gairon. Tóquio: Yoshikawa Hirofumikan, 1968, p.503-518 Nihon Bunkashi - Nihon no Kokoro to Katachi (História da Cultura Japonesa - o Sentimento e Forma do Japão), Tóquio, Tōkai Daigaku Shuppan Kai, 1989, p. 171-172.

ISHIRAHA, S. (org.) Nikki Bungaku Jiten (Dicionário de Literatura de Diários). Tóquio, Benseisha, 2000.

ISOGAI, Hideo. Watakushi Shōsetsu no Seiritsu to Henshitsu. (Formação e Transformação do "Romance do Eu") Kokubungaku Kaishaku to Kyōzai no Kenkyū, julho de 1967.

Kindai Sakka ni Miru "Watakushi”, Kamura Isota to Kajii Motojirō (O "Eu" nos Escritores Modernos, Kamura Isota e Kajii Motojirō). Revista Kokubungaku Kaishaku to Kanshō, v. 36, n.10, Kindai Bungaku ni okeru "Watakushi", p.90-95, setembro de 1971.

Dazai Osamu Ron , (Tese sobre Osamu Dazai), in: Nihon Bungaku Kenkyū Shiryō Sōsho Dazai Osamu. Tóquio, Yūseidō, 1972, p. 11-18.

ISOTA, Kōichi(org.) et al. Shinchō Nihon Bungaku Jiten (Dicionário Shinchō de Literatura Japonesa), Tóquio, Shinchōsha, 1988.

ITŌ, Sei. Shōsetsu no Hōhō (Método do Romance), Tóquio, Kawade Shobō, 1951. Bungaku Nyūmon (Introdução à Literatura).Tóquio, Kōbunsha, 1986.

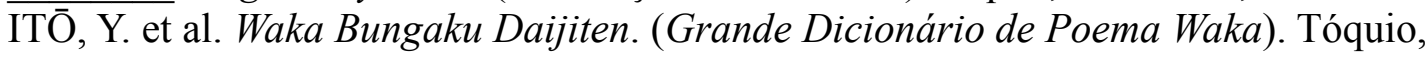
Meiji Shoin, 1962.

JAMES, Henry. A Arte da Ficção. Tradução de Daniel Piza. São Paulo, Imaginário, 
1995. $127 \mathrm{p}$.

KABUSHIKIGAISHA HAMASHIMA SHOTEN, Saishin Kokugo Binran, Nagoya, Hamashima Shoten, 1993. 297 p.

KAJII, Motojirō Remon (Limão), in: Nihon Bungaku Zenshū 34. Kajii Motojirō, Kamura Isota, Nakajima Atsushi. Tóquio, Shinchōsha, 1962, 9-14.

KAMEI, Hideo. "Modoki" no Hōhō - Sakka no Shutsugen to Jimetsu (Método do modoki - Surgimento e Destruição do Escritor) in: Nihon Bungaku Kenkyū Shiryō Sōsho Dazai Osamu II. Tóquio, Yūseidō, 1985, p. 79-84.

KAMURA, Isota. Gake no Shita (Sob o Precipício), in: Nihon Bungaku Zenshū 34 Kajii Motojirō, Kamura Isota, Nakajima Atsushi. Tóquio, Shinchōsha, 1962, p. 159-179.

KANBAYASHI, Akatsuki. Sei Yohane Byōin ni te (No Hospital São João), in: Gendai Nihon Bungaku Zenshū 40. Takii Kōsaku, Ozaki Kazuo, Tonomura Shigeru, Kanbayashi Akatsuki shū. Tóquio, Chikuma Shobō, 1955, p. 360374.

KANŌ, Masanao. Nihon no Rekishi n. 27 Taishō Demokurashii (História do Japão

$n$. 27Democracia Taishō), Tóquio, Shōgakukan, 1967.

KARATANI, Kōjin. Kokuhaku to Sono Seido (A Confissão e o seu Sistema) e Hanashi no nai Shōsetsu Ronsō. (Discussões sobre os Romances sem "Enredo"), in Nihon Kindai Bungaku no Kigen. (Origens da Literatura Japonesa Moderna), Tóquio, Kōdansha, 1988.

KASAHARA, Nobuo. Kindai Sakka ni Miru "Watakushi" Yasuoka Shōtarō to Shimao Toshio ( O "Eu" nos Escritores Modernos Yasuoka Shōtarō e Shimao Toshio), Revista Kokubungaku Kaishaku to Kanshō, v. 36, n.10 Kindai Bungaku ni okeru "Watakushi”, p.114-119, setembro de 1971.

KASAI, Zenzō. Aishiki Chichi (Pai Digno de Compaixão, 1912), in: Nihon Bungaku Zenshū 31; Kasai Zenzō, Kamura Isota shū. Tóquio, Shūeisha, 1969, p. 9-16.

KATSUYAMA, Isao. Taishōki ni okeru Watakushi Shōsetsu no Keifu (Linhagem Taishō do Romance do Eu), Revista Kokubungaku, Kaishaku to Kyōzai no Kenkyū, v. 11, n.3, p.32-37, março de 1966.

Taishō Watakushi Shōsetsu Kenkyū. (Pesquisa Comparativa do Romance do Eu), Tóquio, Meiji shoin, 1983.

KAWAKAMI, Tetsutarō. Kaisetsu Kajii Motojirō. (Explicação), in: Nihon Bungaku Zenshū 34. Kajii Motojirō, Kamura Isota, Nakajima Atsushi. Tóquio, Shinchōsha, 1962, p. 441-449.

KAWABATA, Yasunari. Kaisetsu (Explicação), in: Nihon no Bungaku 9 Tokuda Shūsei (I) Tóquio, Chūō Kōronsha, 1967, p.511-526.

KAWAHIRA, H. [Uta] to Seido, Kagaku to Kadō. ("Poema" e Sistema, Ciência Poética e Caminho da Poesia), Revista Kokubungaku Kaishaku to Kyōzai no Kenkyū, p. 66-73, novembro de 1989.

KAWASAKI, T. Bunseki Hihyō Nyūmon (Introdução à Análise Crítica), Tóquio, Shibundō, 1970.

KAYSER, Wolfgang. Análise e Intepretação da Obra Literária. Coimbra, Armênio Amado Editor, 1958.

KEENE, Donald. Nihon no Bungaku. (A Literatura Japonesa) Tradução para o 
Japonês de Yoshida Ken'ichi, Tóquio, Chūō Kōronsha, 1979.

KEENE, Donald. Nihon Bungaku no Rekishi 14 Kindai/Gendai-hen 5 (História da

Literatura Japonesa 14 Volume moderno e contemporâneo 5). Tradução para o Japonês de Tsunoji Yukio, Tóquio, Chūō Kōronsha, 1996.

KIMURA, M. et al. Nihon Bungaku Kōza - Nikki, Zuihitsu, Kiroku 7 (Curso de Literatura Japonesa - Diário, Ensaios, Registros 7), Tóquio, Nihon Bungaku Kyōkai, 1989.

KIMURA, Y. Watakushi Shōsetsu to Shakaisei (O Romance do Eu e o Caráter Social), Revista Kokubungaku Kaishaku to Kyōzai no Kenkyū. V. 11, n. 3, p.87-92, março de 1966.

KINDAICHI, Haruhiko; HAYASHI, Oki \& SHIBATA, Takeshi. Nihongo Hyakka Daijiten (Grande Enciclopédia de Língua Japonesa), Tóquio, Taishūkan, 1988.

KINO Tsurayuki. Tosa Nikki (Diário de Tosa), in: Shin Nihon Koten Bungaku Taikei 24, Tóquio, Iwanami, 1994.

KITAZUMI Toshio \& KIKUDA Shigeo. "Kindai bungei no keisei” (“Capítulo 30 Formação da arte literária moderna"), in ISHIDA, Ichirō. Nihon Bunkashi Gairon. (Introdução à História Cultural do Japão).

KOBAYASHI, Hideo. "Watakushi Shōsetsu Ron" (Teoria do Romance do Eu), in Kobayashi Hideo Zenshū III, Tóquio, Shinchōsha, 1968, p.119-145.

KOKUBO, Minoru. Dazai Osamu - Sono Bungaku no Hōhō (Osamu Dazai, seu Método Literário), in: Nihon Bungaku Kenkyū Shiryō Sōsho Dazai Osamu. Tóquio, Yūseidō, 1972, p. 90-103.

KOMASHAKU, Kimi. Kyojitsu Himaku no Seishin - Dazai Osamu Ron (Espírito de Camuflagem da Verdade e da Mentira - Teoria sobre Osamu Dazai), in: Nihon Bungaku Kenkyū Shiryō Sōsho Dazai Osamu, Tóquio, Yūseidō, 1972, p. $42-54$.

KŌNO, Toshirō. Watakushi shōsetsu ni okeru Shirakabaha no yakuwari (A função da Corrente Shirakaba no romance do eu). Revista Kokubungaku Kaishaku to Kyōzai no Kenkyū. V. 11, n. 3. p.26-31, março de 1966.

Kindai Sakka ni Miru "Watakushi”, Mushanokōji Saneatsu to Arishima Takeo - Kankōkaibon o Megutte ( O "Eu" nos Escritores Modernos, Mushanokoji Saneatsu e Arishima Takeo - sobre o livro da associação de publicação), Revista Kokubungaku Kaishaku to Kanshō, v. 36, n.10, Kindai Bungaku ni okeru "Watakushi”, p.74-79, setembro de 1971.

KUBOTA, Jun. \& UENO, O. Compêndio da História da Literatura Japonesa. (Gaisetsu Nihon Bungakushi). Tóquio, Yūhikaku, 1979.

KUBOTA, Mantarō. Watakushi Shōsetsu to Tankateki Jojō - Tasho no Gobō (O Romance do Eu e o Lirismo dos Poemas Tanka - a Bardana de outro lugar). Revista Kokubungaku Kaishaku to Kyōzai no Kenkyū, v. 11, n. 3, p.71-74, março de 1966.

KUME, Masao. Watakushi Shōsetsu to Shinkyō Shōsetsu (Romance do Eu e Romance Introspectivo), in: Nihon Gendai Bungaku Zensh 57 Kikuchi Hiroshi/Kume Masao shū, ed. revisada, Tóquio, Kōdansha, 1980, p. 406411. 
Literatura Pura) in: Nihon Gendai Bungaku Zensh 57 Kikuchi Hiroshi/Kume Masao Shū, ed. revisada, Tóquio, Kōdansha, 1980, p. 411-413.

KURAHARA, Korehito. Watakushi Shōsetsu Shikan (Minha Visão sobre o Romance do Eu). Revista Bungaku, v.21, n.12, p. 73-76, dezembro de 1953.

LUKÁCS, George. Teoria do Romance. Tradução de Alfredo Margarido, Lisboa, Presença 1962.

.Narrar ou Descrever, in: Ensaios sobre a Literatura. São Paulo, Civilização Brasileira, 1965.

LEITE, Ligia. C M. O Foco Narrativo. São Paulo, Ática, 1985. Série Princípios, 96p.

LEJEUNE, Philippe. Le Pacte Autobiographique. Paris, Seuil, 1975.

MAEDA, Noboru. Kaidai (Esclarecimento), in: KATAI, Tayama. Futon; Ippeisotsu. Tóquio: Iwanami Shoten, p.107-110.

MAEDA, Ai \& HASEGAWA, Izumi. Nihon Bungaku Shinshi-Kindai (Nova História da Literatura Japonesa - Era Moderna), Tóquio, Shibundō, 1991.

MAINGUENEAU, Dominique. O Contexto da Obra Literária-Enunciação, escritor, sociedade. Tradução de Marina Appenzeler; revisão da tradução de Eduardo Brandão, São Paulo, Martins Fontes, 1995. 202 p.

MAKINO, Shin'ichi. Chichi o Uru Ko (Filho que Vende o Pai), in: Nihon Gendai Bungaku Zenshū 74. Makino Shin'ichi, Kamura Isota, Hōjō Tamio Shū. Edição revista e ampliada. Tóquio, Kōdansha, 1980, p. 11- 19.

Kinada Mura (Vila Kinada), in: Nihon Gendai Bungaku Zenshū 74. Makino Shin 'ichi, Kamura Isota, Hōjō Tamio Shū. Edição revista e ampliada. Tóquio, Kōdansha, 1980, p. 153-162.

MASAMUNE, Hakuchō. Sensaisha no Kanashimi (A Tristeza das Vitimas de Guerra), in: Nihon Bungaku Zenshū 11 Masamune Hakuchō Shū, 4. ed. Tóquio, Shūeisha, 1972. p. 297-306.

MATSUBARA, S. Hōhō to shite no "Watakushi" (O "Eu" como Método), Revista Kokubungaku Kaishaku to Kanshō, v. 36, n.10, Kindai Bungaku ni okeru "Watakushi", p. 30-36, setembro de 1971.

MATSUMURA, S. (org.) Tsutsumi Chūnagon Monogatari; Ochikubo Monogatari (Narrativa Tsutsumi Chūnagon; Narrativa Ochikubo), in Nihon Koten Zensho,

Tóquio; Osaka; Ogura; Nagoya, Asahi Shinbunsha, 1951.

MATSUOKA, Seigō. Omokage no Kuni, Utsuroi no Kuni - Nihon no Henshū Bunka o Kangaeru (País dos Vestígios, País das Transposiçõess - Reflexões sobre a Cultura da Edição), in: NHK Ningen Kōza, Tóquio, NHK Shuppan Kyōkai, 2004. 191p.

MAY, Georges. L'autobiographie. Paris, PUF, 1979.

MELETÍNSKI, Eleazar. M. Os Arquétipos Literários. $2^{\mathrm{a}}$ edição. Tradução de Aurora Fornoni Bernardini, Homero Freitas de Andrade e Arlete Cavaliere. São Paulo, Ateliê Editorial, 2002. 315p.

MIYATA, Kazuichirō (org.). Nihon Koten Zensho Utsuho Monogatari I, II, III (Narrativa Utsuho I, II, III), 5. ed. Tóquio; Osaka; Ogura; Nagoya, Asahi Shinbunsa, 1956.

MIYOSHI, Y. Shōwa ni okeru Watakushi Shōsetsu Sakka (Os Autores do Romance 
do Eu em Shōwa), Revista Kokubungaku Kaishaku to Kyōzai no Kenkyū, v. 11, n. 3, p. 43-45, março de 1966.

Kindai Bungaku ni okeru "Watakushi" Subyō (Descrição do "Eu" na

Literatura Moderna), Revista Kokubungaku Kaishaku to Kanshō, v. 36, n. 10,

Kindai Bungaku ni okeru "Watakushi”, p. 10-14, setembro de 1971.

MORIKAWA, T. Jitsuzon to shite no "Watakushi" $(\mathrm{O}$ "Eu" enquanto Existência

Real), Revista Kokubungaku Kaishaku to Kanshō, v. 36, n. 10, Kindai Bungaku ni okeru "Watakushi", p. 37-42, setembro de 1971.

MULHERN, Chieko, I. Japanese Women writers, A Bio-critical Sourcebook. s.l., Greenwood Press. 1994.

MUSHANOKŌJI, Minoru. Suetsumuhana no Himegimi — Fujiwara Jidai no Joryū Bungaku no Kiban. (A Princesa Suetsumuhana - as Bases da Literatura Feminina na Época Fujiwara), Revista Bungaku, Tóquio, v.17 ge. p.44-53, agosto de 1949.

MUTŌ, Motoaki. "Hiraga Gen'nai" in revista Kokubungaku Kaishaku to Kanshō v. Kinsei shōsetsu no sakusha tachi. n. Especial p. 67-71, agosto de 1994.

NAGAE, Neide H. O Surgimento do Diário como Obra Literária na Literatura 2002.

Clássica Japonesa" Revista Estudos Japoneses 22, p.91-102, CEJ- USP,

Recursos Estilísticos da Poesia Japonesa - o Kakekotoba e o

Honkadori. XIV ENPULLCJ, Assis, 2003. Anais XIV ENPULLCJ, Assis, Unesp, 2003. p.339-47.

NAKAMURA, Mitsuo. Fūzoku Shōsetsu Ron - Kindai Riarizumu Hihan (Teoria do

Romance de Costumes, Crítica do Realismo Moderno), Tóquio, Kawade

Shobō, 1951.

Nihon no Kindai Shōsetsu. (Romance Moderno Japonês),

Tóquio, Iwanami Shoten. 1954

Nihon no Gendai Shōsetsu. (Romance Contemporâneo

japonês), Tóquio, Iwanami Shoten, 1954 b

Fūzoku Shōsetsu Ron - Kindai Riarizumu Hihan (Teoria do

Romance de Costumes, Crítica do Realismo Moderno), in: Nakamura Mitsuo

Zenshū, v. 7. Tóquio, Chikuma shobō, 1972. p. 526-634.

Puroretaria Bungaku Undō - sono Bungakushiteki Igi, in:

Nakamura Mitsuo Zenshū, v. 7, Tóquio, Chikuma Shobō, 1972. p.70-74.

Watakushi Shōsetsu ni tsuite, in: Nakamura Mitsuo Zenshū,

v. 7. Tóquio, Chikuma Shobō, 1972, p.116-140.

Kidai Nihon Bungaku, in: Nakamura Mitsuo Zenshū, v. 7.

Tóquio, Chikuma Shobō, 1972, p. 414-447.

Nihon no Kindaika, in: Nakamura Mitsuo Zenshū, v. 13.

Tóquio, Chikuma Shobō, 1973, p.102-134.

Nihon no Kindai, in: Nakamura Mitsuo Zenshū, v. 13.

Tóquio, Chikuma Shobō, 1973. 287-295.

Naturalismo, in: Shinchō Nihon Bungaku Jiten, 1988,

p.595-599.

NAKAMURA, Murao. Honkaku Shōsetsu to Shinkyō Shōsetsu (Romance Autêntico e Romance Introspectivo), Revista Shin Shōsetsu, janeiro de 1924. 
NAKAMURA Yukihiko. 25 Shō Bungei no hensen (Capítulo 25, Transformações das Artes Literárias), in: ISHIDA, Ichirō (org.). Nihon Bunkashi Gairon Tóquio: Yoshikawa Hirofumikan, 1968, p.415-432.

NAKANO, Yoshio. Kaisetsu (Explicação). In Kindai Nihon Bungaku Kan Shimazaki Tōson I, Tóquio, Bungei Shunjū, 1967, p. 522

NAKATA, Iwao. Shinsen Kogo Jiten (Nova seleção - Dicionário de Língua Clássica), Tóquio, Shōgakukan, 1963.

NANBA, Hiroshi (org). Nihon Koten Zensho 96 Taketori Monogatari; Ise Monogatari, ed. revisada,Tóquio; Osaka; Ogura; Nagoya, Asahi Shinbunsha, 1960.

NIHON BUNGAKU KENKYŪ SHIRYŌ KANKŌKAI. (ASSOCIAÇÃO DE PUBLICAÇÃO DE DOCUMENTOS DE PESQUISA DE LITERATURA JAPONESA Nihon Bungaku Kenkyû Shiryō Sōsho Heian chō Nikki I. (Coleção Documentos de Pesquisa de Literatura Japonesa Diário literário da corte Heian I), Tóquio, Yuseidō, 1971.

Heian chō Nikki II. (Coleção

Documentos de Pesquisa de Literatura Japonesa Diário Literário da Corte Heian II), ,1975.

NISHIGAKI, T. Kindai Sakka ni Miru "Watakushi", Shiga Naoya to Akutagawa Ryūnosuke - "Watakushi" aruiwa "Kakugo" ni tsuite no Jo. (O "Eu" nos Escritores Modernos, Shiga Naoya e Akutagawa Ryūnosuke - o Prefácio sobre o "Eu" ou o "Estar Ciente"), Revista Kokubungaku Kaishaku to Kanshō, v. 36, n.10 Kindai Bungaku ni okeru "Watakushi", p.79-85, setembro de 1971.

NISHIKI, Jin. Honkadori. (Honkadori), Revista Kokubungaku Kaishaku to Kyōzai no Kenkyu, ed. extra ampliada, Koten Bungaku Retorikku Jiten [heisai] Koten Bungaku Imeeji Jiten, p. 142-143, fevereiro de 1989.

NOMURA, H. (org.). Nihon Koten Zensho Ujishüi Monogatari. (Coleção Literatura Japonesa Clássica Narrativa Ujishūi), Tóquio; Osaka; Ogura; Nagoya, Asahi Shinbunsha, 1951.

NUNES, Benedito. O tempo na narrativa. 2. ed. São Paulo, Ática, 1995. 84 p.

ODAGIRI, Hideo. Nihon Gendaishi Taikei Bungakushi. (História da Literatura Japonesa na História Moderna do Japão) Tóquio, Tōyō Keizai; Shinpōsha, 1961.

. Watakushi Shōsetsu to Shinkyō Shōsetsu.(Romance do Eu e Romance Introspectivo) In: Iwanami kōza nihon bungaku shi 12, Tóquio, Iwanami, 1958. 38 p.

ODAGIRI, Susumu \& NIHON KINDAI BAUNGAKU KAN Nihon Kindai Bungaku Daijiten. (Grande Dicionário de Literatura Moderna Japonesa). 3. ed. Tóquio, Nihon Kindai Bungakukan, 1978.

. Nihon Kindai Bungaku Daijiten. Grande Dicionário de Literatura Moderna Japonesa. Tóquio, Kōdansha, 1984.

OGASAWARA, Katsumi. Watakushi Shōsetsu ni Okeru "Watakushi" - Mondai no Kiten, Itō Sei no Hōhō ni Karamete (O "Eu" no Romance do Eu - Origem do Problema, Segundo o Método de Itō Sei). Revista Kokubungaku Kaishaku to 
Kanshō, v. 36, n.10 Kindai Bungaku ni okeru "Watakushi”, p. 23-30, setembro de 1971.

OIKAWA, Shōsetsu. Bungei Yōgo no Kiso Chishiki 88 (Conhecimentos Básicos de Termos Literários 88), 5.ed.revista e ampliada. Revista Kokubungaku Kaishaku to Kanshō, v. Edição extra ampliada, p. 358-359, novembro de 1988.

OKA, Kazuo. Heianchō Bungaku Jiten (Dicionário Literário da Corte Heian). Tóquio, Toquiodō, 1972. Bungei Yōgo no Kiso Chishiki 88 (Noções Básicas de Termos Literários 88), 5. ed. revisada e ampliada. Revista Kokubungaku Kaishakuto Kanshō, n. extra e ampliado, outubro de 1988.

ŌKA, Shōhei. Hoshō no Me ni tsuite (A respeito dos Olhos do Vigia), in: Nihon no Bungaku 70 Ōka Shōhei. Tóquio, Chūō Kōronsha, 1965. p. 57-62

OKADA, Mokiti. Espírito de Izunome, in: Alicerce do Paraíso, 14.ed. São Paulo, Fundação Mokiti Okada, 2000, p.193. . Obediência ao Caminho Perfeito, in: . O que é limite, in: p.472 p. 455.

OKETANI, H. Kindai Jiga to Kojinshugi (O Ego Moderno e o Individualismo). Revista Kokubungaku Kaishaku to Kanshō, v. 36, n.10, Kindai Bungaku ni okeru "Watakushi”, p. 16-23, setembro de 1971.

OKIURA, Kazuteru. Dazai Osamu Ron Nooto, in: Nihon Bungaku Kenkyū Shiryō Sōsho Dazai Osamu. Tóquio, Yūseidō. 1972. P. 1-10.

OKUBO, M. Kindai Sakka ni Miru "Watakushi", Noma Hiroshi to Takeda Taijun (O "Eu" nos Escritores Modernos, Noma Hiroshi e Takeda Taijun), Revista Kokubungaku Kaishaku to Kanshō, v. 36, n. 10, Kindai Bungaku ni okeru "Watakushi”, p.101-106, setembro de 1971.

ŌKUBO, Norio. Kindai Sakka ni Miru "Watakushi”, Iwano Hōmei to Chikamatsu Shūkō Revista Kokubungaku Kaishaku to Kanshō ( O "Eu" nos Escritores Modernos, Iwano Hōmei e Chikamatsu Shūkō). V. 36, n.10, Kindai Bungaku ni okeru "Watakushi", p.68-73, setembro de 1971. Dazai Osamu Kenkyū e no Ichi Shiten - "Monogatari” no Sōshitsu to Shi, in: Nihon Bungaku Kenkyū Shiryō Sōsho, Tóquio, Yūseidō, 1985, p. $85-91$.

ŌKUBO, T. Shizen Shugi to Watakushi Shōsetsu.(O Naturalismo e o Romance do Eu),Kokubungaku Kaishaku to Kyōzai no Kenkyū, v. 11, n.3, p.20-25, março de 1966.

OKUBO, Tsuneo \& TAKAHASHI, Haruo. Gendai Bungaku Kenkyū Jiten. 1983

OKUNO, Takeo. Explicação. (Kaisetsu), in: Shinchō Nihon Bungaku 35 Dazai Osamu Shū. 20.ed. Tóquio, Shinchōsha, 1992. p. 638-650. Kono Issatsu de Nihon no Sakka ga Wakaru (Informações sobre os Escritores Japoneses em um Único Volume), Tóquio, Mikasa Shobō, 1997, $428 \mathrm{p}$.

ŌMORI, S. Watakushi Shōsetsuka Kenkyū (Pesquisa dos Romancistas do Eu) Tóquio, Meiji Shoin, 1982.

ŌTSU, Tōru. Michinaga to Kyūtei Shakai. (Michinaga e a Sociedade da Aristocracia antiga), in: Nihon no Rekishi 6 (História do Japão), Tóquio, Kōdansha 2001.

OZAKI, Kazuo. Mushi no Iroiro (Diversidade dos Insetos), in: Gendai Nihon 
Bungaku Zenshū 40. Takii Kōsaku, Ozaki Kazuo, Tonomura Shireu, Kanbayashi Akatsuki Shū. Tóquio, Chikuma Shobō, 1955, p. 143-148.

REIS, Carlos \& LOPES, Ana Cristina M. Dicionário de Teoria da Narrativa. São Paulo, Ática, 1988, 327 p.

REUTER, Yves. Introdução à Análise do Romance. Tradução de Angela Bergamini et al.São Paulo, Martins Fontes, 1996. 187 p.

SAIGŌ, Nobutsuna. Kyūtei Joryū Bungaku no Mondai I - Heian Bungaku Nooto to shite (O problema da literatura feminina palaciana I - Anotações da literatura Heian), Revista Bungaku, v. 17 ge, p. 494-507, agosto de 1949a . Kyūtei Joryū Bungaku no Mondai II - Heian bungaku nôto to shite (O problema da literatura feminina palaciana II - Anotações da literatura Heian), Revista Bungaku, v. 17 ge, p.581-592, setembro de 1949b.

SAIGŌ, Nobutsuna, NAGAZUMI, Yasuaki \& HIROSUE, Tamotsu. Nihon Bungaku no Koten (Os Clássicos da Literatura Japonesa) 2. ed. Tóquio, Iwanami shoten, 1972

SALOMON, Délcio V. Como fazer uma monografia. 3. ed. São Paulo, Martins Fontes, 1994. 294 p.

SASAKI, Y. Uta, Utakotoba, Utamakura [Uta] narumono - Koten Jidai no Kajin no Jōken. Revista Kokubungaku Kaishaku to Kyōzai no Kenkyū, p. 52-53, novembro de 1989.

SATŌKIBIUE, M. Kindai Sakka ni Miru "Watakushi”, Ishihara Shintarō to Ōe Kenzaburō ( O "Eu" nos Escritores Modernos, Ishihara Shintarō e Ōe Kenzaburō). Revista Kokubungaku Kaishaku to Kanshō, v. 36, n.10 Kindai Bungaku ni okeru "Watakushi”, p.119-124, setembro de 1971.

SARRA, Edith. Fictions of Femininty - Literary Inventions of Gender in Japanese Court Women's Memos. Stanford, Stanford University Press, 1999.

SATŌ, Haruo. Shinkyō Shōsetsu to Honkaku Shōsetsu (Romance Introspectivo e Romance Autêntico), Revista Chuō Kōron, março de 1928.

SATŌ, M. Puroretaria bungaku ni okeru watakushi shōsetsu - sono tenkō bungaku ni okeru isō oboegaki ( $\mathrm{O}$ romance do eu na literatura proletária - anotações sobre a sua situação na literatura de mudança). Revista Kokubungaku Kaishaku to Kyōzai no Kenkyū. V. 11, n. 3, p.37-42, março de 1966.

SATŌ, Takeyoshi. Kakekotoba. Revista Kokubungaku Kaishaku to Kyōzai no Kenkȳu,

ed. extra ampliada.Koten Bungaku Retorikku Jiten [heisai] Koten Bungaku Imeeji Jiten, p. 86-87, fevereiro de 1989.

SCHÜLLER, Donaldo. Teoria do Romance. São Paulo, Ática, 1989. 88 p.

SEKIGUCHI, Yasuo. Kaisetsu (Explicativa), in: Nihon Bungaku Kenkyū Shiryō Sōsho Watakushi Shōsetsu, Tóquio, Yūseidō, 1983.

SENUMA, Shigeki. Watakushi Shōsetsu to Shinkyō Shōsetsu (Romance do Eu e Romance Introspectivo) Kokubungaku, Kaishaku to Kyōzai no Kenkyū, v. 11 n.3, p.14-19, março de 1966.

SENUMA, Shigeki; YABE, S \& SUGIZAKI, T. Nihon Bungaku Shi (História da Literatura Japonesa ) Tóquio, Ōfūsha, 1976.

SEVERINO, Antonio. J. Metodologia do Trabalho Cientifico. 22. ed. revista. e ampliada de acordo com a ABNT - São Paulo, Cortez, 2002. 
SHIGEMATSU, Y. Kindai Sakka ni Miru "Watakushi", Mori Ōgai to Natsume Sōseki. Revista Kokubungaku Kaishaku to Kanshō (O "Eu" nos Escritores Modernos, Mori Ōgai e Natsume Sōseki), v. 36, n.10, Kindai Bungaku ni okeru "Watakushi", p. 58-63, setembro de 1971.

SHIGA, Naoya. Shiga Naoya Zenshū (Obras completas de Shiga Naoya), Tóquio, Iwanami Shoten. 1955. 15 volumes.

Kinosaki ni te (Em Kinosaki), in: Kozō no Kamisama Ta Jippen, Tóquio, Iwanami Shoten, 1928, p. 108-117.

SHIMAKI, Kensaku. Seikatsu no Tankyū (A Busca da Vida), in: Nihon Gendai Bungaku Zenshū 80 Takeda Rintarō, Shimaki Kensaku Shū. Edição revista e ampliada. Tóquio, Kōdansha, 1980, 232-338.

SHIMAO, Toshio. Ie no naka (Dentro de casa), in: Shimao Toshio Zenshū Dai 5 kan.

Tóquio, Shōbunsha, 1980, p. 326-349.

SHIMAUCHI, Keiji. Utatane (Utatane), Revista Kokubungaku Kaishaku to Kanshō, n.792, maio de 1997.

SHIMAZAKI, Tōson. Haru (Primavera) Nihon no Bungaku 6 Shimazaki Tōson I Tóquio, Chūō kōronsha, 1964, p.271 a 443. Ie (Família), in: Gendai Nihon Bungaku Kan 10 Shimazaki Toson I. Tóquio, Bungei Shunjū, 1967. p. 231-505.

SHINMURA, Izuru (org.). Kōjien(Dicionário Kōjien) 2. ed. revista e ampliada, Tóquio, Iwanami Shoten, 1980.

SŌMA, Tsuneo. Kaisetsu (Explicação), in: Futon; Ippeisotu. 71. ed. Tóquio, Iwanami Shoten, 1995, p. 111-117.

SUZUKI, Kazuo. Nihon Bungaku Shinshi Kodai II (Nova História da Literatura Japonesa Era Antiga II), Tóquio, Shibundō, 1989.

SUZUKI, Tomi. Narrating the self. Fictions of Japanese Modernity. Stanford, Stanford University Press, 1996.

SONOJI, Fumiko \& SUZUKI, Kazuo. Zenkô Izumi Shikibu Nikki. (Curso Geral sobre o Diário de Izumi Shikibu), ed. revisada e ampliada, Tóquio, Shibundō, 1973.

STAM, Roberto. BakhtIn: da Teoria Literária à Cultura de Massa. Tradução de Heloísa Jahn, São Paulo, Ática, 1992. 104 p.

SÜSSEKIND, Flora. Literatura e Vida Literária - Polêmicas, Diários \& Retratos. 2. ed. revisada, Belo Horizonte, Editora UFMG, 2004.

TADIÉ, J. Y. A crítica literária do século XX. Rio de Janeiro, Bertrand do Brasil, 1992.

TADOKORO, H. Watakushi Shōsetsu to Dentō Bungaku to no Kankei - Nikki, Zuihitsu ni tsuite (O Romance do Eu e a Relação com a Literatura Tradicional - sobre o Diário e o Ensaio) Revista Kokubungaku Kaishaku to Kyōzai no Kenkyū, v. 11, n. 3. p.74-80, março de 1966.

TAKAGI, Ichinosuke. Nihon Bungaku no Rekishi. (História da Literatura Japonesa), Tóquio, Musashino Shoin, 1967.

TAKADA, Mamoru. Santō Kyōden (Santō Kyōden), in: ISHIDA, Ichirō (org.). Nihon Bunkashi Gairon. Tóquio: Yoshikawa Hirofumikan, 1968, p. 94-100.

TAKAMI, Jun. Kokyū Wasureubeki (Não se Deve Esquecer a Terra Natal), in: 
Nihon Bungaku Zenshū 65 Takami Jun Shū. Tóquio, Shūeisha, 1968, p.25168.

TAKAHASHI, Hideo. Gendai Sakka Ron (Teoria sobre os Escritores Contemporâneos), Tóquio, Kōdansha, 1979, 327 p.

TAKEDA, Masahiko \& KAWABATA, Kaori (org.), Kihon Bungei Yōgo Jiten. Tóquio, Kōchiku Shuppan, 1980.

TAYAMA, Katai. Futon (Edredon), in Futon / Ippeisotu. 71. ed. Tóquio: Iwanami Shoten, 1995, p. 5-84.

Shōjo Byō (Doente por Meninas), p. 64-71.

TCHÉKHOV, Anton. A Gaivota. Tradução de Rubens Figueiredo, São Paulo, Cosac\&Naify, 2004. 111p.

As Três Irmãs; O Jardim das Cerejeiras. 4. ed. Tradução de GaborAranyi. São Palo, Editora Veredas, 2005, 135p.

TŌGŌ, Katsumi. "Otogizōshi” no Momo Genkyō (Origens de Momo em Otogizōshi), in: Nihon Bungaku Kenkyū Shiryō Sōsho. Dazai Osamu II. Tóquio, Yūseidō, 1985, p. 210-225.

TOKUDA, Shūsei. Ara Shotai (Nova Família), in: Gendai Nihon Bungaku Zenshū 10 Tokuda Shūsei Shū. Tóquio, Chikuma Shobō, 1955, p. 5-29.

Furo Oke (Banheira), in: Gendai Nihon Bungaku Zenshū 10

Tokuda Shūsei Shū. Tóquio, Chikuma Shobō, 1955, p. 171-3.

Kabi (Bolor). Nihon no Bungaku 9 Tokuda Shūsei I. Tóquio, Chuō Kōronsha, 1967, p. 172 a 288

TORII, Kunio. Sengo ni okeru Watakushi Shōsetsuteki Ishiki - Shino Toge o chūshin ni (Consciência sobre o Romance do Eu no Pós-guerra - em torno a Espinho da Morte). Revista Kokubungaku Kaishaku to Kyōzai no Kenkyū, v. 11, n.3, p.53-58, março de 1966.

Kindai Sakka ni Miru "Watakushi”, Dazai Osamu to Itō Sei ( O "Eu” nos Escritores Modernos, Dazai Osamu e Itō Sei). Revista Kokubungaku Kaishaku to Kanshō, v. 36, n.10 Kindai Bungaku ni okeru "Watakushi", p.96101, setembro de 1971.

Dazai Osamu ni Okeru Bungaku Seishin no Keisei. In: Nihon Bungaku Kenkyū Shiryō Sōsho. Dazai Osamu. 3a. ed. Tóquio, Yūseitō. 1972. P. 19-29.

TSUSHIMA, Michiko. Sōgeishaban 'Dazai Osamu Zenshū' Kōki.(Posfácio das Obras Completas de Osamu Dazai da Editora Sōgei), in: Nihon Bungaku Kenkyū Shiryō Sōsho Dazai Osamu, 3. ed, Tóquio, Yūseidō, 1972, p. 238-

261.

UCHIDA, Yasuo \& ISHIZUKA, Hideo. Shakaijin no tame no Kokugo Hyakka (Enciclopédia de Japonês para Adultos.) ed. Rev. Toquio,Taishūkan Shoten, 2001.

UNO, Kōji. Kareki no Aru Fūkei. (Paisagem com Árvores Secas), in: Gendai Nihon Bungaku Zenshū 32 Hirotsu Kazuo, Uno Kōji Shū. Tóquio, Chikuma Shobō, 1955, p. 240-251.

"Watakushi Shōsetsu"Shiken (Minha visão sobre o "Romance do Eu"), Revista Shinchō, outubro de 1925. 
USUI, Yoshimi. Shinkyō Shōsetsu to Tsūzoku Shōsetsu, in: Chikuma Sōsho Taishō Bungakushi, Tóquio, Chikuma Shobō, 1963, p.198-210.

USUTA, K. et al. Ōcho Nikki (Diários do Periodo Imperial), in: Nihon Koten Kanshō Kōza 6 (Curso de apreciação da literatura clássica japonesa),13. ed. Tóquio, Kadokawa, 1969.

WADA, Kingō. Watakushi Shōsetsu Sakka ni okeru Geijutsu to Jisseikatsu (A Arte e a Vida Real nos Escritores do Romance do Eu). Revista Kokubungaku Kaishaku to Kyōzai no Kenkyū. v. 11, n. 3. p.93-98, março de 1966.

WAKIZAKA, Geny. Sobre o Makura Kotoba, Revista Estudos Japoneses 2. p. 2331,CEJ-USP, 1982. Hucitec, 1992. . Man'yôshûu - Vereda do Poema Clássico Japonês. São Paulo,

A poética de Kokin Wakashû, Revista Estudos Japoneses, n. 17. CEJ-USP, p.55-70, 1999.

WATABE, Yoshinori. Dazai Osamu Ron - Chūki o Chūshin to Shite. (Teoria sobre Osamu Dazai - Fase Intermediária), in: Nihon Bungaku Kenkyū Shiryō Sōsho Dazai Osamu II. Tóquio, Yūseitō, 1985, p.27-68.

WATT, Ian. A ascensão do romance, estudos sobre Defoe, Richardson e Fielding. Tradução de Hildegard Feist, São Paulo, Companhia das Letras, 1957.

WELLEK, René \& WARREN, Austin. Teoria da Literatura. Tradução de José Palla e Carmo, 2.ed. Lisboa, Publicações Europa-América, 1962, 382 p.

WHITE, Hayden. O Texto Histórico como Artefato Literário. In: Trópicos do Discurso, Ensaios Sobre a Crítica da Cultura. São Paulo, Edusp, 1994, p. $97-$ 116.

YAMAMOTO, Kenkichi. Kanbayashi Akatsuki, in: Gendai Nihon Bungaku Zenshū, Takii Kōsaku, Tonomura Shigeru, Ozaki Kazuo e Kanbayashi Akatsuki Shū. Tóquio, Chikuma Shobō, 1955, p. 400-406.

Masamune Hakuchō, in: Nihon Bungaku Zenshū 11 Masamune Hakuchō Shū, 4. ed. Tóquio, Shūeisha, 1972, p. 403-432.

YANAGI, Tomiko. Shayō ni tsuite. - Dazai Osamu no Cheehofu Juyō o Chūshin ni. (Sobre Pôr-do-Sol - A recepção de Tchekhov em Osamu Dazai), in: Nihon Bungaku Kenkyū Shiryō Sōsho Dazai Osamu 3. ed. Tóquio, Yūseitō, 1972. p. 166-176.

YANAGITA, Tomotsune. Dazai Osamu no Bunshō (O Texto de Osamu Dazai), in: Nihon Bungaku Kenkyū Shiryō Sōsho. Dazai Osamu. 3.ed. Tóquio, Yūseidō. 1972. P. 213-218.

YASUOKA, Shōtarō. Inki na Tanoshimi (Prazer Sombrio), in: Gendai nihon no bungaku 45 Yasuoka Shōtarō, Endō Shūsaku Shū. Tóquio, Gakushū Kenkyūsha, 1971, p. 133-140.

YOSHIDA, Luiza N. Aspectos do Grotesco Presentes em Konjaku Monogatari e Uji Shûi Monogatari, Revista Estudos Japoneses, n.11, CEJ-USP, p . 59-71, 1991.

. A Época Clássica Japonesa e suas Manifestações Literárias,

Revista Estudos Japoneses, n. 19, CEJ-USP, p.59-75, 1999.

YOSHIDA, Hiroo. Watakushi Shōsetsu no Keifu - sono Seikaku to Hōkō (A 
Linhagem do Romance do $\mathrm{Eu}$ - sua Natureza e Futuro). Revista Kokubungaku Kaishaku to Kyōzai no Kenkyū. v. 11, n.3, p. 65-71, março de 1966.

YOSHIDA, S. Katai Bungaku no Honshitsu, in Meiji Bungaku Zenshû 67 Tayama Katai Shū. Tóquio, Chikuma Shobō,1968, p.367-374.

YOSHIDA, Seiichi. Nihon Bungaku Kanshō Jiten - Koten Hen, 25. ed. Tóquio, Tōkyōdō Shuppan, 1991.

31.ed.__— Kindai Hen,

YOSHIYUKI Jun'nosuke. Shokutaku no Kōkei (Cenário de uma Mesa de Refeição), in: Shinchō Nihon Bungaku 53 . Tóquio, Shinchōsha, 1970 p.375-379.

ZOLA, Emile. Do romance. São Paulo, Imaginário, Edusp, 1995.

\section{ACESSOS À INTERNET PARA ANEXOS}

http://images.google.com.br/images?q=yugao\&hl=pt-BR\&btnG=Pesquisar+imagens. Acesso: em 17 jun 2006

http://images.google.com.br/images?svnum=10\&hl=pt-

$\mathrm{BR} \& \mathrm{lr}=\& \mathrm{q}=$ tukimiso \&btnG=Pesquisar Acesso em: 17 jun 2006

http://images.google.com.br/images?svnum=10\&hl=pt-

$\mathrm{BR} \& 1 \mathrm{r}=\& \mathrm{q}=$ kamon+tomoe\&btnG $=$ Pesquisar Acesso em: 17 jun 2006

http://images.google.com.br/images?q=tsukimiso\&svnum=10\&hl=pt-

BR\&lr $=\&$ start $=20 \& s a=N$ Acesso em: 17 jun 2006

http://images.google.com.br/images?svnum $=10 \& \mathrm{hl}=\mathrm{pt}-$

BR\&lr $=\& q=$ Oenothera + Lamarckiana Acesso em: 17 jun 2006

http://images.google.com.br/images?svnum $=10 \& \mathrm{hl}=\mathrm{pt}-$

$\mathrm{BR} \& \mathrm{lr}=\& \mathrm{q}=$ Oenothera + tetraptera\&btnG $=$ Pesquisar Acesso em: 17 jun 2006

www.otomiya.com/ kamon/kika/tomoe/14.gif Acesso em: 17 jun 2006

http://www.otomiya.com/kamon/kika/tomoe.htm acesso em 17 jun 2006

www.harimaya.com/.../ kaku_ken/mon/tomoe_ji.jpg Acesso em 17 jun 2006

http://images.google.com.br/images?q=tsukimiso\&svnum=10\&hl=pt-

$\mathrm{BR} \& 1 \mathrm{r}=\& \mathrm{star} \mathrm{t}=0 \& \mathrm{sa}=\mathrm{N}$. Acesso em: 17 jun 2006 


\section{APÊNDICE \\ A PROSA JAPONESA E AS INFLUÊNCIAS ESTRANGEIRAS}

Neste apêndice será apresentado, de modo panorâmico, o desenvolvimento peculiar da literatura japonesa, que ocorreu à parte do modelo ocidental, sobretudo em torno das formas literárias em prosa, sob a influência da cultura chinesa, até o final do isolamento do Japão no final do século XIX e, em seguida, o novo processo de formação do mundo literário japonês com a introdução das literaturas européia e norte-americana. O objetivo é situar o Romance do $\mathrm{Eu}$, objeto de nosso estudo, que criou formas próprias como produto cultural e histórico nascido no início do século $\mathrm{XX}$, mantendo como base características próprias da literatura japonesa cultivada até então.

\section{As influências chinesas}

Sabe-se que o intercâmbio com o continente chinês e a península coreana já existia desde o século I - fato comprovado pela existência de um sinete de ouro do Imperador Kōbu, da dinastia Gokan (25-220), que foi recebido pelos emissários que um dos "Estados" japoneses do norte da ilha de Kyūshū enviara à China - e que o Japão, inclusive, já recebia chineses e coreanos que nele fixaram residência a partir dos séculos IV e V.

A adoção consciente da cultura chinesa sob a forma do envio de japoneses com a finalidade específica de estudar essas culturas mais avançadas para desenvolver o Japão e manter relações diplomáticas com a China foi, no entanto, iniciativa de Shōtoku Taishi, o Príncipe regente da Imperatriz Suiko. Em 607, ele iniciou o envio de japoneses a Zui, nome da dinastia chinesa da época; o Japão continuou o intercâmbio até 894 , quando foi abolido.

Com essas comitivas compostas por estudantes e religiosos, que perfizeram cerca de quinze viagens durante as dinastias Zui e Tang à China, o Japão é organizado política e administrativamente com a ajuda de chineses e coreanos, que também foram recebidos para implantar novas técnicas nas mais diversas áreas. Tais 
importações geraram inovações na cultura, na indústria e na tecnologia, e por extensão no pensamento e na religião, com a introdução da fórmula do budismo originário da Índia aclimatado na Ásia Central, China e Coréia, da ética confucionista e da filosofia Roso. A crença Ying-Yang do modelo taoísta e o xamanismo coreano contribuíram para dar forma ao xintoísmo primitivo, que ainda permanecia na esfera da religião natural.

Todas as novidades, contudo, passaram pela devida adequação ao pensamento e às tradições japonesas. Esses aspectos diferenciados podem ser vistos em vários setores. O primeiro exemplo é o sistema político-administrativo Ritsuryō, um tipo de código penal e civil, que teve que eliminar alguns cargos desnecessários entre os oito ministérios e instituir outros inexistentes no sistema. Mesmo assim, esse sistema político-administrativo logo passou por modificações e reformulações para ser mantido e no final, serviu para criar a hegemonia do Clã Fujiwara, que ocupou o centro do governo nas funções de Tutor e Conselheiro, retirando o Imperador do poder executivo. Outro exemplo é a capital japonesa Heiankyō, na cidade de Quioto, que seguiu em grande parte o modelo chinês sem, no entanto, deixar de inserir o gosto e as características do próprio Japão. O pavilhão Daigokuden, que servia para as cerimônias oficiais, foi construído segundo padrões chineses, mas o palácio Dairi, que servia de residência do Imperador, seguiu os padrões japoneses.

$\mathrm{O}$ mesmo fenômeno pode ser observado nas primeiras obras literárias. $\mathrm{O}$ Japão, sendo um país ágrafo, produziu essas obras após o contato com a cultura continental chinesa, tomando-lhe de empréstimo a escrita, que já teria entrado muito antes do século V. Durante um longo processo de assimilação do chinês como língua estrangeira e do uso dos ideogramas, vê-se uma adaptação dos mesmos com a criação de regras de leitura para os textos chineses (kanbun) para grafar a língua japonesa de sistema sintático e fonético distinto. Inicialmente, os japoneses leram e redigiram em chinês, como mostram os documentos de teor burocrático, para então desenvolverem uma leitura adaptada à língua japonesa. Foram criadas leituras japonesas conhecidas como kun, para os ideogramas de mesmo significado no chinês, e os fonogramas chamados man'yōgana, para representar os sons do japonês. Para registrar o vernáculo na ordem sintática japonesa, elaborou-se a forma de escrita 
senmyōgaki, com a aplicação da leitura pelo significado ao ideograma e com a inserção das flexões e de outros morfemas gramaticais, com o man'yōgana em tamanho menor no canto inferior direito do ideograma.

Pode-se dizer que mesclas sino-japonesas estiveram presentes durante todo o período de importação dos elementos chineses, pois seria natural que a influência das poucas pessoas que retornavam da China ficasse restrita a um pequeno grupo da elite japonesa que sua propagação ocorresse de modo mais lento e que seu aproveitamento sofresse adequações que preservaram diversos elementos japoneses.

\section{As primeiras obras escritas}

A literatura japonesa criou formas literárias próprias por volta do século VIII, à parte do conhecido desenvolvimento da literatura ocidental com origem na poesia épica e lírica da antiga Grécia. Da mesma maneira, ela não seguiu os movimentos literários, como o Arcadismo, o Romantismo, o Realismo e o Modernismo. Na prosa, algo semelhante irá ocorrer somente após o contato com a literatura ocidental, iniciado em fins do século XIX.

Partir-se-á, então, do primeiro grande momento histórico que influenciou a arte literária japonesa, ou seja, o período que antecede o século IX, quando o Japão passou a ter os primeiros contatos com a cultura chinesa e resolveu introduzi-la de modo consciente, enviando estudantes e religiosos para a corte chinesa de Zui e Tang e contratando especialistas chineses e coreanos para atuar em diversas áreas de conhecimento para o desenvolvimento do país. Os primeiros contatos com a cultura chinesa continental resultaram nas chamadas culturas Asuka, Hakuhō e Tenpyō, entre os séculos VII e VIII.

Dessa maneira, sob a influência da cultura chinesa e a ajuda da escrita chinesa, os primeiros registros escritos da literatura japonesa surgem com obras de teor histórico-literários e geográficos, coletâneas de poemas japoneses e de poemas chineses e teorias poéticas, das quais podem ser mencionadas como mais representativas Kojiki (Registro de fatos antigos); Nihonshoki (as Crônicas do 
Japão); Fudoki (os Registros de costumes); Kaifūsō (a Coletânea de poemas chineses) Manyō'shî (a Coletânea de poemas de mil folhas) e Kakyō Hyōshiki (Os apontamentos poéticos), que serão abordadas nos parágrafos seguintes. Kojiki, obra concluída em 712, foi escrita em chinês modificado, hentai kanbun, uma mistura das leituras chinesas e japonesas dos ideogramas. A exceção foi a introdução redigida em chinês, kanbun, e os antropônimos e os poemas, em manyō'gana.

Empossado em 672, o Imperador Tenmu incumbiu Hieda no Are (?-?) de pesquisar e organizar a genealogia da família imperial e os registros das sucessões ao trono (Teiki), bem como de uniformizar a mitologia, as lendas e histórias transmitidas dentro e fora da corte (Honji). Vinte e cinco anos mais tarde, o Imperador Genmei deu continuidade ao empreendimento de Tenmu designando Oo no Yasumaro (? -723) para registrar os estudos de Hieda. Elaborado em três volumes, o primeiro deles conhecido como O Volume da Era das Divindades, é composto pela introdução e pelas lendas que começam com o início da criação do céu e da terra e vão até o nascimento de Jinmu, considerado o primeiro dos imperadores. O segundo e o terceiro volumes são conhecidos como Os Volumes da Era dos Homens. O segundo registra o período entre 660 a C. e 313 d.C. e traz a genealogia da casa imperial e as lendas desde o primeiro Imperador Jinmu até o $15^{\circ}$, Imperador Ōjin, e o terceiro volume, entre 313 e 628 do $16^{\circ}$ Imperador Nintoku até a $33^{\mathrm{a}}$ geração, que corresponde à da Imperatriz Suiko.

Cogita-se que o conteúdo do primeiro volume tenha sido escrito por volta do século VI para legitimar o poder político do imperador, e grande parte dos registros mais novos posteriores ao século VI teve por base os registros históricos. Sua elaboração mostra um fio condutor que enfatiza o princípio de monarquia hereditária com origem na divindade ancestral, peculiaridade esta distinta do pensamento político chinês que acredita no poder revolucionário de um escolhido dos céus para tomar o lugar de um governante inadequado.

O Kojiki possui também um grande número de poemas que seguem a tradição oral com temas como a luta, o amor, o encômio e o divertimento, e apesar da falta de uniformidade métrica a maioria é uma espécie de cantiga em versos de 3 e de 4 sílabas cheios de musicalidade, resultante das repetições e dos pares de oposição. Em 
conjunto com os poemas que compõem a obra Nihonshoki, eles formam o Kikikayō (Grupo de Poemas do Registro e das Crônicas), num total de aproximadamente 190 composições poéticas se desconsideradas as que se repetem nas duas obras.

A obra Nihonshoki - segundo a história da literatura japonesa, a primeira das seis crônicas produzidas por ordem imperial conhecidas pelo nome de Rikkokushi (Seis Crônicas Nacionais) - foi concluída em 720 por ordem imperial e teve vários organizadores, mas os principais são o Príncipe Toneri (676-735) e Ō no Yasumaro. Composta por 30 volumes, foi baseada em documentos escritos sobre diversos assuntos, entre os quais a genealogia da família imperial, as lendas, os registros de família de diversos clãs e a origem dos templos e dos santuários. Os dois primeiros volumes concentram-se nas lendas, e os demais registram os feitos dos imperadores desde Jinmu, o primeiro, até Jitō, o $41^{\circ}$. Contudo, os fatos históricos confiáveis são apenas os posteriores a Ōjin e Nintoku. A obra foi redigida em chinês e em ordem cronológica, segundo os modelos dos livros de história da China, com o intuito de afirmar a soberania nacional do Japão perante os países estrangeiros, em especial a China.

Os seis livros que contam a história nacional conhecidos como Rikkokushi ( as Seis Crônicas Nacionais) são Shokunihongi, de 794, que vai do $42^{\circ}$ Imperador Monmu ao $50^{\circ}$ Imperador Kanmu; Nihon Kōki, de 840, com início no $50^{\circ}$ e término no $53^{\circ}$ Jun'na; Shoku Nihon Kōki, de 869, que registra o reinado do $54^{\circ}$ Imperador Ninmyō; Nihon Montoku Tennō Jitsuroku, de 879, do 55 Imperador Montoku; Nihon Sandai Jitsuroku, de 901, que abrange do $56^{\circ}$ Imperador Seiwa ao $58^{\circ}$ Imperador Kōkō.

Portanto, apesar da proposta de apresentar a história do Japão tendo por modelo os livros de história da China, o Kojiki e as Nihonshoki revestem-se de um teor ficcional, com objetivos políticos, que insere os fatos temporais imprecisos em ordem cronológica; observa-se, desde essa época, um esforço de niponizar a grafia chinesa.

Outra obra encomendada por ordem do Imperador Genmei em 713 foi o Fudoki, uma pesquisa geográfica que as diversas regiões japonesas deveriam elaborar sobre seus produtos, a situação das terras aradas, a origem dos topônimos e 
as lendas locais para ser oferecida ao Imperador quando concluída. Restaram apenas cinco, de Harima, Hitachi, Bungo, Bizen e Izumo, que correspondem, respectivamente, às atuais províncias de Hyōgo, Ibaraki, Ōita, Saga e Shimane, sendo o Izumo no Kuni Fudoki (Registro de Costumes de Izumo) datada de 733 o único completo.

Os primeiros registros históricos e geográficos foram produzidos por ordem imperial, ao passo que o poema japonês tem origem na tradição oral. Ligados à crença no poder das palavras (kotodamashinkō), surgiram os ritos (jushi), do qual fazem parte as orações (norito), as palavras de felicitações dirigidas ao Imperador (yogoto) e os éditos imperiais escritos no vernáculo (senmyō), que se desenvolveram para letras de cantigas com composições rítmicas e se consolidaram como canções $(k a y \bar{o})$. É digno de se observar que estas foram utilizadas no evento anual da época conhecido pelo nome de "Cercado de poemas" (utagaki), no qual homens e mulheres se reuniam para desfrutar dos poemas e da dança e revelar seu amor.

Pertencem também à tradição oral as lendas (shinwa) oriundas da crença nas divindades que dominavam a Natureza e nos "causos" (setsuwa), centradas nas narrações sobre a história dos clãs e dos ancestrais.

A primeira antologia de poemas chineses, Kaifūsōo (Reminiscências da China) — única que restou das que se diz terem existido —, foi produzida no Japão em 751 e contém aproximadamente 120 composições de 64 poetas provenientes da classe dominante, ou seja, dos intelectuais, da nobreza e dos religiosos. A literatura japonesa considera que os poemas dessa obra são pobres em criatividade, e a maioria foi elaborada conforme o modelo dos poemas antigos, com 5 sílabas, produzidos na época das seis dinastias (rikuchō) da China, ou seja, entre 220 e 588.

A Coletânea de Poemas Manyō'shū, o mais antigo registro coletivo de poemas japoneses, concluído por volta de 760, compartilha de 28 dos 64 poetas da obra Kaifūsō e teve vários compiladores, dentre os quais Ōtomo no Yakamochi (717?-785). Geny Wakisaka, dedicou um estudo sobre essa coletânea que pode ser conhecido em Man' yōshū - Vereda do Poema Clássico Japonês publicado em português em 1992. Existiram outras antologias anteriores ao Man'yōshū, de natureza privada, como a Coletânea de Poemas de Kakinomoto no Ason Hitomaro, 
elaborada por volta de 700, e a Coletânea de Poemas de Kasa no Ason Kanamura. Com a forma original provavelmente elaborada antes da Era Nara, que começou no século VII, e os dois primeiros tomos, no início da mesma Era, a obra assumiu a atual forma, composta por 20 tomos com cerca de 4500 poemas, após várias edições ampliadas. Supõe-se que posteriormente ainda possa ter passado por algumas revisões.

Com exceção das canções transmitidas desde eras antigas, reúne poemas que abrangem um período de mais de 130 anos, compostos por pessoas provenientes das mais diversas camadas sociais, desde o Imperador e a família imperial até autores desconhecidos da camada popular, que utilizam temas variados como o amor, os encômios, as estações do ano e as viagens. A maioria dos poemas possui versos que seguem a métrica de 5 e 7 sílabas. Cerca de $90 \%$ dos poemas são elaborados na forma do poema curto tanka $(5,7-5,7-7)$, e os demais em outras variantes conhecidas pelo nome de poema longo chōka (5, 7-5, 7...5, 7-7), katauta (5, 7-5), sedoka $(5,7-7,5,7-7)$ e bussokusekika $(5,7-5,7-7,7)$. Utilizam os recursos estilísticos do makurakotoba, palavra composta geralmente por 5 sílabas, que serve para introduzir determinado termo, metaforizando-o, e do jokotoba, formado por termos de extensão indefinida que atraem também outros termos, por uma relação semântica ou fonética. Nota-se ainda que os poemas longos recorrem muito aos pares de oposição e às repetições.

O surgimento de um grande número de poemas japoneses reunidos numa antologia da dimensão do Man'yōsh ū quase imediatamente após a primeira coletânea de poemas chineses demonstra que, paralelamente ao esforço de imitar a poesia chinesa, houve uma elaboração artística fundamentada no sentimento do povo japonês, que reproduziu as mais profundas emoções em sua própria língua, auxiliada pela recém-introduzida escrita estrangeira, já com as primeiras adaptações mencionadas anteriormente.

A última obra a ser apresentada entre as primeiras produções referidas é o mais antigo tratado de poesia, intitulado Kakyō Hyōshiki. Foi escrito por Fujiwara no Hamanari (724-790) em 772 e trata da versificação chinesa aplicada aos poemas 
japoneses, com indicações acerca dos aspectos negativos das composições poéticas da época.

Assim, podemos ver que os primeiros registros japoneses só se tornaram possíveis com a introdução dos conhecimentos adquiridos no continente chinês adaptados à realidade japonesa para trabalhar com a mitologia, as lendas e as histórias da tradição oral. Logo nesse primeiro momento, o Japão utiliza seu potencial tanto no sentido de assimilar as novidades como no sentido de aplicá-las no próprio desenvolvimento, gerando produções resultantes da imitação dos modelos chineses, mas indo além, com a criação de obras que representam as peculiaridades do povo japonês, seja no âmbito da poesia ou da prosa.

Tais elementos encontrados nos primórdios da história da literatura japonesa confirmam a visão de Ienaga Saburō (1968:114) sobre a manutenção da cultura popular tradicional transmitida desde os tempos antigos, apesar da implantação da cultura do continente asiático, e também sobre a manutenção desse impulso cultural, responsável pelo novo desenvolvimento da cultura japonesa a partir do século VII, com a mesma intensidade no século VIII. O estudioso entende que o governo adotou a forma político-administrativa da China e buscou no budismo a solução espiritual para os receios e as preocupações originadas pelas contradições geradas no interior do próprio sistema, e explica que os direitos adquiridos pela aristocracia acarretavam um ônus muito grande para a população. Isso acabou gerando disputas de poder e conflitos no interior da corte. Para ele, o budismo servia, outrossim, como demonstração do poder da nova nação japonesa, não apenas no interior do país como também nos países estrangeiros, por meio da construção de grandes pavilhões e de imagens budistas. Tudo isso só foi possível com a concentração da riqueza material e do controle da mão-de-obra.

No início do século VIII, houve um esforço ainda maior para fomentar o budismo. O ofício religioso que pedia pela segurança do país por meio do poder do sutra Konkōmyō é instituído como evento nacional na época do Imperador Tenmu e Jitō; a partir de 741, são construídos em todas as regiões (kuni) os templos Konkōmyō para a proteção do país, ou seja, os famosos templos de monges Kokubun, e também os templos para eliminação dos pecados por Hōke, isto é, os 
templos de monjas Kokubun. O budismo, na realidade, propaga-se para atender à necessidade política do governo. Os templos mais poderosos recebiam propriedades e terras da corte em troca da proteção religiosa do país, e o budismo deveria atender somente a essas funções religiosas. A divulgação entre a população só terá início com Gyōki (668-749), um dos primeiros bonzos a pregar o budismo nas ruas, seguido por alguns discípulos, a partir da primeira metade do século VIII, que irão preparar o terreno para a propagação dessa crença religiosa entre o povo (entre os séculos XI e XII mantém-se a crença nos sutras e nas orações, até que surja o novo budismo, centralizado no século XIII com Shinran (1173-1262) e Nichiren (12221282)).

O período áureo da cultura influenciada pela dinastia Tang correspondeu à época do Imperador Saga e continuou com resquícios ainda na época de Montoku e Seiwa até Uta e Godaigo. Nas esferas sociais mais elevadas, ela alcançou as leis públicas, a produção de "textos", os cerimoniais e rituais; nas inferiores, a alimentação, a moradia e vestuário da vida cotidiana, os gostos e as diversões. $\mathrm{O}$ estudo da época consistia na aquisição de conhecimento sobre os sutras (Kyōgaku e Myōkyōgaku) com a leitura das obras chinesas Jiga — que explica os termos das doutrinas da China antiga - e Monzen - livro ue classifica detalhadamente os textos e poemas de um período de mil anos a partir da dinastia chinesa Shū (1100 a. C.-256 d. C.) - e na intelecção de livros de história da China, como Shiki, Kanjo e Gokanjo, todos registros históricos chineses.

As figuras representativas dessa época na literatura eram funcionários do governo. Shiki é o primeiro registro histórico oficial que cobre desde o período lendário, há mais de 1500 anos a.C., até o Imperador Bu, nos últimos séculos que precedem a era Cristã. Kanjo, escrito no século I, e Gokanjo, no século V, são continuações do Shiki e apresentam, como ele, uma divisão da história por conteúdo. Houve uma valorização muito grande dos textos, entendidos como literatura e arte literária, imprescindíveis na educação masculina. Várias coletâneas de poemas chineses foram organizadas por ordem imperial, com conteúdos que variavam entre as saídas e passeios do Imperador, diversões, caça esportiva e despedidas. $\mathrm{Na}$ literatura chinesa, os poemas não eram lidos e apreciados como estavam, ou seja, 
com a leitura chinesa. Sua intelecção era realizada procedendo-se a uma tradução do chinês para o japonês. Para a composição dos poemas chineses, certamente ocorria o mesmo, no sentido inverso.

Pode-se concluir, portanto, que não houve uma adoção integral da literatura continental chinesa, muito menos um abandono total das tradições e da língua japonesas. A literatura chinesa passou por um processo de adoção imitativa e de assimilação, ao final da qual surge uma literatura híbrida em que prevaleceram os elementos japoneses.

Nesse contexto, a decadência da dinastia chinesa Tang foi uma grande oportunidade para o Japão, que já apresentava uma forte tendência de manter e preservar a cultura nacional e de começar a criação de uma literatura autóctone. Em termos históricos, Sugawara no Michizane (845-903), que servia ao Imperador Uta, cancela as dispendiosas e arriscadas viagens a Tang em função da decadência dessa dinastia e também das dificuldades econômicas baseadas na distribuição de terras, que foi se tornando impraticável.

Desse modo, objetivou-se apresentar, não apenas no âmbito da prosa, obras que surgiram nesse contexto específico da formação da literatura japonesa, a fim de salientar a importação de elementos estrangeiros, neste caso do continente chinês e da península coreana e, sobretudo, de observarem-se os resultados.

No aspecto formal, foi possível constatar que as primeiras produções consideradas literárias são classificadas, grosso modo, em prosa e poesia. Os registros de caráter histórico recebem tratamento distinto das obras poéticas, mas os poemas são uma presença marcante nas duas primeiras obras históricas, a ponto de merecerem um tratamento à parte como "poemas do Registro e das Crônicas". Tratando-se de registros históricos, é natural que as composições poéticas dos japoneses tivessem sido alvo de preservação tanto do Kojiki quanto do Nihonshoki. No entanto, elas não são apenas inscritas. Os poemas aparecem como composições feitas pelas personagens no momento em que são apresentadas.

É o caso do famoso poema (Yakumo tatsu Izumo Yaegaki tsuma gomi ni yaegaki tsukuru sono yaegaki o), que Susanoo no Mikoto compõe no momento de felicidade, em sua nova residência em Izumo, com a princesa Kushinada, que aceitou 
se casar com ele, tendo sido salva da cobra monstruosa que já havia devorado oito moças; dos poemas ("Yamato wa kuni no mahorobo tatanazuku aokaki yamagomoreru yamato shi uruwashi" e "Sanesashi Sagamu no ono ni moyuru hi no honaka ni tachite toishi kimi wa mo") compostos pelo heróico Yamato Takeru no Mikoto e pelas personagens presentes em seu episódio, como a princesa Ototachibana no Hime no Mikoto, que fazem parte do Kojiki; ou da tristeza do Príncipe Arima no Miko, composta em poema (Ie ni areba ke ni moru ii o kusamakura tabi ni shi areba shii no ha ni moru) na praia de Iwashiro quando é enviado para junto do Imperador, depois de ter sido traído por Soga no Akae que, na noite anterior, lhe havia proposto derrubar o Imperador.

\section{$\mathrm{O}$ desabrochar das novas formas literárias a partir do século $\mathrm{X}$}

O período subseqüente ainda continuou na esteira das primeiras obras durante aproximadamente um século A partir do século X, que coincide com o encerramento das expedições culturais à China em 894 e com o final da importação intencional da cultura chinesa, houve, porém, um aumento e uma diversificação na produção literária, motivada pela invenção de uma nova forma de escrita. Criaram-se denominações e classificações próprias para esse grande número de obras em prosa e em poesia e surgiram reflexões teóricas sobre a literatura, que resultaram em livros de poética e de crítica literária.

A nova escrita em fonogramas (kana) foi desenvolvida entre o final do século IX e início do século $\mathrm{X}$ a partir do já mencionado man'yōgana, ou seja, dos ideogramas usados para representar os vocábulos e os fonemas japoneses.

É possível perceber que a nova escrita começou a ser utilizada primeiro nos poemas, em seguida nos diários literários e, por último, nas narrativas. Cumpre observar que o termo "narrativa" é utilizado de modo amplo na literatura japonesa e serve para designar tanto as obras de cunho histórico como as de natureza literária. Taketori monogatari (Narrativa do Cortador de Bambu), considerada a "ancestral das narrativas", surgiu entre 900 e 902 e ainda foi escrita com os ideogramas 
chineses utilizados em sua leitura adaptada para o japonês (kanbun no kundoku buntai). A primeira obra posterior a ela foi Ise monogatari (Narrativa de Ise), datada de 946, possivelmente em função de sua autoria masculina, o poeta Ariwara no Narihira. Já o Diário Literário que fez uso dos fonogramas em kana teve sua primeira obra, Tosa Nikki (Diário de Tosa), escrita por volta de 935 pelo renomado poeta Ki no Tsurayuki (870-945). Kokin Wakashū (Coletânea de Poemas Waka de Outrora e de Hoje) foi elaborada ainda mais cedo, entre 905 e 913.

$\mathrm{O}$ uso do fonograma propiciou novo impulso à literatura, gerando um grande número de obras produzidas especialmente pelas mulheres, sobretudo pelas damas da corte. Pode-se dizer que a literatura feminina desse período esteve intimamente ligada ao sistema político centralizado nos Tutores e Conselheiros, no qual eles garantiram a manutenção do poder em suas mãos casando suas filhas com o Imperador. Aliado ao sistema poligâmico para os homens vigente na época, que serviu de mola propulsora para tamanha produção expressiva da literatura feminina, é possível notar que as grandes obras literárias desse momento histórico são de responsabilidade quase total das mulheres. Criadas e instruídas com o máximo de zelo para servirem na corte e tornarem-se futuras esposas do Imperador, elas gozavam inclusive de privilégios até maiores que os homens dentro da família.

Esse período é conhecido como a fase de distanciamento da cultura do continente e de criação de uma cultura japonesa propriamente dita. A escrita hiragana é produto dessa elaboração e se estabelece pelas mãos das mulheres instruídas da corte Heian. Akiyama (1974) diz que os japoneses começam a ter o domínio da expressão escrita manifestando livremente seus sentimentos e pensamentos por meio da escrita hiragana, mas os homens demoraram a se desvencilhar dos textos estrangeiros escritos em chinês.

\section{Poesia}

Depois da primeira coletânea, Kaifūsō, os poemas chineses atingiram o período áureo no século IX com as três antologias compiladas por ordem imperial Coletânea Ryōun Shinsh̄̄, de 814, obra em volume único com 91 poemas 
compilados por Ono no Minemori, Sugawara no Kiyotomo, Isayama no Fumitsugu e outros, por ordem do Imperador Saga; Coletânea Bunka Shūreishū, de 818, com 148 poemas organizados por temas em três volumes por Fujiwara no Fuyutsugu, Sugawara no Kiyotomo, Isayama no Fumitsugu e outros compiladores, também segundo ordem do Imperador Saga e Coletânea Keikokushū, de 827, com poemas de 178 pessoas organizada em 20 volumes por Yoshimine no Yasuyo, Minabuchi no Hirosada, Sugawara no Kiyotomo e outros compiladores, por ordem do Imperador Jun'na -, e outras antologias particulares de poemas chineses - Coletânea Shōryōshū, de 840, da autoria de Kūkai; antologia Kanke Bunsō, de 900; e Kanke $K \bar{o} s h \bar{u}$, de 903, da autoria de Sugawara no Michizane - e uma poética chinesa obra intitulada Bunkyōhifuron, de 820, na qual Kūkai coligiu os estudos lingüísticos da China e sistematizou as regras de composição do poema chinês. No início do século $\mathrm{X}$, contudo, os poemas chineses foram se tornando cada vez menos expressivos e acabaram saindo do cenário literário japonês no início do século XI, para reaparecerem no século XIV entre o círculo restrito dos monges zen-budistas de Gozan, em Quioto, que recebiam a proteção do Governo Militar de Muromachi. Voltaram a ser produzidos pela última vez no século XVII, pelos estudiosos e pesquisadores japoneses do Confucionismo e dos estudos chineses, e permaneceram até a ocidentalização e modernização do Japão, no século XX, para então desaparecerem do panorama literário japonês.

Após as três coletâneas compiladas por ordem imperial no século IX, os poemas japoneses waka (ou yamato uta), que haviam sido superados pelos poemas chineses desde o século VIII, quando foi elaborada a coletânea de poemas Man'yōshū, voltaram a assumir de modo gradativo a posição dominante a partir da segunda metade do século IX. Além da facilidade proporcionada pela escrita em fonogramas, eles começaram a ganhar força com as Reuniões Poéticas, que se tornaram os centros das atrações da aristocracia. Nesses embates literários era avaliado o talento poético para a composição imediata dos poemas waka mediante uma tarefa proposta, e o resultado dessas ricas produções foi compilado em coletâneas como Minbu gyōke utaawase, de 885; Kanpyō no oontoki Kisai no miya 
utaawase, de 893; e Teino no In no utaawase, de 913, as mais representativas dessa época e que levam o nome das reuniões poéticas.

Ajudado pela escrita fonogramática, o poema japonês assumiu a posição dominante na literatura palaciana. Na introdução de Kokin Wakashū — primeira antologia poética organizada por ordem imperial em 905, com cerca de 1100 poemas produzidos pela classe nobiliárquica, dentre eles 450 de autores anônimos , Ki no Tsurayuki, um de seus organizadores, apontou o nome dos seis poetas mais brilhantes - Ariwara no Narihira, Sōjō Henjō, Ono no Komachi, Fun'ya no Yasuhide, Monje Kisen e Ōtomo no Kuronushi — do início do século X e a predominância da forma poética waka em 31 sílabas. Diante da necessidade de adotar critérios estéticos e estilísticos, teorias poéticas foram produzidas pelos elaboradores das coletâneas e das antologias e pelos juízes das Reuniões Poéticas.

Ao lado de muitas coletâneas particulares, foram compiladas por ordem imperial, 21 grandes coletâneas de poesia waka conhecidas pelo nome de Nijūichidaishū que contaram com a participação de poetas e poetisas de notoriedade. São elas:

1. Kokin Wakashū (Coletânea de Poemas Waka de Outrora e de Hoje), 905 (ordem) - \pm 913 (entrega ao imperador)

2. Gosen Wakashū (Coletânea de Poemas Waka Escolhidos), 951

3. Shūi Wakashū (Coletânea de Poemas Waka Reunidos), \pm 1005

4. Goshūi Wakashū (Coletânea de Poemas Waka Reunidos II), 1086

5. Kin'yō Wakashū (Coletânea de Poemas Waka Folhas de Ouro), 1127

6. Shika Wakashū (Coletânea de Poemas Waka Palavras Poéticas), 1151

7. Senzai Wakashū (Coletânea de Poemas Waka Infinidade), 1186

8. Shinkokin Wakashū (Nova Coletânea de Poemas Waka Outrora e de Hoje), 1201(ordem) - \pm 1210 (conclusão)

9. Shinchokusen Wakashū (Nova Coletânea de Poemas Waka por Ordem Imperial), 1235

10 Shokugosen Wakashū (Coletânea de Poemas Waka Escolhidos - Continuação), 1251 
11. Shokukokin Wakashū (Coletânea de Poemas Waka Outrora e de Hoje Continuação), 1265

12. Shokushūi Wakashū (Coletânea de Poemas Waka Reunidos - Continuação), 1278

13. Shingosen Wakashū (Nova Coletânea de Poemas Waka Escolhidos), 1303

14. Gyokuyō Wakashū (Coletânea de Poemas Waka Folhas Preciosas), 1312

15. Shokusenzai Wakashū (Coletânea de Poemas Waka Infinidade - Continuação), 1320

16. Shokugoshūi Wakashū (Coletânea de Poemas Waka Reunidos II - Continuação), 1326

17. Fuga Wakashū (Coletânea de Poemas Waka Requinte), 1349

18. Shinsenzai Wakashū (Nova Coletânea de Poemas Waka Infinidade), 1359

19. Shinshūi Wakashū (Nova Coletânea de Poemas Waka Reunidos), 1364

20. Shingoshūi Wakashū (Nova Coletânea de Poemas Waka Reunidos II), 1384

21. Shinshokukokin Wakashū (Nova Coletânea de Poemas Waka Outrora e de HojeContinuação), 1439

Até o início do século XIII, foram oito grandes antologias conhecidas pelo nome de Hachidaishū, as Oito Grandes Coletâneas de Poemas Waka, entre as quais incluem-se as três primeiras chamadas de Sandaishū, as Três Grandes Coletâneas de Poemas Waka. As demais são chamadas de Jūsandaishū, as Treze Grandes Coletâneas de Poemas Waka, compiladas entre os séculos XIII e XV.

Depois dessa rápida passagem pelo desenvolvimento da poesia no Japão, apresentaremos em blocos as novas formas literárias e suas nomenclaturas, estendendo-os e aprofundando-os mais ou menos em função da pertinência de cada gênero neste trabalho, e logicamente, da dimensão das obras abordadas, com o intuito de dar a conhecer o desenvolvimento dessas formas.

\section{Registro Histórico e Narrativa Histórica}

Inicialmente, as obras históricas continuaram nos mesmos moldes do Nihonshoki, dando continuidade ao registro das eras imperiais a partir do $42^{\circ}$ até o 
$58^{\circ}$ Imperador, e mantiveram uma regularidade em sua produção com cinco obras entre o final do século VIII e início do século IX: Shokunihongi (Nihonshoki continuação. Parte I, 794, e Parte II, 797); Nihon Kōki (Crônicas Posteriores do Japão, 840); Shokunihon Kōki (Crônicas Posteriores do Japão - continuação, 869); Montoku Jitsuroku (Registros Verídicos da Era Montoku, 879); e Sandai Jitsuroku (Registros Verídicos de Três Gerações, 901), que juntamente com Nihonshoki fazem parte dos Rikkokushi (Seis Livros da História Nacional).

É possível considerar esses registros históricos como as primeiras narrativas históricas (ou os primeiros romances históricos) do Japão, seguidas por outras obras criadas em época posteriores, com nomes e classificações diferentes segundo a nomenclatura adotada pela literatura japonesa.

No período seguinte, outras obras que seguem a linha do registro histórico são produzidas sob o nome de Rekishi Monogatari, ou seja, Narrativa Histórica. Fazem parte desse grupo o conjunto de obras conhecido como Shikyō (Quatro Espelhos) constituído por Ōkagami (Grande Espelho, 1086 ou 1115); Imakagami (Espelho do Presente, 1170); Mizukagami (Espelho D’água, 1196) e Masukagami (Espelho Adicional, 1376) —,Eiga monogatari (Narrativas de Glória da Família Fujiwara I e II, 1028-1107), Gukanshō (Excertos Históricos de Jien, 1220) e Jin'nō Shōtōki (Registro da Legitimidade da Linhagem Imperial da Corte do Sul, 1339).

Na Narrativa Histórica, observa-se que Narrativas de Glória da Família Fujiwara, Espelho D’água e Espelho Adicional seguem a ordem cronológica, adotada no Grande Espelho e Espelho do Presente. Os espelhos posteriores ao Espelho do Presente seguem a forma narrativa em diálogos, como ocorre no Grande Espelho.

A Narrativa Histórica tem uma preocupação mais literária que o Registro Histórico, e de um modo geral focaliza uma coletividade representada pela família ou por um grupo, mas algumas apresentam a vida particular de personalidades como Minamoto no Yoshitsune ou dos irmãos Soga que os livros de história literária japoneses consideram exceções. 


\section{Ensaio Literário}

O primeiro Ensaio Literário é Makura no sōshi (Livro de Cabeceira), obra de 1001, da autoria da dama da corte Sei Shōnagon (965?-1025?), que serviu à Imperatriz Teishi e teria sido incumbida por ela de escrever a obra registrando fatos ligados a essa $C h \bar{u} g \bar{u}$ — nome mais utilizado para $H i$ (com origem na família imperial), a mais importante depois da esposa oficial, chamada de Kōgō. Na seqüência, vinham Fujin (portadora do título acima do Grau 3), mais conhecida como Nyōgo, e Hin (portadora do título acima do Grau 5), chamada comumente de $K \bar{o} i$. O termo "sōshi", que significa encadernação, folhas rascunhadas, escritos em kana, e que vai designar diversos tipos de obras em prosa na idade pré-moderna, já aparece na composição do nome dessa obra, intitulada Makura no Sōshi, literalmente "rascunhos do/ao/no travesseiro".

O Livro de Cabeceira registra as observações da autora sobre a vida no Palácio de Trás com grande inteligência, despojamento e humor, mas suas avaliações quase impessoais se restringem a impressões críticas. A obra discorre sobre assuntos relacionados à Imperatriz Teishi em forma de recordações, reúne escritos temáticos sobre a natureza e sobre fatos interessantes (okashi), surpreendentes (susamajiki) e confiáveis (atenaru) e registra observações e impressões sobre a natureza, as pessoas e assuntos variados. Suprime os predicados com muita freqüência e utiliza a forma de associação de idéias na exposição dos assuntos. A obra possui cerca de 300 capítulos. Classificada como ensaio, ou seja, zuihitsu, na realidade é a única que representa esse "gênero" na Idade Antiga, pois o zuihitsu vai ganhar maior expressão a partir do período seguinte.

O ensaio recebeu novo enfoque dentro da Literatura Budista dos Retirados, nos séculos XIII e XIV, e deixou Hōjōki (Registro da Cabana de Nove Metros Quadrados), escrito em 1212 por Kamono Chōmei (1155 ou 1153-1216), e Tsurezuregusa (Anotações no Ócio), de 1331, de autoria de Urabe Kenkō ( \pm 1283 1350). Essas duas obras expressivas compõem a Literatura dos Retirados (Inja Bungaku) ou a Literatura da Cabana (Sōan Bungaku) da Idade Média japonesa. 
Kamono Chōmei discorre sobre a efemeridade e a transitoriedade (mujō) da vida observando as calamidades naturais e humanas que assolaram a capital japonesa e sobre os seus sentimentos vivendo longe da sociedade da qual antes fazia parte e a sua vida na pequena cabana no meio da mata.

O autor de Tsurezuregusa era versado no confucionismo, budismo e taoísmo, e, fundamentado em seu vasto conhecimento, escreveu sobre a natureza e a vida, as lembranças do passado, tecendo críticas e expondo suas teorias dé composta por 243 capítulos. Seu autor um indivíduo muito instruído

\section{Diário Literário}

Inaugurado como novo gênero por Ki no Tsurayuki, com Tosa Nikki (Diário de Tosa), concluído em 935, o Diário Literário costuma ser dividido em diário poético (uta nikki), a partir do qual parece ter se desenvolvido ao registrar lembranças pessoais com os poemas, kotobagaki (as anotações concernentes aos contextos dos mesmos) e diário de viagens (tabi nikki), que posteriormente vêm a constituir a chamada literatura de viagem (kikō bungaku).

Tosa Nikki registra, em kana, a viagem de regresso de um oficial do governo ao término de seu mandato, narrado na terceira pessoa do singular por uma integrante da comitiva com inserções introdutórias e explicativas sobre os poemas que recordam emoções pessoais do passado. Apresenta, assim, características diferentes dos diários burocráticos denominados niki, escritos em chinês pelos oficiais do governo, pelo abandono do estilo típico de registro para conseguir um meio de expressar com maior liberdade os sentimentos pessoais que não lhe seria permitidos registrar como oficial do governo no cumprimento do dever e pelo emprego da voz narrativa feminina, como que justificando o uso dessa forma de escrita e manifestando a vontade feminina de imitar os homens no registro de seus diários.

Essa obra narra a viagem de 55 dias de volta do próprio Tsurayuki e sua comitiva para a capital ao término de seu mandato como governador da Província de Tosa (atual Província de Kōchi). Contém 61 poemas waka, apresentados como composições feitas em diversas situações ao longo da viagem pelos integrantes da 
comitiva, o que imprime uma dose de subjetividade ao texto, num misto de relatos de impressões e emoções demonstradas nas alegrias e nas angústias, nos encantos e decepções, temores e expectativas.

Tosa Nikki apresenta, ainda, a característica de ser um louvor à memória da filha de Ki no Tsurayuki, que não chega a regressar à capital — falece em Tosa —, e também de servir como um tratado poético para os jovens iniciantes do waka, fornecendo modelos de condições para a criação poética, ora motivado por um acontecimento, ora por uma paisagem de grande beleza.

Após essa primeira obra inaugural de Ki no Tsurayuki, os próximos diários foram produzidos por mulheres da aristocracia, com certeza pela invenção da escrita em fonogramas e pelo clima propício do já mencionado sistema de governo centralizado no Tutor e no Conselheiro instituído pela Família Fujiwara. No caso de Kaguerō Nikki (Diário do Pirilampo), segunda obra desse gênero, surgida por volta de 974, outros fatores motivaram a autora, conhecida apenas como mãe de Fujiwara no Michitsuna. Considerada uma das três beldades da época, era filha de Fujiwara no Tomoyasu e esposa de Fujiwara no Kaneie. Não se sabe ao certo sua data de nascimento e de morte, mas parece ter vivido até os 60 anos de idade.

Ao iniciar a obra, a autora aponta os motivos que a levaram a registrar as particularidades de sua vida: seu desejo de que a realidade por ela vivida servisse de conforto às mulheres que sofrem o mesmo infortúnio do sistema poligâmico e seu interesse pelas histórias verídicas em detrimento das fabricadas, tão em voga naquele momento; assim, tem início o chamado Diário Literário Feminino.

Composto por três volumes, esse diário de 21 anos tem início em 954 e é narrado em primeira pessoa, seguindo uma ordem cronológica com a inscrição dos dias em que o registro foi feito e com vários poemas que começam com as cartas de amor trocadas com Fujiwara no Kaneie. Nascida numa família da classe dos governadores, a narradora protagonista aceita o insistente pedido de casamento de Kaneie, que já possui ama esposa oficial, e vem a ter Michitsuna. Apesar do sucesso profissional de Kaneie e do desenvolvimento do filho, ela sofre com os relacionamentos amorosos que Kaneie tem com outras mulheres e tenta obter tranqüilidade fazendo peregrinações aos templos Hase e Ishiyama. Por fim, acaba 
desistindo do marido e encontrando a razão de viver no amor maternal pelo filho Michitsuna. É o registro de uma reflexão interior de busca da verdade em meio à realidade que envolve os sofrimentos femininos.

Izumi Shikibu Nikki (Diário de Izumi Shikibu), o segundo diário feminino, surgiu por volta de 1007. Diferentemente do primeiro, foi escrito na terceira pessoa do singular e deixou questionamentos sobre sua autoria e seu gênero. Contudo, os pormenores de sua vida íntima e o enredo centralizado nos poemas de sua autoria focalizando apenas esse episódio da vida da autora fizeram que ele permanecesse na classificação de Diário e não de Narrativa. A obra começa a partir do cortejo amoroso do Príncipe Atsumichi, cunhado da protagonista, que tem início por volta de abril de 1003, pouco depois do período de luto pela morte do Príncipe Tametaka, seu esposo, e narra a vida amorosa da protagonista com o irmão mais novo de seu exmarido, até ser acolhida por ele, 10 meses depois, no ano novo, vencendo todas as oposições e saindo triunfal perante a esposa oficial de Atsumichi, que deixa o palácio quando ela se muda para lá. Em nenhum momento, a autora tem seu nome mencionado e só é identificada poucas vezes como "a dama". O enredo desenvolvese centralizado nos mais de 160 poemas, e por isso também é considerado um diário poético.

Iniciado dessa maneira, o Diário Literário ganha espaço significativo especialmente pelas mãos das mulheres.

Murasaki Shikibu Nikki (Diário de Murasaki Shikibu, \pm 1010 )registra as experiências e impressões de quando Murasaki Shikibu serviu na corte da Imperatriz (Chūgū) Sōshi, esposa do Imperador Ichijō e filha de Fujiwara no Michinaga. Vai do outono de 1005 ao ano novo de 1007. Grande parte insere-se em 1005, quando nasceu o Príncipe Atsunari, futuro Imperador Goichijō. Além de uma parte em forma de diário, com informações sobre o nascimento do Príncipe e acerca da natureza das pessoas que se reuniam no mundo de opulência de Michinaga, há uma parte em forma de recordações, com uma avaliação sobre outras damas da corte, como Izumi Shikibu, Akazome Emon e Sei Shōnagon, uma comparação entre a corte de Senshi e a de outra esposa do Imperador e também uma reflexão pessoal sobre seu próprio modo de viver. Nessa obra, as figuras humanas são expostas em seus aspectos 
negativos, num mundo corrompido pelo orgulho, ambição e falsa modéstia, na qual a autora não encontra lugar.

Murasaki Shikibu começou a servir na corte entre 1005 e 1006, provavelmente com o reconhecimento de Michinaga, pai da Imperatriz Shōshi, pela fama de as Narrativas de Genji, que ela começou a escrever após a morte de seu esposo, Fujiwarano Nobutaka, em abril de 1001.

Midō Kanpaku Ki (Diário do Conselheiro Construtor do Templo que Abriga Buda) de 1021 é o diário de Fujiwara no Michinaga, que registra os anos de 9981021, usando o calendário lunar. Recebeu o nome de Midō Kanpaku porque intitulou-se Conselheiro kanpaku e construiu o Templo Hōsei, ou seja, o templo que abriga Buda. Diz-se que a obra era composta por 30 volumes, mas somente 14 chegaram aos dias atuais.

Escrito pela filha de Sugawara no Takasue (1008 ? -1058) o Sarashina Nikki (Diário de Sarashina, \pm 1060 ) é um registro de cerca de 40 anos da autora, desde a infância até a velhice. Relata a decepção de uma jovem sonhadora com a vida de seus pais, o servir na corte, a vida de casada e o rigor da sociedade. Ela se apóia em Buda e espera pela salvação na vida após a morte. É um retrato da tristeza da vida e dos sonhos depositados no mundo maravilhoso das narrativas.

Jōjin Ajari Haha no Shū (Coletânea da Mãe de Jōjin Ajari, 1073) é uma coletânea de 173 poemas em forma de diário que narram a aspiração pela carreira religiosa de Jōjin quando aos 58 anos pretendia ir à China seguir o caminho budista, e a tristeza de sua velha mãe, com mais de 80 anos, que não quer se separar da filha. Ela parte em 1072 e falece em 1081, sem jamais voltar ao Japão. O registro da obra tem início em 30 de janeiro de 1071 e termina em 1073. A autora é a mãe de Jōjin, neta do então Ministro da Esquerda Minamoto no Takaakira e filha de Toshikata, um dos quatro Nagon da Corte do Imperador Ichijō. Nascida em 988, desconhece-se a data de seu falecimento. Casou-se com um poeta famoso, filho de Fujiwara no Sanekata (provavelmente Yoshikata), e deu à luz, Jōjin e um menino. Logo depois, seu marido falece.

Fujiwara no Nagako, neta da autora do Diário de Kagerō, tornou-se sanuki do Imperador Horikawa em 1101, mas não se sabe sua data de nascimento nem de 
falecimento. Sua identificação "de Sanuki” provém do fato de Akitsuna, seu pai, ter sido governador dessa província. Sanuki no Suke Nikki (Diário de Suke da Província de Sanuki, \pm 1108$)$ é composta por dois volumes, que têm na "morte" seu tema. $\mathrm{O}$ primeiro descreve, em primeira pessoa, o ingresso da autora na corte, centrado em fatos ligados à doença e morte do Imperador Horikawa desde 1107. O segundo registra a subida ao trono do infante Imperador Toba e sua primeira atividade oficial.

Gyokuyō (Belas Folhas, 1200) foi escrito por Kujō Kanezane, que expõe detalhes sobre a realidade política do início do período Kamakura e das famílias Minamoto e Taira.

Kenshümon'in Chūnagon Nikki (Diário de Kenshūmon'in Chūnagon), também conhecido como Tamakiharu ou Kenju Gozen Nikki, é uma obra de 1219 que idolatra Kenshūmon'in, mãe do Imperador Takakura, a quem a autora, filha de Fujiwara no Toshinari, serviu. Diz-se que foi redigida por Teika, irmão mais novo da autora, após sua morte.

Meigetsuki (Registro da Lua de Outono, 1235) é o diário do poeta Fujiwara no Teika, em que ele registra cerca de 36 anos (1180-1235) sobre as relações dos nobres e militares, os costumes sobre os eventos e etiquetas e sobre o poema waka, emitindo opiniões pessoais.

As duas obras Kaidōki (Registro (Diário) do Caminho do Leste, \pm 1231 ) e Tōkanki (Diário de Viagem pela Costa Leste, \pm 1235-1242) parecem ter sido escritas na primeira metade do século XIII por algum homem que tenha viajado de Quioto a Kamakura. A segunda descreve a viagem, de ida e volta a Kamakura, de um recluso que mora nos arredores de Shirakawa, em Quioto. Ele pega a estrada Tōkaidō no dia 4 de abril de 1223 e chega na cidade do governo militar no dia 17. Em estilo que mistura a sintaxe japonesa e chinesa, registra com detalhes a vida dos agricultores que encontrou no caminho, o aspecto das hospedarias, as figuras das meretrizes.

Ben no Naishi Nikki (Diário de Ben no Naishi, +1252) é composto por dois volumes que registram seis anos da vida da narradora-protagonista a serviço da corte do Imperador Go Fukakusa. Tem início no final do reinado do Imperador Go Saga em 1246 e desenvolve-se centrado em poemas. 
Izayoi Nikki (Diário da Lua da Décima Sexta Noite,_1282) foi escrito pela Monja Abutsu. Narra, em duas partes, a viagem de Quioto a Kamakura, fazendo o registro da viagem e o registro da estada na região leste. Com a morte do marido Fujiwara no Tameie, surge o conflito entre Tameuji, filho mais velho do marido, e Tamesuke, filho da protagonista com Tameie, pela posse da casa em Hosokawa na Província de Harima, atual Hyōgo. A autora vai a Kamakura para participar da ação judicial em 1279. Depois da viagem de 14 dias, fixa residência em Tsukigake no Yatsu, um lugar triste, e ela registra os poemas que troca com Tamesuke e Tamemori, que ficaram em Quioto. Na obra, a narradora critica Tameuji, que não se submete ao pai e ao amor filial. A data do último registro gira em torno de 1280 .

Nakatsukasa no Naishi Nikki (Diário de Nakatsukasa no Naishi, „1292), escrito em volume único, tem início no ritual de confissão do Imperador aposentado Fushimi até o retorno da autora para sua terra natal, quando sua doença se agrava. Contém alguns poemas, mas centra-se na narração e é permeado por uma visão obscura da efemeridade budista.

Outros diários são escritos ainda no início do século XI, com uma produção cada vez mais escassa, mas continuada ao longo dos séculos seguintes até uma das últimas datada do início do século XIV, que é Towazugatari de \pm 1306 publicado em português sob o título de As Confissões de Lady Nijō. A autora é a dama do Palácio Nijō que serviu ao Imperador aposentado Go Fukakusa na segunda metade do século XIII. Filha de Koga no Dainagon Masatada, ela começa a freqüentar o palácio aos quatro anos, depois de ter perdido a mãe aos dois anos de idade; desde então, recebe o carinho de Go Fukakusa. A obra narra sua vida na corte, as viagens idolatrando Saigyō com elementos autobiográficos e de diário de viagem, e é composta por cinco partes.

Essa obra caiu no esquecimento depois da Era Muromachi e só voltou a ser reconhecida em 1940, pelo estudioso Yamagishi Tokuhei, mas com o início da guerra não pôde ser pesquisada porque ia contra a autoridade da Família Imperial. Só foi alvo da atenção geral em 1950, após sua publicação com notas explicativas de Yamagishi. 
O período entre a primeira e a terceira parte é conhecido como fase palaciana ou amorosa. A primeira registra a vida da autora dos 14 aos 17 anos, período em que se torna amante de Go Fukakusa e tem relações com Yuki no Akebono. A segunda parte começa em janeiro de 1275 e vai até agosto de 1277, entre os 18 e 20 anos, quando perde o pai; é amante de Ariake no Tsuki; recebe a visita esporádicas de Yuki no Akebono; tem um caso com Konoe Ōdono; e sofre com os insultos dirigidos a sua pessoa. A terceira parte descreve o período de três anos e meio até março de 1285, quando a autora tinha entre 24 e 28 anos e foi banida do palácio imperial. Suas relações com Ariake terminam e o Imperador Aposentado começa a impor restrições.

A quarta parte, que vai de fevereiro de 1289, quando a autora está com 32 anos, até os 37 anos aproximadamente, pois a data torna-se imprecisa e há uma interrupção de quase 10 anos até o início da quinta parte, corresponde à fase conhecida como Vida de Aprimoramento, Peregrinação ou Viagem a diversas regiões, que começa com sua viagem aos países do Leste, e ela torna-se monja. A quinta parte cobre o período dos 45 aos 49 anos da autora e tem início em setembro de 1302, com a viagem aos países do Oeste, e termina em 1306, no terceiro ano de falecimento de Go Fukakusa, com a autora correndo descalça e aos prantos atrás do cortejo fúnebre do ex-Imperador.

Como pode-se ver pelas obras mencionadas acima em seqüência cronológica, a contribuição masculina aparece um pouco depois das obras femininas com Midō Kanpaku Ki de 1021 da autoria de Fujiwara no Michinaga (966-1027) e deixa apenas algumas obras em meados do século XIII, como Gyokuyō; Meigetsuki, Kaidōki, Tōkanki e uma última do início do século XIX, Chichi no Shūen Nikki (Diário dos últimos anos de meu pai, 1801) do poeta Kobayashi Issa.

Nota-se uma diferença ainda no conteúdo dos diários masculinos, que tenderam a descrever assuntos voltados para os eventos, a classe guerreira e a situação política, ao passo que os diários femininos abordaram o dia-a-dia da vida particular de suas narradoras protagonistas como damas da corte e enfocando o lado sentimental.

Pela justificativa que aparece no início da obra: “Geralmente é um homem que escreve aquilo que chamamos de 'Diário', mas agora uma mulher tentará fazê- 
lo", supõe-se que a intenção de Tsurayuki era a de escrever um diário de viagem semelhante aos diários chineses dos governadores em suas idas e vindas das províncias, para as quais eram nomeados; ao fazer que esse diário fosse escrito por uma mulher, o autor possibilitou o abandono do estilo característico de registro para conseguir um meio de expressar livremente os sentimentos pessoais que não the seriam permitidos na posição de oficial do governo no cumprimento do dever.

$\mathrm{O}$ registro dos 55 dias foi ininterrupto mesmo quando consta apenas a data, sem nenhuma informação relevante. $\mathrm{O}$ uso da expressão de suposição no último poema entrega a autoria do mesmo a Tsurayuki, pois a narradora não teria necessidade de empregá-la ao falar sobre seus próprios sentimentos. Essa mudança de foco narrativo revela o disfarce de Tsurayuki na voz narradora feminina. Hagitani Boku (1992) apresenta, entre outros aspectos interessantes, o de que o Diário de Tosa é um tratado poético para os jovens iniciantes do waka.

Observa-se que Izumi Shikibu Nikki é constituído pelo relato de um único episódio em terceira pessoa, o desenrolar do amor de uma dama com o irmão mais novo de seu ex-amor já falecido, até sua união, com uma narrativa em torno dos poemas. Utilizados pela classe aristocrática da época como cartas, inclusive para o cortejo amoroso, os poemas compostos pela dama e pelo Príncipe cumprem uma função de diálogo entre eles. São ambientados num espaço restrito, que é a casa da dama, o palácio e o templo na cidade de Quioto e circunvizinhanças, com outros poucos personagens: o pajem, o acompanhante do Príncipe, a pajem, a ama-de-leite e a esposa do Príncipe. O tempo da narrativa é de dez meses, mas as marcações temporais são diluídas ao longo do texto, que perde a característica de um diário com datas precisas para os fatos, como acontecem com Tosa Nikki e Kagerō Nikki, seus precursores.

$\mathrm{Na}$ obra, não constam informações sobre a vida da protagonista para que se possa associar o episódio do diário à vida real de Izumi Shikibu, nem seu nome é mencionado uma única vez. As pistas para se saber que a dama protagonista é Izumi Shikibu são apenas o título da obra, os dois Príncipes que tiveram um caso amoroso com ela e os poemas da autoria de Izumi, muitos dos quais reunidos em sua Coletânea de Poemas, que ultrapassa o número de 1500 poemas. São encontradas, 
ainda, menções de que o pajem mensageiro das cartas do Príncipe Atsumichi é o mesmo que havia servido ao falecido príncipe Tametaka, irmão mais velho de Atsumichi; quase ao final, uma fala da ama-de-leite que reclama sobre as visitas do príncipe à casa da dama lembra que o falecido irmão também saía com o mesmo acompanhante para ir aos encontros com a dama.

\section{Narrativa Setsuwa}

Paralelamente à literatura feminina representada pela Narrativa, pelo Diário Literário, pelo Ensaio Literário e também pelos poemas, compõe, ainda, o quadro de novas formas a chamada Narrativa Setsuwa, formada por pequenos episódios budistas ou seculares e que tem Nihon Ryōiki (Os Relatos Milagrosos do Japão) cujo título original é Nihon koku genpō zen'aku ryōiki (Registro de fatos insólitos bons e maus e de retribuições no mundo material do Japão) - , da autoria do bonzo Kyōkai, como a primeira do gênero, surgida por volta de 824 .

Konjaku Monogatari shū (A Coletânea de Narrativas Antigas), cujos episódios começam com a famosa frase: "imawa mukashi", literalmente, "agora estamos no passado", ou "antigamente...", tal como os contos de fada, que começam com "era uma vez...", imprime seu teor de relatar fatos ocorridos num tempo passado com homens, animais e entes fantásticos, deste e do outro mundo, como diz Yoshida (1999:66).

No sentido amplo, corresponde a obras sobre histórias mitológicas, lendárias, seculares, narrativas de algum episódio búdico, artístico ou sobre poesia e canção, etiqueta, entre outros temas, transmitidas oralmente e por escrito, às quais aplicaramse técnicas literárias. No sentido restrito, diz respeito às histórias reunidas nas compilações de Setsuwa. Pode-se dizer que a Narrativa retrata o mundo da aristocracia refletindo essencialmente o ideal estético da época, ao passo que a literatura de narrativa tradicional constitui uma literatura que retrata o mundo de maneira mais real, especialmente o do povo em geral, sem deixar de lado o mundo da aristocracia (Yoshida:1991). 
Observa-se que tanto as narrativas Setsuwa de origem budista como as seculares são narrativas populares, "causos" populares da literatura oral e que também serviram de material para as narrativas palacianas. Várias obras foram produzidas desde o século IX até o início do século XIV.

Ujishūi Monogatari, de autor desconhecido, foi escrito provavelmente entre 1213 e 1219. Composto por 15 volumes, reúne 197 narrativas que começam com "Era uma vez..." (Ima wa mukashi ou Mukashi). Dentre elas, mais de 80 sobrepõe-se às existentes no Konjaku Monogatari Shū e outras semelhantes aos do Kojidan, Jikkinshō, Uchigikishū e Gōdanshō. Os volumes não possuem divisões, e as histórias não seguem uma seqüência lógica. Além de setsuwa budistas, contém setsuwa populares que eram transmitidos oralmente na época, como o calombo retirado pelo ogro e a história de retribuição dos pardais. Descreve a vida das pessoas da época e as verdades sobre a natureza humana com histórias cômicas sobre os bonzos e personalidades sagradas, e os vários diálogos presentes na obra apresentam a linguagem oral da época. É escrito em sentenças em japonês chamadas de wabunmyaku, mais simples que a forma empregada em Konjaku.

Kojidan foi escrito por Minamoto no Akikane entre 1212 a 1215. Composto por seis volumes, dividiu cerca de 460 setsuwa reunidos de grande número de livros antigos. A maioria diz respeito a setsuwa sobrenaturais ligadas ao budismo e inclui algumas cômicas. Escrita na chamada wakan konkōbun, uma mistura de japonês e chinês.

Possivelmente escrito por Kamono Chōmei antes de 1215, Hosshinshū reúne capítulos sobre a origem da conversão do bonzo e do desejo do Paraíso Búdico em oito volumes de forte tom budista.

Jikkinshō, da autoria de Rokuhara Jirōzaemon em 1252, como diz o próprio nome, reuniu 282 setsuwa com teor educativo a partir dos livros de história e narrativas, a começar pela Nihon Shoki divididas em 10 volumes para servirem de ensinamentos. Mostra os aspectos positivos de Kiyomori, Shigemori e outras personalidades da Família Taira com ar saudosista.

Escrito por Tachibana no Narisue em 1256, Kokon Chomonjū é composto por 20 volumes. Reúne mais de 700 setsuwa antigos e do época, classificadas em 30 
partes. Copia a estrutura das coletâneas elaboradas por ordem imperial e utiliza textos extraídos de vários documentos. Apresenta marcada adoração pela cultura palaciana abordando o caminho dos poemas e canções e dos instrumentos musicais.

Shasekishū, foi escrito por Mujō (1226-1312), um bonzo zen elevado que estudou várias religiões, viveu entre o povo, ensinando que não se deveria ter restrições religiosas para com nenhuma delas. Foi elaborado em 1283, mas mostra vestígios de acréscimos feitos posteriormente. Composta por 10 volumes, essa coletânea de setsuwa budistas foi escrita com o objetivo de salvar a todos com os ensinamentos budistas. Reúne 125 setsuwa educativos e doutrinários e recebeu influências do caminho da poesia de Saigyō. Nela, encontram-se também setsuwa sobre canções e poemas encadeados. Contém, ainda, assuntos cômicos sem ligação direta com o budismo, e reflete a vida do povo e dos guerreiros da classe inferior.

Yoshino Shūi, obra de 1356, é da autoria de Fujiwara no Yoshifusa. Em dois (ou quatro) volumes, reúne mais de 60 narrativas sobre acontecimentos e histórias de terror ocorridas na corte do sul durante os 23 anos que vão da mudança do Imperador Go Daigo para Yoshino em 1336 até a época do Imperador Go Murakami em 1358. É considerada uma obra intermediária entre Setsuwa e Narrativa Histórica.

As narrativas Setsuwa desaparecem do cenário literário japonês, mas apenas no nome. Na prática, suas histórias são resgatadas de diversas maneiras no período pré-moderno do Japão, na literatura infantil e em alguns escritores do período moderno, como Akutagawa Ryūnosuke, em suas obras Hana (Nariz, 1916) e Dentro do Bosque (Yabu no Naka, 1922), esta última, com tradução em português, e pelo escritor Dazai Osamu com a obra Otogizōshi (Contos de Fadas), escrita durante a Segunda Guerra Mundial.

\section{Narrativa}

Como é possível observar, "narrativa" é um termo utilizado de modo amplo na história literária japonesa, e nesta parte será abordada a Narrativa como gênero que a literatura japonesa classifica em Narrativa Fantástica ou Ficcional (denki monogatari) e Narrativa Centrada em Poemas (uta monogatari). 
As obras mais representativas da primeira são Taketori monogatari (Narrativa do Cortador de Bambu), do final do século VIII a meados do século IX; Utsuho monogatari (Narrativa da Toca da Árvore), de aproximadamente 983; e Ochikubo monogatari (Narrativa do Porão), escrita por volta de 990. Da segunda, Ise Monogatari (Narrativa de Ise), do início do século X; Yamato Monogatari (Narrativa de Yamato), de meados do século X; e Heichū Monogatari (Narrativa dos amores de Taira no Sadabun), da segunda metade do século XI.

Antes do surgimento da Narrativa do Cortador de Bambu, existiram histórias populares simples e antigas sobre conteúdos semelhantes, conhecidas por nomes que variavam entre $O$ velho cortador de Bambu, História da Princesa Kaguya, História do velho cortador de bambu e Princesa Kaguya do cortador de bambu. Considerado pela Narrativa de Genji como ancestral do novo gênero da Narrativa surgido na sociedade Heian, não se sabe ao certo quando essa obra foi escrita, mas há teorias que começam desde 806 e chegam a 956. É composta pelos episódios do nascimento da Princesa Kaguya, do pedido de casamento, das tarefas aos proponentes, da caça, da ascensão da Princesa Kaguya e da poção da imortalidade que virou a fumaça expelida pelo Monte Fuji. Parte de um pressuposto fantástico narrado em terceira pessoa e no modelo "Era uma vez", em que se isenta a veracidade do que é narrado. Apresenta um estilo simples de escrita com grande número de termos budistas e de palavras chinesas e muitas partes que coincidem com a mesma escrita do chinês com leitura japonesa de Kojiki e Nihonshoki. Inicialmente, deve ter sido escrita em chinês.

Utsuho monogatari (Narrativa da Toca da Árvore) também é constituída por uma história fantástica em torno dos mistérios da música narrada em terceira pessoa, composta por pequenos episódios que começam com o modelo semelhante ao "era uma vez". Seus 20 volumes são divididos em duas partes. A primeira, com um tom forte de lenda, focaliza a vida do nobre Kiyohara Toshikage, filho de Shikibu Daisuke e Sadaiben e da Princesa Kihohara Sei, e Nakatada, seu neto. Possuidor de dotes poéticos desde criança, aos 16 anos Toshikage é enviado para estudar na China, enfrenta um naufrágio e pára em terras estranhas, onde vive 23 anos junto a divindades budistas, habitantes celestiais e ermitões, com quem aprende a tocar coto e músicas místicas. De volta ao Japão, casa-se e tem uma filha que, com sua morte, 
mora numa choupana. Depois, casa-se com Fujiwara Kanemasa e tem um filho, Nakatada, muito dedicado à mãe, e que vai morar com ela na toca de um cedro em Kitayama. Nesse local, ela utiliza o talento musical herdado do pai para ensinar o menino a tocar coto e obter favores dos animais da mata mediante a manifestação de fenômenos sobrenaturais. Aos 12 anos, Nakatada é recolhido à casa do pai, juntamente com a mãe, e segue o caminho de ascensão na vida aristocrática. A segunda parte é centrada em descrições sobre a princesa Ate(miya), que tinha muitos pretendentes, entre os quais estava Nakatada, mas ela acaba fugindo para fora da morada das nuvens e transforma-se na Princesa Haru. Ao final, Nakatada e a mãe entregam a música mística transmitida por Toshikage à Princesa Onna Inu e a mãe é designada para um cargo elevado. O fio condutor dessa obra é o mérito da música. Trata-se de uma obra ainda incipiente, do período de transição da lenda para a descrição, e segue a linha do Taketori, centrada nos setsuwa, e a de Ise, centrada nos poemas.

Ochikubo Monogatari (Narrativa do Porão), de autor desconhecido, é constituída por quatro volumes e 100 poemas e cartas muitas vezes completas. Narra a vida da filha de Tadayori Chūnagon que sofre mal-tratos da madrasta e acaba se casando com Shōshō Michiyori, tem dois filhos e vive feliz. O marido consegue a reconciliação entre elas, mas a madrasta continua má até o fim. Mostra os costumes e as relações econômicas e usa personagens nobres. É mais realista que Taketori e Utsuho, mas ainda contém exceções como um idoso de quase 200 anos.

Todos os 29 poemas de Ariwara no Narihira coligidos na Coletânea de Poemas Waka de Outrora e de Hoje estão presentes na Narrativa de Ise, e os poemas foram transformados em narrativas. Dela fazem parte ainda poemas de vários outros poetas, inclusive alguns que parece terem sido retirados do Man'yōshū e transcritos com modificações, e algumas músicas folclóricas. Costuma-se dizer que o protagonista da obra lembra a figura de Narihira, e com isso abre-se a possibilidade de que ele seja um diário poético de natureza autobiográfica.

São 115 capítulos curtos com poemas de conteúdos diversos, a maior parte sobre os sentimentos humanos: o amor pelas mulheres, pelos familiares, pela Natureza e pelo mundo, a consideração para com o Imperador Koretaka e a nostalgia 
da viagem. Uma parte menor é ocupada por poemas de teor espirituoso, engraçados e irônicos e ainda por poemas utilizados em rituais e como decoração de biombos.

Yamato monogatari, Narrativa de Yamato, elaborada entre 951 e 966 por Ariwara Shigeharu ou pelo Imperador Aposentado Kazan, também é composta por capítulos curtos centralizados em poemas que narram episódios relativos aos poemas compostos nas reuniões poéticas da corte. São 173 capítulos divididos em dois volumes, e a partir do 147 tem início o segundo volume, com narrativas curtas, com fortes características Setsuwa.

Heichū monogatari, (Narrativa dos Amores de Taiha no Sadabun_960), de autor desconhecido é constituída por 39 capítulos de Setsuwa poéticos e histórias de amores não correspondidos de Taira no Sadabumi, desenvolvidos em torno de 153 poemas.

Depois de obras que seguem o modelo da Narrativa Fantástica e da Narrativa Centrada em Poemas, em 1001 Murasaki Shikibu começou a escrever a famosa Genji Monogatari (Narrativa de Genji), vista como uma fusão dessas duas modalidades, que as superou e tornou-se insuperável pelas que surgiram posteriormente.

Essa obra que, por volta de 1008, já era muito lida na corte feminina do Imperador Ichijō, é composta por 54 "cadernos" divididos em duas partes. A primeira narra a vida de Hikaru Genji, subdividida em mais duas, que vão do caderno 1 (Kiritsubo) a 33 (Fujinouraba) e do 34 (Wakana I) a 41 (Maboroshi). A segunda parte focaliza a vida de Kaoru, filho de Hikaru com Fujitsubo, sua madrasta e vai do caderno 42 a 54.

Abaixo, apresentamos as três partes de Narrativas de Genji contendo, respectivamente, uma marcação histórica ficcional indicada pelo nome do imperador, a numeração e o título dos cadernos e a idade dos protagonistas entre parênteses, Hikaru Gengi, na primeira e segunda parte, e Kaoru, na terceira parte.

\section{PARTE I}

\section{Imperador Kiritsubo}

1. Kiritsubo (1 12 anos); 2. Hahakigi, 3. Utsusemi, 4.Yūgao (17 anos) ; 5. Wakamurasaki (18 anos); 6. Suetsumuhana, 7. Momijinoga (18 19 anos); 8. Hananoen (20 anos). 


\section{Imperador Suzaku}

9. Aoi no Ue (22 23 anos); 10. Sakaki (23 25 anos); 11. Hanachirusato (25 anos);

12. Suma (26 27 anos); 13. Akashi (27 28 anos).

\section{Imperador Reizei}

14. Miotsukushi; 15. Yomogi U (28 29 anos); 16. Sekiya (29 anos); 17. Eawase, 18. Matsukaze (31 anos); 19. Usugumo (31 32 anos); 20. Asagao (32 anos); 21. Otome (33 35 anos); 22. Tamakazura (34 36 anos); 23. Hatsune, 24. Kochō, 25. Hotaru, 26. Tokonatsu, 27. Kagaribi, 28. Nowaki (36 anos); 29. Miyuki (36 37 anos); 30. Fujibakama (37 anos); 31. Makibashira (37 38 anos); 32. Umegae, 33. Fujinouraba (39 anos).

\section{PARTE II}

\section{Imperador Kinjō}

34. Wakana ue (39 41 anos); 35. Wakana shita; 36. Kashiwagi (48 anos); 37. Yokobue (49anos); 38. Suzumushi, 39. Yūgiri (50 anos); 40. Minori (51 anos); 41. Maboroshi (52 anos); Kumogakure, somente título; o texto não existiu ou não ficou conhecido (morte de Hikaru Genji)

PARTE III - Kaoru

42. Niou no miya (14 20 anos); 43. Kōbai (24 anos); 44.Takekawa (14 23 anos); 45. Hashihime (20 22 anos); 46. Shiigamoto (23 24 anos); 47. Agemaki (24 anos); 48. Sawarabi (25 anos); 49. Yadorigi (24 26 anos); 50. Azumaya (26 anos); 51. Ukibune; 52. Kagerō (27 anos); 53. Tenarai (27 28 anos); 54. Yume no Ukihashi (28 anos).

Murasaki Shikibu descreve a vida com uma atitude realista e com uma fusão habilidosa da natureza e do humano. Foi escrito com um estilo requintado cheio de lirismo poético e do senso de mononoaware sob um planejamento grandioso, que descreve um período de mais de 70 anos, que abrangem quatro reinados imperiais: Kiritsubo, Suzaku, Reizei e Kinjō.

A história começa com a descrição da linda Kiritsubo, quarta Imperatriz e dama preferida do Imperador, que lhe dá Hikaru Genji como herdeiro. Ela adoece com o ódio das outras damas da corte e morre em sua terra natal. O imperador desposa Fujitsubo para esquecer a falecida, e Hikaru encanta-se com a madrasta, que 
se parece muito com sua mãe. Quando ele completa 18 anos, Fujitsubo está grávida e dá à luz Kaoru, que o Imperador acredita ser seu filho. Na época, os filhos eram proibidos de ter relações sexuais com as esposas do pai e por isso a relação de Hikaru com Fujitsubo é incestuosa, mas Hikaru continua a desejá-la e ela, então, decide seguir a vida religiosa ainda jovem. A vida privada do palácio revela suas desavenças humanas, e observa-se que as mulheres enfrentam um conflito interior solucionável apenas pela resignação e pela aceitação do destino.

Saigō Nobutsuna (1972:32-42) afirma que Murasaki Shikibu ficou presa ao destino e todas as personagens femininas da obra, como Kiritsubo, Utsusemi, Aoi no Ue, Murasaki no Ue, Yūgao, Suetsumuhana, Fujitsubo, Akashi no Ue, Tamakazura, Onna Sannomiya, Ujihimegimi e Ukibune, enfrentam o destino e vivem infelizes com a poligamia masculina e os jogos amorosos dela decorrente. Izumi Shikibu foi exceção, mas sofreu de igual modo, deixando-se levar pela condição de mulher.

A autora de Genji Monogatari idealizou sobremaneira o protagonista, que nasceu límpido e cristalino, cresceu de modo ainda mais ofuscante e possuía por si mesmo beleza e talento. Sua carreira também só tendeu a ascender e, mesmo depois de viver refugiado algum tempo em Suma, brilhou ainda mais depois do retorno. Ele não precisou lutar para conseguir o que almejava. Era como se as portas se abrissem porque assim estava determinado. As mulheres sofriam com seu destino, mas encantavam-se e envolviam-se com a vida feliz e exuberante de Hikaru. Sua esposa oficial fez as pazes com ele em seu leito de morte e a infelicidade dela foi recompensada com o futuro de Yūgiri. A rancorosa Rokujō no Miyasundokoro, com quem Hikaru teve uma filha, foi redimida ao se tornar Chūg $\bar{u}$. Em suma, a desavença acaba sendo encoberta pelo mundo harmonioso e belo de Hikaru. Quando ele se tornou primeiro ministro e fez que todas suas mulheres morassem no Rokujōin, esse mundo belo e harmonioso ficou completo.

A infelicidade feminina só encontrou salvação na idealização do protagonista masculino, fazendo que ele fosse dotado de um sentimento piedoso e criasse um mundo de Buda nesta terra. Não há elementos fantásticos nem lendários, como em Taketori. A psicologia humana é discutida com riqueza de detalhes, especialmente das personagens secundárias. As histórias de amor de Hikaru também tomam um 
rumo indefinido, até que chegam à idealização no Rokujōin. $\mathrm{Na}$ segunda parte, porém, esse mundo maravilhoso começa a desmoronar. Onna Sanmiya, esposa do ex-Imperador Suzaku, vai para o Rokujōin como esposa de Hikaru, que não pode tratá-la com menosprezo; quem sofre e adoece é Murasaki no Ue, antes invejada por todas as damas. Ao fim, Hikaru pensa em seguir a carreira religiosa e acaba morrendo.

Assim, a Narrativa desenvolve-se com a Narrativa Ficcional ou Fantástica e a Narrativa baseadas no lirismo dos poemas waka, algumas com características da transmissão oral, como a Narrativa do Cortador de Bambu; outras, como a Narrativa da Toca da Árvore, com elementos fantásticos; e a Narrativa do Porão, de natureza descritiva, que reflete a sociedade da época. A Narrativa passou ainda por um processo de transcrição da realidade, seguindo os moldes do Registro Histórico, da Narrativa Histórica e da Narrativa Militar, e também pela inserção de elementos fantásticos e lendários da Narrativa Setsuwa de tradição popular.

\section{Considerações sobre a literatura feminina}

As mulheres responsáveis pelo florescimento literário desse período eram dotadas de instrução e a maioria delas serviu à corte de Heian, vivendo numa ala denominada Palácio de Trás $(K \bar{o} k y \bar{u})$, que abrigava as esposas do Imperador e outras damas da corte, composta por sete Palácios (Den) e cinco Vivendas (Sha), situada na parte dos fundos do Palácio Imperial (Dairi). Segundo o Dicionário de Pesquisa da História Antiga do Japão, ainda são poucas as pesquisas referentes a esse assunto e restam muitos aspectos a serem elucidados.

O Palácio Imperial de Heian seguiu o modelo do Palácio Heijō da China, mas introduziu aspectos mais práticos e adequados aos costumes e às necessidades japonesas. O sistema político administrativo adotado da China no período anterior também apresenta uma diferença fundamental. Na China, ele serviu para unificar o país em torno do imperador, ao passo que, no Japão, para criar a hegemonia política da família Fujiwara, que utilizou suas filhas para adquirir parentesco com o Imperador e garantir seu poder político, conforme o estudioso Mushanokoji 
(1949:508-17) ao apontar a dificuldade de se manter a estabilidade social e econômica nesse período.

Embora a expressão "literatura feminina palaciana" sugira que a nobreza de Heian fosse a época de ouro das mulheres, elas não possuíam liberdade. Ao contrário, como mostra Saigō (1949:494-507), a vida delas estava presa a preceitos do Confucionismo e do Budismo e era muito desfavorável, como mostram a própria dama da corte Murasaki Shikibu e a autora de Diário de Pirilampo. Na Narrativa de Glória e Poder, a mulher era tratada como um objeto para gerar filhos. O estudioso cita as palavras de Michinaga, o poderoso patriarca do clã Fujiwara, que esteve à frente do sistema político de Tutor e Conselheiro durante mais de vinte anos, a Yorimichi, seu filho, ao tentar convencê-lo de que ter sucessores era uma necessidade e por isso ele deveria desposar a Princesa Daishi, filha do Imperador Sanj, mesmo quando ele já possuía uma esposa que amava (a princesa Taka, filha do Príncipe Guhei). Michinaga também fez que suas quatro filhas, Shōshi, Kenshi, Ishi e Kishi, se tornassem esposas do Imperador para que, com o nascimento do príncipe, ele, como parente sem laços consangüíneos, usufruísse de privilégios políticos.

Lembrando mais uma vez que a nobreza da época seguia o sistema poligâmico para os homens e monogâmico para as mulheres, fica evidente que, por mais que lhes fosse assegurado o conforto material, não haveria de existir a liberdade e a felicidade para elas numa sociedade assim. É ilustrativo o destino trágico de Chūgū Teishi, filha de Michitaka (953-995), a quem Sei Shōnagon servia, quando ela é enganada pela $C h \bar{u} g \bar{u}$ Shōshi (filha mais velha de Michinaga), ou ainda o de Kōi Kiritsubo, personagem do início da Narrativa de Genji, que, por ter perdido o amor do Imperador, é desprezada pelas demais nyōgo e kōi e acaba morrendo. Assim, $C h \bar{u} g \bar{u}$ Teishi não estava ligada ao Imperador Ichijō, seu esposo, mas era sustentada pelo poder de seu pai, Michitaka, e de seu irmão Korechika (974-1010). Com a queda de seus protetores diante de Michinaga, seu tio, Teishi também tem o mesmo destino, e Shōshi, sua prima, assume a posição antes ocupada por ela. Essas disputas parecem ser regra na nobreza Heian, como mostra o Diário de Pirilampo, que nada mais é que um desabafo das mudanças geradas pela poligamia e uma confissão sobre 
a insegurança psicológica da autora, esposa de Kaneie, pai de Michitaka e Michinaga, meio-irmãos de seu filho Michitsuna.

Por isso, é um engano acreditar que a vida palaciana das mulheres da corte de Heian fosse maravilhosa e cheia de esplendor.

A Narrativa de Genji descreve o destino lastimável das mulheres dessa época, e nem Murasaki Shikibu nem a autora do Diário de Sarashina foram servir na corte por vontade própria, idolatrando a vida na corte. Foram enviadas quase à força e se desencantaram com a vida palaciana.

Mushanokōji diz que praticamente todas as artistas literárias da época de Michinaga tinham ligação com o cargo de governador ou vice-governador de províncias. Geralmente eram filhas e esposas desses burocratas, que iam a províncias distantes e que deixavam a família servindo na corte. O dia-a-dia da classe dominante estava no auge do esplendor, e os nobres viviam dias e noites às voltas com as diversões em torno de poemas e cantigas, alheios à calamidade, aos crimes e à fome existente em seu redor. Era nessa vida da corte que essas moças e mulheres da pequena e média nobreza buscavam os recursos para auxiliar sua subsistência, e são exatamente elas que irão sentir os primeiros indícios da queda da alta nobreza. Pois, no período seguinte, há uma mudança significativa. Com a reação da família imperial ao sistema político centralizado nos Tutores e Conselheiros, o Imperador aposentado retoma o governo, e os samurais, que serviam de valiosos instrumentos para os tutores e conselheiros, despertam para o próprio poder. Um fato bastante comentado é o de que, no Diário de Murasaki, a dama recatada e doce que é sua autora critica severamente as mulheres de outros grupos e até as pessoas que serviam à Imperatriz Shōshi, como suas colegas. Mas isso não seria de estranhar se considerarmos que todo esse comedimento e doçura eram uma armadura usada por Murasaki Shikibu para manter a estabilidade de sua vida.

Por isso, Mushanokōji chama a atenção para o fato de que a atmosfera bela e triste, que chega a ser estranha e que paira nas obras por criadas pelas damas da corte, é reflexo da vida das mulheres dessa época, cujos sentimentos aguçados eram estimulados por crescerem numa classe instável e que, apesar de maravilhosa, era uma vida parasitária sempre indefinida. Além disso, a sociedade da alta nobreza 
reunia essas moças e mulheres talentosas como utensílios e adorno de suas filhas, criadas e aperfeiçoadas para competirem com seus talentos. Assim, essas obras raras da literatura japonesa, encabeçadas pela Narrativa de Genji, pelo Diário de Izumi Shikibu e pelo Livro de Cabeceira, não são produtos apenas da força interior dessas mulheres cheias de genialidade que nasceram nesse meio, mas de uma força criada artificialmente em torno delas. Nota-se que é por isso que a literatura feminina não teve a mesma continuidade em épocas subseqüentes.

Saigō (1949b) comenta que o Palácio de Trás era um lugar propício para o desenvolvimento das narrativas e que seu público eram as damas da corte. O Livro de Cabeceira foi escrito segundo a vontade de Chūg $\bar{u}$ Teishi, como consta no final da obra, e diz-se que a Narrativa de Genji foi confeccionada porque a Princesa Senshi, filha do Imperador Murakami, queria outros textos para leitura, porque já estava farta de ler a Narrativa da Toca da Árvore e a Narrativa do Cortador de Bambu.

Podemos, assim, dizer que grande parte da riqueza literária desse período encontra-se na literatura feminina e que ela está intimamente ligada ao sistema político em torno do Tutor e do Conselheiro, que garantiram a manutenção do poder do Clã Fujiwara. As imperatrizes geravam os futuros sucessores ao trono, que seriam regidos e aconselhados pelo avô materno.

\section{As novidades até o final do século XIX}

Desse modo, o Japão produziu seu corpus literário com gêneros e nomes próprios a partir das contribuições recebidas da cultura chinesa, adotando seu sistema político-administrativo, implantando o Budismo e o Confucionismo nas esferas governamentais e empregando os ideogramas chineses para os documentos burocráticos e para a composição de poemas que seguiam os modelos da China. Em suas bases, contudo, preservou um pensamento eminentemente japonês fundamentado na hierarquia que descende da divindade criadora do céu e da terra e preservou as crenças e as formas literárias primitivas das cantigas e lendas, dando vida e forma à língua japonesa, como se propõe a mostrar o Kojiki. Após essa fase de introdução e assimilação, manteve uma produção baseada nas primeiras obras e criou 
gêneros novos como a Narrativa, o Diário e o Ensaio, sustentados pelo desenvolvimento da escrita em fonogramas e da adaptação dos ideogramas ao vernáculo.

Durante a Idade Média, o país mergulhou em sucessivas guerras civis, e a literatura feminina, antes muito próspera, começou a desaparecer juntamente com o regime político dos Tutores e Conselheiros do clã Fujiwara.

Nesse período, houve uma continuidade dos mesmos "gêneros", como já foi visto nos respectivos itens sobre o Ensaio, o Diário e a Narrativa Setsuwa. Após a insuperável Narrativa de Genji, vista como resultado da Narrativa Ficcional e da Narrativa Centrada em Poemas, algumas obras que seguiram sua linhagem continuaram a ser produzidas, como Yoru no Nezame, Hamamatsu Chünagon Monogatari, Sagoromo Monogatari, Torikaebaya Monogataria e Tsutsumi Chūnagon Monogatari, até o final do século XII, quando o Japão já começava a ser dominado politicamente pela classe guerreira.

Presume-se que Yoru no Nezame (O Despertar na Noite, \pm 1059$)$ foi escrito pela filha de Sugawara no Takasue (autora do Diário de Sarashina) que descreve o romance de Gon Chūnagon com Nezame no Ue, que significa "despertar", utilizado no título da obra, retratando a psicologia das personagens com riqueza de variações na estruturação. Apresenta forte inclinação para a Narrativa de Genji.

Hamamatsu Chūnagon monogatari (Narrativa de Hamamatsu Chūnagon, $\pm 1055)$, da suposta autoria da filha de Sugawara no Takasue, é uma narrativa fantástica, em cinco volumes, sobre o lindo amor de Hamamatsu Chūnagon com a filha de seu padrasto e a tristeza de seu amor com a Princesa Ama no Kimi, que mora em Yoshino, no Japão, e é mãe da Imperatriz de Tang, para a qual fez juras de amor quando foi à China, atendendo a pedido feito pelo pai em um sonho.

Provavelmente da autoria de Koshikibu, mas com dois ou mais autores, Tsutsumi Chūnagon Monogatari (Narrativa de Tsutsumi Chūnagon) é composto por dez volumes de narrativas curtas. O primeiro volume é de 1055, final de Heian, com conteúdos humorísticos escritos em $3^{\mathrm{a}}$ pessoa, mas desconhece-se a época em que foi reunida na forma dessa coletânea com poemas. 
Escrito em meados do século XI, e de autor desconhecido (provavelmente Daini no San'mi, irmã de Murasaki Shikibu, ou filha de Minamoto no Yorikuni, que serviu ao Imperador Aposentado Rokujō Sai), Sagoromo Monogatari (Narrativa de Sagoromo), Narra em quatro volumes a história do protagonista Sagoromo, que nutre uma paixão não correspondida por Genji no Miya, sua prima. Mesmo depois de ter relações com Asukai no Kimi, Ippon no Miya e outras mulheres, o príncipe ainda não esqueceu seu antigo amor. Ao tornar-se Imperador, conhece então Ariake no Kimi, muito parecida com a prima, e acaba se casando com ela.

Torikaebaya Monogatari (Narrativa de um Desejo de Transformismo, 11681180), também de autor desconhecido, narra a história de Gon Dainagon que tem um irmão e uma irmã de mães diferentes. $\mathrm{O}$ irmão é afeminado, e a irmã, masculina, e por isso o nome da obra, que deseja que os sexos sejam trocados. É uma obra com características fantásticas e forte tendência à decadência que imita a Narrativa de Genji.

No século XIII, surge um novo grupo de obras, conhecido por Narrativa Imitativa (Giko monogatari), que copiava o modelo das narrativas palacianas e era produzido por nobres saudosistas da época de glória de sua classe. Sumiyoshi Monogatari (Narrativa de Sumiyoshi, \pm 1221 ) é de autoria desconhecida e narra os maus-tratos de uma madrasta para com a enteada, nos moldes da Narrativa do Porão. Seu nome é mencionado na Narrativa de Genji e no Livro de Cabeceira, e presume-se que seja reelaboração de uma narrativa de um período antigo. Matsura no miya monogatari, 1193?, escrito provavelmente por Fujiwara no Sadaie (Teika) é composto por três volumes. O cenário é transportado para a China e a época, para o período da Capital em Fujiwara, anterior ao período Nara. Imita a Narrativa da Toca da Árvore, tanto na estrutura quanto no estilo de escrita. É uma narrativa fantástica, com ares estrangeiros, que lembram a Narrativa de Hamamatsu Chūnagon. Há ainda outras como Koke no Koromo (Veste de Musgos, 1271); Iwashimizu Monogatari (Narrativa Iwashimizu , 1271?); Ama no Karumo (Veste Delicada dos Céus, ?); Waga Mi ni Tadoru Himegimi, (A Princesa de meus Sonhos, 1271?). 
Esse grupo, porém, logo desapareceu, ofuscado pelo brilho da Narrativa Militar e especialmente pela Narrativa Setsuwa, que alcançaram sua época áurea nesse período.

Entre meados do século XV e o século XVI, o Japão recebeu influências portuguesas por meio dos padres jesuítas, que alcançam êxito suficiente para fazer que as autoridades japonesas proibissem o Cristianismo e banissem os jesuítas do país, sem contudo deixar influências expressivas na literatura, como ocorreu nas artes plásticas. Desse contato com os portugueses restou a obra Isoho Monogatari (Narrativa de Esopo), também conhecida como Fábulas de Esopo, uma edição cristã com informações sobre o autor e as fábulas de sua autoria. Ela foi publicada pelo Colégio Amakusa da Companhia de Jesus em 1593 e, posteriormente, elaborada como kanazōshi no século XVII.

Entre os séculos XV e XVI, surge outra forma em prosa, conhecida por monogatarizōshi, nome formado por "narrativa" (monogatari) e "rascunho, escritos" (zōshi). Trata-se de uma narrativa maravilhosa com teor educativo e moral, destinada a um público feminino e infantil, mas que também retratava a sociedade e os homens da época. Inicialmente, fizeram parte desse gênero 23 obras publicadas, sob o nome de Otogizōshi "escritos maravilhosos" — ou Coletânea de Narrativas de Entretenimento, conforme usa Yoshida (1999:69) —, pelo impressor e editor Shibukawa Seiemon, de Osaka, das quais fazem parte as obras Issunbōshi (O Menino de Três Centímetros), Hachi Katsugi (A Carregadora de Vaso), Shuten Dōji (Ladrões de Mulheres e Crianças) e Monokusatarō (Monokusatarō), todas de autores desconhecidos e sem data certa de elaboração. Posteriormente, o nome otogizōshi assumiu um sentido mais amplo de conto maravilhoso.

No século XVII, o Japão fechou-se para o mundo, mas continuou o contato com a China por meio do comércio e com os documentos holandeses, voltados principalmente para a medicina. Diversas medidas foram tomadas para consolidar o isolamento do Japão, mas com maior rigor a partir das leis de 1635, que proibiu a saída dos japoneses, e de 1639, que impediu a entrada dos portugueses. Nesse período, dois tipos de obras em prosa seguiram na esteira do "conto maravilhoso": o conto com ilustração, conhecido como kusazōshi, e o conto escrito em kana, 
chamado de kanazōshi. Ambos foram gerados nos centros cultural e econômico de Quioto e Osaka, que floresceram na famosa Era Genroku (1688-1703).

O primeiro continuou como leitura destinada ao público feminino e infantil, e recebeu capas de cores vermelha, preta e azul clara esverdeada, que the deram os nomes de Livro Vermelho (akabon) - geralmente com histórias infantis, como Batalha entre o Macado e o Caranguejo (Saru-kani gassen), O Pardal de Língua Cortada (Shitakiri suzume) —, entre 1704 e 1736; Livro Preto (kurobon), entre 1748 e 1764; e, em seguida, Livro Azul (aobon), alterações essas decorrentes da política de economizar nos custos. A partir de meados do século XVIII, nas Eras chamadas de An'ei (1772-1780) e Tenmei (1781-1788), estes se desenvolveram para o Livro de Capa Amarela (kibyōshi) - cuja obra mais representativa é Kinkin Sensei Eiga no Uume (O sonho de Prosperidade do Professor Kinkin), da autoria de Koikawa Harumachi (1744-1789), publicado em 1775 -, que com expressões chistosas e cômicas fizeram sucesso entre os adultos, e nas Eras Bunka (1804-1817) e Bunsei (1818-1829) passaram a ser designados como Volume Reunido (gōkan), ao assumirem um conteúdo mais complexo e extenso, com vários tomos que necessitavam ser compostos em um único livro. Entre 1829 e 1842, surgiu a paródia de Genji Monogatari, intitulada Nise Murasai Inaka Genji (A Falsa Murasaki e o Genji Provinciano), de Ryūtei Tanehiko (1783-1842), obra-prima desse gênero, mas que não foi concluída em razão da encadernação de luxo, que infringia a lei da Reforma de Kansei de 1787 a 1793, realizada por Matsudaira Sadanobu, que ordenava, entre outras coisas, economizar, fazer doações, criar um fundo de emergência para calamidades e fome, devolver para suas terras as pessoas naturais do interior, que estavam nos grandes centros. Além disso, proibia todo tipo de Confucionismo que não fosse o de Chu-tzu.

Kanazōshi, o segundo, durou cerca de 80 anos, produzindo obras como Seisuishō (Episódios Cômicos), de 1628, de autoria desconhecida, com cerca de mil episódios humorísticos; Nise Monogatari (Narrativa de Nise), de autoria desconhecida e escrita entre 1624 e 1628, é uma recriação lingüística da Narrativa de Ise, que já começa no título, com a proximidade sonora de Ise, nome da província, e nise, que significa "falso"; Otogibōko (Histórias da Serva), de Asai Ryōi ( $₫ 1612-$ 
1691), é uma coletânea de contos de terror baseados em histórias chinesas publicada em 1666.

Kanazōshi dá lugar ao ukiyozshi, livro com predominância de textos descritivos com características instrutivas e moralistas, que receberam classificações por seu conteúdo. Há, ainda, o romântico e sensual (kōshoku mono), cujas obras mais representativas são Kōshoku Ichidai Otoko (Os Amores de uma Vida Inteira de um Homem), o primeiro do gênero, publicado em 1682; e Kōshoku Ichidai Onna (Os Amores de Cinco Mulheres), de 1686; o misterioso e lendário (zatsuwa mono), com Saikoku Shokoku Banashi (Histórias de Diversas Regiões do Oeste), de 1685; o que aborda a vida e a estética dos samurais (buke mono), com Registros Transmitidos sobre o Caminho do Samurai (Budōdenraiki), de 1686; e o que narra os sucessos e a vida dos citadinos (chōnin mono), como Nihon Eitaikura (Riquezas Acumuladas pelos Japoneses), de 1688.

Ihara Saikaku (1642-1693) foi o grande autor dessa vasta produção, posteriormente substituída pela obras da editora Hachimonji, representada principalmente pela obra Keisei Iro Shamisen (Histórias do Shamisen Erótico), escrita em 1701 por Ejima Saseki (1666-1735). Desta última desenvolveu-se o livro de leitura yomihon, centralizado em textos ricos e em elementos fantásticos, em leis budistas de causa e efeito e em preceitos morais. Em Edo, ele é representado por Ueda Akinari (1734-1809), autor de obras como Contos da Chuva e da Lua (Ugetsu Monogatari) — com tradução em português —, de 1776, e por Takizawa Bakin (1767-1848), que, entre outras obras, escreveu Chinsetsu Yumiharizuki (Histórias da Lua Crescente), em 1807, e Nansō Satomi Hakken Den (Os Oito Bravos Cães do Clã Satomi), entre 1814 e 1842, esta última inspirada na obra chinesa Suikoden (Histórias à Margem d'Água) da dinastia Ming. Na região de Quioto e Osaka, a primeira obra desse tipo é Hanabusa Sōshi (Escritos de Hanabusa), publicada em 1749 por Tsuga Teishō (1718-?).

Além de dar origem aos Livros de Leitura, o kanazōshi desenvolveu uma linhagem de prosa voltada para a sensualidade e o erotismo, com foco no conhecimento apurado sobre o mundo das mulheres e dos clientes das zonas dos prazeres, representada pelos Livros de Sensualidade (sharebon). Eles acabaram 
desaparecendo depois que Santō Kyōden (1761-1816) foi condenado por atentado ao pudor, mas deixou obras como Tsūgen Sōmagaki (Histórias sobre a Casa Sōmagaki), de 1787. Dos Livros de Sensualidade surgiram duas linhas distintas, que são os Livros de Sentimentos (ninjōbon) e os Livros Cômicos (kokkeibon). O primeiro foi apreciado pelo público feminino por descrever os sentimentos e os sentidos, abordando o amor na vida do povo e os conflitos interiores dos seres humanos, mas acabou desaparecendo por causa da repressão iniciada em 1841 com a Reforma de Tenpō (1841-1843), realizada por Mizuno Tadakuni, que incentivou a dedicação aos estudos, a economia e o cumprimento dos costumes, dissolveu os atacadistas e ordenou a redução dos preços.

Tamenaga Shunsui (1790-1843), apesar de ter sofrido sanções por infringir a moral e os bons costumes, deixou obras como Shunshoku Umegoyomi (Paisagem de Primavera, Beleza da Ameixeira), escrita em 1832. O Livro Cômico foi desenvolvido de modo paralelo ao primeiro, com descrições sobre os aspectos engraçados e sensuais no cotidiano do povo. Seus principais representantes nas regiões de Quioto e Osaka foram Jippensha Ikku (1765-1831), autor de Tōkaidōchū Hizakurige (Viagem a Pé pela Via Tōkai), que teve a primeira parte publicada em 1802 e a continuação em 1822, e Shikitei Sanba (1776-1822), que escreveu Ukiyoburo (Banho Público do Mundo Flutuante), em 1809. Em Edo, havia Hiraga Gen'nai (1728-1779), que produziu a obra Fūryū Shidōkenden (Histórias Inusitadas de Shidōken) em 1763, satirizando os costumes do povo da capital militar.

Assim, essas formas literárias, em grande parte voltadas para a diversão e para a comicidade, geraram a literatura de entretenimento na prosa do final do século XIX, que corresponde ao início do período Meiji, quando termina o isolamento japonês.

\section{Considerações sobre as formas em prosa da Idade Pré-Moderna}

Apesar da grande produção de obras do gênero Setsuwa, na Idade Média japonesa ele acabou desaparecendo. O Ensaio e o Diário Literário também perderam 
a força e apenas o Registro de Viagem, iniciado como ramificação do Diário Literário, continuou a ser produzido ligado principalmente aos poemas haikai.

Na Idade Pré-Moderna, houve um crescimento admirável da erudição "chinesa" e também uma diversificação nos nomes recebidos pela obras em prosa desse período, que estiveram mais próximas das camadas populares.

$\mathrm{Na}$ classificação do estudioso Nakamura Yukihiko (1968:415-32), a prosa pré-moderna pertenceria ao grupo comum (zokugun), em contraste com o grupo refinado (gagun), e pela tradição que vinha desde a Idade Média este último era reconhecido como caminho elevado e artístico $(d \bar{o})$. O grupo comum surgiu para suprir as necessidades literárias que o grupo refinado não satisfazia, mas era considerado inferior por apresentar o lado utilitário que era o da lição, da divulgação e da diversão.

Nakamura segue a linha das diferenças estabelecida entre o sagrado e o profano, o nobre e o plebeu, e assemelha-se à classificação em superior e inferior, que vemos em Frye: o herói é superior em espécie aos outros, no romance é superior em grau, nos modos "altamente miméticos" da tragédia e da epopéia, superior aos outros em grau, mas não ao ambiente, nos modos "reduzidamente miméticos" da comédia e do realismo igualava-se a todos nós, e na sátira e ironia era inferior. $\mathrm{O}$ estudioso classificou a arte literária do período pré-moderno em dois grupos: o refinado (gagun) e o comum (zokugun). O primeiro é constituído pelos poemas japoneses (waka), textos japoneses (wabun), poemas encadeados (renga), poemas chineses (kanshi), textos chineses (kanbun), formas literárias tradicionais japonesa e chinesa (wakan); o segundo, pelo poema satírico (haikai), o poema "ensandecido" $(k y \bar{o} k a)$, os escritos que foram utilizados para o teatro de bonecos (jōruri), o teatro cabúqui e a prosa pré-moderna (kinsei shōsetsu).

De modo semelhante, o estudioso Hinotani Hirohiko (1994:6) menciona essa divisão das artes literárias ao expor que Takizawa Bakin, um dos grandes escritores de sucesso entre as camadas populares, confessou que escrevia para conseguir comprar os livros confucionistas e as coletâneas de poemas chineses considerados a literatura por excelência, pois a sociedade da época compunha poemas em chinês e, para ela, o sentido primeiro da Literatura era interpretá-los e apreciá-los. 
Como resultado das modificações ocorridas pela influência mútua desses dois grupos, do incentivo do governo para educar o povo por meio da instrução e da leitura, do avanço das técnicas de impressão, do esforço dos editores, livreiros e escritores e provavelmente do interesse dos leitores, a literatura, no entanto, alcança um desenvolvimento surpreendente nas camadas populares.

Tanto Nakamura quanto Hinotani apontam o Confucionismo como elemento primordial que influenciou a literatura. Nakamura diz que a ciência de Chu-tzu penetrou na sociedade depois de ter sido adotada como princípio norteador da política cultural da fase inicial do governo Tokugawa, e as artes literárias serviram para transmitir o caminho e formar uma sociedade moral baseada no incentivo ao bem e na repressão ao mal, tanto na arte refinada quanto na secular. Ele diz, ainda, que os escolásticos de Chu-tzu chegaram a condenar clássicos como as Genj Monogatarii e Ise Monogatari como livros que ensinavam a lascívia. Hinotani mostra que a literatura comum colocada abaixo da literatura chinesa continuava a ser publicada em larga escala e era muito lida, e cita como exemplo as obras de autores, como Saikaku, que continham um fundo moral proveniente do Confucionismo expresso nos preceitos morais no final ou no meio da obra.

Segundo Hinotani (1994:6), o florescimento cultural da Idade Pré-Moderna foi causado por quase três séculos de paz e felicidade única em toda a história do Japão.

A preocupação com a moral continuou a existir na literatura, mas a tendência para a diversão aumentou. Nakamura aponta que a Narrativa Militar abandonou os registros épicos para se transformar em "causo" de samurais, como a obra Taikōki (Registro de Toyotomi Hideyoshi), de 1625, que incluía críticas do ponto de vista da ciência militar, da política e da moral; o Ensaio literário, os textos budistas e também os textos com bases confucionistas e xintoístas transformaram-se em lições adaptadas à nova sociedade; as coletâneas de Narrativa Setsuwa da Idade Média são publicadas juntamente com as traduções desse mesmo gênero chinês; e o Registro de Viagem transformou-se em guia de lugares pitorescos e famosos. Até as histórias de natureza maravilhosa e de amor sofreram transformações e deram origem à literatura jocosa, que retratava a sociedade da época com as paródias dos clássicos, 
denominadas Narrativa Imitativa. Em seguida, novos termos surgem para designar as obras em prosa que se desenvolvem a partir do kanazōshi, surgido entre as eras Kan'ei (1625-1643) e Kanbun (1661-1672).

Nakamura Yukihiko menciona outra mudança significativa que influenciou o pensamento e a literatura da época: a afirmação da realidade no lugar da negação do mundo terreno pregado pela religião Jōdo, predominante na Idade Média. Os avanços da nova sociedade em que reinava a paz foram retratados e divulgados, e as personagens tornaram-se independentes das divindades que regiam seus destinos. Elas passaram a ser modelos de resultados obtidos pelo esforço individual e, assim, a dar esperanças ao povo, e a linguagem oral também ganhou espaço na literatura com seu uso na composição do haikai, dos kanazōshi e do teatro.

Na Era Genroku (1688-1703) surgiu um ar humanístico com os pensadores confucionistas Itō Jinsai (1627-1705) e seu filho Tōgai (1670-1736), que defenderam a literatura como expressão do sentimento humano e puseram fim à teoria do incentivo ao bem e da repressão ao mal. O estudioso do vernáculo e poeta Keichū (1640-1701) também valorizou o sentimento humano em suas teorias sobre o poema waka e as narrativas, e sob a crença de que o comum e o secular transmitiam melhor os sentimentos viu-se a publicação de coletânea de poemas dos nobres inferiores, conhecidos por jige. Nakamura diz que os escritores representativos das artes seculares, como Ihara Saikaku, Matsuo Bashō e o roteirista de teatro de bonecos e de cabúqui Chikamatsu Monzaemon (1653-1724), compartilhavam de idéias semelhantes à de Jinsai e que a narrativa do mundo flutuante (ukiyozōshi) de Saikaku e o novo haikai de Bashō nasceram das transgressões das antigas leis e regras e do interesse em retratar os sentimentos humanos, fossem eles eróticos, morais ou voltados para interesses financeiros.

Até o final da Idade Pré-Moderna o povo era totalmente desprovido de consciência sobre os assuntos do país, e Hirotani interpreta que isso poderia ser considerado tanto uma falha do governo militar como algo digno de admiração, tamanha era a tranqüilidade da vida do povo japonês. Como comprovação, cita o exemplo dos agricultores da época, que não demonstraram nenhum interesse na Guerra Boshin, de 1868, entre as tropas do governo da restauração e as tropas do 
antigo regime militar. Diz ele que o povo em geral ficou alheio à situação do final do governo militar e deleitava-se com o mundo fantasioso da literatura e dos teatros, e menciona que foi por esse motivo que a obra Shiranui monogatari, de Ryūkatei Tanekazu, que começou a ser publicada em 1849, continuou com grande popularidade até 1886, quase vinte anos após a Renovação Meiji.

Hirotani vê o ano de 1871 como marco que separa a Idade Pré-Moderna da Moderna. Em 23 de março desse ano, Narushima Ryūhoku, escritor neoconfucionista e ex-ministro do antigo governo militar, concluiu o segundo volume de Nova História da Ponte Ryū (Ryūkyō Shinshi ou Yanagibashi Shinshi), mas sua publicação atrasou e esse volume acabou como documento inútil, que mostrava a situação da zona dos prazeres, quando, na realidade, criticava por meio da fala de uma artista da zona os samurais das classes inferiores que ocupavam cargos administrativos do governo militar. Para ele, Panela Agura de Robun, publicada em abril, marcou o fim do kusazōshi da cultura Edo.

Desse modo, foram apresentadas as formas literárias japonesas centradas na prosa. A partir do momento em que elas ganharam a forma escrita sob influência da cultura chinesa importada, ainda nos primeiros séculos da Era Cristã, acompanhou-se o surgimento de novos gêneros com nomenclatura própria, quando cessam os intensos intercâmbios realizados com a China no final do século IX e o Japão cria um sistema peculiar de governo, que gera uma Literatura Feminina muito próspera nesse período.

Em seguida, viu-se uma fase transitória sem novidades significativas em função das guerras internas japonesas até o fim do século XVI, e em seu final o desenvolvimento de novas formas literárias voltadas para o entretenimento da camada popular, que foi conquistando seu espaço nos grandes centros urbanos. Nessa época, a literatura e as artes deixam de ser privilégio da classe alta. No entanto, ainda prevalece a divisão entre o refinado e o comum, seja na prosa, na poesia ou nas artes cênicas, estas últimas estruturadas nesse período. No entanto, as chamadas artes de entretenimento consideradas do grupo comum alcançam um crescimento notório. Os literatos e estudiosos continuaram a valorizar a forma poética tradicional japonesa e os poemas e textos chineses pertencentes à esfera refinada, mas alguns se dedicam à 
criação de obras da esfera comum, que alcança uma produção variada e grandiosa com o incentivo do governo, o avanço das técnicas de impressão e o interesse de editores e leitores.

A partir de meados do século XIX, o Japão entrou numa nova fase histórica ao sair do isolamento e, assim, a literatura japonesa passou novamente a receber influência estrangeira, dessa vez dos países ocidentais.

\section{As influências ocidentais}

O Japão, após um período de isolamento de quase trezentos anos, passou por um período de intensa transformação, com as novidades trazidas do Ocidente. Objetivado um rápido crescimento com a modernização, contratou especialistas estrangeiros para trabalharem no país e também enviou estudantes e pesquisadores das mais diversas áreas à Europa e aos Estados Unidos.

O esforço em prol da "iluminação" dos japoneses resultou em trabalhos como a tradução de Self Help, de Samuel Smiles, em 1871, publicada com o título de Saikoku Risshihen (Motivação dos Países Ocidentais) pelo ministro do governo militar Nakamura Masanao (1832-1891), logo após sua viagem à Inglaterra, e Gakumon no Susume (Incentivo ao Conhecimento), escrito em 1872 por Fukuzawa Yukichi (1835-1901). Considerada a bíblia da nova Era, essa obra defendia a igualdade natural entre os homens e a visão utilitarista do conhecimento, mostrando a igualdade entre nobres e plebeus, ricos e pobres, e incentivando as pessoas a se dedicarem aos estudos e acumularem grandes conhecimentos para alcançarem a dignidade e a riqueza.

Inicialmente, procurou-se divulgar o conhecimento ocidental por meio de algo que recebeu o nome de Literatura Traduzida e Romance Político. Muitas obras foram publicadas em japonês na forma de adaptações ou sem que tivessem sido traduzidas diretamente do original. Em razão do interesse pelos movimentos de liberdade democrática, na época defendidos pelos países ocidentais, grande número de obras focalizava os políticos ocidentais ou os assuntos políticos, como Utopia, de Thomas Moore. O crítico e historiógrafo literário Nakamura Mitsuo cita $A s$ 
Aventuras de Telêmaco, de Fenelon, traduzida em 1879, como exemplo precoce de apresentação de um clássico francês. ${ }^{1}$. Entre os interessados pelos estudos ocidentais, contudo, houve também quem procurasse divulgar o lado sentimental dos estrangeiros, e as obras de Lord Litton foram das que mais ganharam popularidade nesse período. Shakespeare também teve suas obras traduzidas e foi interpretado no estilo dos livros da literatura do período pré-moderno japonês, que retratam os sentimentos humanos. Júlio Verne foi alvo de grande interesse pelas aventuras e inovações tecnológicas apresentadas.

Nas últimas décadas do século XIX, entraram em cena obras produzidas pelos próprios japoneses, com características de romances que apresentavam ideais e visões políticas, mas que tiveram vida curta em função das pressões governamentais. Entre elas, estão Keikoku Bidan (Belas Histórias de Liderança Nacional), escrita em 1883 por Yano Ryūkei (1850-1931), com a brilhante atuação de Epaminondas e Pelópidas na política da cidade de Tebas; Kajin no Kigū (Encontro Inesperado de uma Beldade), de 1885, da autoria de Tōkai Sanshi (1852-1922), que mostra a ameaça a que o Japão estava exposto, com base na história de sete outros países e nas dificuldades e sucessos de um jovem político, contados por Suehiro Tetchō (184996) em Setchūbai (Flor de Ameixeira na Neve), de 1886.

Essas obras substituíram a literatura de entretenimento iniciada no período pré-moderno, antes da abertura do Japão, e que na primeira década de Meiji (18681878) ainda florescia pela mão de autores como Kanagaki Robun (1829-1894) e Narushima Ryūhoku (1837-1884), que fizeram muito sucesso com suas obras que ironizavam e satirizavam a situação japonesa diante da proposta de modernização do país, seguindo os moldes ocidentais. Nessa linha podem ser citadas as obras Seiyōdōchū Hizakurige (Viagem à Pé pela Via Ocidental), de 1870, e Agura Nabe (Panela Agura) de 1871, ambos de Robun, e Ryūkyō Shinshi (Nova História da Ponte Ryū), escrita por Ryūhoku em 1874.

Após essa fase inicial de uma literatura utilitarista, Tsubouchi Shōyō (18591935), com sua instrução de literatura inglesa, publicou o livro de crítica Shōsetsu Shinzui (Essência do Romance, 1885), e indicou o caminho da objetividade e da

\footnotetext{
${ }^{1}$ Nihon no kindai shōsetsu. (Romance Moderno Japonês ,1954), p. 24.
} 
análise psicológica para a literatura moderna em detrimento do método utilitarista, como lição de moral ou propaganda política de até então. Escritor, dramaturgo, crítico e tradutor, fundou a Revista Waseda Bungaku em 1891, publicou alguns romances como Tōsei Shosei Katagi (Natureza de um Estudante, 1885), escreveu dramas como Kiri Hitoha (Uma Folha de Paulonia, 1894) e em 1928, traduziu as obras completas de Shakespeare

Futabatei Shimei (1864-1909) concretiza sua teoria literária na obra Ukigumo (Nuvens Flutuantes, 1887), utilizando a linguagem oral para descrever a interioridade dos intelectuais que sofriam entre o novo e o antigo pensamento. Shimei contribuiu ainda com suas traduções de Turgueniev, Gogól, Gorky, Andreev e Garsin, consideradas trabalhos cuidadosos que foram alvo de elogio entre tantos que sofreram modificações inadequadas.

Shōsetsu Shinzui foi uma obra fundamental para a valorização da figura do escritor na sociedade japonesa. Na época, a literatura de entretenimento do período anterior era desconsiderada a ponto de os escritores serem tratados como párias, mas o romance repentinamente foi elevado à categoria de arte, como importante elemento que contribui para a cultura, e a profissão de romancista, reconhecida como carreira digna. Isso abriu uma nova perspectiva para os jovens japoneses, que anteriormente só vislumbravam um futuro promissor na carreira política.

O historiógrafo literário Takagi Ichinosuke observa que a prosa japonesa foi influenciada pelos novos pensamentos ocidentais tanto na esfera religiosa e filosófica quanto política, e afirma que a valorização do indivíduo, o aumento do espírito humanitário e a igualdade dos seres humanos perante Deus foram resultado do Cristianismo. Para Takagi, Fukuzawa Yukichi divulgou o existencialismo e o positivismo e incentivou os japoneses a buscarem o conhecimento por meio de obras como Seiyō Jijō (Informações sobre o Ocidente, 1866) e das já mencionadas Gakumon no Susume e Shōsetsu Shinzui, esta última conduzindo a prosa japonesa a descrever os sentimentos humanos e os costumes da sociedade sem muito embasamento teórico.

Com Tōsei Shosei Katagi (Natureza de um Estudante, 1885), Fukuzawa Yukichi procurou mostrar na prática o que era defendido teoricamente em Shōsetsu 
Shinzui. Apesar de refletir os pontos fracos dessa obra, enfocou a atitude de um estudante perante as novas contingências de vida, mas os termos empregados e o estilo de escrita ainda se mostram obsoletos. Takagi, comentando Ukigumo, de Shimei, diz que essa obra aplica o que o próprio Shimei defende em Shōsetsu Sōron (Teoria Geral do Romance, 1886) e por isso significa um avanço em relação a Tōsei Shosei Katagi. Em sua visão, a personagem principal procura viver fiel a seus princípios, mas se vê num beco sem saída diante das pressões dos poderes administrativos, feudais e utilitaristas, e o autor, por sua vez, consegue ir além da descrição do sentimentalismo humano e da situação social, na medida em que apresenta concretamente os problemas que ele próprio enfrentou. Essa obra ficou inacabada, mas na visão do historiógrafo marcou o início de uma literatura com características modernas.

Quase simultânea à apresentação do realismo descritivo iniciado por Shōyōe Shimei surgiu uma reação à onda de ocidentalização com o pensamento nacionalista, e os literatos voltaram-se para os clássicos japoneses, especialmente com a formação dos corporações literárias.

A primeira e maior de todas foi a Ken'yūsha, criada em 1885 sob a liderança de Ozaki Kōyō (1867-1903), que se voltou para os romances de costumes de estilo requintado, e Kōda Rohan (1867-1947), que utilizou as características da língua japonesa mescladas à chinesa, concomitantemente ao toque popular com o erudito. Em torno deles, reuniram-se vários escritores com uma relação de amizade, de mestre e discípulo, ou ainda de apadrinhamento ou de negociação, com o intuito de criar "discípulos de futuro". Seus integrantes poderiam não defender os mesmos princípios literários nem os mesmos ideais, mas formavam uma mesma organização literária.As obras conhecidas pelo nome de romances trágicos ou graves (Hisan ou Shinkoku Shōsetsu) e romance de idéias (Kan’nen Shōsetsu) produzidas nessa época são da autoria dos escritores da Kenyūsha. Kurotokage (Lagarto Negro, 1895), de Hirotsu Ryūro e Uraomote (Frente e Verso, 1895) de Kawakami Bizan, pertencem ao primeiro tipo, e Yakō Junsa (Policial Noturno, 1895), de Izumi Kyōka (18731939), ao segundo. Em 1909, Kyōka instituiu, com outros colegas, a Bungei 
Kakushinkai (Associação de Renovação das Artes Literárias) que editava a revista Shinshōsetsu mas desapareceu sem fazer sucesso.

Além da Ken'yūsha, existiram outras corporações literárias, como a Min'yūsha, fundada em 1887 por Tokutomi Sohō (1863-1957), tendo a revista Kokumin no Tomo como órgão de publicação - que, em 1890, passou a editar o Jornal Kokumin. Essa corporação assumiu uma posição popular, defendendo a liberdade e a igualdade do indivíduo; na área literária, contribuiu para a apresentação da literatura estrangeira. Fizeram parte, entre outros, Uchida Roan (1868-1929), com Kure no Nijūhachinichi (O Final do Dia 28), e Tokutomi Roka (1868-1927), com Kokuchō (Cisne Negro, 1902). A revista encerrou-se em 1899.

A obra Maihime (A Dançarina), de Mori Ōgai (1862-1922), que acabara de retornar da Alemanha, é publicada na revista Komin no Tomo em 1890, anunciando o Romantismo com o protagonista Ōta Toyotarō, que apesar de amar a namorada Elise abandona-a por não querer abrir mão de suas pretensões sociais, diferentemente de Bunzō, de Ukigumo, que se desencanta com a vida quando suas idéias se chocam com a sociedade em que vive, perde a namorada para o amigo e acaba vivendo à margem da sociedade.

O Romantismo aparece expressando o ideal dos que despertaram para a individualidade dentro do desenvolvimento moderno do Japão. São seus representantes Kitamura Tōgoku (1868-1894), Shimazaki Tōson (1872-1943) e Doi Bansui (1871-1952) na poesia ocidental, Yosano Tekkan (1873-1935) e Yosano Akiko (1878-1942) na poesia tanka, ${ }^{2}$ e Kunikida Doppo (1871-1908) e Kyōka na prosa. O movimento romântico desenvolveu-se com base na revista Bungakukai, editada entre 1893 e 1898, que reuniu grande número de associados e colaboradores e deu chance a poetas jovens e angustiados de publicarem suas obras; idolatrando o belo e vivendo pelos ideais, caminhou para a tendência de valorização da arte pela arte.

Tōgoku tornou-se a figura central da revista Bungakukai depois de publicar Ensei Shika to Josei (O Poeta Pessimista e a Mulher, 1892) e fez duras críticas às contradições da modernização com Naibu Seimeiron (Tese sobre a Vida Interior, 
1893). Higuchi Ichiyō (1872-1896) foi uma das poucas escritoras que se destacou nesse período. Com base em sua própria experiência, retrata o sofrimento das mulheres diante das imposições da vida, revelando a falta de esperança e a resignação em obras como Jūsan'ya (Treze Noites, 1895) e Takekurabe (Medindo as Estaturas, 1895). Kyōka começou sua carreira como discípulo de Kōyō, mas depois despontou como romântico na obra Onna Keizu (Esquema da Linhagem Feminina, 1907), uma crítica ao sistema matrimonial japonês.

Mantiveram atividades literárias independentes nessa fase romântica alguns escritores, como Takayama Chogyū (1871-1902), que iniciou com o romance histórico e defendeu uma vida bela e sensual que satisfaz os instintos; Roka, autor de romances familiares, como Hototogisu (Rouxinol, 1898); e Doppo, que louvou a natureza de modo romântico em Musashino (Musashino, 1898).

Nos primeiros anos do século XX, o Naturalismo é introduzido no Japão e desenvolve-se com base no Romantismo japonês e sob influência da literatura naturalista da Europa, mas reflete, ao mesmo tempo, a situação social do Japão da época. De 1907 a 1911, assumiu o papel principal no círculo literário. As primeiras obras escritas na fase inicial, baseando-se no romance experimental de Zola, foram Hatsu Sugata (Primeira Silhueta, 1900) e Hayari Uta (Canção da Moda, 1902), de Kosugi Tengai (1865-1952), e Jigoku no Hana (Flores do Inferno, 1902), de Nagai Kafū, todas de 1902. Somente depois de aproximadamente cinco anos surge o Shizen Shugi — o Naturalismo japonês —, que extrai seu material da vida pessoal dos escritores. Apesar de manifestar uma visão social estreita, a consciência individual presente no Naturalismo japonês mostra um espírito moderno, cujos representantes, entre os escritores, são Tayama Katai (1871-1930) e Shimazaki Tōson. Na crítica, Shimamura Hōgetsu (1871-1918) foi defensor da literatura naturalista antes mesmo de Tōson e Katai tornarem-se famosos e foi graças a ele que a revista Waseda Bungaku se tornou o foco do Naturalismo.

${ }^{2}$ Tanka: forma poética japonesa constituída por 5 versos com, respectivamente, 5, 7, 5, 7 e 7 sílabas. 
Tayama Katai escreve Rokotsunaru byōsha (Uma Descrição Nua e Crua, 1904), afirmando que tudo precisa estar bem às claras, ser verdadeiro e natural; ${ }^{3} \mathrm{em}$ Futon (Acolchoado, 1907), ${ }^{4}$ o autor faz uma revelação de sua experiência amorosa, mostrando uma fase do desenvolvimento da literatura naturalista e, ao mesmo tempo, transformando-se num modelo da tendência do Romance do Eu. Em seguida, passa a defender um estilo objetivo que elimina a visão subjetiva do autor e a descrição psicológica das personagens, mas a tendência emotiva própria de Katai continua presente em Inaka Kyōshi (Professor do Interior, 1909), uma de suas obras mais representativas.

Shimazaki Tōson, ao trocar a poesia pela prosa, descreve a vida e a natureza em Chikumagawa no Sukecchi (Esboço do Rio Chikuma, 1911) e outras obras no estilo romântico, mas com Hakai (Quebra de Convenções, 1906) $)^{5}$ narra o sofrimento do protagonista interiorano sob o preconceito social discriminatório à casta dos Eta, da qual descendia seu protagonista, tentando ser fiel a si mesmo, tendo por cenário a paisagem de Shinshū. Com Haru (Primavera, 1908), porém, mostra uma forte tendência autobiográfica e descreve os sofrimentos que delineiam sua juventude, na época em que é um dos colaboradores da revista Bungakukai, e publica Ie (Família, 1913), em que descreve o declínio de uma família tradicional e de si próprio sob a pressão da família, avançando para uma literatura psicológica de auto-observação.

Contra essa tendência do Naturalismo japonês, conhecida como Han Shizen Shugi, estavam os escritores de grande instrução e conhecimento da chamada corrente Yoyū — Pródiga —, como Natsume Sōseki (1867-1916), que descreveu a

\footnotetext{
${ }^{3}$ Natural $($ em japonês shizen $=$ natureza $)$ : Nakamura Mitsuo esclarece que essa palavra é utilizada como sinônimo de "às claras" e de "verdadeiro" e como idéia oposta à ordem tradicional da sociedade.

${ }^{4}$ Futon: Nakamura Mitsuo concorda que ela inicia o Romance do Eu, em que o autor aparece diretamente na obra e faz confissões, tornando isso normal, pois considera que o movimento naturalista no Japão teve a mesma função que o Romantismo na Europa e que os autores da época, mesmo sem consciência, consideraram os românticos como pioneiros do naturalismo. Diz, ainda, que figuras principais do Naturalismo, como Tōson, Katai, Hōmei e Doppo, antes poetas românticos, complementaram seus trabalhos dando continuação como naturalistas, tendo por objetivo avançar em direção ao real.

${ }^{5}$ Hakai: Nakamura Mitsuo explica que essa obra, escrita em linguagem oral, segue as dicas de Crime e Castigo, usando como cenário Komoru, cidade interiorana onde viveu Tōson, e usa a personagem Segawa Otomatsu para confessar sua vida interior, da mesma forma que Doppo, que acreditava ser impossível criar uma personagem sem a confissão do autor. Nesse aspecto, observa-se muita transposição do autor, prenunciando um avanço rumo ao Romance do Eu.
} 
vida com uma atitude racional, focalizando o problema do egoísmo e da solidão do homem moderno; e Mori Ōgai, que abriu novos horizontes com o romance histórico, e Ishikawa Takuboku (1885-1912), ${ }^{6}$ que compôs o rigor da vida em seus poemas.

Após estudar na Inglaterra e lecionar na Universidade Imperial de Tóquio, Sōseki começou a trabalhar para o Jornal Asahi, em 1907. Assumindo a posição de escritor logo depois da guerra russo-japonesa, seus textos de caráter satírico e humorístico, de forte teor de justiça, como Botchan (Senhorzinho, 1906), refletiam bem a realidade cheia de contradições. Motivado pela situação do mundo, começa a passear com sabedoria nas esferas da imaginação e do surreal nas obras escritas entre 1905 e 1910 — de Rondontō (A Torre de Londres, 1905) a Mon (O Portão, 1910) —, que apresentam um recuo nos elementos satíricos e românticos e desenvolvem uma realidade obscura, focalizando a psicologia humana. Isso parece uma aproximação com o Naturalismo, mas contrapõe-se a ele pela adoção de uma temática que busca a ética.

Após a recuperação de uma úlcera estomacal, que quase lhe tira a vida aos 44 anos, Sōseki aprofunda sua visão artística e existencial e, entre 1912 e 1926, escreve obras como Higansugimade (Até o Final da Estação, 1912), Kōjin (Viajor, 1912), Kokoro (Sentimento, 1914), Michikusa (Desvios, 1915) e Meian (Claridade e Trevas, 1916, incompleta). Nessas obras, o escritor faz uma reflexão sobre os problemas do egocentrismo latente no caráter humano, os aspectos negativos do ego, entre eles a fealdade do egoísmo e do instinto e a infelicidade pelo excesso de autoconsciência. A maior parte dessas obras trata de casos de triângulo amoroso, mas são vazadas por uma aguçada inteligência e sentimento ético. Revela por inteiro a fealdade do ego e busca um estado elevado mediante a anulação do eu, uma sabedoria oriental baseada no termo "sokutenkyoshi". ${ }^{7}$ Esse era o tema de Meian, mas infelizmente Sōseki veio a falecer aos 50 anos, durante sua elaboração, mas deixou talentosos discípulos da chamda Corrente Yoyū.

Ōgai, após a fase romântica inicial escrevendo sobre a descrença em si e o vazio sentimental em Maihime, passa a escrever algumas obras como Ita sekusuarisu

\footnotetext{
${ }^{6} \mathrm{O}$ poeta pertencia à Jumoku to Kajitsu, uma das revistas que mantinham o desejo irreprimível de mudança dos movimentos democráticos e trabalhistas.
} 
(Vida Sexual, 1909), Seinen (Jovem, 1910) e Gan (Gansos Selvagens, 1911), que mostram uma aproximação com o Naturalismo japonês pela linguagem oral e pela descrição dos aspectos banais e desprezíveis da vida, mas que pela estrutura de composição racional de suas obras contrasta com o método naturalista de, normalmente, narrar os fatos numa seqüência temporal. Em 1909, Ōgai criou a revista Subaru e reuniu novatos como Kinoshita Mokutarō, Yoshii Isamu e Takamura Kōtarō que defendiam a chamada Corrente Kōtō (parnasiana). Continua suas atividades posteriores, escrevendo romances históricos, como Abe Ichizoku (O Clã Abe, 1913), Ōshio Heihachirō (Ōshio Heihachirō, 1914), Sanshō Dayū (Sanshō Dayū, 1915), Takasebune (O Barco do Rio Takase, 1916), e biografias, como Shibue Chūsai (Shibue Chūsai, 1916). Ōgai ultrapassa a visão humana naturalista e utiliza uma reflexão minuciosa baseada no caráter científico, desenvolvendo um estilo de exposição simples e elegante da descrição humana.

Surgiram também como movimentos de oposição à literatura naturalista a corrente estética Tanbi e a corrente idealista Shirakaba, que iniciaram suas atividades concomitantes à época do Naturalismo e continuaram a prosperar até o início da década de 1920, uma das épocas mais produtivas dentro do romance moderno.

A revista Kaizō, iniciada em abril de 1920 pelo empresário Yamamoto Sanehiko, lança os números: "Crítica do socialismo aos problemas trabalhistas", "Conquista do Capitalismo", "Pesquisa da Federação dos Sindicato dos Trabalhadores", "Reconstrução da mentalidade" e outras edições especiais, pedindo a colaboração de críticos sociais e também de estrangeiros, como Einstein, Weber, Rodin e Shaw, entre outros. A revista Chūō Kōron, já mais antiga, começa a entrar no mesmo ritmo e também a revista feminina Fujin Kōron, criada em 1919.

A corrente Shirakaba ocupou o cenário literário por volta de 1915, com uma visão de vida claramente oposta ao Naturalismo e baseada num pensamento idealista e humanista, que valoriza a individualidade e a natureza humana. O grupo surgiu em abril de 1910, com a revista de igual nome, instituída com a união de três revistas: Bōya (Campos de Aspirações), de autores como Mushanokōji Saneatsu (1885-1976), Shiga Naoya (1883-1971) e Kinoshita Rigen (1886-1925); Mugi (Trigo), liderada por

\footnotetext{
${ }^{7}$ Sokutenkyoshi: literalmente, seguir as leis divinas e anular a si mesmo.
} 
Satomi Ton (1888-1983); e Momozono (Pessegal), de Yanagi Muneyoshi (18891961), Koori Torahiko (1890-1924) e dos irmãos Arishima Takeo (1878-1923) e Arishima Ikuma (1882-1974).

Logo depois, aderiram ao grupo autores como Nagayo Yoshirō (1888-1961) e os artistas plásticos Kishida Ryūsei (1891-1929), Senge Motomaro (1888-1948) e Kurata Hyakuzō (1891-1943), entre outros. Recebeu ainda a colaboração de pintores como Takamura Kōtarō (1883-1965). Os componentes do grupo eram todos jovens na faixa de vinte a trinta anos, originários de Tóquio, e pertenciam à elite aristocrática e ao grupo economicamente dominante, o que lhes davam certa liberdade de atuação e pensamento, mas também eram atormentados pelas contradições ideológicas ao terem contato com o pensamento cristão, o espírito humanista e as questões sociais que contestavam o poder da classe a que pertenciam.

A visão de vida da Shirakaba objetivava a plenitude, a perfeição e o progresso do indivíduo, embasada pela crença absoluta de que o trabalho deles contribuiria para o aperfeiçoamento da vida das pessoas e o progresso da humanidade. Num primeiro momento, seus componentes fecharam os olhos à situação do Japão e dirigiram a atenção para o mundo, pensando em termos de humanidade, em virtude, inclusive, do contato com as pinturas e artes plásticas do Ocidente. $\mathrm{Na}$ paixão que os membros da corrente sentiam pelas artes, e especialmente pelo novo tipo de arte do Ocidente, estava o ponto em comum de seus filiados. Pois a Shirakaba, era, além de uma revista literária, uma revista de artes plásticas que reuniu vários artigos sobre Van Gogh, Matisse, Cézanne e Rembrandt, entre outros, editando seu famoso número especial sobre Rodin, de novembro de 1910, no qual se acha publicada uma carta de próprio punho de Rodin.

Mushanokōji e Yanagi pregavam o estabelecimento do pensamento de direita, da autoridade individual, e especialmente a consciência de que a nação é insignificante perante a grandiosidade do indivíduo. Em Nihon gendaishi taikei bungakushi (História da Literatura Japonesa na História Moderna do Japão, 1961), Odagiri Hideo diz que, em seus romances, Mushanokōji mostra o egocentrismo entrelaçado ao amor ao próximo. Situando-se em plena época da Primeira Guerra Mundial, escreve o drama Sono Imōto (Sua Irmã, 1914) e Aru Seinen no Yume 
(Sonho de um Jovem, 1916), opondo-se à guerra, clamando pela união do povo para promover mudanças no país e protestando contra a pressão desumana do governo japonês praticada na Ilha de Formosa em 1915. Esse seu pensamento humanista e contestador ao poder nacional, ao capitalismo e ao imperialismo foi direcionado para a construção de um pequeno local chamado Atarashiki Mura (Nova Vila), em 1918. Em setembro, adquire com recursos próprios uma área de cerca de $33 \mathrm{mil} \mathrm{m} \mathrm{m}^{2}$, em Hinata, na Província de Miyazaki. Dezenove companheiros da revista vão para o local, onde iniciam, em novembro, uma vida agrícola e artística, em busca de harmonia.

Enquanto esteve na vila, Mushanokōji desenvolveu intensa produção literária, escrevendo obras como Kōfukumono (Um Felizardo,1919), Aru Otoko (Um Certo Homem, 1921-23), Dai San Inja no Unmei (O Destino do Terceiro Ermitão, 192122), Yūjō (Amizade, 1919), Ningen Banzai (Viva aos Homens, 1922) e Aiyoku (Desejo Carnal, 1926). Mushanokōji, porém, começa, de fato, a deparar com os obstáculos para os quais os socialistas o alertaram, pois a vila deixa de funcionar por problemas financeiros.

Shiga Naoya é um autor que descreveu a luta contra as pressões que o indivíduo sofre em obras como Ōtsu Junkichi (Ōtsu Junkichi, 1912), Han no Hanzai (O Crime de Han, 1913) e Wakai (Reconciliação, 1917). Baseado em suas próprias vivências, escreveu Kinosaki nite (Em Kinosaki, 1917) e Takibi (Fogueira, 1920), retratando o ser humano e a natureza com uma postura harmoniosa. Seu único romance, An 'ya Kōro (Trajetória em Noite Escura, $1^{\circ}$ v., 1921, e $2^{\circ}$ v., 1937), é uma obra que descreve os sofrimentos de um protagonista que busca a harmonia com o ser humano na natureza.

Mais velho que muitos dos componentes do grupo Shirakaba, Arishima Takeo já estivera nos Estados Unidos e na Europa e lecionava na Escola Agrícola de Sapporo, em Hokkaidō, quando mudou-se para Tóquio em virtude da pneumonia de sua esposa, em 1914. Escreveu Osue no Shi (A Morte de Osue); no ano seguinte, Sengen (Declaração) e Samuson to Derira (Sansão e Dalila); em 1916, Dai Kōzui no Mae (Antes do Dilúvio). Nesse mesmo ano, perdeu a esposa e o pai e, livre dos laços familiares, publicou sucessivamente grandes obras, como Shi to Sono Zengo (A 
Morte e suas Proximidades, 1917), Jikken Shitsu (Laboratório, 1917), Meiro (Labirinto, 1915-18) e Umareizuru Nayami (Agonia Efervescente, 1918) até criar Aru on'na (Uma Mulher, 1911-19), uma de suas obras mais representativas, e Kain no Matsuei (O Último Descendente de Caim, 1918). Em 1923, Arishima Takeo suicida-se após dividir suas terras de Kaributo, ao norte do Japão, em Hokkaidō herdadas do pai, alto funcionário da Era Meiji — , entre os pequenos produtores da região, criando o Kaributo Kyōsei Nōdan (Grupo Agrícola de Convivência).

Satomi Ton, irmão mais novo de Arishima Takeo, publica sua primeira obra na Shirakaba de 1913, intitulada Kimi to Watashi to (Eu e Você). Em 1922, escreve Osoi Hatsukoi (Primeiro Amor Tardio), expressando a plenitude de seu sentimento e sua autoconfiança ao casar-se com uma gueixa que conhece em Ōsaka, contrariando a vontade dos pais. Mais tarde, amplia seus temas, antes centrados em si mesmo, e escreve obras como Ginsaburō no Kataude (Um Braço de Ginsaburō), de 1917, e San’nin no Deshi (Três Discípulos), do mesmo ano, desvendando a psicologia humana. O mesmo tipo de descrição psicológica também aparece em obras como Zenshin Akushin (Sentimentos Bons e Maus, 1916) e Tajō Busshin (Sentimento Búdico e Erótico, 1922).

O lado masculino e idealista da Shirakaba é mostrado por Nagayo Yoshirō, que descreveu tragédias de heróis em dramas, baseados numa forte paixão e senso de justiça. Como se pode ver na obra Takezawa Sensei (Professor Takezawa, 1924), tempos depois, passou a mostrar um estilo oriental de submissão à natureza.

A corrente Shirakaba perde rapidamente sua influência quando, a partir do final da Primeira Guerra Mundial, a situação econômica geral agrava-se e intensificam-se os movimentos trabalhistas e sociais. $\mathrm{O}$ grande terremoto da região Kantō, em 1923, assinalou o fim da revista Shirakaba, que atingiu 160 números, mantendo-se como a mais duradoura de todos os tempos no Japão. Em 1924, a revista Fuji é iniciada pelos antigos componentes da Shirakaba, como Nagayo Yoshirō, Mushanokōji, Shiga, Kurata Hyakuzō e Senge Motomaro.

Na mesma época da Shirakaba, surge a corrente estética Tanbi, que defende a voluptuosidade, o divertimento e o esteticismo. Representada por Kafū e Tanizaki 
Jun'ichirō (1886-1965), resultou na criação da revista Subaru, em janeiro de 1909, e das revistas Mita Bungaku e Shinshichō, em 1910.

Kafū enaltece o lado obscuro da vida nas obras Amerika Monogatari (Relatos sobre os Estados Unidos, 1908) e Furansu Monogatari (Relatos sobre a França, 1909), mostrando, ainda, uma tendência para o deleite e a sensualidade e para a valorização máxima da arte em Sumidagawa (Rio Sumida, 1909), Reishō (Sorriso Gelado, 1909) e Udekurabe (Jogo de Forças, 1916). Decepcionado com a realidade, Kafū passou a descrever os sentimentos e os costumes do mundo do meretrício de Edo, antiga Tóquio, em tom enaltecedor, mas com uma pincelada niilista. Após ter ocupado a cadeira de literatura da Universidade Keiō, fundou a revista Mita Bungaku, que se tornou uma das colunas da corrente Tanbi, juntamente com a revista Subaru.

Tanizaki representou, juntamente com Kafū, a literatura de valorização do belo e de entretenimento. Construiu sua literatura com um gosto peculiar, perspicaz e tenaz, de grande poder de estruturação e num estilo requintado. Shisei (Tatuagem, 1910), Kirin (Girafa, 1909), Chijin no Ai (Amor Insensato, 1934) e Sasame yuki (As irmãs Makioka) são suas obras mais representativas.

Nakamura Mitsuo diz que a corrente literária Tanbi foi considerada uma literatura boêmia, com suas críticas à civilização e aos moralistas, e que Tanizaki apresenta a personagem masculina como instrumento para realçar a beleza feminina, estando um passo à frente de Kafū, que considera a mulher como instrumento de prazer do homem. A literatura de Kafū e Tanizaki contrapõe-se ao Naturalismo numa atitude clara de deleite e valorização do belo, e mostra uma direção rumo à libertação dos sentidos.

Por volta de 1913, surge uma nova tendência literatura conhecida como Shin Genjitsu Shugi — Neo-Realismo — , da qual fizeram parte as correntes Shin Shichō - Nova Corrente de Pensamento - e Kiseki - Milagre —, que têm como característica a apresentação do problema apreendendo a feiúra e a pequenez do ser humano com um olhar racional de sua situação. A corrente Shin Shichō designa o grupo de escritores que fizeram parte da terceira e da quarta revista Shin Shichō. A terceira surgiu em fevereiro de , com a participação de Akutagawa Ryūnosuke (1892- 
1927), Kume Masao (1851-1952), Toyoshima Yoshio (1890-1955), Yamamoto Yūzō (1887-1974) e estudantes de literatura da Universidade de Tóquio, como Matsuoka Yuzuru, Sangū Makoto, Naruse Shōichi e Hata Toyokichi, mas ficou sendo conhecida apenas pelas obras de Toyoshima e Kume. A quarta revista foi iniciada em 1917 sob um movimento individualista e artístico, liderado por Akutagawa e Kikuchi Hiroshi (1888-1948), Kume, Naruse Shōichi e Matsuoka Yuzuru. A primeira revista Shin Shichō, de natureza artística e centrada no teatro, foi lançada em outubro de 1907 por Osanai Kaoru (1881-1928); a segunda foi composta em 1910 por Osanai, Tanizaki, o filósofo Watsuji Tetsurō e outras pessoas ligadas à Universidade de Tóquio, como Gotō Sueo, Imura Sōta e Koizumi Magane.

Akutagawa trata de naturezas humanas bastante diversas, tanto em narrativas históricas como contemporâneas, com grande habilidade técnica e aproveitamento dos clássicos. Escreveu obras como Rashōmon (Rashōmon, 1915), Hana (O Nariz, 1916) e Hanketi (O Lenço, 1916), e nos últimos anos de sua vida sua obra passa a expressar o mundo sem esperanças de forma mais direta, revelando uma realidade obscura, como a de Aru Ahō no Isshō (A Vida de um Tolo, 1927), que mostra uma vida que acaba em derrota, Haguruma (Roldanas, 1927), que descreve seu estado doentio pouco antes da morte, e Kappa (Kappa, 1927), que satiriza a triste realidade da vida, manifestando o espírito poético próprio desse autor, que se matou em 1927.

Kikuchi Hiroshi aborda temas fortes, centralizados no caráter humano, em narrativas históricas e contemporâneas, e produz dramas como Mumei Sakka no Nikki (Diário de um Escritor Desconhecido, 1919), Onshū no Kanata e Tōjūrōo no Koi (Além da Vingança e A paixão de Tōjurō, 1919).

A corrente Kiseki, criada em torno da revista Kiseki, posteriormente forma a corrente Shin Waseda, que, de certa maneira, segue o Naturalismo japonês, mas apresenta um idealismo e uma desconfiança nos aspectos obscuros da vida. Teve como representantes Uno Kōji (1891-1961), Kasai Zenzō (1887-1928), Hirotsu Kazuo (1891-1968), Kubota Mantarō (1889-1963), Satō Haruo (1892-1964), Murō Saisei (1889-1962) e Yamamoto Yūzō (1887-1974).

Em suas obras, Uno Kōji percorre um sentimento mundano e um humor próprio. As partes obscuras da vida são narradas em forma de quadros satíricos, em 
obras como Kura no Naka (No Depósito, 1919), Ku no Sekai (Mundo de Sofrimento, 1919) e Kareki no aru Fūkei (Paisagem com Árvores Secas, 1933).

Embora desesperançoso com a realidade e tendendo para o niilismo, há, na busca por um espírito humanista tenaz de Hirotsu Kazuo, um ritmo imutável em sua literatura, como em Shinkeibyō Jidai (Época de Doenças Psíquicas, 1917).

A vida suburbana de Tóquio e o mundo dos artistas que vivem sob os preceitos morais, o dever e o sentimentalismo, ao estilo antigo, são descritos por Kubota Mantarō com ar de admiração e amor em obras como Uragare (Plantas Secas, 1917) e Sabishikereba (Se Estiver Solitário, 1924).

Satō Haruo escreveu Den'en no Yūtsu (Plantações de Arroz Deprimentes, 1918) e Tokai no Yūtsu (Cidade Deprimente, 1922); Murō Saisei, a obra Sei ni mezameru koro (Tempo de Despertar para a Vida, 1919), na qual descreve a triste realidade perpassada por um espírito poético de forte teor selvagem, sensibilidade aguçada e amor humanitário.

Autor de Nami (Ondas, 1928), Yamamoto Yūzō desenvolve seus temas sob um sentimento de justiça social saudável, com muita elaboração e grande precisão descritiva.

As obras de Kasai Zenzō, como Kanashiki Chichi (Um Pai Desolado, 1912) e Ko o tsurete (Na Companhia das Crianças, 1918), representam a tendência de elaborar um espelho da vida real em uma situação extrema, mostrando a posição favorável do Romance do Eu nas duas primeiras décadas do século XX, escrito por muitos autores que expunham seu próprio sentimento e sua personalidade, tentando, assim, alcançar o leitor.

Com o crescimento dos movimentos sociais, a Literatura Proletária surge a partir de 1920, com as obras de Kobayashi Takiji (1903-1933) e Tokunaga Sunao (1899-1958). Em outubro de 1922, é criado o periódico Tanemakuhito, com acentuada característica cultural e didática que torna-se a força motora da literatura proletária e avança cada vez mais na descrição socialista, dando lugar a escritores como Maedagawa Kōichirō (1888-1957), com Santō Senkyaku (Navio de Terceira Classe, 1920), Hayama Yoshiki (1894-1945), com Umi ni ikuro hitobito (Pessoas que Vivem para o Mar, 1926) e Inbaifu (Meretriz, 1925),Kobayashi Takiji, com Kani 
Kōsen (Navio de Caranguejos, 1929), Tokunaga Sunao, com Taiyō no nai Machi (Cidade sem Sol, 1929), e críticos, como Hirabayashi Hatsunosuke (1892-1931), Aono Suekichi (1890-1961) e Kurahara Korehito (1902-).

No início da segunda década do século XIX, os jornais e revistas crescem e, com eles, a literatura de entretenimento voltada para a massa popular; após 1921, parte dos escritores liga-se ao jornalismo comercial crescente na época, adotando o romance de costumes ligado à vida moderna.

Em 1921, é realizada a primeira assembléia geral da Associação da Nova Mulher, e Hiratsuka Raichō (1886-1971) inicia a revista Seitō em meio à grande quantidade de outros periódicos mensais, como Kaizō, Bungei Shunjū, e também de semanários.

A revista Tanemakuhito é dissolvida em 1923, dando lugar a sua sucessora Bungei Sensen, criada em 1924, descortinando uma nova fase, e o surgimento espontâneo dos movimentos é substituído por um objetivo socialista consciente, como o da Federação Artística dos Anarquistas Japoneses (NAP) em 1929, em torno da revista Senki.

No cenário da crítica japonesa entre aproximadamente 1925 e 1935, surgem figuras marcantes como Kamei Katsuichirō (1907-1966) e Miki Kiyoshi (18971945), estes últimos, participantes ativos dos movimentos trabalhistas e socialistas que passaram pela experiência de serem presos.

Por volta de 1926, surge a literatura da corrente Shin Kankaku - Neosensorialista - , desenvolvida por um grupo de escritores que não pertenciam nem à literatura proletária nem à literatura de entretenimento voltada para a camada popular, como Yokomitsu Riichi (1898-1947), Kawabata Yasunari (1899-1972), Nakawa Yoichi (1897-1994) e Kataoka Teppei (1894-1944), com a revista Bungei Jidai (1924). Sua característica é representada pelas obras de Yokomitsu Riichi dessa época, como Hae (Mosca, 1923) e Nichirin (Halo solar, 1923).

Com a dissolução da corrente Neo-sensorialista, surge, em 1930, o chamada Clube da Corrente Modernista Shinkō Geijutsu - Artística Moderna —, formada por 32 escritores, centralizados em Ryūtan Jiyū e Nakamura Murao, que uniram as correntes Geijutsu - Artística —, clamando pela autonomia da arte e opondo-se ao 
Marxismo, ou seja, à literatura proletária. Seus principais membros foram Kawabata Yasunari, Kamura Isota, Ibuse Masuji, Kobayashi Hideo e Kajii Motojirō. Pregavam o marxismo, mas sem uma teoria artística em especial, tendendo mais para o americanismo comercial, o erotismo, o grotesco e o nonsense. Podemos citar, entre outras obras, Shanhai (Shangai, 1928-32), de Yokomitsu Riichi, e País das Neves (1935-7), de Kawabata; Sei kazoku (Família sagrada, 1930), de Hori Tatsuo (19041953), e a coletânea de prosas intitulada Seibutsugaku (Biologia, 1932), de Itō Sei (1905-1969), que apresenta a literatura neopsíquica, e outros autores, como Ibuse Masuji (1898-1993) e Kajii Motojirō (1901-1933).

Escritores veteranos, como Kafū, Tanizaki e Tōson, continuam a produzir sem mudança em seus estilos, mesmo em meio ao crescimento dessas correntes, e surgem novos escritores, como Maiko Shin'ichi (1895-1936), que iniciou com obras na linha do Romance do Eu, Takii Kōsaku (1894-1984) e a escritora Hayashi Fumiko (1903-1951), já reconhecidos pela crítica.

Por volta de 1930, como desmembramento da corrente Geijutsu, surge o Shin Shinri Shugi — Neopsicologismo — , que defendia o realismo psicológico tentando se aproximar ainda mais da realidade por meio da expressão da psicologia humana. Foram seus representantes Itō Sei e Hori Tatsuo, sendo que o primeiro tentou apreender a interioridade do ser humano por meio da técnica literária do fluxo de consciência e da confissão interior. Hori Tatsuo trabalhou com temas ligados à vida, à morte e ao amor em obras como Kaze Tachinu (Sem Vento, 1936); em Sei Kazoku (Família Sagrada, 1930), mostra aspectos psicológicos dos familiares e discípulos de um escritor falecido.

Com o aumento da pressão do governo militarista às ideologias de esquerda por volta de 1935, o grupo ligado à Literatura Proletária é encurralado e muitos de seus escritores mudam de postura, dando origem à chamada literatura de conversão, escritas no estilo do Romance do Eu. A prisão e morte de Kobayashi Takiji em 1933, a dissolução da Federação Cultural Proletária Japonesa e as declarações de conversão de líderes do Partido Comunista Japonês, feitas nas prisões, gera uma legião de “desertores" do movimento proletário. Na ocasião, surgem muitos escritores que abordam o tema, descrevendo o processo de abandono de suas ideologias, como é o 
caso da obra de Nakano Shigeharu (1902-1979) Mura no Ie (A casa da aldeia, 1935), que mostra, no sentimento do protagonista, o processo de conversão. Outros escritores representativos são Tokunaga Sunao (1899-1958), com Taiyō no Nai Machi (Cidade sem Sol, 1929), Shimaki Kensaku (1903-1945), com Seikatsu no Tankyū (A busca pela vida, 1937), Takeda Rintarō (1904-1946), com Nihon Sanmon Opera (Ópera Japonesa Barata, 1932), e Takami Jun (1907-1965), com Kokyū Wasureubeki (Não se Deve Esquecer a Terra Natal, 1935).

Por outro lado, apesar do iminente perigo da guerra, surge um período de restauração das artes e da literatura. Em 1935 são instituídos os Prêmios Akutagawa e Naoki de Literatura, fazendo surgir novos escritores, como Ishikawa Tatsuzō (1905-1985), Ishizaka Yōjirō (1900-1969), Niwa Fumio (1904-), Hōjō Tamio (19141937), Ishikawa Jun(1899-1986), Ozaki Kazuo (1899-1983), Nakayama Gishū (1900-1969) e a escritora Okamoto Kanoko (1899-1939), e críticos, como Kobayashi Hideo (1902-1983).

Nesse período, a literatura atuou em movimentos modernos na linha desenvolvida na Europa, ou em movimentos centralizados de lutas sociais e trabalhistas, mas todos com curta duração. Paralelamente a eles, autores já consagrados, como Kafū, Tanizaki, Shūsei, Tōson e Shiga, continuam suas atividades e também sob o clima adverso da guerra, quando a produção literária decai bastante. Nesse período, destacam-se ainda obras que, atendendo à política nacional, elogiavam a guerra, como Mugi to Heitai (O Trigo e o Soldado, 1938) de Hino Ashihei (1907-1960). Alheios a essa política, alguns escritores continuaram a manter acesa a chama da arte, como Itō Sei, com Tokunō Gorō no Seikatsu to Iken (A Vida e a Opinião de Tokunō Gorō, 1940); Hori Tatsuo, com Naoko, de 1941; Nakajima Atsushi (1909-1942), com Sangetsuki (Registros de Sangetsu, 1942). Também são dignos de menção Fugaku Hyakkei (As Cem Paisagens do Monte Fuji, 1939), de Dazai Osamu (1909-1948); e Sōbō (Todos os Povos, 1935), de Ishikawa Tatsuzō, que, em 1938, teve a obra Ikiteiru Heitai (Soldado Vivo, 1938) censurada e apreendida.

Com o término da Segunda Guerra Mundial, o mundo literário ganha nova vida com os escritores antigos, como Tanizaki, Shiga, Kafū, Kawabata, Nogami 
Yaeko (1885-1985), Mushanokōji e Ibuse, que voltam a atuar mediante solicitação dos jornais. Tanizaki publica As Irmãs Makioka (Sasameyuki) em 1943; Shiga escreve Haiiro no Tsuki (Lua Cinzenta, 1946); Kafū, Kunshō (Condecoração, 1946); e Kawabata, Nuvem de Pássaros (Senba Zuru, 1949). Reiniciam, também, suas atividades os ex-escritores da linha proletária, representados por Miyamoto Yuriko (1899-1951), Tokunaga Sunao e Nakano Shigeharu, que criam a revista Shin Nihon Bungaku em 1946 e fundam a Associação Shin Nihon Bungaku, visando à literatura democrática. No âmbito da crítica, surgem Odagiri Hideo (1916- ), Hirano Ken (1907-1978), Ara Masahito e Sasaki Kiichi (1914-1993), que publicam a revista Kindai Bungaku, em que foram expostas diferentes visões sobre a literatura e a política.

Paralelamente, despontam novos escritores que compõem a corrente Shin Gesaku — Neodramática —, também conhecida como corrente Burai — Libertina —, que descreveram a oposição à antiga moral e o desespero diante da vida por meio do autoflagelo e da sátira: Ishikawa Jun, com Yakeato no Iesu (Jesus após o Incêndio, 1946); Sakaguchi Ango (1906-1955), com Daraku Ron (Tese da Ruína, 1946); Oda Sakunosuke (1913-1947), com Doyō Fujin (Senhora Sábado); e Dazai Osamu, com Pôr-do-Sol, de 1946.

Surge, ainda, o grupo conhecido como Dai Ichiji Sengoha - Primeira Corrente Pós-Guerra - , que inicia suas atividades literárias centralizadas na revista Kindai bungaku (1946), com os autores Noma Hiroshi (1915-1991), com Kurai E (Pintura Triste, 1946), e Shiina Rinzō (1911-1973), com Eien naru Joshō (Prefácio para a Eternidade, 1947), seguidos por Umezaki Haruo (1915-1965), com Sakura Jima (Ilha Sakura, 1946); Nakamura Shin'ichirō (1918-), com Shi no Kage no Moto (Sob a sombra da Morte, 1946); Takeda Taijun (1912-1976), com Mamushi no Sue (O Fim da Serpente, 1947); Ōka Shōhei (1909-1988), com Furyoki (Registro de um Prisioneiro de Guerra, 1948); e Mishima Yukio (1929-1970), com Confissões de uma Máscara, de 1949, seguidos logo depois pelo grupo Dai Niji Sengoha Segunda Corrente Pós-Guerra —, composto por Hotta Yoshie (1918-), Abe Kōbō (1924-1993) e Shimao Toshio (1917-1986). Com a expansão do folhetim, Inoue Yasushi (1907-1991), Niwa Fumio, Funahashi Seiichi (1904-1976), Ishikawa 
Tatsuzō e Hayashi Fumiko mostram um trabalho intenso na descrição dos costumes e em obras que atendem ao gosto literário do público.

Com o período estável de pós-guerra e a vida tornando-se mais tranqüila, na literatura, surge uma tendência de buscar as matérias no cotidiano, representada pelo grupo conhecido como Dai San no Shinjin - Terceira Nova Geração - , composto por escritores como Yasuoka Shōtarō (1920-), com Warui Nakama (Más Influências, 1953); Yoshiyuki Jun'nosuke (1924-1994), com Shūu (Chuva Repentina, 1954); Shōno Junzō (1921-), com Puuru Saído Shōkei (Pequena Paisagem ao Lado da Piscina, 1954); Endō Shūsaku (1923-), com Shiroi Hito (Os Brancos, 1955); e Agawa Hiroyuki (1920-), com Kumo no Bohyō (Lápide de Nuvem, 1953). Nessa época, os nomes principais da crítica literária são Fukuda Tsuneari (1912- ), que foi contra a idéia de unir a política e a literatura, e Katō Shūichi (1919-1987), que escreveu 1946 Bungakuteki Kōsatsu (Considerações Literárias de1946) e propõe uma nova visão da história da literatura com Nihon Bungakushi Josetsu (Introdução à História da Literatura Japonesa, 1975).

Após 1955, o Japão entra no período de grande crescimento econômico, e a literatura mostra indícios de pôr um fim às lembranças da guerra, com Taiyō no Kisetsu (Estação do Sol, 1955), de Ishihara Shintarō (1932-). Surgem escritores que demonstram interesse pelas questões políticas e sociais, como Ooe Kenzaburō (1935), com Shisha no Ogori (Presente dos Mortos, 1957); Kaikō Takeshi (1930-1989), com Hadaka no Ōsama (O Rei Nu, 1957); Kita Morio (1927-), com Dokutoru Manbō Kōkaiki (Travessia Marítima do Dr. Manbō, 1960); e Miura Tetsuo (1931-), com Shinobu Kawa (Rio Shinobu, 1960).

Nesse período, há um florescimento da literatura feminina, com a atuação de escritoras como Enji Fumiko (1905-1986), Kōda Aya (1904-1990), Uno Chiyo (1897-1996), Mukōda Kuniko (1929-1981), Ariyoshi Sawako (1931-1984), Kōno Taeko (1926-), Ooba Minako (1930-), Hayashi Kyōko (1930-), Sono Ayako (1931-), Takahashi Takako (1932- ), Tomioka Taeko (1935-) e Kurahashi Yumiko (1935-).

Assinalamos, nessa época, a atuação de críticos como Nakamura Mitsuo (1911-1988), Karaki Junzō (1904-1980), Fukuda Tsuneari, Katō Shūichi, Yoshida 
Ken'ichi (1912-1977), Yamamoto Kenkichi (1907-1988) Yamazaki Masakazu (1934-), Toyama Shigehiko (1923-), Ooka Makoto (1931-) e Etō Jun (1933-).

Após 1965, os escritores do pós-guerra continuam suas atividades ao lado de uma geração intimista, representada por Furui Yoshikichi (1937-) e Ogawa Kunio (1927-). Os grandes escritores continuam a produzir obras, publicadas sucessivamente ao lado de novos escritores, como Inoue Hisashi (1934-), que recebeu o Prêmio Naoki em 1972 com a obra Tegusari Shinjū (Suicídio por Amor de Punhos Aconrrentados); Nakagami Kenji (1946-1992), laureado com o Prêmio Akutagawa de 1975 com Misaki (Promontório); Murakami Ryū (1952-), que despontou com o Prêmio Akutagawa de 1976 com Azul Quase Transparente; Murakami Haruki (1949-), que iniciou a carreira com Kaze no Uta o Kike (Ouça o Som do Vento), agraciado com o Prêmio de Estreante Gunzō em 1979 e best-seller com Noruee no Mori (A Floresta de Norwegian); Shiina Makoto (1944-), que consolidou a carreira literária com Inu no Keifu (Linhagem dos Cães), obra que lhe deu o Prêmio Yoshikawa Eiji na categoria de estreante em 1988; Yoshimoto Banana (1964-), ganhadora de diversos prêmios de literatura com a obra Kitchin de 1987 e com Tugumi, de 1989; e Yamada Eimi (1959-), que teve uma estréia brilhante com Bed Time AIDS e recebeu o Prêmio Naoki de 1987 com Soul Music Lovers Only. 
De Katai a Dazai: Apontamentos para uma Morfologia do Romance do Eu Anexo

ANEXO

Imagem 1 - Prímulas
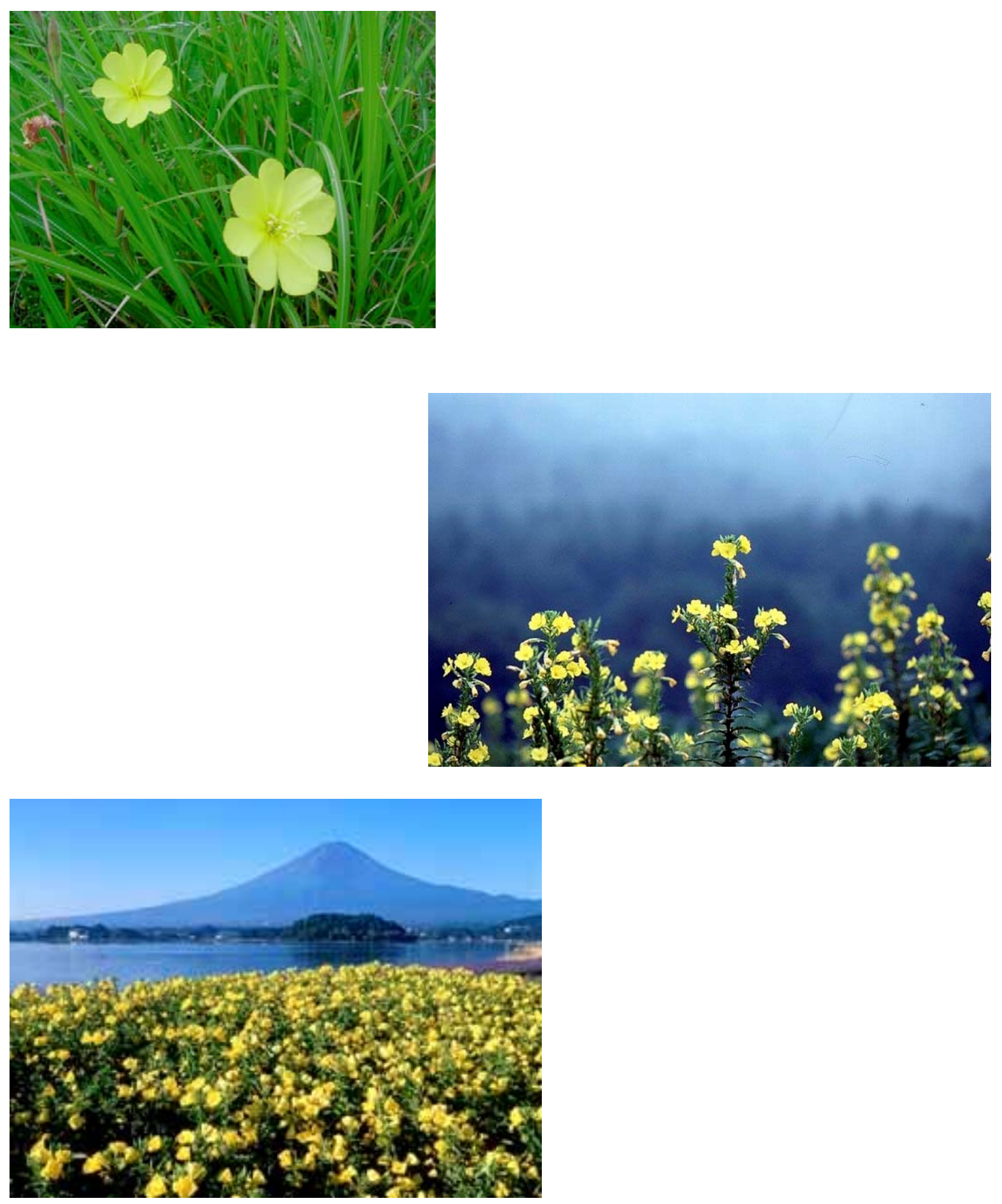

Monte Fuji com as prímulas 
De Katai a Dazai: Apontamentos para uma Morfologia do Romance do Eu Anexo

ANEXO

Imagem 2 - Yūgao
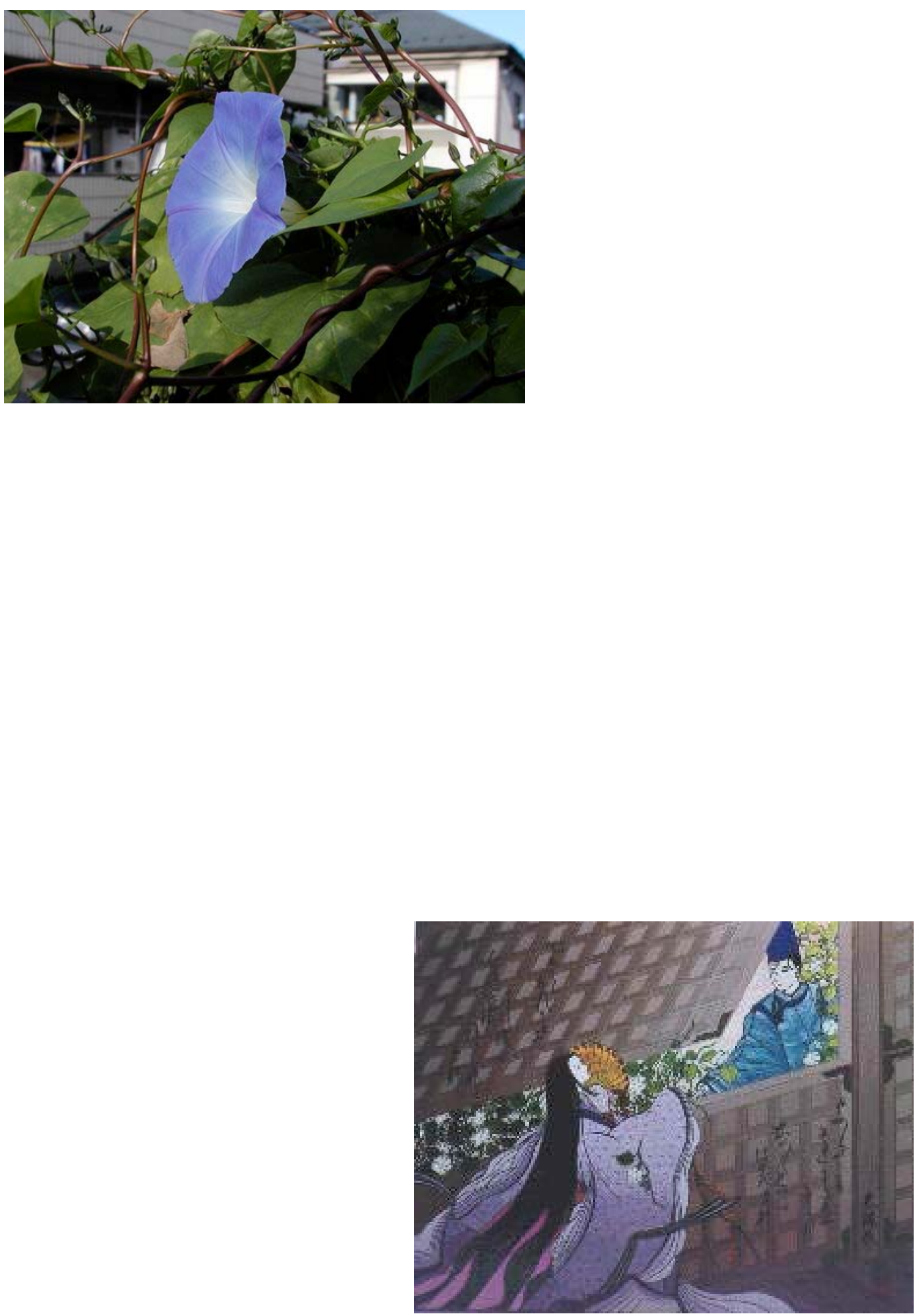
De Katai a Dazai: Apontamentos para uma Morfologia do Romance do Eu Anexo

Yūgao e Hikaru Genji 
De Katai a Dazai: Apontamentos para uma Morfologia do Romance do Eu Anexos

ANEXO

Imagem 3 - Tomoe

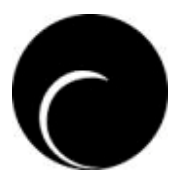

Um tomoe

esquerda

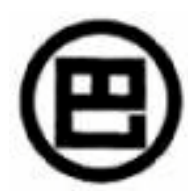

Ideograma tomoe

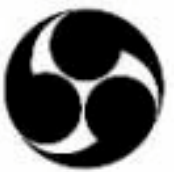

Três tomoe

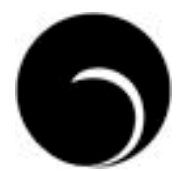

Um tomoe

direita

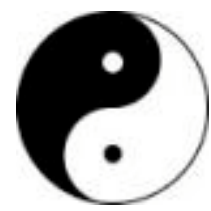

Tomoe

Negativo e Positivo

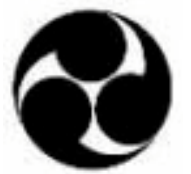

Três tomoe 